\title{
A REVISION OF THE ANNUAL SPECIES OF CHORIZANTHE (POLYGONACEAE: ERIOGONOIDEAE)
}

\author{
JAMES L. REVEAL \\ Department of Botany, University of Maryland, \\ College Park, Maryland 20742-5815
}

AND

Clare B. Hardham

4485 Creston Road

Paso Robles, California 93446-9804

\begin{abstract}
The annual species of Chorizanthe were last revised in 1884 by Parry who accounted for 29 species in a broadly defined genus. All but one of these species was found in North America. The North American species of Chorizanthe were last reviewed in 1934 by Goodman who defined the genus more narrowly but still discussed a total of 40 species. In the fifty-five years since that review, only four new species have been discovered, although several considered distinct by Goodman have been reduced to synonymy. The current revision recognizes 40 species in North America, all but seven found in California. Like Goodman, the present revision continues to exclude such closely related genera as Mucronea and Centrostegia. Unlike Parry and Goodman, we maintain the genus Lastarriaea as a distinct genus but Eriogonella and Acanthogonum, recognized by Goodman, are returned to Chorizanthe. Several new superspecific names are proposed. The subg. Chorizanthe, typified by $C$. virgata Benth., is a taxon of about ten perennial species restricted to Chile; it is not treated here. Three additional and newly established subgenera are proposed: subg. Quintaria (for C. spinosa) and subg. Eriogonella (for C. membranacea) are both monospecific while the subg. Amphietes (typified by $C$. douglasii) is reserved for the bulk of the annual species. Within the subg. Amphietes, besides the sect. Herbaceae (lectotypified on $C$. douglasii) and sect. Acanthogonum (based on C. rigida), two new sections are established: Fragile (typified by $C$. brevicomu) and Clastoscapa (for C. interposita). Two new subsections are established in the sect. Herbaceae, namely the subsect. Legnota (typified by $C$. douglasii) and the subsect. Petasata (typified by $C$. palmeri). Three new monospecific subsections are proposed in the sect. Acanthogonum (typified by C. rigida): Parvatia (for C. polygonoides), Exolophyta (for C. clevelandii) and Ansata (for $C$. watsonii). A section proposed by Parry, Chorizanthella, is reduced to the subsectional rank in Acanthogonum; it is lectotypified by $C$. corrugata. Two new varieties are described: $C$. pungens var. hartwegiana and $C$. biloba var. immemora. Each species is described, its type and appropriate nomenclatural and taxonomic synonymy indicated, and the taxa are discussed as appropriate. Representative specimens are cited and the geographic distribution of each species summarized.
\end{abstract}

KEY WORDS: Polygonaceae, taxonomy, Chorizanthe, Acanthogonum, Eriogonella, California, México, Perú, Chile. 


\section{INTRODUCTION}

In 1934, George Goodman published his doctoral dissertation on the North American species of Chorizanthe in the Annals of the Missouri Botanical Garden. His paper appeared fifty years after Parry's (1884) review of the annual species. Parry's remarks followed closely on those presented by Watson (1877) and Torrey and Gray (1870). The genus as a whole was last revised by Bentham (1856) who proposed the taxon (Bentham 1836). Although the number of known North American species in the genus grew significantly from 1836 to 1934, expanding from the four proposed by Bentham to the 40 recognized by Goodman nearly a century later, only four new species have been found in North American since 1934 (Goodman 1939; Wiggins 1940; Hardham 1964; Reveal 1989a).

The history of Chorizanthe is replete with questions regarding its circumscription. The debate has centered around what genera should or should not be excluded from it. Bentham (1836) proposed Mucronea and maintained it twenty years later in his review for the Prodromus. At that time he published Centrostegia for Asa Gray, and a year later, John Torrey (1857) established Acanthogonum. It was Gray (1859) who first began to expand Chorizanthe for in that year he reduced Mucronea to it when he described Chorizanthe perfoliata. This concept was continued when he and Torrey (1870) further expanded the concept of Chorizanthe by including not only Mucronea but Acanthogonum as well. In 1877, Watson carried the process one step further by reducing Centrostegia to synonymy under Chorizanthe.

The genus Lastarriaea was initially established for a South American annual, L. chilensis (Rémy 1851-1852). Nuttall had found the genus in California in the 1830s, recognized its uniqueness, and proposed at least two generic names for his material, neither of which was published (Parry 1885). Initially the relationship of Lastarriaea to the rest of the tribe Eriogoneae was unclear, and Bentham (1856) was unable to place the genus. When Torrey and Gray (1870) considered it, they placed Lastarriaea after Chorizanthe, but considered the California specimens to have been introduced from Chile. Parry (1884) finally referred Lastarriaea to Chorizanthe, a point he (Parry 1885) substantiated the following year when he examined specimens of Lastarriaea in the British Museum (Natural History) and in the Royal Botanic Garden at Kew.

Thus it was that a half century after Chorizanthe had been proposed, and a series of related genera established, that all of them had been submerged. It was at this point in the history of the group that the major modern floras of California, where the majority of North American species occur, were started. Jepson (1913) followed Watson's definition of Chorizanthe, including within it all of the segregate genera except Lastarriaea. And like Torrey and Gray (1870), Jepson also considered the California material of the latter genus to be naturalized from Chile. Even after the appearance of Goodman's monograph, Abrams (1944) continued to circumscribe Chorizanthe as Jepson had done before him, maintaining Lastarriaea even though Goodman (1934) had included it in Chorizanthe. Abrams was a bit more cautious, however, stating that Lastarriaea was "probably" introduced into California.

In Goodman's (1934) revision, he circumscribed Chorizanthe to include Lastarriaea, but excluded Mucronea, Acanthogonum and Centrostegia. Furthermore, one species usually placed in Centrostegia, C. insignis, was referred to Oxytheca, a genus most closely related to Eriogonum. As defined by Goodman, Chorizanthe was characterized by the presence of a straight rather than a curved embryo. Accordingly, he excluded two additional species ( $C$. membranacea and C. spinosa) of Chorizanthe with curved embryos, erecting Eriogonella to receive them. 
When Munz (1959) prepared his treatment of Chorizanthe for the California flora, he closely followed that of Jepson (1913) and Abrams (1944), but accepted Goodman's recommendation to include Lastarriaea in Chorizanthe.

The present treatment returns, at least in part, to the concepts formulated by Bentham (1856). We propose to maintain Mucronea and Centrostegia as distinct genera, the former to include $M$. californica and $M$. perfoliata, and the latter restricted to $C$. thurberi. The three remaining species often associated with Centrostegia have each been placed in a monospecific genus (Reveal \& Hardham 1989): Aristocapsa for C. insignis, Systenotheca for C. vortreidei and Dodecahema for C. leptoceras. Lastarriaea is also maintained and defined to include three species: L. chilensis of Chile, L. coriacea of California and northern Baja California and L. ptilota, a new species from central Baja California, México (Reveal 1989b). Like other authors, we do not consider Eriogonella to be a defensible genus. The difference between Acanthogonum and Chorizanthe is slight, even as circumscribed by Goodman $(1934,1955)$, the former having 3-toothed (rather than 6-toothed) involucres, an occasional involucre with two flowers, and stamens inserted faucially on the tepals rather than basally on the receptacle as is typical in the latter. Like Torrey and Gray (1870), we are unable to recognize the genus based solely on these features.

\section{TAXONOMY}

Chorizanthe R. Br. ex Benth., Trans. Linn. Soc. London 17: 416. 1836.-LeCTOTYPE: Chorizanthe virgata Benth., selected by Goodman, Ann. Missouri Bot. Gard. 21: 19. 1934.

Acanthogonum Torr. in Whipple, Pacif. Railr. Rep. Whipple, Bot. 4: 132. 1857.-TyPE: Acanthogonum rigidum Torr. in Whipple.

Eriogonella Goodman, Ann. Missouri Bot. Gard. 21: 90. 1934.-TYPE: Eriogonella membranacea (Benth.) Goodman.

Spreading to erect, glabrous, glandular or pubescent annual (ours) or perennial herbs and subshrubs arising from a slender to stout taproot or branched, woody caudex; leaves basal or basal and cauline, sometimes sheathing up the stem, linear to oblanceolate or spatulate, glabrous to pubescent, tapering to an indistinctly winged or more often to a slender petiole; flowering stems prostrate to erect; branches open and spreading or erect, typically trichotomously branched at the first node, otherwise dichotomous throughout; inflorescences cymose, capitate or uniparous due to the suppression of the secondaries in the dichotomous branching pattern; bracts entire, mostly 2 and opposite, foliaceous to subulate or linear, sometimes numerous and arranged in whorls, mostly erect or at most merely spreading; peduncles lacking; involucres cylindrical to urceolate or turbinate to campanulate, the lobes 3,5 or 6 and 3-6 ribbed, terminated by 3,5 or 6 awns, these usually uncinate and spreading, often with the anterior tooth and awn more pronounced than the others or in two distinct sets of three with the anterior set often the longest, infrequently the reduced ribs without obvious teeth; flowers solitary or rarely 2, white to yellow or pink to rose-pink or red, cylindrical to campanulate, glabrous or pubescent without, the tepals 6, petaloid, entire or cleft to variously fringed, sometimes toothed or cuspidate, united basally to nearly two-thirds of their length; stamens 9,6 or 3 , or variously $3-9$, exserted to included, the filaments glabrous and free or ciliate-pilose and united basally into a short staminal tube, basal or variously attached on the united portion of the floral tube, the anthers oval to oblong, cream to white or yellow, or more commonly maroon to red; achenes light to dark brown or black, glabrous, the narrow base tapering gradually to a slightly narrower, 3-angled beak with a straight embryo, rarely 
with a globose base tapering abruptly to a distinctly 3-angled beak and a curved embryo, in abundant endosperm; $n=$ (18) 19-21 (24), (38) 40 (45).

A genus of about 50 species, the annuals (41 species) found primarily in North America from Washington, Oregon and Idaho southward through California, Nevada, western Utah and western Arizona in the United States to northwestern Sonora and central peninsular Baja California, México, with a single annual widespread in South America from extreme southern Perú southward to central Chile, and the approximately ten perennial species restricted to the arid regions of central and northern Chile.

Our review of Chorizanthe (from the Greek chorizo, to divide, and anthos, flower, alluding to the tepals that are united half or more the length of the perianth) is primarily a classical one based on field and herbarium studies. To this end we have individually and jointly collected specimens throughout the range of the genus in North America and had hoped to conduct field work on the perennial members confined to South America as well so that a complete revision of the genus might be attempted. The genus was last revised in its entirety by Bentham (1856) and the relationship of the perennial species to certain groups in Eriogonum is fundamental to our understanding of the entire subfamily.

Our individual efforts in the field extend over three decades but nearly always as a secondary matter. Our work on Eriogonum (JLR) and Monardella (CBH) has provided us opportunities to collect Chorizanthe and its near relatives, although for over a decade (1954-1964), Hardham concentrated more on Chorizanthe than any other genus. Our joint field work has been restricted mainly to the Coast Ranges of central California during the field seasons of 1987 and 1988 where we collected about 20 numbers of Chorizanthe. Alone Hardham has made about 140 collections of Chorizanthe while Reveal has made some 210, the majority gathered in 1987 and 1988.

Long-term cytological studies of the genus by Hardham (1989) disclosed a complex array of aneuploid and polyploid levels not unlike that found in the annual species of the subgenus Oregonium in Eriogonum (Shields \& Reveal 1988) except that it is within the species in Chorizanthe rather than between species as is the case in Eriogonum. We attempted to determine the relations among the annual species of Chorizanthe using cladistical methods to evaluate the characters of the species, but without a detailed study of the South American perennials, our efforts were incomplete and not wholly valid. What we were able to show were the general relationships within individual species complexes and this has aided us in defining groups.

The herbarium investigations have been greatly aided by the computer facilities provided by the Norton-Brown Herbarium at the University of Maryland. An inhouse multi-user, multitasking Alpha Micro Model 1082 super-microcomputer has been used throughout our study. When visiting other herbaria, we used a PC's Limited 286 personal computer. On both computers the database management software used was Cuadra Associates' STAR system, an extremely powerful text-based tool. In this fashion we have been able to keep detailed, searchable records on the more than 20,000 sheets representing some 6800 individual collections of Chorizanthe that we have seen.

Using the same computer system at College Park, and Piicion Lazortype software, we have been able to prepare camera-ready copy of the papers which make up portions of this issue of Phytologia.

The following treatment attempts to summarize our current understanding of the systematics of the genus Chorizanthe. We provide an artifical key to the species plus individual keys to the subgenera, sections and subsections that we have recognized. Each species is described, its known geographic distribution is outlined, and its nomenclature is reviewed. A 
list of representative specimens provides a statement of our concept of the taxon and each entity is discussed as appropriate. We would like to encourage others to collect specimens of Chorizanthe, especially from areas at the known edges of the species. The need for a study of the South American perennials has not lessened even though regarded as not significant by those who control the ultimate fate of systematic research in this nation. In the United States, we are particularly concerned about several species near the Pacific coast that either have not been collected in recent decades or are now known only from a few populations. Unlike Eriogonum species which generally thrive in disturbed habitats, the vast majority of species in Chorizanthe do not, and in fact tend to be extirpated in such sites. If our study has done nothing else it has shown us how sensitive species of this genus are to the activities of man.

\section{Key to the Species}

A. Involucres 6-toothed (sometimes obsolete) or 6-ribbed.

B. Involucral awns 6 and equal or of two sizes with the longer awns alternating with the distinct but generally shorter awns, often with the anterior tooth the longest and most distinct.

C. Teeth of the involucre without a scarious or membranaceous margin.

D. Involucral teeth equal or of alternating lengths but the anterior tooth not greatly elongated.

E. Tepals entire, cuspidate or erose, not fimbriate or bilobed.

F. Tepals all of the same width and length.

G. Plants erect; stems disarticulating at the nodes; stamens 3, attached faucially at the top of the flower tube; desert plants.

H. Involucral tubes not ventricose basally, thinly pubescent; plants of North American deserts. ........................................................... 39. C. brevicornu

$\mathrm{HH}$. Involucral tubes ventricose basally, densely pubescent; plants of South American deserts. .................................................... 40. C. commissuralis

GG. Plants prostrate to ascending or erect; stems not disarticulating at the nodes; stamens 3-9, attached on the receptacle; coastal or southern montane plants.

H. Tepals erose or cuspidate; flowers $2-3 \mathrm{~mm}$ long, white; plants densely pubescent, tannish; filaments free; Santa Barbara Co. northward.

I. Tepals erose apically; flowers only slightly exserted; San Luis Obispo and Santa Barbara cos.

7. C. angustifolia

II. Tepals cuspidate apically, flowers well exserted; San Francisco Peninsula from San Mateo Co. northward to Marin and Sonoma cos.

8. C. cuspidata

HH. Tepals entire; flowers 2-5 mm long, white, yellow or bicolored with white or pink to rose lobes; Ventura Co. southward.

I. Plants yellow-green; flowers white or yellow; involucral tubes $1.5-3 \mathrm{~mm}$ long, the awns uncinate; filaments united basally into a short pilose tube; eastern Ventura to San Bernardino cos., California, south to San Quintín, Baja California.

22. C. procumbens

II. Plants reddish; flowers bicolored, the tube yellowish, the lobes rose to pink; involucral tubes $2.5-5 \mathrm{~mm}$ long, the awns straight apically; filaments free; Baja California from San Quintín south.

J. Flowers 4-5 mm long; filaments 2-2.5 mm long; achenes $2.5-3 \mathrm{~mm}$ long; mesas and hills east of the coast in the San Quintin area south to east of El Rosario. 28. C. turbinata

JJ. Flowers (6) 7-9 mm long; filaments 4-6 mm long, achenes 3.5-4 $\mathrm{mm}$ long; Sierra San Borja.

29. C. mutabilis

FF. Tepals unlike, the inner ones usually narrow and definitely much shorter than the outer ones.

G. Flowers monocolored, white to pink or rose; involucral awns \pm the same size.

H. Involucral awns straight; tepals entire or erose apically.

I. Plants erect; involucres 3-4 (4.5) mm long; plants of Sonoma and Marin cos.

11. C. valida 
II. Plants decumbent; plants of Los Angeles Co. south.

J. Awns 1-1.5 mm long, rare and probably extinct, Los Angeles and Orange cos. 20. C. parryi

JJ. Awns 1.5-3 mm long; local and common in Baja California from near Colonet to near San Quintín. 21. C. inequalis

HI. Involucral awns uncinate; tepals entire or sometimes erose apically.

I. Plants grayish and strigose; involucral tubes $1.5-2 \mathrm{~mm}$ long; flats, foothills and higher slopes in and near the San Gabriel, San Bernardino and San Jacinto mountains. 20. C. parryi

II. Plants thinly pubescent, reddish or greenish; involucral tubes $2.5-6 \mathrm{~mm}$ long.

J. Lower foliaceous bracts soon deciduous or lacking.

K. Flowers 3-4 (5) $\mathrm{mm}$ long, mostly included; involucres clustered; Monterey Co. south to coastal San Diego Co. eastward to western San Bernardino Co. 23. C. staticoides

$\mathrm{KK}$. Flowers $4.5-6 \mathrm{~mm}$ long, long exserted; involucres solitary; montane Riverside and San Diego cos. south to extreme northern Baja California.

24. C. leptotheca

JJ. Lower foliaceous bracts persistent.

$\mathrm{K}$. Flowers 4.5-6 mm long, long exserted; involucral tubes 3-4.5 $\mathrm{mm}$ long, pubescent with slender hairs; non-serpentine; southern Coast Ranges and Sierra Nevada from Monterey and Merced Co. south to northern Riverside Co. ... 25. C. xantii

KK. Flowers $2.5-3.5 \mathrm{~mm}$ long, slightly exserted.

L. Flowers $3-3.5 \mathrm{~mm}$ long; involucres $2.5-3 \mathrm{~mm}$ long, pubescent with slender hairs; stamens 9; serpentine; San Luis Obispo Co. 26. C. breweri

LL. Flowers 2.5-3 mm long; involucres 2-2.5 mm long, pubescent with stout hairs; stamens 6; restricted to Santa Cruz and Santa Rosa islands, Santa Barbara Co.

27. C. wheeleri

GG. Flowers bicolored, the tube yellow, the lobes pink to rose; involucral awns of two size classes, often with the shorter alternating ones nearly obsolete.

H. Flowers $4-5 \mathrm{~mm}$ long; filaments $2-2.5 \mathrm{~mm}$ long; achenes $2.5-3 \mathrm{~mm}$ long; mesas and hills east of the coast in the San Quintín area south to east of El Rosario. 28. C. turbinate

HH. Flowers (6) 7-9 mm long; filaments $4-6 \mathrm{~mm}$ long; achenes $3.5-4 \mathrm{~mm}$ long; Sierra San Borja. 29. C. mutabilis

EE. Tepals, at least the inner, fimbriate or bilobed.

F. Outer tepals entire or erose to variously lobed; plants of central California.

G. Flowers with rose, maroon or dark purple lobes.

H. Outer tepals entire, erect; flowers $4-5 \mathrm{~mm}$ long; involucral tubes $3.5-4 \mathrm{~mm}$ long; awns 0.5-1 mm long, usually uncinate; serpentine; Santa Lucia Mountains, Monterey and San Luis Obispo cos. 12. C. palmeri

HH. Outer tepals emarginate to bilobed or erose, spreading to recurved.

I. Outer tepals emarginate or deeply bilobed, the inner not bilobed; flowers (4.5) 5-6 mm long, involucres 4-6 mm long, slightly ventricose basally, the awns $0.5-1.5 \mathrm{~mm}$ long; plants of non-serpentine soils in Monterey and San Benito cos. south to San Luis Obispo and Fresno $\cos$.

13. C. biloba

II. Outer tepals erose, the inner bilobed and fimbriate; flowers $4-4.5 \mathrm{~mm}$ long, involucres $4-4.5 \mathrm{~mm}$ long, strongly ventricose, the awns $0.5-2 \mathrm{~mm}$ long; plants of serpentine soils in eastern Monterey and San Benito south to eastern San Luis Obispo and adjacent Fresno cos.

14. C. ventricosa

GG. Flowers with white lobes.

H. Inner tepals fimbriate; flowers $4-4.5$ (5) $\mathrm{mm}$ long; plants reddish or greenish; Monterey to Santa Barbara Co. 15. C. obovata 
HII. Inner tepals bilobed; flowers 5-6 mm long; plants yellowish-green; Sierra Madre Mountains, Santa Barbara cos. 16. C. blakleyi

FF. Outer and inner tepals fimbriate; plants of southern California and México.

G. Plants not glandular, flowers $4.5-6 \mathrm{~mm}$ long, glabrous; involucral tubes $3-4 \mathrm{~mm}$ long; central Baja California Norte.

30. C. rosulenta

GG. Plants minutely glandular; flowers 6-9 (10) mm long, sparsely pubescent; involucral tubes 4-6 (7) long; southern California from Riverside Co. south to central Baja California Norte.

33. C. fimbriata

DD. Involucral teeth unequal, the anterior one greatly elongated.

E. Anterior awn straight.

F. Outer tepals obovate, bilobed, the inner tepals erose; flowers $3.5-4 \mathrm{~mm}$ long; stamens 9; Monterey and San Luis Obispo cos.

17. C. rectispina

FF. Outer tepals linear-oblong, cuspidate or with three teeth, the inner entire; flowers 2-3 mm long; stamens 3; Coast Ranges from Contra Costa Co. south to Santa Barbara Co. east across Kern Co. to Tulare Co. in the Sierra Nevada. .... 19. C. uniaristata

EE. Anterior awns uncinate; outer tepals rounded, entire to emarginate or slightly bilobed, the inner entire to erose; flowers 2.5-3 mm long; stamens 3; Coast Ranges and Sierra Nevada from Mendocino and Lake cos. south to Santa Barbara Co. east to Tulare Co.

18. C. clevelandii

CC. Teeth of the involucre with a scarious or membranaceous margin.

D. Involucral teeth margins membranaceous and continuous across the sinuses or broad and extending up along the tooth to the awn.

E. Tepals entire.

F. Involucres tomentose to floccose or glabrate, 3-4 mm long; flowers densely pubescent, (1.5) 2.5-3 mm long; cauline leaves numerous, not in a whorl; Jackson Co. Oregon, south to Tulare, Kern, Ventura and Santa Barbara cos., California.

2. C. membranacea

FF. Involucres sparsely pubescent and hispid, 3-5 mm long; flowers sparsely pubescent, 3.5-4 (4.5) mm long; bracts a whorl about midlength; San Lucia Mountains, Monterey and San Luis Obispo cos. eastward to San Benito Co.

4. C. douglasii

EE. Tepals obcordate to bilobed; involucres sparsely pubescent and hispid, 3-4 mm long; flowers sparsely pubescent, 4-4.5 (5) $\mathrm{mm}$ long; bracts a whorl about midlength; foothills around the Central Valley from Shasta Co. south to Stanislaus and Tulare cos.

3. C. stellulata

DD. Involucral teeth margins scarious and parted or divided at the sinuses, sometimes with a distinct margin between the erect teeth.

E. Involucral teeth uncinate.

F. Tepals entire; flowers bicolored, the tubes yellow, the lobes white, glabrous, $2.5-3$ mm long; stamens 3-9; Santa Cruz and Monterey cos. south to Santa Barbara Co.

5. C. diffusa

FF. Tepals bilobed, erose or cuspidate; flowers not distinctly bicolored.

G. Plants prostrate or decumbent to ascending, less than $2.5 \mathrm{dm}$ high; involucres 1.5-2.5 (3) $\mathrm{mm}$ long.

H. Tepals erose.

I. Involucres distinctly margined, the margin white or pink to purple, the tube 2-2.5 (3) $\mathrm{mm}$ long; flowers 2-3.5 mm long; stamens 9; coastal beaches and inland mountains of Monterey and Santa Cruz cos.

6. C. pungens

II. Involucres thinly margined, the margin pinkish, the tube 1.5-2 (2.5) mm long; flowers 2-3 mm long; stamens 6-9; coastal mesas and foothills of San Luis Obispo and Santa Barbara cos. ............ 7. C. angustifolia

HH. Tepals cuspidate; involucres $1.5-3 \mathrm{~mm}$ long; flowers 2-3 mm long; San Francisco Peninsula.

8. C. cuspidata

GG. Plants erect, or if decumbent then involucres $3-4 \mathrm{~mm}$ long and bordered with a conspicuous margin.

H. Plants decumbent to erect, villous; involucres solitary, $2.5-4 \mathrm{~mm}$ long, thinly pubescent; flowers $2.5-4 \mathrm{~mm}$ long; bracts 2, opposite; coastal mesas and adjacent mountains in Alameda, San Mateo and Santa Cruz south to 
northern Monterey Co.

9. C. robusta

HH. Plants strictly erect, hirsute; involucres clustered, 3-4 mm long, hirsute; flowers 4-4.5 (5) $\mathrm{mm}$ long; bracts in a whorl about midlength; foothills and mountains surrounding the Central Valley of California.

3. C. stellulata

EE. Involucral teeth straight.

F. Flowers (3) $3.5-4.5 \mathrm{~mm}$ long, the tepals pubescent nearly throughout their entire length; involucral teeth tannish; plants spreading to decumbent or slightly ascending; Mendocino Co. 10. C. howellii

FF. Flowers (4) 5-6 mm long, the tepals pubescent only along the lower half; involucral teeth bright ivory or straw-colored; plants erect to spreading; Marin and Sonoma cos. 11. C. valida

BB. Involucral teeth 6 but with the small, alternating teeth obsolete and less than $1 \mathrm{~mm}$ long, these sometimes awnless.

C. Plants sparsely pubescent, not glandular or if so then the tepals white; tepals entire or if fimbriate then involucres campanulate; Baja California.

D. Flowers bicolored, only the tube yellow; tepals entire or fimbriate.

E. Tepals entire, thinly pubescent.

F. Flowers $4-5 \mathrm{~mm}$ long; filaments $2-2.5 \mathrm{~mm}$ long; achenes $2.5-3 \mathrm{~mm}$ long; mesas and hills east of the coast in the San Quintín area south to east of El Rosario.

28. C. turbinata

FF. Flowers (6) 7-9 mm long; filaments 4-6 mm long; achenes 3.5-4 mm long; Sierra San Borja.

29. C. mutabilis

EE. Tepals fimbriate or laciniate, glabrous.

F. Tepal lobes pink to rose, oblong, fimbriate; flowers $4.5-6 \mathrm{~mm}$ long; filaments $2-3 \mathrm{~mm}$ long; involucral tube 3-4 mm long; Cataviñá to south to Laguna Chapala.

30. C. rosulenta

FF. Tepal lobes white, broadly oblong to obovate, laciniate; flowers 4-6 (9) mm long; filaments 3-4 mm long, involucral tube 4-5 mm long, Laguna Chapala south to Desierto de Vizcaíno.

31. C. pulchella

DD. Flowers yellow throughout, 4-6 mm long, glabrous; tepals entire; El Arco area. 32. C. flava

CC. Plants minutely glandular and thinly pubescent; tepals fimbriate or laciniate, rose to red at maturity, sparsely pubescent with scattered hairs; flowers 6-9 (10) $\mathrm{mm}$ long; southern California from Riverside Co. south to Santa Cecilia, Baja California Norte.

33. C. fimbriata

AA. Involucres 3-5-toothed or 3-5-ribbed.

B. Involucral teeth (4) 5 .

C. Awns straight; flowers glabrous, $2.5-3.5 \mathrm{~mm}$ long, stamens basal; deserts of southern California in Inyo, Kern, northern Los Angeles and northwestern San Bernardino cos. ................. 1. C. spinosa

CC. Awns uncinate; flowers pubescent; stamens faucially attached on the floral tube.

D. Involucres campanulate, the tube $1.5-2.5 \mathrm{~mm}$ long, the teeth not leaflike; flowers white to rose, densely pubescent, 1.5-1.8 (2) mm long, mountains and coastal mesas of California and extreme northern Baja California. 34. C. polygonoides

DD. Involucres cylindric, the tube $3-4.5 \mathrm{~mm}$ long, the anterior tooth leaflike; flowers yellow, thinly pubescent, 1.5-2.5 mm long, widespread on the deserts and desert margins in Oregon and California eastward across Nevada to Utah and Arizona. 37. C. watsonii

BB. Involucral teeth 3 ; stamens faucially attached on the floral tube.

C. Involucres urceolate to campanulate; flowers densely pubescent; stamens 9.

D. Plants erect; involucres urceolate with the longer awns straight on a tooth $5-10 \mathrm{~mm}$ long; achene globose; widespread in deserts of eastern California, Nevada, Utah and Arizona south to northwestern México. 35. C. rigida

DD. Plants prostrate; involucres campanulate with the longer awns uncinate on a tooth $1.8-2 \mathrm{~mm}$ long; achenes narrow; endemic to San Diego Co., California. 36. C. orcuttiana

CC. Involucres cylindric.

D. Involucral tube well defined and markedly transversly corrugate; flowers thinly pubescent; stamens 6; deserts of southeastern California and southern Nevada to central Arizona and northwestern México.

38. C. comugata

DD. Involucral tube smooth; flowers glabrous; stamens 9; deserts of Baja California, México. 


\section{Key to the Subgenera}

A. Plants perennial; restricted to South America.

I. Chorizanthe (p. 108)

AA. Plants annual; mainly of North America.

B. Achenes globose, the embryo curved; stamens basally attached; plants of California and Oregon.

C. Involucres 5-lobed, unequally awned.

II. Quintaria (p. 108)

CC. Involucres 6-lobed, equally awned.

III. Eriogonella (p. 110)

BB. Achenes slender and the embryo straight or if achenes globose and the embryo curved then the stamens faucially attached on the corolla tube; plants of North and South America. ...... IV. Amphietes (p. 113)

Our division of Chorizanthe into a series of subgenera and sections follows the practice established in Eriogonum (Reveal 1968). As with that genus, the problem of rank, validity and competing previously published names is a problem. To a substantial degree Goodman (1934) resolved the circumscription of these taxa, but given the nature of the rules of nomenclature (and the changes therein), some of his names could prove to be technically incorrect unless all of the names were carefully typified. This we have attempted to do following provisions in the current International Code of Botanical Nomenclature (Greuter 1988).

The Gray Card Index incorrectly attributed the sectional names validly published by Torrey and Gray (1870), and maintained by Watson (1877), to the younger Hooker (1880). The Index credited Dammer (1892) with elevating Torrey and Gray's sect. Euchorizanthe to the subgenus rank, but in fact Dammer proposed the name himself without reference to the 1870 publication. Dammer did use Euchorizanthe, sensu Torrey and Gray, at the subsectional rank, incorrectly attributing the name at that rank directly to them.

The probable reason for the assignment of Torrey and Gray's (1870) sectional names to Hooker (1880) was the failure of Torrey and Gray to distinctly state a definite rank for their infrageneric names. Brizicky (1969) discussed the problem of rank in Torrey and Gray's $A$ flora of North America concluding that use of $\S$ in the first volume denoted the rank of subgenus, but in the second volume there was no direct statement and he concluded that their use of $\S$ was at the sectional rank.

When Torrey and Gray (1870) proposed to divide Chorizanthe into infrageneric groups they used the $\S$ followed by a name and a description. In their discussion of the genus they did not specificially state the rank they wished the $\S$ to represent. However, in Eriogonum they assigned all of Bentham's (1856) sections to the same rank they were using. Of the fourteen sections recognized in their 1870 paper on Eriogonum, nine had been proposed by Bentham, and given the consistency whereby the Bentham names were applied, one can only conclude that Gray (the actual author of the paper) was concurring with Benth's use of the sectional rank. Of greater significance, however, is a remark in the discussion of Censtrostegia where there is a direct reference to "sect. Mucroneae." From this remark we conclude that the rank intended by the $\S$ unquestionably was that of section.

Watson (1877), in his review of Eriogonum and Chorizanthe, stated that he was dividing Eriogonum "into three principal sections." He did not assign a rank to his superspecific taxa within Chorizanthe directly, but based on his statement under Eriogonum, we conclude Watson also intended to use the sectional rank. Parry (1884) was exact in his use of rank, stating specifically that his use of $\S$ was to denote the sectional rank. Like Hooker (1880), Parry credited Torrey and Gray (1870) as the original authors of the sections Acanthogonum, Mucronea and Euchorizanthe.

In this treatment we follow the opinion stated by previous authors and concur that Torrey and Gray (1870) subdivided Chorizanthe into sections. But, we must depart from Goodman (1934) with regards to the two sections credited by him to Bentham $(1836,1856)$. 
When Bentham (1836) discussed the tribe Eriogoneae initially, he specifically proposed a series of sections for the genus Eriogonum, providing not only a clear reference to the rank, but a description of each section as well. In Chorizanthe, however, he departed from this format.

In his key to the genera and sections in Eriogoneae, Bentham (1836) keyed out the three genera (Eriogonum, Chorizanthe and Mucronea) and within the first two, noted the sections. Under Eriogonum, he gave the lead (in Latin), then the $\S$ sign and a number, and finally the sectional name with the representative species listed in parenthesis. An example:

Folia ramorum floralium stipulata: § 1. Stipulata (E. angulosum).

Under Chorizanthe the same format was used except there was no descriptive phrase preceeding the §; he gave only the name and a list of species. However, between the name and the species list there was inserted a geographic note indicating where each section was found. An abbreviated example of the two sections follows:

$\S 1$. SUFFrUticosÆ (Chilenses): (C. virgata, peduncularis...).

§ 2. HERBACEÆ (Californicae): C. staticoides...).

In the subsequent treatment of Eriogonum, Bentham (1836) provided an actual description for each section. Thus, his first section appeared as follows:

\section{$\S 1$. STIPULATA. Folia caulina nuda, ramorum floralium stipulata.}

In Chorizanthe this is not done. The two sectional names were cited thusly:

\section{$\S 1$. Suffrutices (Chilenses).}

§ 2. Herbacea (Californicæ).

Ignoring the problem of Bentham changing names from "Suffruticosae" to "Suffrutices" for the South American perennials, we cannot conclude that the geographic phrases were intended by him to be descriptive. Thus, both of the Bentham sectional names in Chorizanthe must be considered nom. nud., and were not validly published until done so as sect. Suffrutices and sect. Herbaceae by Goodman (1934) nearly a century later.

When Parry revised Chorizanthe in 1884, he divided the genus into two groups: "Group A. Campylosperma" and "Group B. Orthosperma." He assigned various sections to these groups, provided a description of each but did not designate a type for either. When Dammer (1892) reviewed Chorizanthe in Die natürlichen Pflanzenfamilien he assigned the rank of section to Parry's two groups thereby making an effective transfer. Because the Code (Greuter 1988) allows for supplementary ranks to be intercalated or added (Art. 4.2), Parry's rank "Group" can be used and the names are validly published. The Gray Card Index incorrectly cited the authorship of both sections as "Parry ex Dammer" rather than "(Parry) Dammer."

Dammer (1892) also used the rank of subsection, denoting it with the symbol § used previously by most authors to indicate a section. In the discussion of Chorizanthe the rank is not defined, but in Polygonum, Dammer specifically assigns such names to the subsectional rank. Even though Dammer cited Parry and Torrey and Gray as the authors of the three subsectional names he listed in Chorizanthe, each must be regarded as a transfer and considered to be a new combination. 
The names Euchorizanthe and Chorizanthopsis used by Dammer (1892) at the subgeneric rank were not valid under previous editions of the Code (Art. 21.3; e.g., Stafleu 1978), but starting with the 1983 Sydney Code (Voss 1983), the provision relating to names ending with -oides and -opsis was deleted making such names as Chorizanthopsis legitimate. Since Dammer's subgenus is typified by the lectotype of the genus, Chorizanthe virgata, the name is still synonymous with the subg. Chorizanthe and cannot be used.

So that we might conserve the names established by Goodman (1934) for infrageneric taxa, we are lectotypifying each name so as to relegate the several possibly competing names to synonymy. Our actions will be noted below as appropriate.

I. Chorizanthe Benth. ex R. Br. subg. Chorizanthe. Chorizanthe sect. Euchorizanthe Torr. \& A. Gray, Proc. Amer. Acad. Arts 8: 192. 1870.-Chorizanthe subsect. Euchorizanthe (Torr. \& A. Gray) Dammer, Nat. Pflanzenfam. 3(1a): 11. 1892, but excluding the lectotype.-LECTOTYPE: Chorizanthe virgata Benth., selected by Goodman, Ann. Missouri Bot. Gard. 21: 19. 1934.

Chorizanthe Benth. ex R. Br. subg. Chorizanthopsis Dammer, Nat. Pflanzenfam. 3(1a): 12. 1892.- LECTOTYPE: Chorizanthe virgata Benth., selected here.

Chorizanthe Benth. ex R. Br. sect. Suffrutices Benth. ex Goodman, Ann. Missouri Bot. Gard. 21: 22. 1934.-LECTOTYPE: Chorizanthe virgata Benth., selected here.

Plants erect to spreading, thinly to densely pubescent herbaceous to suffrutescent perennials; leaves linear to spatulate; flowering stems slender to stout, not disarticulating at each node; bracts two, usually acicular, awn-tipped; involucres cylindric, 6-lobed, the lobes shallow and fused nearly throughout their entire length, recurved, mostly equally awned, the awns uncinate; flowers white to rose, pubescent; stamens 9, often faucially attached to the floral tube; achenes brown, narrow, the embryo straight.

A taxon of approximately ten species in the arid regions of northern and central Chile from the Atacama Desert south to the Santiago region, from sea level to $8000 \mathrm{ft}$ elev, flowering from Oct-Feb.

The South American perennials, critical to a full understanding of the genus Chorizanthe and fundamental to the evolutionary history of the subf. Eriogonoideae, have not been studied since Bentham reviewed them in 1856. Attempts to obtain support to conduct field work in Chile proved fruitless, and while the majority of the critical types were examined, without some understanding of the range of populational variation in the taxon and cytological studies, it is impossible to complete a revision of the genus. Accordingly, only the annual species are treated here.

II. Chorizanthe R. Br. ex Benth. subg. Quintaria Rev. \& Hardham, subg. nov.-TyPE: Chorizanthe spinosa $\mathrm{S}$. Wats.

A subgeneribus propris a involucris pentameris et embryoibus curvatis.

Plants prostrate to spreading, thinly pubescent annual herbs; leaves oblong; flowering stems slender, not disarticulating at each node; bracts 3, foliaceous, awn-tipped; involucres urceolate, mostly 5-lobed, the lobes shallow and fused more than three-quarters of their length, erect, unequally awned with one prominent and the other four shorter; flowers white, sometimes with a yellowish tube, glabrous; stamens 9, attached at the base of the tepals; achenes black, globose, the embryo curved. 
A monospecific taxon of the western Mojave Desert in southern California, from $2100-4000 \mathrm{ft}$ elev; flowering Apr-Jul.

The subg. Quintaria (from the Greek quintarius, consisting of five, alluding to the five-lobed involucres) is placed in a basal position among the annual elements of the genus, retaining such primitive features as three foliaceous bracts, five-lobed involucres, curved embryos and glabrous flowers. The awns are more characteristic of those typical of Chorizanthe than of Oxytheca or even Aristocapsa. The urceolate involucre is typical of Chorizanthe, but its broader aspect is reminiscent of that found in Eriogonum. Foliaceous bracts occur elsewhere in Chorizanthe, but rarely are they as large or as persistent as in this subgenus. The aneuploid chromosome number of $n=22$ reinforces our general belief that this subgenus is an isolated off-shoot, a taxon that retained a series of primitive features but resulted in an evolutionary deadend.

1. Chorizanthe spinosa S. Wats., Fl. Calif. 2: 481. 1880. Eriogonella spinosa (S. Wats.) Goodman, Ann. Missouri Bot. Gard. 21: 91. 1934-TYPE: "Near San Bernardino," actually from the Mojave Desert and perhaps from near Mojave, Kern Co., California, Jul 1879, Lemmon s.n. (holotype: GH!; isotype: ISC!).

Spreading to prostrate, thinly pubescent annual herbs $0.3-0.8$ (1) $\mathrm{dm}$ high and $0.5-8 \mathrm{dm}$ across; leaves basal, oblong, the blades (0.3) 0.5-1.5 (2) cm long, (3) 5-10 (12) mm wide, thinly pubescent on the upper surface, more densely so to tomentose below, obtuse to rounded apically, rather abruptly tapering to a pubescent petiole $0.5-2 \mathrm{~cm}$ long; inflorescences cymose, mostly flat-topped and open to densely dichotomously branched throughout, greenish to reddish; bracts 3, whorled, foliaceous, $0.5-1.5 \mathrm{~cm}$ long, linear-lanceolate to lanceolate, short petiolate, acerose, the awns straight, $1-3.5 \mathrm{~mm}$ long; involucres usually congested in small terminal clusters with 1-3 at the node of the dichotomies, the tube urceolate, weakly 3-angled but (4) 5-ribbed, 2-2.5 mm long, densely canescent, greenish, not corrugate, without a scarious margin, the teeth erect or nearly so and of two sizes, the longer anterior one prominent and thickened toward the base, 2-4 mm long, erect, with a straight awn 1-2.5 mm long, the remaining teeth smaller, $0.5-1 \mathrm{~mm}$ long, slightly divergent, with the straight awns $0.3-0.8 \mathrm{~mm}$ long; flowers exserted, cylindric, $2.5-3.5 \mathrm{~mm}$ long, white or the tube yellowish-white, glabrous, on pedicels $0.5-0.7 \mathrm{~mm}$ long, the tepals dimorphic, entire, the outer tepals spreading, broadly obovate and rounded apically, the inner tepals erect, narrowly oblanceolate and acute apically, about half the length of the outer ones, united half to two-thirds of their length; stamens 9, slightly exserted, the filaments $2.5-3 \mathrm{~mm}$ long, glabrous, the anthers $0.5-0.7 \mathrm{~mm}$ long, oblong, yellowish; achenes black, $2.5-3 \mathrm{~mm}$ long, glabrous, the globose base tapering abruptly to a 3-angled beak, the embryo curved; $n=(20) 22$ (23) (Hardham 1989).

Local and uncommon in sandy to gravelly places in the Mojave Desert of southern California from southeastern Kern and southern Inyo cos. south into adjacent northeastern Los Angeles and northwestern San Bernardino cos. to Antelope and Lucerne valleys, from $2100-4000 \mathrm{ft}$ elev; flowering from Apr-Jul.

Representative Specimens: UNITED STATES. CALIFORNIA: Inyo Co.: $12 \mathrm{mi} \mathrm{N}$ of Kramer, 27 May 1939, Jaeger s.n. (DS). Kern Co.: Red Rock Canyon, 1 May 1927, Abrams 11878 (DS, POM); Yucca, Jun 1884, K. Brandegee s.n. (F, MIN, UC); 0.5 mi SW of Haystack Butte, Edwards Air Force Base, 1 Jun 1978, Heckard 4843 (JEPS); Muroc Lake, 27 Apr 1929, Hoffmann s.n. (CAS, SBBG); Mojave, 1918, Morse s.n. (CAS, DS, NY, PH, RM, UC, US); 3 mi S of Muroc Lake, 7 May 1927, Peirson 7274 (CAS, RSA, UC); Red Rock Canyon near U.S. Highway 395, $20 \mathrm{mi}$ N of Mojave, 19 May 1943, C.N. Smith 794 (ARIZ, JEPS, OKL). Los Angeles Co.: E side of Muroc Dry Lake, 19 May 1930, Hoffmann s.n. (ARIZ, B, BM, DAO, DS, G, GH, MIN, MO, MONTU, NY, OSC, RM, RSA, SD, TEX, UC, US); Antelope Valley, along 60th Avenue, $0.2 \mathrm{mi} \mathrm{N}$ of J Street, 6 air mi W of Lancaster, 17 
May 1988, Reveal 6794 (BM, BRY, CAS, MARY, MO, NY, OSC, RSA, WIS). San Bernardino Co.: Kramer, 18 Jul 1912, K. Brandegee 217 (ARIZ, B, BM, BR, CAS, DS, E, F, G, GH, JEPS, K, LA, LE, MO, MPU, NY, ORE, POM, RM, UC, US, WIS, Z); Adelanto, 12 May 1927, M.E. Jones s.n. (CPI, POM); Rabbit Springs, May 1882, Parish \& Parish 825 (DS); along the road to Harper Dry Lake, $0.4 \mathrm{mi} \mathrm{N}$ of California Highway 58, $18 \mathrm{Mar} 1988$, Reveal \& Broome 6656 (CAS, MARY, MO, NY, RM, RSA, WIS); 3 mi S of Lockhart, 27 Apr 1966, Twisselmann 12048 (CAS, DAO, RSA, SBBG). A total of 66 collections are known to us.

The actual place where Lemmon gathered the type of Chorizanthe spinosa (from the Latin spinosus, thorny, alluding to the sharply awned bracts and involucres) is uncertain. The plant is not found near San Bernardino currently and it is unlikely that it ever was. We have seen a collection,(Lemmon 1473, UC!) where Lemmon wrote "discovered while the train was delayed by a hot axle near Mohave, S. Cal." This we take to mean the town of Mojave, Kern Co., California. The sheet was dated Jun 1878 . The holotype was supposedly collected in Jul 1879 , but perhaps this was when Lemmon sent it to Watson at Harvard Unviersity. On the holotype, Watson annotated the label to read "Mohave," but we suspect he meant the Mojave Desert rather than the townsite.

We do not accept Parry's (1884) contention that Chorizanthe spinosa should be associated with Centrostegia, a taxon he considered, like Watson (1877), to be a section of the genus Chorizanthe.

III. Chorizanthe R. Br. ex Benth. subg. Eriogonella (Goodman) Rev. \& Hardham, comb. et stat. nov. Eriogonella Goodman, Ann. Missouri Bot. Gard. 21: 90. 1934.-TYPE: Eriogonella membranacea (Benth.) Goodman.

Plants erect, densely pubescent annual herbs; leaves linear to narrowly oblanceolate; flowering stems simple, slender to stout, not disarticulating at each node; bracts usually 2 and opposite, foliaceous, awn-tipped; involucres urceolate, 6-lobed, the lobes shallow and fused throughout their length, spreading above with a broad, continuous membranaceous margin, the teeth all equally awned and uncinate; flowers white to rose, densely pubescent; stamens 9, attached at the base of the tepals; achenes brown, globose, the embryo curved.

A monospecific taxon of south-central Oregon and California in the coastal ranges and on the western foothills of the Sierra Nevada southward to the Transverse Ranges and Tehachapi Mountains of Ventura and Kern cos. from $150-4500(5100) \mathrm{ft}$ elev, flowering Apr-Jul.

Chorizanthe membranacea has long been considered an unusual element within the genus. Its strict, upright habit, the numerous basal and cauline leaves and the broad, continuous, membranaceous margins of the involucre all combine to emphasize the isolated nature of the taxon. Goodman (1934) concluded that the existence of the curved (as opposed to the straight) embryo of this species and $C$. spinosa was sufficient to warrant the establishment of a new genus, Eriogonella (from the genus Eriogonum and the Latin diminutive -ella meaning little). At first he placed both species in the same genus, but in later herbarium annotations, he was going to move $C$. spinosa into its own genus.

We concur with Goodman's later conclusion that Chorizanthe membranacea and C. spinosa are unrelated and believe that the two represent wholly independent lines that likely evolved from a primitive annual ancestral source. Given our working hypothesis that the separation of the annual and perennial members of Chorizanthe occurred during the early Tertiary (Reveal 1978; Shields \& Reveal 1988), we propose that there was considerable divergence resulting in diverse groups of annuals with many of those groups becoming extinct leaving isolated members to persist to the present day. Conversely as in Eriogonum subg. Oregonium, 
an annual taxon with a distribution similar to that of Chorizanthe subg. Amphietes in North America, several groups have undergone recent and rapid diversification. In ecological and morphological variation and geographic range these species of Chorizanthe parallel the successful species of Eriogonum belonging to the subg. Oregonium. In both subgenera of these genera, for example, morphological differentiation among the species is weak, but such differences are reinforced by aneuploidy and geographic isolation (especially that manifested by edaphic factors). We suspect these basically unrelated subgenera have a similar evolutionary history, but unlike the case in the whole of Eriogonum where there is today a wealth of subgenera, in Chorizanthe few have evolved.

As for the case of Eriogonella itself, we have been unable to justify its continued recognition at the genus level. From our analysis of characters, the distinctiveness of Chorizanthe spinosa and $C$. membranacea from the rest of the annual members of the genus is significant. However, that level is not as great as that between these species and others we are recognizing as distinct genera, namely Mucronea and those related to Centrostegia. The only genus that is not as distinct is Lastarriaea, a taxon derived directly from Chorizanthe subg. Amphietes rather than ancestral to it as is the case of the above genera. If Eriogonella is to be recognized, then a new genus must be established to accommodate Chorizanthe spinosa as well.

We do not accept Parry's (1884) notion that Chorizanthe membranacea should be associated with Centrostegia.

2. Chorizanthe membranacea Benth., Trans. Linn. Soc. London 17: 419. 1836. Eriogonella membranacea (Benth.) Goodman, Ann. Missouri Bot. Gard. 21: 91. 1934. - TYPE: Without location data, but probably from near Monterey, Monterey Co., California, "1833," Douglas s.n. (holotype: K!; isotypes: B, BM, BR, CGE, DAO, E, GH, K, LE, MO, OXF!).

Erect, wooly-floccose annual herbs 1-6 (10) dm high and 0.5-3 (5) dm across; leaves basal and alternate along the stems, linear to narrowly oblanceolate, the blades (1) $1.5-5 \mathrm{~cm}$ long, $1-3 \mathrm{~mm}$ wide, thinly to densely floccose on the upper surface, rather densely tomentose below, acute apically, gradually tapering to an indistinct pubescent petiole $0.1-0.5(0.8) \mathrm{cm}$ long; inflorescences strict and cymose, open, dichotomously branched throughout, white to greenish; bracts usually 2 and opposite, rarely in whorls of 3-5, similar to the leaves only more reduced, 3-30 $\mathrm{mm}$ long, short petiolate, acerose, the awns straight, $0.5-1 \mathrm{~mm}$ long; involucres usually congested in small terminal clusters with 1-3 at the node of the dichotomies, the tube urceolate and ventricose basally, 3-angled but 6-ribbed, 3-4 mm long, tomentose to floccose or glabrate with age, greenish to brownish, not corrugate, with a conspicuous, broad, white, membranaceous margin extending across the sinuses, the teeth spreading, all the same size, the uncinate awns $0.7-1.5 \mathrm{~mm}$ long; flowers 1 (2), slightly exserted, subcylindric, (1.5) 2.5-3 $\mathrm{mm}$ long, white to rose, densely pubescent without, on pedicels $0.8-1.8$ (2) $\mathrm{mm}$ long, the tepals slightly dimorphic, entire and rounded apically, the outer tepals obovate, the inner tepals spatulate, united about two-thirds of their length; stamens 9 , slightly exserted, the filaments $1.5-2.5 \mathrm{~mm}$ long, glabrous, the anthers $0.2-0.3 \mathrm{~mm}$ long, oval, pink to red; achenes brown, $2.5-3 \mathrm{~mm}$ long, glabrous, the globose base tapering abruptly to a 3-angled beak, the embryo curved; $n=19-20$ (21), 40-42 (Hardham 1989).

Widespread and mostly locally common mainly in sandy to gravelly or rocky places in the mountains and foothills of Jackson Co., Oregon, south in the Coast Ranges of California from Siskiyou, Trinity and Shasta cos. south to San Luis Obispo Co., and on the western foothills of the Sierra Nevada from Butte Co. south to Tulare Co., and on the Transverse Ranges of Santa Barbara and Ventura cos. to the Tehachapi Mountains of Kern Co., from 
$150-4500$ (5100) ft elev, flowering from Apr-Jul.

Representative Specimens: UNITED STATES. CALIFORnIA: Alameda Co.: Sunol Valley Regional Park, May 1974, Lagel s.n. (CAS). Amador Co.: Fisher's Cabin, 19 Apr 1894, Hansen 492 (E, G, L, NY, POM, US). Butte Co.: Berry Canyon, near Clear Creek, 6 May 1902, Heller \& Brown 5465 (BKL, DS, E, F, G, GH, L, LE, MO, NY, PH, POM, US). Calaveras Co.: Stanislaus River at the Copperopolis-Sonora Road, 22 May 1921, Tracy 5707 (UC, WTU). Colusa Co.: Bear Valley Road, $1.3 \mathrm{mi} \mathrm{N}$ of California Highway 16-20, 12 May 1963, Addicott 41 (ARIZ, DAO, MIN). Contra Costa Co.: W slope of Mt. Diablo, 15 May 1941, Rose 41230 (ILL, ND, RSA, SMU, TEX, UC, WS, WTU). El Dorado Co.: North Fork of Webber Creek, 3 mi E of Camino, 5 Jun 1943, Robbins 1654 (CAS, GH, SMU, UC, US, UTC); 9 mi E of Placerville on road to Pino Grande, 11 May 1946, Wiggins 11227 (CAS, DS, RM, WS, WTU). Fresno Co.: Warthan, 11 May 1893, Eastwood s.n. (F, G, MIN, UC). Kern Co.: Kern Canyon, 1 mi above its mouth, 26 Apr 1905, Heller 7777 (BKL, DS, E, F, G, GH. ISC, L, MO, NY, PH, UC, US); Aqueduct road, NE slope of a tributary of Pastoria Canyon, Tejon Ranch, Tehachapi Mountains, 24 Jun 1965, Twisselmann 11090 (B, CAS, COLO, DAO, RSA, SBBG, W). Lake Co.: about the Geysers and Pine Mountain, 1860-1867, Bolander 3959 (CAS, DS, GH, K, MO, UC, US, WS); along California Highway 175, $2.5 \mathrm{mi}$ SW of California Highway 29, 2 Jun 1988, Reveal 6976 (BM, BR, BRY, CAS, CLEM, G, K, KW, LE, MARY, MEXU, MO, NY, OKL, OSC, RM, RSA, SMU, US, UTC, VT, WIS, Z). Madera Co.: $7.6 \mathrm{mi}$ S of Coarsegold on California Highway 41, 7 May 1963, Raven 18339 (DAO, DS, RSA, US). Marin Co.: Rock Spring, Mt. Tamalpais, 16 Jun 1946, Rose 46157 (ARIZ, B, CAS, G, MARY, RSA, UC). Mariposa Co.: Clark's Ranch along a branch of the Merced River, 1865, Torrey 436 (GH, NY). Mendocino Co.: along the Russian River, 8 mi S of Hopland, 6 Jun 1938, Tracy 15849 (TEX, UC). Merced Co.: Piedra Azul Canyon, 0.7 mi SW of Piedra Azul Spring, 4 May 1940, Constance et al. 2590 (ARIZ, BKL, BRY, CAN, CAS, DS, F, GH, IDS, ILL, K, MICH, MO, ND, NO, NY, OKL, POM, RM, SBBG, UC, UCSB, US, UTC, WS, WTU). Monterey Co.: Nacimiento-Ferguson Road, 3 mi E of California Highway 1, 17 Jun 1978, Broome \& Cagle 2166 (BRY, CAS, MARY, OSC, RSA, UTC, WIS); Tassajara Hot Springs, Jun 1901, Elmer 3249 (DS, G, K, MIN, MO, US). Napa Co.: 5 mi S of Monticello on Steel Canyon Road, 30 Apr 1934, Ewan 8843 (LA, NO). Nevada Co.: Rock Creek, E of old McCourney Road Bridge, 14 mi E of Wheatland, 27 Apr 1965, True 1826 (CAS, RENO). Placer Co.: W side of Big Crater, 28 May 1978, Stebbins 7883 (CAS). Sacramento Co.: near Folsom, 21 May 1938, Copeland 1577 (ASU, DS, GH, SBBG, UC). San Benito Co.: Panoche Pass, 20 Apr 1938, Eastwood \& Howell 5221 (CAS, ISC, MICH, PENN, UC, WTU); The Pinnacles National Monument, 19 May 1937, Rose 37295 (ISC, OKL, RSA, UC, US, UTC, W, WTU); 2 mi W of Llanada on the Panoche Pass Road, 28 Apr 1940, Wiggins \& Ferris 9395 (BRY, CAN, DAO, DS, GH, IDS, LL, MICH, MONTU, NY, RM, RSA, TEX, UT, UTC, WS, WTU). San Luis Obispo Co.: along Salinas River, $10 \mathrm{mi}$ E of Santa Margarita along California Highway 178, 12 May 1938, Ferris \& Rossbach 9454 (DS, GH, ORE); 4.1 mi W of La Panza, 26 Apr 1934, Keck 2825 (DS, MICH, POM, UC). San Mateo Co.: Crystal Springs, 1867, Bolander s.n. (GH). Santa Barbara Co.: on Zaca Ridge Road NE of Zaca Peak and the head of Sulphur Springs Canyon, San Rafael Mountains, 3 May 1961, E.R. Blakley 4315 (CAS, JEPS, SBBG); Santa Barbara, May 1902, Elmer 3774 (DS, E, G, K, MIN, MO, NY, US, VT, Z). Santa Clara Co.: above Arnolds, near Madrone Springs, 29 May 1895 , Dudley 4050 (DS, GH, ISC, NY, RSA, UC, US); slopes beyond Hall's Valley, on the Mt. Hamilton Road, 30 May 1907, Heller 8597 (BKL, DS, E, F, G, GH, ISC, L, MIN, MO, NY, PH, US, WIS, WU); divide between San Antonio Valley and head of Arroyo Bayo, Mount Hamilton Range, 29 Apr 1934, Sharsmith 1010 (BRY, NY, OKL, RM, SMU, UC). Santa Cruz Co.: Deer Ridge Farm, summit of Santa Cruz Mountains, 8 Jul 1907, Pendleton 952 (POM, UC). Shasta Co.: Pitt River, 28 May 1913, L.E. Smith 300 (BM, CAS, GH, US). Siskiyou Co.: Klamath River between Dutch Creek and Deadman Gulch, Siskiyou Mountains, 9 Jun 1934, Wheeler 2665 (CAS, GH, MARY, POM, WTU). Solano Co.: Gates Canyon, near Vacaville, 27 Apr 1902, Heller \& Brown 5385 (BKL, DS, E, F, GH, L, LE, MO, NY, PH, US); Vaca Mountains, 1 Jun 1891, Jepson s.n. (ARIZ, DS, JEPS, MIN, MSC, UC). Sonoma Co.: Pepperwood Ranch, 11 Jul 1981, DeNevers \& Harding 1759 (CAS). Stanislaus Co.: La Puerta Creek, May 1903, Elmer 4360 (ARIZ, BKL, CAS, COLO, DS, E, G, MICH, MIN, MO, NY, ORE, POM, SMU, UC, US, WIS, Z). Sutter Co.: S side of the South Butte, Sutter Buttes, W of Marysville, 21 May 1984, Ahart 4629 (MO, RSA); Lassen's Farm [actually mouth of Bear River at the Feather River], 25 Mar 1846, Fremont 445 (GH, K, NY). Tehama Co.: logging road W of Paskenta near the 5 mi post, 30 May 1953, M.O. Baker 12715 (RSA). Trinity Co.: along the trail to Red Mountain, 27 May 1978, T. Nelson 4048 (BRY, HSC, MARY, RSA); Big Bar, 31 May 1926, Tracy 7526 (CAS, DAO, DS, POM, UC, UTC, Z). Tulare Co.: Middle Tule River, Apr-Sep 1897, Purpus 5654 (E, GH, K, MO, US); $2.8 \mathrm{mi}$ WNW of Milo on road to Yokohl Valley, 8 Jun 1967. Thorne \& Everett 37035 (CAS, GH, RSA, UT, Z); 11.5 mi E of Centerville on grade to Squaw Valley, 16 May 1933, Wolf 4759 (RM, RSA, SD, TEX, UT, WTU). Tuolumne Co.: E of Twain Harte Post Office, 13 Jun 1944, Alexander \& Kellogg 3696 (BRY, GH, MO, NY, OKL, RM, UC, US, UTC); 1 mi SW of Jacksonville, 2 May 1960, Rose 60012 (B, BRY, CAS, COLO, E, ENCB, MICH, MIN, OBI, RM, RSA, SMU, TEX, wS); Coulterville-Big Oak Flat Road along Moccasin Creek, $3.4 \mathrm{mi}$ S of Moccasin Power House, 22 May 1933, Wolf 4871 (COLO, RSA, SD, UC, WTU). Unknown 
Co.: without location data, 1883, Parry 263 (F, G, ISC, LE, MIN, NEB, NY, ORE, POM, UC, US, VT). Ventura Co.: meadow between California Preparatory School and Ojai, 24 Jun 1952, Pollard s.n. (CAS, SBBG). Yolo Co.: 2 mi E of Recreation Beach along California Highway 128, 27 Apr 1963, Maze 21 (ARIZ, DAO, DAV, MIN, OSC, RSA, UTC, WTU). ORegon. Jackson Co.: Stein's Butte, $2 \mathrm{mi} \mathrm{N}$ of the California State line, 27 Jun 1931, M.E. Peck $16427 a$ (CAS, NY, WILLU). A total of 454 collections are known to us.

Chorizanthe membranacea (from the Latin membranaceus, of skin or parchment, alluding to the membranaceous margin of the involucre) is morphologically uniform throughout its range and even ecologically the species is not found in a particularly wide array of habitats. The plant is found mainly on gravelly banks or outcrops in oak dominated grasslands where it occurs in local populations along the foothills of the Central Valley. At slightly higher elevations on the Coast Ranges and in the Sierra Nevada the species is found in mixed pine-oak woodlands; here the plants tend to be in more widely scattered populations. Some populations may be found on serpentine outcrops in the southern Coast Ranges.

Hardham found that an occasional flower of Chorizanthe membranacea would have as many as twelve anthers, and sometimes two flowers in a single involucre.

IV. Chorizanthe R. Br. ex Benth. subg. Amphietes Rev. \& Hardham, subg. nov.-TYPE: Chorizanthe douglasii Benth.

A subg. Chorizanthe plantis annuis et embryoibus pro parte maxima strictis differt.

Plants prostrate to spreading or erect, mostly thinly pubescent annual herbs; leaves linear to lanceolate or obovate; flowering stems slender to stout, sometimes disarticulating at each node; bracts mostly 2, opposite, scalelike or if foliaceous then similar to the basal leaves only reduced, occasionally deciduous in early anthesis, with or without awns; involucres cylindrical to narrowly turbinate or campanulate, occasionally ventricose basally, 3-, 5- or 6-lobed, the lobes typically shallow and fused at least half of their length, spreading and with or without a membranaceous or scarious margin, the teeth typically awned with the alternating awns of different lengths and the anterior one longer than the rest; flowers white to rose or yellow, mostly thinly pubescent without along the midrib; stamens 3-9, attached at the base of the tepals or faucially on the tepals, occasionally the filaments united into a short tube; achenes brown, the slender to globose base tapering to a slightly or distinctly 3-angled beak, the embryo straight or rarely curved.

A taxon of 39 species one of which occurs from extreme southern Perú south to central Chile in South America, with the majority of the rest restricted to California with some few widely distributed in western North America from Washington and Idaho south to northwestern Mexixco, from -230 below sea level to 10,000 ft elev; flowering throughout the year.

\section{Key to the Sections}

A. Stems not disarticulating at the nodes.

B. Involucral tubes 6-toothed and 6-ribbed.

IVA. Herbaceae (p. 115)

BB. Involucral tubes not both 6-toothed and 6-ribbed.

IVB. Acanthogonum (p. 175)

AA. Stems disarticulating at the nodes.

B. Involucral tubes 6-ribbed; stamens 3.

IVC. Fragile (p. 188)

BB. Involucral tubes 3-ribbed; stamens 9. IVD. Clastoscapa (p. 194)

As here defined, the subg. Amphietes (from the Greek amphietes, yearly, alluding to the annual versus perennial habit of the taxon) consists of those annual species of Chorizanthe that have a slender achene due to a straight embryo, or if the achene is globose due to a 
curved embryo then the stamens are faucially inserted near or at the top of the floral tube rather than basally as in subg. Quintaria and subg. Eriogonella. Faucially inserted stamens are found in some (all?) of the perennial species (subg. Chorizanthe) and in the sect. Acanthogonum of the subg. Amphietes. So far as currently known, none of the perennials has a curved embryo (Bentham 1856) so we are uncertain if there is a relationship between a curved embryo and staminal insertion, but at the moment we think not. Accordingly, we continue to maintain the sect. Acanthogonum within Amphietes rather than elevate the section to the subgeneric rank.

The members of the subg. Amphietes are widely distributed in western North America, but that expansive distribution is due to just two species, $C$. brevicomu, which ranges from southern Idaho and adjacent southeastern Oregon southward to northwestern México, and C. watsonii which occurs from southeastern Washington and western Idaho southward into southern Utah and California. With the exception of $C$. corrugata and $C$. rigida which range from California across Nevada into Utah and Arizona, the remainder of species assigned to the subg. Amphietes are restricted to California and Baja California. Of that number, 23 are endemic to California, seven are endemic to Baja California, and four occur in both areas.

The only South American representative is Chorizanthe commissuralis. It occurs in the arid deserts of extreme southern Perú and northern Chile and belongs to the same section (Fragile) as C. brevicomu, the most widely distributed species of the genus in North America. It appears that $C$. commissuralis is a Pleistocene arrival from North America and one of the members of a large suite of recent introductions (Raven 1963; Reveal 1978).

Four sections are recognized in the subg. Amphietes. The largest is the sect. Herbaceae with 31 species divided among eight subsections. With few exceptions, the species are found along the Pacific Coast or in the adjacent mountains. The sect. Acanthogonum is divided into five monospecific subsections. Its five species are widely distributed in western North America in arid habitats. The sect. Fragile consists of the two most widely distributed species, $C$. brevicomu and $C$. commissuralis. Like the final section, Clastoscapa, and its only species, $C$. interposita of Baja California Norte, the species of sect. Fragile have disarticulating stems. This factor has certainly aided in the dispersal of these species.

The subg. Amphietes evolved from an ancestral perennial taxon. The question whether or not that group was a diploid or a tetraploid cannot be answered until the extant South American perennials can be studied. Likewise, it is difficult to determine if the immediate ancestor of the subg. Amphietes was annual or perennial. If it was a perennial, then the taxon would most certainly have been a short-lived herbaceous perennial. Interestingly, our analysis of characters tends to place the coastal Chorizanthe pungens complex in the basal position among the present-day species even though the habit of the C. palmeri complex appears more reminiscent of a perennial condition. This would tend to support the idea that the immediate ancestor of the subg. Amphietes would have been an annual.

The subsequent evolution of the subgenus was clearly one that involved fundamental modification of the involucre. The less advanced members have a narrowly cylindrical tube with short teeth (sect. Herbaceae subsects. Legnota, Pungentes, Petasata, Uniaristatae, Parryanae, Staticoideae, Procumbentes). The more advanced members (sect. Acanthogonum) have a broad tube with thickened, long teeth. The number of teeth decrease from six to three in this transistion. The intermediate condition is seen in the more advanced subsections of sect. Herbaceae (Flavae) where the tube is long and narrow but the teeth are thickened and broad as in the sect. Acanthogonum. 
Although the sects. Fragile and Clastoscapa are placed side-by-side in our linear sequence, the two are not all that closely related. The sect. Fragile appears to be most closely associated with the subsect. Uniaristatae whereas the sect. Clastoscapa falls nearest the subsect. Flavae. However, in both instances, Fragile and Clastoscapa are well removed from these respective subsections.

IVA. Chorizanthe R. Br. ex Benth. sect. Herbaceae Benth. ex Goodman, Ann. Missouri Bot. Gard. 21: 35. 1934.-LECTOTYPE: Chorizanthe douglasii Benth., selected here.

Chorizanthe R. Br. ex Benth. subg. Euchorizanthe Dammer, Nat. Pflanzenfam. 3(1a): 11. 1892. - LECTOTYPE: Chorizanthe douglasii Benth., selected here.

Chorizanthe R. Br. sect. Anisogonum Roberty \& Vautier, Boissiera 10: 85. 1964.-TYPE: Chorizanthe procumbens Nutt.

Chorizanthe R. Br. sect. Eriogonellopsis Roberty \& Vautier, Boissiera 10: 85. 1964.-TYPE: Chorizanthe pungens Benth.

Plants prostrate to spreading or \pm erect; leaves lanceolate to ovate; flowering stems slender to stout, not disarticulating at each node; bracts awned; involucres cylindrical to campanulate, occasionally ventricose basally, 3-angled and 6-ribbed, with or without a membranaceous or scarious margin, the teeth typically awned with alternating awns of different lengths and the anterior one longer than the rest; flowers white to rose or yellow, the tepals thinly pubescent; stamens 3-9, attached at the base of the tepals.

A highly variable section of 31 species arranged in eight subsections of California and Baja California mainly on the coast and in the Coast, Transverse and Peninsular ranges and the Sierra Nevada southward to the Desierto el Vizcaino of northern Baja California Sur, from near sea level to $6650 \mathrm{ft}$ elev; flowering Jan-Jul.

\section{Key to the Subsections}

A. Involucral margins continuously membranaceous across the sinuses. IVA(1). Legnota (p. 116)

AA. Involucral margins not continuously membranaceous across the sinuses (see also $C$. stellulata).

B. Outer tepals entire or variously lobed but not fimbriate, or if so then involucres not narrowly cylindrical and plants of Baja California.

C. Inner and outer tepals of essentially equal length and plants of Santa Barbara Co. northward; filaments free; involucres 6-toothed with the alternating 3 shorter, the anterior one slightly long awned, with or without a distinct margin between the teeth; stamens variable 3-9; plants decumbent to erect with spreading pubescence; mainly on or near the coast. IVA(2). Pungentes (p. 120)

CC. Inner and outer tepals of unequal lengths or if so then plants of extreme southeastern Ventura Co. southward; involucres without a distinct margin; stamens 6 or 9; plants mostly erect or spreading with appressed pubescence; mainly in the mountains away from the coast.

D. Involucral teeth with the anterior one distinctly longer awned than the others, this one typically not uncinate, occasionally all the teeth straight, or if the teeth all uncinate then the plants grayish, strigose and the plants of Ventura $\mathrm{Co}$. south; tepals not entire.

E. Involucres with the anterior tooth long and straight or slightly curved and the remaining ones much shorter and uncinate (the elongated anterior tooth uncinate in C. clevelandii); flowers white, red or purple, sometimes with a yellow tube, the tepals with at least one of the whorls of tepals erose, emarginate, lobed, cuspidate or fimbriate; northern and central California.

F. Stamens 9; outer tepals obovate to bilobed or rarely erose, the inner tepals fimbriate, shallowly bilobed or rarely erose; Monterey and Fresno cos. south to northern Santa Barbara Co.

IVA(3). Petasata (p. 134)

FF. Stamens 3; tepals all erose; Coast Ranges from Mendocino and Lake cos. south to Ventura Co., and in the southern Sierra Nevada from Tulare and Kern cos. IVA(4). Uniaristatae (p. 144) 
EE. Involucral teeth all straight or all uncinate and the plants grayish pubescent, the longer three alternating with the shorter ones; flowers greenish-white to white or rose, the tepals all erose; southern California from Los Angeles and San Bernardino cos. south to Orange and western Riverside cos., California, and north-central Baja California Norte.

IVA(5). Paryanae (p. 147)

DD. Involucral teeth all of the same length or with three longer ones alternating with the three shorter teeth; awns uncinate; tepals entire.

E. Flowers yellow to pale yellow or rarely white; filaments united into a pilose-cilate tube; plants yellowish-green; southeastern Ventura Co. east to western San Bernardino Co. south through San Diego Co. into Baja California Norte as far south as the San Quintín area. IVA(6). Procumbentes (p. 150)

EE. Flowers white to rose or red; filaments free; plants reddish or greenish; central and southern Coast Ranges and off-shore islands from Monterey Co. south to San Diego Co., and in the southern Sierra Nevada from Madera Co. south through the Transverse Ranges and mountains of southern California to extreme north-central Baja California Norte.

IVA(7). Staticoideae (p. 154)

BB. Outer tepals fimbriate to laciniate, or if entire then the involucres turbinate with a long, narrow tube and broad, thickened, pronounced teeth bearing long awns alternating with highly reduced short awned or awnless teeth; southern California south to northern Baja California Sur, México.

IVA(8). Flavae (p. 166)

The sect. Herbaceae (from the Latin herbaceus, of herbs, contrasting the herbaceous versus perennial nature of the two sections recognized by the author) is defined here much as Goodman (1934) did previously. It encompasses the bulk of annual Chorizanthe species in North America and is essentially restricted to those members of the genus that occur in California and Baja California. Although Bentham (1836) included C. membranacea within the section, Goodman excluded it as Eriogonella, and while we retain the species in Chorizanthe, we place it in its own subgenus. Accordingly we propose $C$. douglasii as the lectotype for Bentham's sect. Herbaceae.

Like Goodman before us, we continue to divide the sect. Herbaceae into a series of subsections. We have divided the section into somewhat finer units than Goodman, and rearranged their linear order slightly, but our treatments are not fundamentally different in this respect. Some species have been reassigned to different subsections, however, the most notable being the transfer of Chorizanthe fimbriata from the subsect. Staticoideae to the subsect. Flavae, and the removal of $C$. douglasii and $C$. stellulata from the Pungentes to a new subsection, Legnota.

IVA(1). Chorizanthe Benth. ex R. Br. subsect. Legnota Rev. \& Hardham, subsect. nov.TYPE: Chorizanthe douglasii Benth.

A subsect. Pungentes involucris conspicue marginatis differt.

Plants spreading to weakly erect; leaves basal, narrowly lanceolate to oblanceolate; bracts foliaceous, often in a whorl about midlength along the stem; involucres cylindrical, hispid especially along the ridges, with a conspicuous membranaceous margin either extending across the sinuses or up the tooth to the awn, the teeth all of the same size and short awned; flowers well exserted from the involucre, white to rose, slightly pubescent without, the tepals slightly irregular to bilobed or denticulate apically, both whorls of essentially the same length or the inner one slightly shorter; stamens 9 , attached at the base of the tepals.

A bispecific taxon of the foothills and mountains of California bordering the Central Valley, from 100-5000 $\mathrm{ft}$ elev, flowering Apr-Jul. 


\section{Key to the Species}

A. Involucral margins white, the tube $3-4 \mathrm{~mm}$ long; flowers $4-4.5 \mathrm{~mm}$ long, the tepals obcordate to bilobed apically; leaves hirsute on both surfaces, 0.8-2 (2.2) $\mathrm{mm}$ wide; filaments 4-5 mm long; widespread in the foothills and mountains bordering the Central Valley of California from Shasta Co. south to Stanislaus Co. along the west side, and south to Tulare Co. along the east side.

3. C. stellulata

AA. Involucral margins purple, the tube $3-5 \mathrm{~mm}$ long; flowers $3.5-4(4.5) \mathrm{mm}$ long, the tepals bilobed or denticulate apically; leaves villous on both surfaces, 1-4 (10) $\mathrm{mm}$ wide; filaments 3-4 mm long; Santa Lucia Mountains of Monterey and San Luis Obispo cos. eastward to the valley foothills in San Benito Co. .... 4. C. douglasii

The subsect. Legnota (from the Greek legnotos, with a colored border, alluding to the conspicuous white or purplish margins of the involucre) is defined to include those species of the genus with broad, distinct membranaceous involucral margins and a whorl of foliaceous bracts about midlength along the stem. This latter feature appears to be similar to the situation found in Eriogonum subg. Oligogonum Nutt., and specifically in such species as $E$. heracleoides Nutt. where the whorl of bracts appears to represent a stem terminated by the bracts atop of which is a reduced inflorescence. The inflorescence in this instance consists of a series of branches, each node of which is subtended by bracts, along with a series of bracteated involucres. This is the case in $C$. douglasii and $C$. stellulata, and as we shall see below, in some members of the subsect. Petasata.

When one compares the inflorescences of the species in subsect. Legnota with the highly branched inflorescences of subg. Chorizanthe (i.e., Chorizanthe paniculata Benth.), one can see that the situation in subsect. Legnota is probably due to a reduction of the kind typical in the perennials, but unlike that found in either of the other subgenera considered to this point, subg. Quintaria and subg. Eriogonella. If our working hypothesis is correct that Quintaria and Eriogonella arose from a curved embryo ancestral group while the subg. Amphietes is an annual derivative from the perennial subg. Chorizanthe, then it follows that these two species which in our analysis of characters fall out first within the subgenus, must be the basal unit within the subgenus in part because of their inflorescence type.

3. Chorizanthe stellulata Benth. in A. DC., Prodr. 14: 26. 1856.-TYPE: Valley of the Sacramento, California, 1847, Hartweg 1937 (holotype: K!; isotypes: BM, CGE, F, GH, $\mathrm{K}, \mathrm{LE}, \mathrm{OXF}$ !).

Erect, hirsute annual herbs 0.5-2.5 (3) dm high and 0.5-3 dm across; leaves basal, narrowly lanceolate to oblanceolate, the blades $0.5-2 \mathrm{~cm}$ long, 0.8-2 (2.2) $\mathrm{mm}$ wide, hirsute on both surfaces, obtuse apically, gradually tapering to an indistinct, hirsute petiole; inflorescences cymose, dichotomously branched throughout; bracts usually 2 , opposite, similar to the leaves only reduced at the lower nodes, typically with a whorl of 3-5 about midlength along the stem, 0.5-2 (3) $\mathrm{cm}$ long and 1-3 (4) $\mathrm{mm}$ wide, short petiolate, linear and aciculate above, acerose; involucres congested in small bracteate terminal clusters, the tube cylindrical and slightly ventricose basally, 3-angled but 6-ribbed, 3-4 mm long, finely corrugated, hispid at least along the ridges, otherwise sparsely pubescent, tannish, with a conspicuous, broad, white, membranaceous margin typically extending up the tooth to the awn, the teeth spreading, all the same size, 1-1.5 mm long, the straight awns 0.5-1 mm long; flowers well exserted beyond the involucre, cylindric, 4-4.5 (5) $\mathrm{mm}$ long, the tube cream, the lobes creamy-white to rose, slightly pubescent without nearly the whole length of the midrib with the hairs not extending to the apex of the tepals, on pedicels $0.3-0.5 \mathrm{~mm}$ long, the tepals monomorphic, obovate, obcordate to bilobed apically, slightly irregular but not distinctly erose, united about two- 
thirds of their length; stamens 9, slightly exserted, the filaments $4-5 \mathrm{~mm}$ long, glabrous, the anthers 0.5-0.6 mm long, oblong, pink to red; achenes light brown, 3.5-4.5 mm long; $n=19$, 20, 22 (Hardham 1969).

Sandy to gravelly places mainly in the foothills bordering the Central Valley of California from Shasta Co. south to Stanislaus Co. on the western side, and to Tulare Co. on the eastern side, from 100-2700 ft elev; flowering from (Apr) May-Jun (Jul).

Representative Specimens: UNITED STATES. CALIFORNIA: Butte Co.: without location data, Jun 1879, Austin s.n. (GH, ISC, NY, VT); 5 mi E of Chico, 25 May 1941, Heller 16150 (MO, NY, WTU); Chico, May 1882, Parry s.n. (F, GH, ISC, NY, SD, US, VT). Calaveras Co.: Wallace, 4 Jun 1914, McMurphy s.n. (DS, SBBG). Contra Costa Co.: Mt. Diablo, May 1883, Parry s.n. (F). El Dorado Co.: Simpson's Ranch, Sweetwater Creek, 29 May $1907, K$. Brandegee s.n. (MO, POM, UC); $4.8 \mathrm{mi} \mathrm{W}$ of Rescue at W end of Green Valley, 25 May 1933, Wolf 4964 (CAS, RM, RSA, UC, WS, WTU). Fresno Co.: Toll House, 13 Jun 1900, Hall \& Chandler 30 (MIN, UC); $0.4 \mathrm{mi}$ W of Dunlap, 27 Jun 1933, Wolf 5067 (CAS, RSA, SD, UC, WS, WTU). Lake Co.: Kelseyville, 8 Jun 1929, Blankinship s.n. (MO). Madera Co.: San Joaquin Experiment Station, 3 May 1938, Biswell 168 (NEB, UC, USFS); Raymond, 8 May 1938, Eastwood 12558 (CAS, K, ORE, POM, SBBG); near Raymond on road to Coarsegold, 29 May 1938, Hoover 3517 (DS, K, LL, MICH, NY, UC, US); Fresno Flat, 20 May 1928, Jepson $12836 a$ (JEPS, LE, UT); 7.6 mi S of Coarsegold on California Highway 41, 7 May 1963, Raven 18338 (B, CAS, MO, RSA). Mariposa Co.: Chapman District, 25 Apr 1896, Congdon s.n. (MIN). Merced Co.: Merced foothills, May 1887, Buckminster s.n. (COLO, F, MIN, UC). Sacramento Co.: near Folsom, 1884, Curran s.n. (F). Shasta Co.: 3 mi E of Redding, 30 May 1905, Heller $7910 a$ (GH, MO, NY, PH, US); 3 mi E of Redding, 17 May 1940, C.L. Hitchcock 6438 (NY, OKL, POM, UC, WTU). Stanislaus Co.: West Fork of Upper Dominici Creek, $1.5 \mathrm{mi}$ W of La Grange, 8 May 1969, P.S. Allen 280 (DAV, WTU); Gobin Ranch, 13 mi E of Waterford, 16 May 1937, Hoover 2141 (DS, K, NY, UC, US, UTC). Sutter Co.: Marysville Butte, 17 May 1902, Heller \& Brown 5568 (B, DS, E, F, G, GH, L, LE, MO, NY, PH, POM, US). Tehama Co.: $39 \mathrm{mi}$ W of Mineral along California Highway 36, 22 May 1971, Smith \& Sawyer 4635 (BRY, MARY, RSA). Tulare Co.: San Creek Valley, E of Orange Cove, 30 Jun 1937, Hoover 2579 (K, NY, UC, US). Unknown Co.: without location data, 1853-1854, Bigelow s.n. (GH, K, NY, PH, US); without location data, 1882 , Parry s.n. (BM, F, G, ISC, LE, NEB, ORE, UC). A total of 86 collections are known to us.

The range of Chorizanthe stellulata (from Latin stellulatus, starry, alluding to the star-like appearance of the white-margined involucre) is essentially north of that of $C$. douglasii, and while the distinction between the two species is sometimes difficult in exceedingly old or poorly preserved specimens, the two can be readily distinguished by their geographic ranges. The color of the membranaceous margins is diagnostic in separating the two, as is the type of pubescence found on each, but otherwise the species are morphologically rather similar.

4. Chorizanthe douglasii Benth., Trans. Linn. Soc. London 17: 418. 1836.-TYPE: Without location data, but probably from the Santa Lucia Mountains, Monterey Co., California, “1833," Douglas s.n. (holotype: K!; isotypes: BM, BR, CGE, E, GH, ISC, K, LE, MO!).

Chorizanthe nortonii E. Greene, Pittonia 2: 164. 1891. - TYPE: Palisades and Chalone peaks, near Gonzales, San Benito Co., California, May 1891, Norton s.n. (holotype: CAS!; isotypes: DS, NDG, UC!).

Erect, villous annual herbs 1-4 (5) dm high and 0.5-3 dm across; leaves basal, oblanceolate, the blades $0.5-2$ (4) $\mathrm{cm}$ long, 1-4 (10) $\mathrm{mm}$ wide, villous on both surfaces, obtuse apically, gradually tapering to a hirsute petiole $1-3(6) \mathrm{cm}$ long; inflorescences cymose, dichotomously branched throughout; bracts usually 2 , opposite, similar to the leaves only reduced at the lower nodes, typically with a whorl of 3-5 about midlength along the stem, $0.5-2$ (3) $\mathrm{cm}$ long and 1-5 (10) $\mathrm{mm}$ wide, short petiolate, linear and aciculate above, acerose; involucres congested in small leafy terminal clusters, the tube cylindrical and slightly ventricose basally, 3-angled but 6-ribbed, 3-5 mm long, finely corrugated, hispid at least along the ridges, otherwise sparsely pubescent, greenish, with a conspicuous, broad, purple, membranaceous margin 
typically extending across the sinuses, the teeth spreading, all the same size, (0.7) $1-1.5 \mathrm{~mm}$ long, the straight awns 0.5-1 mm long; flowers well exserted beyond the involucre, cylindric, 3.5-4 (4.5) $\mathrm{mm}$ long, white to rose, slightly pubescent without nearly the whole length of the midrib with the hairs not extending to the apex of the tepals, on pedicels $0.3-0.5 \mathrm{~mm}$ long, the tepals monomorphic, obovate, bilobed or denticulate apically, infrequently the inner whorl entire, united about two-thirds of their length; stamens 9, slightly exserted, the filaments 3-4 $\mathrm{mm}$ long, glabrous, the anthers $0.5-0.6 \mathrm{~mm}$ long, oblong, pink to red; achenes light brown, 3.5-4 mm long; $n=20$ (Hardham 1989).

Sandy to gravelly places on the crest and eastern slope of the Santa Lucia Mountains east across the intervening low hills to the San Gabilan and La Panza ranges of San Benito and Monterey cos. south to central San Luis Obispo Co., California, from (700) 1000-5000 ft elev, flowering from Apr-Jul.

Representative Specimens: UNITED STATES. CALIFORNIA: Monterey Co.: Carmel Highlands, opposite Yankee Point, 14 Aug 1963, Balls 12077 (BM, DAO, RSA); Arroyo Seco Camp, Santa Lucia Mountains, 6 Jun 1956, Bechtel s.n. (ARIZ, CM, DAO, DAV, LA, MIN, RSA, UC, UTC); $8.3 \mathrm{mi}$ SE of Arroyo Seco Guard Station, Santa Lucia Mountains, 7 Jul 1962, Breedlove 3784 (DS, UCSB); S base of hill at school, Hastings Reservation, 26 Apr 1947, Cook \& Cook 682 (B, CAS, COLO); Tassajara Hot Springs, Santa Lucia Mountains, Jun 1901, Elmer 3253 (DS, G, K, MIN, US, Z); near The Indians, Santa Lucia Mountains, 13 May 1980, Ertter \& Strachan 3370 (ASU, BRY, CAS, CPH, MARY, NY, SD, UTC); Pine Canyon, SW of Salinas, 13 May 1961, Hardham 6995 (CAS, RSA, SBBG, UCSB, UT); ridge above Posts near Big Sur, Apr 1937, F.W. Hoffman 1178 (B, ISC, W); near The Indians, Santa Lucia Mountains, 24 May 1933, Holman s.n. (B, GH, K, LE, MICH, MO, NY, POM, UC, US); lower Paloma Creek, 4 Jun 1939, Hoover 4124 (DS, K, LL, MICH, NY, UC, US, UTC, WS); Rancho del Monte, Carmel River, 7 May 1921, Mason s.n. (DS, RM, UC, US); trail to Cone Peak, Santa Lucia Mountains, 18 Jun 1955, Munz 20939 (CAS, NY, RSA, UT); without location, Jun 1891, Norton s.n. (B, CAN, CAS, DS, F, K, LE, NY, PH, US); 1 mi S of Chews Ridge Road, Santa Lucia Mountains, 23 Jun 1978, Reveal 4757 (CAS, MARY, MO, NY, OKL, RSA); Jolon, 6 May 1963, Rose 63024 (ARIZ, B, BR, BRY, CAS, COLO, DAO, DS, G, MICH, MIN, OBI, RM, RSA, SMU, TEX, WIS); Carmel River, 20 mi W of Carmel, 21 Jul 1929, Wolf 3771 (CAS, GH, MARY, RSA, SD, UC, US, WTU). San Benito Co.: San Benito, 16 May 1918, Eastwood 6948 (CAS, RSA, UC, US); San Benito River near Merrill Valley (Loco Flat), 24 May 1915, H.M. Hall 9922 (E, UC, US); N of the Pinnacles Post Office and school, 31 May 1946, Hoover 6096 (OBI, OKL); The Pinnacles National Monument, 19 May 1937, Rose 37286 (GH, MO, OKL, RM, RSA, WTU). San Luis Obispo Co.: 5.7 mi E of Santa Margarita, Parkhill Road, 25 May 1955, Bacigalupi et al. 5234 (DS, JEPS, OBI); 7 mi E of La Panza, 8 May 1936, Eastwood \& Howell 2331 (CAS, US); Moreno Creek, 4 mi E of Santa Margarita, 25 May 1955, Ferris 12824 (DS, NY, RSA, WTU); hills between Bee Rock and Nacimiento River, 6 May 1959, Hardham 4396 (RSA, SBBG, UC, UCSB); Pilitas Creek District, 20 Apr 1947, Hoover 6969 (CAS, DAO, OBI, UC); Moreno Creek, near Salinas River, E of Santa Margarita, 4 Jun 1967, Hoover 10620 (CAS, DAO, OBI, OSC, UC); N of Nick Ranch on road to Pine Mountain Spring, S of Sycamore Canyon, 14 May 1982, Luckow \& Riggins 865 (ASU, OBI, UCR); Red Eagle Mine, $1 \mathrm{mi}$ E, 12 mi S of Shandon, 5 May 1952, McMillan 98 (CAS, DAO, OBI); along California Highway 58, 0.6 mi E of San Juan Creek between La Panza and Carrisa Plains, 26 May 1988, Reveal 6905 (BRY, CAS, MARY, MO, OSC, RSA, WIS); along California Highway 58, $2.1 \mathrm{mi}$ W of Shell Creek Road, 26 May 1988, Reveal 6913 (CAS, MARY, MO, RM, RSA, US); 8 mi E of La Panza, 8 May 1936, Rose 36260 (F, GH, K, MICH, NY, UC, VT, WS); Mariana Creek, La Panza Mountains, 27 May 1955, Twisselmann 2024 (CAS, RSA); El Dorado School, Santa Margarita, 11 May 1933 , M.E. Wall s.n. (CAS, GH, MO, OKL, US). A total of 159 collections are known to us.

The identity of Chorizanthe douglasii (David Douglas, 1798-1834, a Scotish collector for the Royal Horticultural Society in northwestern America) was initially of some concern to California botanists. Jepson (1913) maintained the species "with misgivings" citing only a single specimen (Clemens s.n., dated 1907). His confusion was largely brought on by Parry's (1884) misapplication of the name to large inland specimens similar to the type of Bentham's (1836) C. douglasii var. hartwegii, a synonym of $C$. robusta. This error was compounded further by Parry who based his description of $C$. robusta on the coastal expression and failed to associate the more inland expression with his new species. Poor Jepson, not knowing what to do with specimens of what we call here $C$. pungens var. hartwegiana, had no choice but to place them 
in his concept of $C$. pungens, but cited not a single representative of var. hartwegiana after having done so.

As an aside of historical interest one should mention that the 1907 Clemens specimen cited by Jepson (1913) as representative of Chorizanthe douglasii is actually a collection of C. stellulata. J. T. Howell has annotated the sheet, now at CAS, indicating that it was mislabelled as having been collected in Monterey Co. We concur.

The bulk of specimens now attributed to Chorizanthe douglasii were assigned by Jepson (1913) to C. nortonii. When Greene (1891) proposed the species, he too was influenced by Parry (1884), and having not seen the type of $C$. douglasii merely accounted for a series of specimens that he felt were without a name. It was Goodman (1934) who finally determined the current, and correct, concept of $C$. douglasii.

IVA(2). Chorizanthe Benth. ex R. Br. subsect. Pungentes Goodman, Ann. Missouri Bot. Gard. 21: 35. 1934.-TYPE: Chorizanthe pungens Benth., according to Art. 22.4 of the ICBN.

Plants prostrate, decumbent, spreading or infrequently erect; leaves basal or nearly so, oblanceolate to broadly obovate; bracts at the lower nodes foliaceous and similar to the leaves, scalelike above; involucres cylindrical, villous, with or without a scarious margin, the margin occasionally conspicuous but never extending across the sinuses, the teeth of two sizes, awned; flowers white to rose, partially exserted from the involucre, slightly pubescent without, the tepals entire to slightly erose or cuspidate apically, both whorls of essentially the same length or the inner one slightly shorter; stamens 3-9, attached at the base of the tepals.

A taxon of coastal California extending into the adjacent foothills and mountains in the central part of the State. from 10-1500 (2500) ft elev; flowering Apr-Aug.

\section{Key to the Species}

A. Involucral teeth uncinate or if straight then the longest ones less than $1.5 \mathrm{~mm}$ long and the involucres without distinct scarious margins; plants of Marin and Sonoma cos. southward.

B. Tepals entire apically, the flowers distinctly bicolored with a lemon-yellow tube and white lobes, glabrous, 2.5-3 mm long; involucral tube with a distinct scarious margin; stamens 3-9; foothills and mountains of the Coast Ranges from Santa Cruz and Monterey cos. southward through San Luis Obispo to western Santa Barbara Co. 5. C. diffusa

BB. Tepals erose to cuspidate apically, the flowers white to rose, pubescent, $2-3(3.5) \mathrm{mm}$ long; involucral tube with or without a scarious margin; stamens $3,6-9$.

C. Plants prostrate or decumbent to ascending, mostly less than $2.5 \mathrm{dm}$ high; involucres $1.5-2.5$ (3) $\mathrm{mm}$ long, with or without a scarious margin.

D. Tepals erose apically, not cuspidate; involucral teeth uncinate; Santa Cruz and Monterey cos. south to Santa Barbara Co.

E. Involucres distinctly margined, the margin white or pink to purplish, the tube 2-2.5 (3) $\mathrm{mm}$ long, the anterior awn 2-3 mm long; flowers 2-3.5 mm long; stamens 9; coastal beaches and inland mountains of Monterey and Santa Cruz cos.

6. C. pungens

EE. Involucres not margined, or if so, then the margin pinkish but hardly conspicuous, the tube 1.5-2 (2.5) mm long, the anterior awn 1.5-2.5 mm long; flowers 2-3 mm long; stamens 3 or 6-9; coastal mesas and foothills of San Luis Obispo and Santa Barbara cos.

7. C. angustifolia

DD. Tepals cuspidate, pubescent the entire length with the hairs usually extending beyond the apex; involucres $1.5-3 \mathrm{~mm}$ long, the awns uncinate or straight, with or without a scarious margins, the anterior awn 2-3 mm long; flowers 2-3 mm long; San Francisco peninsula from northern San Mateo Co. northward to Marin and Sonoma cos. 8. C. cuspidata 
CC. Plants erect or if decumbent then involucres 3-4 mm long and bordered with a conspicuous white margin, up to $5 \mathrm{dm}$ high; involucres $2.5-4 \mathrm{~mm}$ long, with a white to pink or purplish scarious margin; tepals erose to denticulate or distinctly cuspidate; on the immediate coast in Santa Cruz and extreme northern Monterey cos., inland into the foothills and mountains of Santa Cruz, Santa Clara and San Mateo cos. and along the Salinas River in northern Monterey Co., disjunct near Alameda (now extirpated), Alameda Co.

9. C. robusta

AA. Involucral teeth straight, the longer ones 1-2 mm long; involucres with distinct scarious margins; plants of Marin and Sonoma cos. northward.

B. Flowers (3) $3.5-4.5 \mathrm{~mm}$ long, the tepals pubescent nearly their entire length; involucral teeth tannish; plants spreading to decumbent; coastal sand dunes, Mendocino Co.

10. C. howellii

BB. Flowers (4) 5-6 mm long, the tepals pubescent only along the lower half; involucral teeth bright ivory or straw-colored; plants erect to spreading; grassy areas on sandy soil in Marin and Sonoma cos.

11. C. valida

The subsect. Pungentes (from the Latin pungens, sharp, alluding to $C$. pungens a member of the subsection) was considered by Goodman to be his basal unit among those species of Chorizanthe that we have circumscribed as the subg. Amphietes, with $C$. stellulata and $C$. douglasii positioned within the subsection after the $C$. pungens complex. We have placed $C$. douglasii and $C$. stellulata in the sect. Legnota, excluding these species from Goodman's subsect. Pungentes. In addition we have reversed the order of the two species complexes. The more primitive type of inflorescence of the subsect. Legnota accounts for our action.

In our evaluation of the Chorizanthe pungens complex, we have positioned $C$. diffusa as the primary unit rather than $C$. pungens as suggested by Goodman. The trend we follow here is one from a glabrous to a pubescent flower, and a gradual reduction in the prominence of the involucral margin. The subsect. Pungentes is basically a taxon of coastal expressions with the more advanced species exhibiting little or no geographic overlap. Specimens of $C$. diffusa occur with individuals of $C$. pungens and $C$. angustifolia, but the latter two species have allopatric ranges. Specimens of $C$. robusta occur with $C$. pungens and $C$. cuspidata, but again the latter two do not have overlapping ranges. To the north, specimens of $C$. cuspidata var. villosa can be found on the Point Reyes Peninsula growing near $C$. valida, but the two are restricted to adjacent microhabitats.

In several of the species there are distinctive coastal and inland expressions although the variation is clinal in nearly all instances. In Chorizanthe pungens, however, the two forms are taxonomically distinguishable, with the coastal one (var.pungens) differing from the montane one (var. hartwegiana) in the nature of the involucral margin. The coastal expression of $C$. robusta is generally decumbent to prostrate while the more inland forms are generally upright and erect. As we shall discuss below, however, there may be additional factors influencing our observations other than mere geography. The coastal expression of $C$. valida, for example, is shorter and more colorful than the inland expression, and the more northern populations of $C$. diffusa generally have a less obvious involucral margins than those in the southern part of the range of the species although both extremes are found near the coast as well as in the coastal foothills.

The involucral margin of Chorizanthe membranaceae and $C$. douglasii extends across the space between the tips of the awns so that the membranaceous margin is continuous and forms a flattened surface. In $C$. stellulata the wide membranaceous involucral margin extends across the base of the teeth and up to the awns but not across the gulf between the awns as in the afore mentioned species. In species of the subsect. Pungentes, such as $C$. diffusa for example, the scarious margin extends upwardly along the awn from the body of the tooth. The width of the margin varies from exceedingly narrow (so that it inconspicuous) to exceedingly broad, but in no instance does the margin expand to fill in the gap between the 
awns. In other species, and we can mention C. angustifolia as an example. Here the margin is found mainly along the upper portion of the involucral tooth, extending up and onto the awn in some. In $C$. valida the teeth are erect and terminated by long awns. However, the scarious membrane is positioned between the teeth, and because the involucral teeth deeply divide the tube, the scarious portion is extensive but unlike that found in $C$. diffusa.

5. Chorizanthe diffusa Benth. in A. DC., Prodr. 14: 26. 1856. Chorizanthe pungens Benth. var. diffusa (Benth. in A. DC.) C. Parry, Proc. Davenport Acad. Nat. Sci. 4: 60. 1884. - TYPE: dry sandy plains near Monterey, Monterey Co., California, 1847, Hartweg 1938 (holotype: $\mathrm{K}$ !; isotypes: $\mathrm{BM}, \mathrm{G}, \mathrm{GH}, \mathrm{K}, \mathrm{OXF}$ !)

Chorizanthe pungens Benth. var. nivea Curran, Bull. Calif. Acad. Sci. 1: 274. 1885. Chorizanthe nivea (Curran) A. Heller, Cat. N. Amer. Pl. ed. 3, 96. 1910.-Chorizanthe diffusa Benth. in A. DC. var. nivea (Curran) Hoover, Leafl. W. Bot. 10: 342. 1966. - TYPE: mountains near San Luis Obispo, San Luis Obispo Co., California, Jul 1885, Curran s.n. (holotype: CAS!; isotypes: GH, ISC, K, L, NESH, PH, POM, UC!).

Chorizanthe andersonii C. Parry, Proc. Davenport Acad. Nat. Sci. 5: 175. 1889. - TYPE: Ben Lomand, Santa Cruz Mountains, Santa Cruz Co., California, 1888, Parry 21/2 (holotype: ISC!; isotypes: GH, NY, US!).

Spreading, decumbent, prostrate or rarely slightly erect, villous annual herbs $0.3-1$ (1.5) $\mathrm{dm}$ high and 0.5-2 (10) dm across; leaves basal, oblanceolate, the blades 0.3-2 cm long, 1-4 $\mathrm{mm}$ wide, villous on both surfaces but usually more densely so below, acute apically, gradually tapering to a villous petiole $0.2-1.8$ (2) $\mathrm{cm}$ long; inflorescences rather dense with the secondary branches suppressed; bracts 2, opposite, similar to the leaves only more reduced at the lower nodes, 0.3-2 cm long and 1-4 mm wide, short petiolate, becoming linear and aciculate above, acerose; involucres solitary, the tube cylindrical, 3-angled but 6-ribbed, 2-2.5 mm long, villoushirsute with spreading hairs, with a thin to conspicuous and broad white scarious margin extending nearly the full length of the awn, the teeth spreading to divergent, the uncinate awns of two size classes, the larger ones $1-2 \mathrm{~mm}$ long with the anterior one mostly $2 \mathrm{~mm}$ long, alternating with the smaller ones 0.5-1 mm long; flowers exserted beyond the involucre, campanulate, $2.5-3 \mathrm{~mm}$ long, bicolored with the tube lemon-yellow and the lobes white, glabrous, on pedicels $0.3-0.5 \mathrm{~mm}$ long, the tepals monomorphic, oblong, acute to obtuse and entire apically, united about one-thirds of their length; stamens 3-9, slightly exserted, the filaments 1.5-2 mm long, glabrous, the anthers 0.3-0.4 mm long, oval, yellow; achenes dark brown, 2-2.5 mm long; $n=19-21$ (Hardham 1989).

Sandy to gravelly places near the coast and in the Coast Ranges from Santa Cruz and Monterey cos. southward through San Luis Obispo Co. to Santa Barbara Co., from 100-2500 ft elev, flowering from Apr-Jul.

Representative Specimens: UNITED STATES. CALIFORNIA: Monterey Co.: Seaside, 29 May 1912, Eastwood 151 (CAS, GH, UC); near Del Monte, 16 Jun 1938, Eastwood \& Howell 6039 (CAS, F, ISC, POM, SBBG, UC, US, WTU); San Ardo, 14 Jun 1963, Hardham 10819 (RSA, SBBG, UCSB); along the railroad near Seaside, 19 May 1903, Heller 6750 (B, BKL, DS, E, F, G, GH, ISC, L, LE, MIN, MSC, NDG, NY, PH, POM, RM, UC, US); Monterey, 27 Jun 1927, Heller 14404 (COLO, F, G, MO, PH, UC); near the Monterey Airport on the Salinas Road, 4 mi E of Monterey, 15 Jun 1965, J. T. Howell 41356 (CAS, DAV, NO); in the river bed of the Arroyo Seco River where it joins the Salinas River at Soledad, 18 May 1963, Howitt 1508 (CAS); along the East Ridge Trail, Toro Regional Park, Salinas, 21 May 1977, M.S. Taylor 1347 (CHSC); Manzanita Park near Prunedale, 24 Jun 1984, Yadon s.n. (JEPS). San Luis Obispo Co.: Price Canyon, without date, K. Brandegee 85 (ARIZ, B, BKL, BM, CAN, DS, E, G, GH, K, L, LE, MO, NESH, NMC, NY, ORE, POM, RM, UC, US); Huasna District, 31 May 1962, Hardham 10254 (RSA, SBBG, SD, UCSB); summit at head of Carpenter Canyon, N of Arroyo Grande, 23 Jun 1946, Hoover 6187 (CAS, DS, LL, OBI, OKL, UC, UTC, WS); Arroyo Grande, 5 Jun 1969, Hoover 11368 
(CAS, OBI, RSA, UC); Nipomo Mesa, 20 Jun 1987, Reveal \& Broome 6504 (ARIZ, ASU, BM, BRY, CAS, F, GH, MARY, MICH, MO, NY, RM, RSA, TEX, US, WIS); Nipomo Mesa, 20 Jun 1987, Reveal \& Broome 6505 (CAS, MARY, MICH, MO, NY, RM, RSA, US, WIS). Santa Barbara Co.: junction of California Highway 1 and Signature Road, N of Lompoc, 15 Jun 1960, E.R. Blakley 3485 (CAS, JEPS, RSA, SBBG, UCSB); Point Sal Ridge, 30 Jun 1960, E.R. Blakley 3497 (SBBG); $0.5 \mathrm{mi}$ E of the summit of Harris Grade, N of Lompoc, 12 May 1965, E.R. Blakley 6556 (OBI, RSA, SBBG, SD, UCR); Surf, May 1909, K. Brandegec s.n. (UC); Blockman's Ranch, 13 Jun-3 Jul 1906, Eastwood 465 (GH, NY, SBBG); between Lompoc and Camp Cook, 20 Jul 1953, Ferris \& Bacigalupi 12665 (DAO, DS, UC, WTU); 7 mi W of Buellton, 30 May 1929, Hoffmann s.n. (NO, SBBG); along Burton Hill Mesa Road, 22 Jun 1987, Reveal \& Broome 6526 (CAS, MARY, NY, RSA, TCD); Graciosa Ridge, SE of Orcutt, W of Mt. Solomon, 13 Jun 1973, Tilforth \& Dourley 829 (MICH, RSA). Santa Cruz Co.: Scotts Valley, 187-, Anderson s.n. (E, NY, UC, US); Ben Lomand sand hills, 20 May 1941, Hoover 5126 (K, NY, UC, US); Ben Lomand sandhills, 16 Jun 1939, J. T. Howell 14762 (CAS, ISC, RSA, UC, US); along Graham Hill Road, 2 mi SE of Felton, 31 May 1988, Reveal 6959 (BRY, CAS, MARY, OSC, RSA, WIS); Saratoga Gate to Big Basin, 17 Jun 1935, Rose 35227 (CAS, MICH, RSA, UC); Mt. Hermon, 10 Jun 1959, Rose 59022 (BRY, CAS, COLO, DS, G, RSA); 4 mi NW of Boulder Creek, 15 Jul 1953, Thomas 3480 (DS, US); W of Scott Valley, 28 Jul 1934, Yates 4038 (USFS, RSA, UC). A total of 155 collections are known to us.

There are two expressions within Chorizanthe diffusa (from the Latin diffusus, diffuse, alluding to the branching pattern of the inflorescence) that, at their extremes, are markedly distinct. The generally more northern form (var. diffusa) has a thin and nearly indistinct involucral margin while the more southern form (var. nivea) generally has a broad, white conspicuous margin. Jepson (1913) initially followed Parry (1884) who maintained the var. diffusa in $C$. pungens, a view accepted by Curran when she proposed the var. nivea. Parry had also reduced $C$. cuspidata to the varietal rank under $C$. pungens, and Jepson expanded the concept of that species in 1913 by reducing $C$. robusta as well. In 1923 Jepson continued to circumscribe $C$. pungens in a broad sense, but removed var. nivea and elevated it to the species rank. Apparently, Jepson was unaware that Heller (1910) had proposed the same combination more than a decade before.

When Goodman (1934) considered the complex, he disassembled Chorizanthe pungens recognizing several species, notably $C$. cuspidata, C. angustifolia, C. diffusa, C. villosa and $C$. robusta, all expressions Jepson referred to that species. Goodman did not distinguish between the var. diffusa and var. nivea, considering the supposed difference in habit ("erect" versus "decumbent") noted by Jepson (1923) not to be significant. Hoover (1966) distinguished the two expressions much as Curran (1885) had intended. However, he noted in a suite of herbarium specimens collected on the Nipomo Mesa in southern San Luis Obispo Co., that the two freely intergraded (Hoover 9181-9184, CAS, OBI, UC). And indeed this is true (see Reveal \& Broome 6504 and 6505), not only at this location but elsewhere as well.

Our initial reaction was to follow Hoover (1966) and continue to recognize the extremes at the varietal rank. However, as we reviewed specimens from throughout the range of the species, it became more and more difficult to maintain the distinction and at this point we are returning to Goodman's (1934) position and not attempting to distinguish varieties.

\section{Chorizanthe pungens Benth.}

Prostrate to ascending or erect, grayish-villous annual herbs 0.5-2 (2.5) dm high and 0.5-10 $\mathrm{dm}$ across; leaves basal, oblanceolate, the blades (0.5) 1-5 (7) cm long, (3) 4-7 (10) mm wide, villous on both surfaces, rounded apically, gradually tapering to a villous petiole (0.5) 1-3 (4) $\mathrm{cm}$ long; inflorescences rather dense with the secondary branches suppressed; bracts 2, opposite, similar to the leaves only more reduced at the lower nodes, $0.5-7 \mathrm{~cm}$ long and 2-7 $\mathrm{mm}$ wide, short petiolate, becoming linear and aciculate above, acerose with the awns $0.5-1.2$ $\mathrm{mm}$ long; involucres solitary, the tube cylindrical and often ventricose basally, 3-angled but 
6-ribbed, 2-2.5 (3) $\mathrm{mm}$ long, villous, corrugate, with a distinct white to pink or purple scarious margin extending nearly the full length of the awn, the teeth spreading, the uncinate awns of two size classes, the larger ones $2-3 \mathrm{~mm}$ long with the anterior one mostly $3 \mathrm{~mm}$ long, these alternating with the smaller ones $1-1.5 \mathrm{~mm}$ long; flowers exserted beyond the involucre, cylindric, 2-3.5 mm long, the tube white, the lobes white to rose, pubescent without especially along the midribs, on pedicels $0.2-0.3 \mathrm{~mm}$ long, the tepals monomorphic, obovate to oblong, acute to truncate and erose apically, united less than a quarter of their length; stamens 9, slightly exserted, the filaments $2-3 \mathrm{~mm}$ long, glabrous, the anthers $0.3-0.4 \mathrm{~mm}$ long, oval, cream to rose; achenes dark brown, $2-2.5 \mathrm{~mm}$ long; $n=20$.

Sandy places on and near the coast and in the Coast Ranges of Santa Cruz and Monterey cos., from near sea level to $1500 \mathrm{ft}$ elev, flowering from Apr-Jul.

\section{Key to the Varieties}

A. Involucral lobes with white (rarely pinkish) scarious margins; plants prostrate to slightly ascending; coastal areas and inland into Salinas Valley. 6a. var. pungens

AA. Involucral lobes with dark pinkish to purple scarious margins; plants slightly ascending to erect; Santa Cruz Mountains. 6b. var. hartwegiana

6a. Chorizanthe pungens Benth., Trans. Linn. Soc. London 17: 419. 1836, var. pungens.TYPE: Without location data, but most certainly found near Monterey, Monterey Co., California, "1833," Douglas s.n. (holotype: K!; isotypes: BM, CGE, GH, K, LE, OXF!).

Chorizanthe douglasii Benth. var. albens C. Parry, Proc. Davenport Acad. Nat. Sci. 5: 175. 1889. - TYPE: Salinas Valley, Monterey Co., California, 20 Apr 1888, Parry s.n. (holotype: ISC!; isotypes: MIN, MO, NEB, NY, UC, US!).

Plants prostrate or slightly ascending, 0.5-1.5 dm high and 0.5-10 dm across; involucres with white (rarely pinkish) scarious margins; $n=20$ (Hardham 1989).

Sandy places on and near the coast from Monterey Peninsula of Monterey Co. northward to extreme southern Santa Cruz Co., California, and inland into the Salinas Valley, historically reported near San Simeon in extreme northern San Luis Obispo Co., from near sea level to $200 \mathrm{ft}$ elev, flowering from Apr-Jun.

Representative Specimens: UNTTED STATES. CALIFORNIA: Monterey Co.: Rockspur, between Castroville and Monterey, 16 Jun 1908, K. Brandegee s.n. (ARIZ, L, NESH, POM, RM, UC); Pacific Grove, 30 Apr 1932, Demaree 9058 (MIN, ND, OKL, WTU); Seaside, 29 May 1912, Eastwood 150 (GH, NY, UC, US); 11 mi N of Salinas, 5 May 1936, Eastwood \& Howell 2182 (CAS, F, MICH, US); Del Monte, Apr 1902, Elmer 3570 (BKL, CAS, COLO, DAO, DS, E, G, GH, K, MICH, MIN, NY, SBBG, SMU, UC, US, VT, WTU, Z); Monterey, 1846, Hartweg 1936 (BM, BR, CGE, G, GH, K, LE, OXF); along the railroad near Seaside, 19 May 1903, Heller 6749 (BKL, DS, E, F, G, GH, ISC, L, LE, MICH, MIN, NDG, NY, ORE, PENN, PH, POM, RM, UC, US, WIS, WTU); S of Point Pinos, Pacific Grove, 24 May 1941, Hoover 5223 (NY, UC, US); Arroyo Seco near Mission Soledad, 6 Apr 1920, Jepson 8431 (JEPS); Del Monte, 23 Jun 1923, Mason 565 (DS, GH, MIN, NY, POM, UC); Pacific Grove, 8 Jul 1914, Newell s.n. (BM, CAS, GH, NY, US); Monterey, 16 Jul 1882, Pringle s.n. (F, G, MO, NY, PENN, PH, US); along California Highway 218 near Del Rey Oaks, 30 May 1988, Reveal 6951 (BRY, CAS, MARY, MEXU, MO, NY, OSC, RM, RSA, US, UTC, WIS); Marina, 30 May 1988, Reveal 6952 (BRY, CAS, MARY, MO, NY, OSC, RM, RSA, US, UTC, WIS); along California Highway 218 near Del Rey Oaks, 14 Jun 1987, Reveal \& Broome 6441 (ARIZ, CAS, MARY, MICH, MO, NY, RM, RSA, TCD, US, WIS); Seaside, 8 Jun 1963, Rose 63157 (B, BRY, CAS, COLO, DAO, DS, G, MICH, OBI, RM, RSA, SMU, TEX, WS); Point Pinos lighthouse, 10 Aug 1936 , Wheeler 4346 (CAS, DS, NESH, ND, OKL, POM); Manzanita Park near Prunedale, 24 Jun 1984, Yadon s.n. (JEPS). San Luis Obispo Co.: San Simeon, 1842, Gambel s.n. (GH, K, PH). Santa Cruz Co.: sand dunes near Castroville, 9 Jun 1929, Dearing \& Dearing s.n. (POM, SBBG); Glen Echo, 17 Jun 1896, Jepson s.n. (JEPS, UC); near mouth of Pajaro River between ocean and Watsonville Slough, 16 Apr 1950, Thomas 1598 (DS). A total of 109 collections are known to us. 
The var. pungens (from the Latin pungens, sharp, alluding to the sharp awns on the involucres and bracts) is known today only from Monterey and southern Santa Cruz cos., California, but an early Gambel collection would seem to imply that the species was once as far south as San Simeon in extreme northern San Luis Obispo Co. The species has not been recollected in that county, nor, for that matter, has it been found much below the Monterey Peninsula. Of more concern are the eastern populations of the variety, especially those in the Salinas Valley. Except for a few scattered populations near Prunedale, the majority have not been rediscovered in recent years and given the agricultural development, the species has probably been extirpated from much of the area. The more eastern (and inland) plants tend to be more upright than the coastal form, not as large, and generally with a less conspicuous involucral margin. These plants were distinguished as the var. albens by Parry (1889).

The distinction between Chorizanthe pungens var. pungens and $C$. diffusa is sometimes difficult. For the most part this is not the case near the coast, but in the Salinas Valley, a demarcation is not always clear.

6b. Chorizanthe pungens Benth. var. hartwegiana Rev. \& Hardham, var. nov.-TYPE: along Graham Hill Road, $1.7 \mathrm{mi}$ SE of California Highway 9 at Felton, Santa Cruz Mountains, Santa Cruz Co., California, on sandy soil associated with Pinus and Arctostapliylos at about $650 \mathrm{ft}$ elev, 31 May 1988, Reveal 6956 (holotype: MARY!; isotypes: BM, BR, BRY, CAS, CLEM, G, K, KW, LE, MEXU, MO, NY, OKL, OSC, RM, RSA, SMU, US, VT, WIS, Z!).

A var. pungens involucris marginibus purpureis differt.

Plants slightly ascending to erect, 0.5-2.5 dm high and 0.5-10 dm across; involucres with pinkish to purple scarious margins; $n=20$.

Sandy places in the Santa Cruz Mountains mainly in the Ben Lomand sand hills area, Santa Cruz Co., California, from $300-1500 \mathrm{ft}$ elev, flowering from (Apr) May-Jul.

Representative Specimens: UNITED STATES. CALIFORNLA: Santa Cruz Co.: Ben Lomand, May 1903, Elmer 4671 (DS, E, G, MIN, NY, UC, WIS, Z); between Ben Lomand and Zayante, 18 May 1946, Ferris 11133 (DS, GH, IDS, RM, TEX); Ben Lomand sand hills, 20 May 1941, Hoover 5120 (DS, K, NY, UC, US, UTC); Santa Cruz, 1 Jul 1881, M.E. Jones 2327 (BM, DS, G, LE, MSC, POM, UTC, WU); Santa Cruz, 1888, Parry s.n. (F, G, ISC, MIN, NY); Santa Cruz Mountains, 26 Jul 1882, Pringle s.n. (CAS, F, G, GOET, MIN, NMC, NY, PH, SMU, US, VT); along Quail Hollow Road, $0.4 \mathrm{mi}$ NW of Quail Hollow Ranch, 31 May 1988, Reveal 6960 (BM, BRY, CAS, G, MARY, MO, NY, OSC, RM, RSA, US, UTC, WIS); E of the junction of Glen Arbor Road and Quail Hollow Road, 12 Jun 1987, Reveal \& Broome 6424 (ARIZ, ASU, BM, BRY, CAS, F, GH, K, MARY, MICH, MO, NY, RM, RSA, TCD, TEX, US, UTC, WIS); Ben Lomand, 20 Jun 1933, Rose 33235 (B, BRY, CAS, DS, GH, F, LA, LE, MICH, MO, MONTU, ND, OKL, RM, RSA, UC, US, VT, W, WTU); Boulder Creek, 7 May 1939, Rose 39104 (B, G, GH, ISC, MO, NMC, NY, OKL, RSA, TEX, UC, US, UTC, WS, WTU); Mt. Hermon, 10 Jun 1959, Rose 59021 (DS, E, MICH, MIN, RM, RSA, TEX, WS). A total of 75 collections are known to us.

The plant described here as var. hartwegiana (Karl Theodore Hartweg, 1812-1871, German collector in México and California sponsored by the London Horticultural Society) was initially distinguished by Goodman (1934) who associated Bentham's (1856) C. douglasii var. hartwegii with the plant transferring it to $C$. pungens. We concurred initially and have annotated numerous specimens with Goodman's name. An examination of the Hartweg type at Kew in 1987 raised concern that the plant Bentham circumscribed might not fall into the definition of the variety as we and others have given to the Ben Lomand sand hills plants. Field work in 1988, plus a review of several isotypes, confirmed that the type did not conform with the plant we were calling var. hartwegii. The realization that inland plants of $C$. robusta 
had pinkish scarious involucral margins, and it was this that Hartweg had found, forced us to propose a new variety. We are retaining the association with Karl T. Hartweg's name with the plant as an honor to one of California's best early collectors.

The confusion of var. hartwegiana with Chorizanthe douglasii can now be explained with the realization that Bentham noted the close gross similarity between $C$. douglasii and what we now call $C$. robusta, and specifically his var. hartwegii. That confusion was largely to continue up to Goodman's (1934) revision. The conspicuously margined involucral tube and the tall, erect habit of the two are similar.

A chromosome count of $n=20$ was obtained by Reveal for the var. hartwegiana and is vouchered by Reveal 6956.

The continued recognition of the Santa Cruz Mountain variant of Chorizanthe pungens, even though the features used to make that distinction are weak, is because it and the var. pungens are allopatric.

7. Chorizanthe angustifolia Nutt., Proc. Acad. Nat. Sci. Philadelphia 4: 17. 1848.-TYPE: "Pueblo los Angeles," Los Angeles Co., California, but more likely from Santa Barbara, Santa Barbara Co., Apr 1842, Gambel s.n. (holotype: PH!; isotypes: GH, K!).

Chorizanthe angustifolia Nutt. var. eastwoodae Goodman, Ann. Missouri Bot. Gard. 21: 42. 1934. - TYPE: Morro Bay, San Luis Obispo Co., California, 16 May 1928, Eastwood 15108 (holotype: CAS!).

Decumbent or prostrate, villous annual herbs 0.3-1 dm high and 0.5-10 (13) dm across; leaves basal, oblanceolate, the blades (0.5) 1-4 (5) cm long, (2) 3-6 mm wide, villous on both surfaces, acute apically, gradually tapering to a villous petiole $1-4 \mathrm{~cm}$ long; inflorescences rather dense with the secondary branches suppressed; bracts 2 , opposite, similar to the leaves only reduced at the lower nodes, 1-4 cm long and 2-8 (10) $\mathrm{mm}$ wide, short petiolate, becoming linear and aciculate above, acerose; involucres solitary, the tube cylindrical, 3-angled but 6ribbed, 1.5-2 (2.5) $\mathrm{mm}$ long, villous, without a scarious margin or if so then thin and restricted to the basal portion of the teeth and pinkish, the teeth spreading, the uncinate awns of two sizes, the larger ones $1.5-2.5 \mathrm{~mm}$ long with the anterior one mostly $2-2.5 \mathrm{~mm}$ long, these alternating with the smaller ones $1-1.5 \mathrm{~mm}$ long; flowers slightly exserted beyond the involucre, campanulate, $2-3 \mathrm{~mm}$ long, the tube white, the lobes white to rose, pubescent without along the midribs, on pedicels $0.2-0.3 \mathrm{~mm}$ long, the tepals monomorphic, oblong, usually rounded and erose apically, united about one-thirds of their length; stamens 3, 6-9, slightly exserted, the filaments $2-2.5 \mathrm{~mm}$ long, glabrous, the anthers $0.2-0.3 \mathrm{~mm}$ long, oval, cream to rose; achenes light brown, 2-2.5 mm long; $n=19,20$ (21-23) (Hardham 1989).

Sandy places along the coast in San Luis Obispo and Santa Barbara cos., California, from 50-400 ft elev, flowering from Apr-Jun (Jul).

Representative Specimens: UNITED STATES. CALIFORNIA: San Luis Obispo Co.: W edge of outlet of Oso Flaco Lake, 23 May 1962, E.R. Blakley 5134 (RSA, SBBG, UCSB); S end of Morro Bay, 23 May 1959, Hardham 4613 (CAS, DAO, RSA, SBBG); Baywood Park, 24 Apr 1962, Hardham 9070 (CAS, RSA, SBBG); Arroyo Grande, near the marsh, 18 Apr 1930, Hoffinann s.n. (NY, RSA); S of Hazard Canyon, 11 Jun 1964, Hoover 9035 (CAS, OBI, OKL); 3 mi NW of Nipomo, 11 Jul 1964, Hoover 9179 (CAS, DS, OBI, OKL, UC); Jack Lake, 15 May 1966, Hoover 9855 (CAS, OBI, RSA, UC); Price Canyon, 20 Jun 1987, Reveal \& Broome 6499 (CAS, MARY); 0.2 mi NW of the entrance to Montaña de Oro State Park, San Luis Range, 18 Jun 1987, Reveal et al. 6479 (CAS, MARY, MICH, MO, NY, RSA, TCD, WIS); Oso Flaco Lake, 13 May 1950, Rose 50118 (BRY, CAS, COLO, DAO, RSA, UC, W); Pecho Hills, N of mouth of Hazard Canyon, 23 May 1959, Twisselmann 5271 (CAS, OKL). Santa Barbara Co.: Surf, 23 Apr 1937, Barneby 370/37 (K); near railroad bridge over Santa Ynez River mouth, 28 May 1983, 
Bevier 41 (SBBG); Santa Maria, 13 Jun 1906, Eastwood 351 (CAS, GII, NY); 5 mi S of Surf, 14 Apr 1929, Ferris 7545 (DS, F, POM, UC); between Casmalia and Point Sal, 31 May 1931, Hoffmann s.n. (SBBG); Surf, 20 Apr 1929, Peirson 8310 (CAS, MARY, RSA); La Mesa, W of Victoria Strect, Santa Barbara, 10 May 1956, Pollard s.n. (CAS, MICH, UC); 3.5 mi S of Casmalia, 22 Jun 1987, Reveal \& Broome 6523 (CAS, MARY, NY, RSA). A total of 120 collections are known to us.

It is uncertain where William Gambel, an ornithologist who visited California initially from 1841 to 1843 , actually collected the type specimen of Chorizanthe angustifolia (from the Latin angustus, narrow, and folius, leaf, alluding to the narrow basal leaves). Nuttall (1848) stated the type was collected at "Pueblo los Angeles, Upper California." According to McKelvey (1955), Gambel was in the Los Angeles area in April of 1842, and Santa Barbara in late April and May; it is likely Gambel found the immature plants that make up the type at Santa Barbara where it is still to be found.

Goodman (1934) considered the var. angustifolia to differ from his newly proposed var. eastwoodae in having shorter flowers and only three stamens. In fact this is not the case, but the two do differ in that the var. angustifolia does lack all vestiges of a scarious margin between the involucral teeth while a thin pinkish one is found in the var. eastwoodae. Even so, there is no geographic differentiation between the two phases and it is not uncommon to find mixed populations.

Chorizanthe angustifolia may be found growing with $C$. diffusa in San Luis Obispo and northern Santa Barbara cos. without any indication of hybridization. Except for this species, C. angustifolia does not overlap with any other species in the subsect. Pungentes. By and large C. angustifolia is more densely pubescent compared to the other members of the subsection. Also, this species tends to be restricted to the immediate coast and the adjacent mesas, just entering the first range of foothills to the east.

In the early California floristic literature the name Chorizanthe angustifolia was unaccounted for. It was Goodman (1934) who correctly noted the identity of the fragmentary Gambel type and was able to associate it with a population distinct from but generally confused with $C$. pungens.

\section{Chorizanthe cuspidata S. Wats.}

Decumbent to prostrate or ascending, villous annual herbs 0.5-2 (2.5) dm high and 0.5-10 $\mathrm{dm}$ across; leaves basal, oblanceolate, the blades (0.5) $1-5 \mathrm{~cm}$ long, (3) 4-7 (10) $\mathrm{mm}$ wide, villous on both surfaces, acute apically, gradually tapering to a villous petiole $(0.5) 1-3 \mathrm{~cm}$ long; inflorescences rather dense with the secondary branches suppressed; bracts 2, opposite, similar to the leaves only reduced at the lower nodes, $0.5-5 \mathrm{~cm}$ long and $2-7 \mathrm{~mm}$ wide, short petiolate, becoming narrowly elliptic to linear-lanceolate and aciculate above, acerose with the awns 0.5-1.2 mm long; involucres solitary, the tube cylindrical and often ventricose basally, 3-angled but 6-ribbed, 1.5-3 mm long, villous, corrugate, without a scarious margin or if so then thin, white to pink and restricted to the basal portions of the teeth, the teeth spreading, the uncinate or straight awns of two sizes, the larger ones $2-3 \mathrm{~mm}$ long with the anterior one mostly $2.5-3 \mathrm{~mm}$ long, these alternating with the smaller ones 1-1.5 (1.7) mm long; flowers included to just slightly exserted beyond the involucre, cylindric, 2-3 $\mathrm{mm}$ long, the tube white, the lobes white to rose, pubescent without especially along the midribs with the hairs generally extending beyond the apex of the tepals, on pedicels $0.2-0.3 \mathrm{~mm}$ long, the tepals monomorphic, oblong, truncate to 3-lobed and distinctly cuspidate apically, united less than a quarter of their length; stamens 9, slightly exserted, the filaments $2-3 \mathrm{~mm}$ long, glabrous, the anthers 0.3-0.4 mm long, narrowly oblong, cream to rose; achenes light brown, $2-3 \mathrm{~mm}$ long. 
Sandy places on and near the coast from the San Francisco Peninsula of San Mateo and San Francisco cos. eastward across the San Francisco Bay to western Alameda Co. and northward into Marin and western Sonoma cos., California, from near sea level to $700 \mathrm{ft}$ elev; flowering from Apr-Jul (Aug).

\section{Key to the Varieties}

A. Involucral awns uncinate apically, San Francisco area.

7a. var. cuspidata

AA. Involucral awns straight throughout; Marin and Sonoma cos.

7b. var. villosa

As a species Chorizanthe cuspidata is easy to recognize by its distinctively cuspidate tepals with its slightly exserted flowers that are rather densely pubescent with the hairs generally extending beyond the apex of the tepal. We have seen an occasional specimen of $C$. pungens with a single tepal bearing a cusp, but this condition is rare.

8a. Chorizanthe cuspidata S. Wats., Proc. Amer. Acad. Arts 17: 379. 1882, var. cuspidata. Chorizanthe pungens Benth. var. cuspidata (S. Wats.) C. Parry, Proc. Davenport Acad. Nat. Sci. 4: 60. 1884. - TYPE: San Francisco, San Francisco Co., California, 16 Jul 1881, M.E. Jones 2386 (holotype: GH!; isotypes: BKL, BM, BR, CAS, F, G, GH, K, LE, MO, NY, PH, POM, SMU, US, UTC!).

Chorizanthe cuspidata S. Wats. var. marginata Goodman, Ann. Missouri Bot. Gard. 21: 40. 1934. - TYPE: San Pedro, San Mateo Co., California, May 1903, Elmer 4828 (holotype: MO!; isotypes: ARIZ, BKL, CAS, DS, E, G, MICH, MIN, MO, NY, ORE, OSC, POM, UC, US, WS, Z!).

Plants decumbent to prostrate, 0.5-1.5 dm high and 0.5-10 dm across; leaves with the blades 0.5-2 (2.5) cm long and 3-7 mm wide; involucres $1-2 \mathrm{~mm}$ long, with or without a thin, pinkish scarious margin, the awns uncinate apically; flowers 2-2.5 mm long; achenes 2-2.5 mm long.

Sandy places in the San Francisco Bay region from northern San Mateo and San Francisco cos., California, and historically across the San Francisco Bay eastward to Alameda Co. and northward onto Mt. Tamalpais in Marin Co., from near sea level to $700 \mathrm{ft}$ elev, flowering from Apr-Jul.

Representative Specimens: UNITED STATES. CALIFORNIA: Alameda Co.: Oakland, 1881, Lemmon s.n. (JEPS). Marin Co.: Mt. Tamalpais, 8 Jul 1873, McLean s.n. (UC). San Francisco Co.: near San Francisco, 3 May 1903, C.F. Baker 2842 (B, F, G, GH, K, LE, MICH, MO, NDG, NY, POM, RM, UC, US); San Francisco, 1865, Bolander 112 (F, G, GH, MO); San Francisco, 1905, Brandegee s.n. (DS, NESH, POM, US); Laurel Hill Cemetery, 6 Jun 1912, Eastwood 222 (CAS, GH, NY, UC, US); Lake Merced, 8 Jun 1902, Heller 5666 (BKL, DS, E, F, G, GH, L, LE, MIN, MO, NY, PH, POM, RM, US); S of Sutro Heights, 21 Jun 1930, J. T. Howell 5316 (CAS, LA, POM); San Francisco, 16 Jun 1868, Kellogg \& Harford 6 (BKL, DS, K, MIN, UC, US); San Francisco, 18 Apr 1926, Mason 2871 (DS, GH, MO, NY, UC); Baker Beach, 1 Jun 1950, Raven 2104 (CAS, DAO, ENCB, RSA, UTC); below Olympic Golf Course, 23 Apr 1955, Robbins 3653 (CAS, DS, JEPS); Lake Merced, 22 Jun 1941, Rose 41281 (ARIZ, B, BKL, BM, BR, CAN, CAS, COLO, DAO, DS, E, G, GH, ILL, ISC, K, L, LA, LE, MICH, MIN, MO, MONTU, MSC, ND, NO, NY, OKL, PENN, PH, POM, RM, SMU, TEX, UC, US, UTC, WIS, WS); Presidio, 11 Jul 1958, Rose 58121 (BRY, COLO, DAO, DS, E, G, GH, MIN, NY, RM, RSA, SMU, UC, US); San Francisco, 1865, Torrey 434 (GH, MIN, NY, US); Lake Merced, 15 May 1953, Weber \& Rose 8377 (ARIZ, CAS, COLO, DAO, DS, MIN, POM, TEX, UC, WTU); San Francisco, 19th Avenue at Estero Station, 27 Jun 1934, Wolf 5744 (GH, RSA, WTU). San Mateo Co.: Colma, 11 May 1911, Abrams 1603 (DS, POM, RM); Thornton Beach State Park, Daly City, 24 May 1963, Breedlove 4975 (DS, SMU); Salada, 28 May 1925, W.S. Cooper 12 (JEPS, MIN); Crystal Springs Lake, May 1903, Elmer 4793 (ARIZ, CAS, COLO, DS, E, G, MIN, MO, NY, ORE, POM, UC, US, WS, Z); near the Ocean Shore Railroad tracks, S of Ocean View, 8 Jun 1906, Heller 8383 (BKL, CAS, DS, E, F, G, GH, ISC, L, MIN, NESH, NY, PH, UC, US, WU); Colma Canyon, 13 Jun 1965, McClintock s.n. (CAS). A total of 98 collections are known to us. 
The var. cuspidata (Latin cuspidatus, pointed, alluding to the cusp on the tepals) is restricted to the San Francisco Bay region where it is common on the San Francisco Peninsula. There are two expressions, one with and the other without a margin between the involucral teeth. Goodman (1934) proposed to distinguish them, but as they completely intergrade, we are unable to maintain the distinction.

8b. Chorizanthe cuspidata S. Wats. var. villosa (Eastw.) Munz, Aliso 4: 89. 1958. C. villosa Eastw., Bull. Torrey Bot. Club 30: 485. 1903. - TyPE: Bodega Point, Sonoma Co., California, 4 Jul 1900, Eastwood s.n. (holotype: CAS!; isotypes: GH, NY, UC, US!).

Plants ascending to slightly erect, 0.5-2.5 dm high and 0.5-10 dm across; leaves with the blades $1-5 \mathrm{~cm}$ long and $4-10 \mathrm{~mm}$ wide; involucres (2) $2.5-3 \mathrm{~mm}$ long, without a scarious margin, the awns straight throughout their length, rarely curved or with an individual awn uncinate; flowers 2.5-3 mm long; achenes 2.5-3 mm long; $n=19-21$ (Hardham 1989).

Sandy places on the Point Reyes Peninsula of Marin Co. northward to Bodega Bay, Sonoma Co., California, from near sea level to $200 \mathrm{ft}$ elev, flowering from May-Jul (Aug).

Representative Specimens: UNITED STATES. CALPORNIA: Marin Co.: $0.4 \mathrm{mi}$ SE of Horseshoe Cove, near Bodega Head, 19 Jun 1962, Bacigalupi \& Heckard 8589 (JEPS, WTU); Dillon Beach, 6 Jun 1880, Congdon s.n. (DS, MIN); Dillon Beach, 27 May 1934, Copeland s.n. (DS, MARY, POM, UC); Tomales Point, Point Reyes Peninsula, 8 Jun 1962, Hardham 10466 (CAS, RSA); Point Reyes Peninsula, W of Drakes Estero, 12 May 1941, Hoover 5069 (NY, UC, US); Abbott's Lagoon, 9 Jun 1946, J. T. Howell 21999 (CAS, COLO, DAO, DS, MO, RM, RSA, TEX, UC, UTC, WS); S of Kehoe Beach, 1 Jun 1988, Reveal 6963 (BM, BR, BRY, CAS, CLEM, G, K, KW, LE, MARY, MEXU, MO, NY, OKL, OSC, RM, RSA, SMU, US, UTC, WIS); along Sir Frances Drake Boulevard $0.6 \mathrm{mi}$ SW of ATT Overseas Receiving Station, 1 Jun 1988, Reveal 6966 (BRY, CAS, MARY, MO, OSC, RM, RSA, UTC, WIS). Sonoma Co.: Bodega Bay, Jun 1905, K. Brandegee s.n. (L, MO, NESH, PH, POM, RM, UC, US); Bodega Point, 29 Jun 1915, Eastwood 4832 (DS, GH, K, NY, UC, US); Bodega Point, 16 Jul 1956, Rose 56128 (ARIZ, B, BRY, COLO, DAO, G, GH, MIN, NY, RM, RSA, SMU, UC, US, W, WIS, WS); Bodega Point, 6 Aug 1962, Rose 62077 (CAS, COLO, DAV, DS, ENCB, G, HSC, OBI, SBBG, TEX); near Bodega Bay, 24 May 1841 , Wosnessensky 5 (LE). A total of 34 collections are known to us.

As here defined we consider the var. villosa (Latin villosus, hairy, alluding to the pubescence of the plant) to be a spreading to slightly more ascending phase of the species with slightly larger flowers and achenes, and generally straight and rather stoutish awns on the involucres. There are occasional specimens throughout the range of the variety with curved or even uncinate awns. In the majority of instances such awns are found only on a few involucres and appears to have resulted from the pressing process when herbarium specimens were prepared. Still, individuals will be found in the field with an occasionally uncinate awn, but rarely is this common and we have yet to find an individual where all of the awns are hooked although an August collection made by Hardham (s.n., MARY) comes close. Also, there are individuals at Dillon Beach in southern Marin Co. where exceptions to this might be found. Our observations indicate that the plants at Dillon Beach are typical var. villosa, but as we have not been able to examine all the plants in the area, we cannot discount the possibility that intermediates between var. villosa and var. cuspidata might exist. Finally, as the majority of the specimens of the var. villosa with uncinate awns have been collected late in the growing season, it might be that the straight awn is a retained neotonous feature.

Eastwood (1949) wrote a vivid account of her visits to Bodega Head, recounted the history of past botanical collectors to the area, and listed the twelve new species described by Fisher and Meyer collected by the Russians stationed at Fort Ross. Eastwood (1903) described four 
additional species, but all of her general collections gathered there in 1899 and in 1900 were lost in the 1906 San Francisco earthquake. We are fortunate that she was able to save the holotype and the three isotypes of Chorizanthe villosa reported above.

9. Chorizanthe robusta C. Parry, Proc. Davenport Acad. Nat. Sci. 5: 176. 1889. Chorizanthe pungens Benth. var. robusta (C. Parry) Jepson, Fl. Calif. 392. 1913.-TYPE: north of Aptos along Monterey Bay, Santa Cruz Co., California, Jun 1883, Parry s.n. (holotype: ISC!; isotypes: CAS, UC!).

Chorizanthe douglasii Benth. var. hartwegii Benth. in A. DC., Prodr. 14: 26. 1856. Chorizanthe pungens Benth. var. hartwegii (Benth. in A. DC.) Goodman, Ann. Missouri Bot. Gard. 21: 37. 1934. - TYPE: dry mountain pastures near Santa Cruz, Santa Cruz Co., California, 1847, Hartweg 1935 (holotype: K!; isotypes: BM, BR, CGE, G, GH, K, MO, OXF!).

Erect to spreading or decumbent, villous annual herbs 1-5 dm high and 1-6 dm across; leaves basal or nearly so, oblanceolate, the blades 1-3.5 (5) cm long, 2-5 (7) mm wide, villous on both surfaces, rounded apically, gradually tapering to a villous petiole $1-4(7) \mathrm{cm}$ long; inflorescences cymose with the secondary branches not suppressed except in the terminal clusters of involucres; bracts 2 , opposite, similar to the leaves only reduced at the lower nodes, $1-5 \mathrm{~cm}$ long and 2-5 (7) $\mathrm{mm}$ wide, short petiolate, becoming linear and aciculate above, acerose; involucres solitary, the tube cylindrical, 3-angled but 6-ribbed, $2.5-4 \mathrm{~mm}$ long, thinly pubescent, with a thin white to pinkish scarious margin restricted to the basal portion of the teeth, the teeth spreading, the uncinate awns of two sizes, the larger ones $0.7-1.3 \mathrm{~mm}$ long with the anterior one mostly $1-1.3 \mathrm{~mm}$ long, these alternating with the smaller ones $0.3-0.7$ $\mathrm{mm}$ long; flowers slightly exserted beyond the involucre, cylindric, $2.5-4 \mathrm{~mm}$ long, the tube white, the lobes white to rose, pubescent without along the midribs with the hairs typically extending beyond the apex, on pedicels $0.2-0.4 \mathrm{~mm}$ long, the tepals monomorphic, oblanceolate to narrowly oblong, usually truncate to rounded and erose or denticulate apically, occasionally distinctly cuspidate, united about a quarter of their length; stamens 9 , included, the filaments $2-3.5 \mathrm{~mm}$ long, glabrous, the anthers $0.6-0.8 \mathrm{~mm}$ long, oblong, pink to red or maroon; achenes light brown, 3.5-4 mm long.

Sandy to gravelly places in Alameda and San Mateo cos. (where now rare or extirpated) southward in the Coast Ranges to Santa Cruz Co. and near the coast in southern Santa Cruz and extreme northern Monterey Co., California, from 50-700 ft elev; flowering from May-Sep.

Representative Specimens: UNITED STATES. CALIFORnIA: Alameda Co.: Alameda, 4 Jul 1866, Bolander 1939 (GH, K, MO, US, WS); Alameda, May 1891, Greene s.n. (B, F, K, NDG, US); Alameda, 1888, Parny 13/2 (GH, ISC, US). Monterey Co.: Salinas Valley, Jun-Jul 1889, Abbott s.n. (CAS); 4 mi from Moss Landing on Pojano Road, 27 Sep 1903, Abrams 4047 (DS); near Soledad, Jun 1881, Congdon s.n. (DS); Del Monte, Sep 1902, Elmer 4047 (DS, GH, POM, UC); 1 mi S of San Lucas, 10 May 1935, Keck \& Stockwell 3240 (DS, UC). San Mateo Co.: Colma, Jun 1905, K. Brandegee s.n. (DS, L, NESH, RM, UC, US); Ocean View, 11 Jun 1889, Congdon s.n. (US); W of South San Francisco, 28 Jun 1913, Suksdorf 345 (GH, WS). Santa Clara Co.: Los Gatos, 1 May 1888, Leeds s.n. (F); San Jose, 1882, Parry s.n. (MO). Santa Cruz Co.: 1.5 mi E of Watsonville Junction, 19 May 1936, Belshaw 2141 (UC, USFS); 0.6 mi NW of Hazelbrook School, 26 May 1936, Belshaw 2227 (RSA, UC, USFS); Rodeo Gulch Road near Soquel, 16 Jun 1960, Hesse 2826 (CAS, DS); Sunset Beach, near Watsonville, 2 Jun 1966, Holmgren \& Reveal 2627 (ARIZ, CAS, DAO, DAV, DS, GH, IDS, ISC, K, MARY, MIN, MO, MSC, NY, RM, RSA, SMU, TEX, US, UT, UTC); Santa Cruz, 24 Apr 1881, M.E. Jones 2253 (BM, BR, CM, F, G, GH, ISC, LE, MIN, MSC, NY, PH, UTC, WU); Santa Cruz, Jun 1883, Parry s.n. (GH, ISC, K, NY, VT); Santa Cruz Mountains, 13 Jul 1882 , Pringle s.n. (F, G, LE, MIN, MPU, NY, PENN, US, VT, WU); 2 mi S of Mantesa Beach State Park, 25 Jun 1957, Raven 10978 (CAS); near Sunset State Beach, 13 Jun 1987, Reveal \& Broome 6432 (CAS, MARY, MO, NY, RSA, 
US); along Shell Road just E of Sunset Beach State Park, 13 Jun 1987, Reveal \& Broome 6433 (CAS, MARY, NY, RSA); Felton, 11 Jul 1903, B.II. Thompson s.n. (DS, MIN, SMU). A total of 64 collections are known to us.

In general Chorizanthe robusta (from the Latin robustus, hard or strong, alluding to the large size of the plant compared to related species) may be recognized by its larger involucre with a distinct, white scarious margin and flowers with variably margined tepals. The color of the involucre tends to be a brighter white or intense cream compared with the other species in the area where it occurs. The large and robust size of the individuals easily distinguishes it from $C$. diffusa while the involucres of $C$. pungens are generally smaller, more reddish, and longer awned. As noted below, the distinction between $C$. robusta and $C$. cuspidata in the eastern part of the San Francisco Bay area is much more difficult to make.

The definition of Chorizanthe robusta is still not settled with this review. The type is a coastal plant collected south of Santa Cruz. The specimens most likely came from an area just inland from the immediate coast as they are generally upright and, as the name implies, rather large and robust. Plants found on the immediate coast are generally more spreading but still decidedly robust when compared with, say, $C$. pungens. When immature and in early anthesis, the involucral margins are white, but as the plants mature, the margins can become pinkish; this is especially true of the more inland populations. On the foothills and inland in Santa Cruz Co., the plants are generally taller, essentially erect, and retain a stoutish aspect. The inland plants of Santa Cruz and Santa Clara cos. tend to be similar. The coastal expression in Monterey Co. is identical to the one found in adjacent Santa Cruz Co., but the inland forms in the Salinas Valley are puzzling. It is possible that we have misidentified robust specimens of the inland expression of $C$. pungens var. pungens as $C$. robusta. The discovery of extant populations in the Salinas Valley would certainly help resolve the difficulties we have experienced, but the likelihood of that is now remote.

To the north in Alameda Co., specimens that are here called Chorizanthe robusta may, in fact, represent an inland phase of C. cuspidata. Unlike the type from Santa Cruz Co., the tepals of the Alameda Co. plants are distinctly cuspidate rather than erose. An additional problem is to what extent does the Alameda expression represent a phase of $C$. valida. These problems will likely never be resolved. The Alameda population was last collected in 1894 .

10. Chorizanthe howellii Goodman, Ann. Missouri Bot. Gard. 21: 44. 1934.-TYPE: sand dunes on the Mendocino coastal plain, Fort Bragg, Mendocino Co., California, 26 May 1929, J. T. Howell 4233 (holotype: CAS!).

Spreading or decumbent to \pm erect, rather densely villous annual herbs $0.3-1 \mathrm{dm}$ high and 1-5 dm across; leaves basal or nearly so, spatulate to broadly obovate, the blades $1-3 \mathrm{~cm}$ long, 5-15 (18) $\mathrm{mm}$ wide, villous on both surfaces, rounded apically, gradually tapering to a villous petiole $1-4 \mathrm{~cm}$ long; inflorescences cymose with the secondary branches suppressed; bracts 2 , opposite, similar to the leaves only reduced at the lower nodes, $1-5 \mathrm{~cm}$ long and 5-15 mm wide, short petiolate, becoming linear and aciculate above, acerose; involucres solitary, the tube broadly cylindrical, 3-angled but 6-ribbed, 3-4 $\mathrm{mm}$ long, pubescent, with a conspicuous white scarious margin between the teeth and extending up the awn, the teeth spreading, the straight awns of two sizes, the larger ones $1-2 \mathrm{~mm}$ long with the anterior one mostly $2 \mathrm{~mm}$ long, these alternating with the smaller ones $0.5-1 \mathrm{~mm}$ long; flowers well exserted beyond the involucre, cylindric, (3) $3.5-4.5 \mathrm{~mm}$ long, the tube white, the lobes white to rose, pubescent without along the midribs with the hairs typically extending to the apex, on pedicels 0.2-0.4 (0.5) $\mathrm{mm}$ long, the tepals dimorphic, oblong, truncate and erose to denticulate apically, the outer tepals longer and wider than the inner ones, united about a quarter of their length; 
stamens 9 , included, the filaments 3-4 mm long, glabrous, the anthers $0.6-0.8 \mathrm{~mm}$ long, oblong, pink to red; achenes light brown, 3-4.5 mm long; $n=(36-39) 40$ (41-45) (Hardham 1989).

Sandy places in the dune areas north of Fort Bragg, Mendocino Co., California, from 20-50 $\mathrm{ft}$ elev; flowering from May-Jul.

Representative Specimens: UNITED STATES. CALIFORnIA: Mendocino Co.: N of MacKerricher State Park, 3.6 mi N of Ft. Bragg, 8 Jun 1955, Bacigalupi \& Robbins 5288 (ARIZ, CAS, JEPS, UTC); Cleone, on Ward Avenue near the ocean, 28 Jun 1978, Broome \& Cagle 2212 (CAS, MARY, OSC, RSA, UTC); Cleone, 21 May 1936, Eastwood \& Howell 2632 (CAS, F, GH, K, RSA, UC, US); Fort Bragg, 8 Jul 1938, Eastwood \& Howell 6178 (CAS, DS, F, GH, JEPS, ISC, K, MO, NY, OSC, RSA, SBBG, UC, US, WTU); Fort Bragg, 9 Jun 1962, Hardham 10464 (CAS, DAO, RSA, SBBG); Fort Bragg, 12 Jul 1931, M.E. Jones 28863 (MO, POM, UC); Fort Bragg, 1914, Mathews s.n. (JEPS). A total of 20 collections are known to us.

Chorizanthe howellii (John Thomas Howell, 1903- , noted California botanist, student of Eriogonoideae, and without embarassment, a dear friend and mentor) is a narrowly restricted endemic found in sand dune areas north of Fort Bragg along the immediate coast. The probable dominant polyploid chromosome count of $n=40$ (in spite of the range reported by Hardham in her 1989 review) seems to indicate a hybrid origin of the species, with one of the parents most likely being $C$. cuspidata var. villosa. We are uncertain what the other parent might have been, but a potential candidate is an inland population of $C$. valida with less intently colored involucres and awns. It seems probable that the isolation of the plants that today constitute $C$. howellii occurred during a period of greater regional warming. This might have occurred during the Hypsithermal of early Holocene times (ca $8000 \mathrm{bp}$ ) or during the last interglacial some $100,000 \mathrm{bp}$.

Minor variation in habit may be seen in this species. Closer to the ocean individual plants are prostrate; more inland the plants tend to be upright. This is seen in other species of the subsection as well, notably in Chorizanthe cuspidata and C. robusta.

11. Chorizanthe valida S. Wats., Proc. Amer. Acad. Arts 12: 271. 1877.-TYPE: near Fort Ross, Sonoma Co., California, 1841, Vosnesensky s.n. (holotype: GH!; isotype: LE!).

Erect to spreading, villous annual herbs 1-3 dm high and 1-6 dm across; leaves basal or nearly so, broadly oblanceolate, the blades $1-2.5$ (5) $\mathrm{cm}$ long, 4-8 (12) mm wide, villous on both surfaces but often less so to glabrate above, rounded apically, gradually tapering to a villous petiole 1-3 cm long; inflorescences cymose with the secondary branches suppressed; bracts 2 , opposite, similar to the leaves only reduced at the lower nodes, $1-3 \mathrm{~cm}$ long and 6-10 $\mathrm{mm}$ wide, short petiolate, becoming linear and aciculate above, acerose; involucres solitary, the tube cylindrical, 3-angled but 6-ribbed, 3-4 (4.5) $\mathrm{mm}$ long, finely corrugate, thinly pubescent, with a white scarious margin between the teeth, the teeth erect and red, the straight awns of two sizes, ivory- to straw-colored, the larger ones $0.7-1.3 \mathrm{~mm}$ long with the anterior one mostly $1.3 \mathrm{~mm}$ long, these alternating with the smaller ones $0.5-1$ (1.2) $\mathrm{mm}$ long; flowers well exserted beyond the involucre, cylindric, (4) $5-6 \mathrm{~mm}$ long, the tube white, the lobes white to lavender or rose, pubescent without along the lower half of the midribs, on pedicels $0.3-0.5(0.7) \mathrm{mm}$ long, the tepals dimorphic, oblong, truncate and erose to denticulate apically, sometimes individual tepals entire or rarely bilobed or even cuspidate, the outer tepals longer and wider than the inner ones, united about a quarter of their length; stamens 9 , included, the filaments $2-4.5 \mathrm{~mm}$ long, glabrous, the anthers $0.6-0.8$ (1) $\mathrm{mm}$ long, oblong, pink to red or maroon; achenes light brown, $3-4.5 \mathrm{~mm}$ long. 
Sandy places in coastal prairie on the Point Reyes Peninsula, Marin Co., and historically near Fort Ross, Sebastopol and Petaluma in Sonoma Co., California, from 50-300 ft elev; flowering from Jun-Aug.

Specimens Examined: UNITED STATES. CALIFORNIA: Marin Co.: Point Reyes, Jul 1903, Elmer 4756 (ARIZ, BKL, CAS, COLO, DS, E, G, MICH, MO, NY, ORE, POM, SMU, US, WIS, WS, Z); near Abbotts Lagoon, Point Reyes Peninsula, 10 Jun 1980, J. T. Howell et al. 53718 (B, CAS, ENCB, MO, NESH, RSA); between Abbotts Lagoon and Point Reyes Highway, 10 Jun 1980, True et al. 8472 (CAS). Sonoma Co.: Sebastopol, 12 Jul 1907 , Dows s.n. (DS); without location data, without date, Samuels 194 (GH, US); Samuels 195 (GH, US); Samuels 196 (MSC); Petaluma, without date, Unknown s.n. (ISC). Unknown Co.: without location data, without date, Samuels s.n. (GH, NY, UC).

The type of Chorizanthe valida (Latin validus, strong, apparently alluding to the plant's robust stature) was collected by the entomologist Ilya G. Vosnesensky (1816-1871), curator of the Zoological Museum in Saint Petersburg. He was in California in 1840 and 1841, collecting widely in the Russian dominated areas north of San Francisco (McKelvey 1955; Thomas 1969). Vosnesensky (or Wosnessensky) sent his plants to Saint Petersburg where unfortunately they went largely unstudied. Some were sent to Harvard where Watson examined them, but to what extent is unclear. In the 1930s Vosnesensky's collections (some 346 sheets representing 214 species and infraspecific entities) were sent to the California Academy of Sciences where J. T. Howell (1937) identified the lot. At the time, he annotated the Vosnesensky isotype as $C$. robusta.

Chorizanthe valida is an exceedingly rare species and is known today only from a single extant population on the Lunny Ranch just south of Abbott's Lagoon in the Point Reyes National Seashore. Mr. Liam Davis, park botanist, has reported to us that in 1988 he observed more than 2,000 individuals scattered over approximately 17,000 square meters. It was this population that Gordon True and Howell observed in 1980.

Historically the plant was more widespread on the Peninsula. Elmer found it in 1903 near the Point Reyes post office which was then located west of Schooner Bay and north of Creamery Bay in Drakes Estero. On the mainland, the species was found during the latter part of the last century near Petaluma and near Sebastopol. In comparing the specimens from the mainland, it appears that the Samuels collections without data are essentially identical to the sheet in the Parry collection gathered near Petaluma by an unknown collector; we suspect all are the same and all part of the same collection. The Dow specimen from Sebastopol is nearly identical to the Samuels specimens. The relationship of these specimens to the Alameda populations of Chorizanthe robusta is unclear; none of these populations are known to be extant.

The Vosnesensky collection is much more reminencent of the Elmer, True and Howell material than it is of the Dow and Samuels collections. We know that Vosnesensky collected widely in California, visiting both the Sacramento and San Francisco regions as well as exploring the country from Bodega Bay to Fort Ross to Mount St. Helena. We cannot exclude the possibility that Vosnesensky visited Point Reyes Peninsula. The association of "Fort Ross" comes from the statement in Watson (1877) that the type was collected at the "Russian Colony" and from the printed labels on the Vosnesensky specimens which state "Ross." The Leningrad isotype does have a written label but except for the collector's name and a brief descriptive phase, what might be a two-word location statement is unreadable.

Morphologically, plants of the extant population are readily distinguishable based on the highly colored involucre. The awns are bright red at the base and a bright ivory above, the contrast being markedly distinct. The more inland extirpated populations have straw-colored awns with a hint of red at the base. The erect teeth are also highly colored in contrast to the involucral tube, and with the inconspicuous but nonetheless bright white involucral border, 
the aspect of the entire structure is unique within the genus. The combination of the involucre and its exserted flower arranged in a rather tight terminal cluster make a showy display for potential pollinators and, given the observations of Liam Davis noted below, it is possible that Chorizanthe valida is commonly outcrossed.

Davis (per. comm., 1988) informed us that in the field Chorizanthe valida has a distinct floral odor and attracts several insects. Among the bees and wasps, he found the honey bee (Apis mellifera), the yellow-faced bumble bee (Bombus vosnesenski) and the solitary ground nesting wasp (Bembix americana comata) foraging on the plant. When collecting seeds he found an as yet undetermined member of Hemiptera (Lygaeidae) that closely resembles the seeds in both size and color; he speculates that there may be some coevolutionary relationship but its nature has not been determined.

This plant is clearly in need of federal protection under provisions of the Endangered Species Act of 1973, as amended, and it is our hope that immediate action will be taken to declare this species "threatened" due to habitat destruction although the only remaining site currently known appears to be well managed.

IVA(3). Chorizanthe Benth. ex R. Br. subsect. Petasata Rev. \& Hardham, subsect. nov.TYPE: Chorizanthe palmeri S. Wats.

A subsect. Uniaristatae inflorescentiis densis cum floribus exsertis et staminibus novem differt.

Plants spreading or decumbent to erect; leaves basal, oblanceolate to spatulate; bracts foliaceous and similar to the leaves only reduced at the lower nodes and often arranged as a whorl about midlength along the stem, gradually reduced above and scalelike; involucres urceolate, slightly pubescent, without a scarious margin, the teeth of two sizes, awned; flowers mostly bicolored, the tube white to yellow, the lobes white, red, rose, maroon to dark purple, exserted from the involucre, glabrous or with a few scattered hairs to sparsely pubescent without, the tepals dimorphic, the outer ones entire, truncate or obcordate to bilobed and smooth to slightly erose, mostly longer and generally broader than those of the inner whorl, the inner tepals truncate to bilobed or fimbriate, smooth or occasionally erose; stamens 9 , attached at the base of the tepals.

A taxon of five species restricted to the Coast Ranges of Monterey and Fresno cos. south to Santa Barbara Co., California, from 50-5000 ft elev, flowering May-Sep.

\section{Key to the Species}

A. Anterior involucral awn only slightly longer than the alternating longer ones, this $1-2 \mathrm{~mm}$ long, the shorter awns $0.5-1 \mathrm{~mm}$ long.

B. Flowers with rose, maroon or dark purple lobes, or if white then the involucres and branches grayish or reddish, not yellowish; inner and outer tepals not both deeply bilobed.

C. Outer tepal lobes red, maroon or dark purple, not white.

D. Outer tepals apically entire, the inner ones fimbriate, both typically erect; flowers $4-5 \mathrm{~mm}$ long; involucre slightly ventricose basally, the tube $3.5-4 \mathrm{~mm}$ long; awns $0.5-1 \mathrm{~mm}$ long, usually uncinate; on serpentine and serpentinized igneous outcrops in the Santa Lucia Mountains, the San Luis Range and the Huasna area of Monterey and San Luis Obispo cos. 12. C. palmeri

DD. Outer tepals emarginate to bilobed or erose and spreading to recurved, the inner ones shallowly bilobed or fimbriate and erect.

E. Outer tepals emarginate or deeply bilobed, the inner ones fimbriate; flowers (4.5) 5-6 $\mathrm{mm}$ long, involucres $4-6 \mathrm{~mm}$ long, slightly ventricose, with awns $0.5-1.5 \mathrm{~mm}$ long; sandy, gravelly or clay soils of Monterey and San Benito cos. south to San Luis Obispo and 
Fresno cos.

13. C. biloba

EE. Outer tepals erose or wavy, the inner ones fimbriate and slightly bilobed; flowers $4-4.5$ $\mathrm{mm}$ long; involucres $4-4.5 \mathrm{~mm}$ long, strongly ventricose, with awns $0.5-2 \mathrm{~mm}$ long; serpentine outcrops in eastern Monterey and adjacent San Benito south to eastern San Luis Obispo and adjacent Fresno cos. 14. C. ventricosa

CC. Outer tepal lobes white to pinkish, rounded to slightly obcordate, spreading, the inner ones shorter and narrower, fimbriate, erect; flowers 4-4.5 (5) $\mathrm{mm}$ long; involucres $3-4 \mathrm{~mm}$ long, slightly ventricose, with awns 0.5-1 mm long; sandy or rarely calcareous soils or siliceous shales of Monterey, San Luis Obispo and western Santa Barbara cos.

15. C. obovata

BB. Flowers white; involucres and branches yellowish-green; inner and outer tepals deeply bilobed, not fimbriate; Sierra Madre, Santa Barbara Co.

16. C. blakleyi

AA. Anterior involucral awn greatly elongated, this $1.5-2.5 \mathrm{~mm}$ long, the shorter awns $0.3-0.6 \mathrm{~mm}$ long; Monterey and San Luis Obispo cos.

17. C. rectispina

The species of the subsect. Petasata (Latin petasatus, with a hat on, alluding to the dense, colorful flat-topped inflorescences) were included by Goodman (1934) in the subsect. Uniaristatae. The distinction made here emphasizes the difference in stamen numbers, with nine in Petasata and three in Uniaristatae, although there are a number of other morphological features that augment the circumscription of each taxon. The majority of species now recognized in the Chorizanthe palmeri complex were initially described by Goodman $(1934,1939)$. Previous authors had defined C. palmeri broadly, but given the paucity of specimens, and the lack of direct field experience, this is not hard to understand. Likewise, the few specimens of $C$. rectispina that were known prior to 1934 were generally referred to $C$. uniaristata. Among the various populations of $C$. palmeri and $C$. biloba, and to a lesser extent, in $C$. obovata as well, there is considerable variation between the populations rather than within a given population. While some of the variation is distinctive, as in the case of C. biloba var. immemora, most is not consistent enough to merit taxonomic recognition.

Goodman $(1934,1939)$ was able to sort the variation into a series of species based on the morphological differences he was able to perceive in herbarium material. What he was unable to discern was the distinctive edaphic nature of each species. Munz $(1958,1959)$ initially failed to appreciate this and either reduced in rank or submerged into synonymy most of the species in this subsection. Field work in the 1960s by Hardham, coupled with the discovery of C. blakleyi (Hardham 1964), lead Munz (1968) to accept Goodman's and Hardham's concept of the taxon.

In this treatment we maintain the basic concepts expressed by Goodman $(1934,1939)$, but essentially only at the species level. His infraspecific entities are not recognized, and at least one that he (Goodman 1939) struggled unsuccessfully with is now described.

Hardham has found a scattering of individuals that appear to be of a hybrid origin involving various species of the subsect. Petasata. She found a single specimen that appears to be a hybrid between $C$. biloba and $C$. rectispina or $C$. obovata on white shale at Atascadero. Chorizanthe biloba and $C$. restispina were found to hybridize on Black Mountain following a fire. In this instance, the number of seemingly intermediate individuals was high, but now all of the plants are gone due, it would seem, to habitate modification associated with the redomination of the slopes by large shrubs.

Chorizanthe palmeri S. Wats., Proc. Amer. Acad. Arts 12: 271. 1877.-TYPE: near San Luis Obispo, San Luis Obispo Co., California, 26 Jun 1876, Palmer 464 (holotype: GH!; isotypes: B, F, G, GH, ISC, K, LE, MIN, MO, NY, PH, UC, US, VT, WU!).

Erect to spreading, appressed pubescent annual herbs (0.5) 1-3 (4) dm high and 1-3 dm 
across; leaves basal, oblanceolate, the blades $1-3 \mathrm{~cm}$ long, $4-8 \mathrm{~mm}$ wide, thinly pubescent on both surfaces, obtuse to rounded apically, gradually tapering to a pubescent petiole $1-3 \mathrm{~cm}$ long; inflorescences cymose, the involucres in dense clusters $2-4 \mathrm{~cm}$ across; bracts $2-3$ at the first node, usually foliaceous, often with a whorl of bracts about midlength along the stem, 0.5-1.5 cm long and 2-6 mm wide, elliptic, becoming reduced above, lanceolate to elliptic, 2-10 $\mathrm{mm}$ long, 1.5-5 mm wide, eventually scalelike, linear and aciculate, acerose, the straight awns 1-3 mm long; involucres urceolate and slightly ventricose basally, 3-angled but 6-ribbed, the tube 3.5-4 mm long, greenish or reddish, slightly corrugate, thinly pubescent with slender curly hairs, the teeth erect to spreading, $1-2 \mathrm{~mm}$ long, the awns mostly of the same length, 0.5-1 mm long, typically all uncinate, the longer anterior one mostly $1 \mathrm{~mm}$ long; flowers exserted beyond the involucre, cylindric, $4-5 \mathrm{~mm}$ long, the tube white to yellow, the lobes red, maroon or dark purple, glabrous or with a few scattered hairs along the midrib about midlength, on pedicels $0.2-0.3 \mathrm{~mm}$ long, the tepals dimorphic, oblong, the outer three entire and rounded apically, erect, the inner three fimbriate and truncate or somewhat bilobed, erect, those of the outer whorl slightly longer than the inner, united about half of their length; stamens 9, exserted, the filaments 4-5 mm long, glabrous, white to rose, the anthers 0.9-1 $\mathrm{mm}$ long, oblong, pink to red or maroon; achenes brown, 3-3.5 mm long; $n=19-20$ (24) (Hardham 1989).

Serpentine and serpentinized igneous outcrops mainly in the Santa Lucia Mountains, the San Luis Range and the Huasna area of Monterey and San Luis Obispo cos., California, from 200-2000 ft elev, flowering from May-Aug.

Representative Specimens: UNITED STATES. CALIFORNIA: Monterey Co.: between Willow Creek and Alder Creek, 23 Jul 1958, Hardham 3781 (CAS, SBBG); $1 \mathrm{mi} \mathrm{N}$ of Salmon Creek on California Highway 1, 30 Jun 1960, Hardham 6343 (CAS, DAO, RSA, SBBG); below Mt. Mavis, 22 Jun 1946, Hoover 6181 (CAS, OBI, OKL). San Luis Obispo Co.: ridge between San Carpoforo and Arroyo de la Cruz, 17 Jun 1960, Hardham 6170 (CAS, RSA, SBBG); Rinconada Mine between Santa Margarita and Pozo, 30 Jun 1946, Hoover 6211 (CAS, DAO, DS, OBI, OKL, UC, UTC); summit of San Luis Range above Perfumo Canyon, W of Laguna, 3 Aug 1946, Hoover 6250 (CAS, DAO, OBI, OKL, UC); lower Tar Spring Creek, 29 Jun 1948, Hoover 7552 (CAS, DAO, DS, OBI, OKL, UC); San Bernardo Creek, E of Morro Bay, 11 Jul 1964, Hoover 9190 (CAS, OBI, OKL, UC); adjacent to Cuesta Park, 24 Jun 1969, Hoover 11398 (CAS, DAV, OBI, SBBG, UC, US); N of San Simeon along the Arroyo de la Cruz, W of California Highway 1, 3 Jul 1981, Keil \& Luckow 14956 (ASU, OBI, SBBG, TEX); along Cypress Mountain Road about $0.1 \mathrm{mi}$ N of California Highway 46, 16 Jun 1987, Reveal et al. 6469 (ARIZ, CAS, MARY, MO, NY, RSA, TCD); along Cypress Mountain Road, $1 \mathrm{mi} \mathrm{N}$ of the summit from old California Highway 46, 16 Jun 1987, Reveal et al. 6470 (ARIZ, CAS, MARY, MICH, MO, NY, RM, RSA, TCD, US, WIS); Tar Spring Ridge N of Huasna Road, 5 mi E of Arroyo Grande, 18 Jun 1987, Reveal et al. 6487 (ARIZ, BM, BRY, CAS, MARY, MICH, MO, NY, RM, RSA, TCD, US, WIS); San Luis Mountain, May-Jul - , Summers s.n. (ARIZ, MO, NESH, POM, RM, UC, US). A total of 67 collections are known to us.

The concept of Chorizanthe palmeri (Edward Palmer, 1821-1911, collector and ethnobotanist in western North America) was gradually expanded with the discovery of additional populations. To a degree, the failure to recognize that some of these populations represented undescribed species was because representatives of each were few and all were found in the same part of central California. Watson (1877) knew the species only from the type, and even Parry (1884) had only a few specimens to consult. When Jepson (1913) reviewed the species, more material was available, but it was mainly Jepson who was responsible for continuing to define $C$. palmeri in broad terms.

Chorizanthe palmeri is restricted to serpentine and serpentinized igneous outcrops mainly in the Santa Lucia Mountains. The populations of Chorizanthe palmeri, and the soil types where they occur, act as geographically isolated islands and as such there has been little oportunity for populations to meet and separate again with the ebb and flow of climatic changes. For this reason, and perhaps also because of the existence of some aneuploidy, the 
populations of $C$. palmeri tend to be somewhat different one from another in morphological details. Some of these morphologically distinct and ecologically isolated populations are found at Sargent Cypress Groves near Alder Creek, Waterdog Creek, and at Little Salmon Creek, a tributary of the Nacimiento River. Most populations of the species occur on grass-free areas and, like others of the subsection, tend to flower in mass, giving the dark serpentine hillsides where they occur an unmistakable purple brillance. Most of the latter populations consist of several hundred or even thousands of individuals if the ecological setting is large enough, and tend to be more consistent and typical of the species as circumscribed by us.

\section{Chorizanthe biloba Goodman}

Erect or infrequently spreading, pubescent annual herbs (0.5) 1-3 (4) dm high and 1-3 (4) $\mathrm{dm}$ across; leaves basal, oblanceolate, the blades 1-3 (5) cm long, 4-10 (13) mm wide, thinly pubescent on both surfaces, obtuse to rounded apically, gradually tapering to a pubescent petiole $0.5-3 \mathrm{~cm}$ long; inflorescences cymose, the involucres in open clusters $2-4(6) \mathrm{cm}$ across; bracts 2-3 at the first node, usually foliaceous, often with a whorl of bracts about midlength along the stem, $0.5-1.5 \mathrm{~cm}$ long and $2-6 \mathrm{~mm}$ wide, elliptic, becoming reduced above, lanceolate to elliptic, 2-20 mm long, $1.5-8 \mathrm{~mm}$ wide, eventually scalelike, linear and aciculate, acerose, the straight awns 1-3 mm long; involucres urceolate and slightly ventricose basally, 3-angled but 6-ribbed, the tube 4-6 mm long, grayish or reddish, slightly corrugate, strigose with long hairs on the ridges, the teeth erect to spreading, 1-2 mm long, the uncinate awns mostly of the same length, $0.5-2 \mathrm{~mm}$ long, the longer anterior one straight and mostly $2 \mathrm{~mm}$ long; flowers exserted beyond the involucre, cylindric, (4.5) 5-6 mm long, the tube white to yellow, the lobes red, maroon or dark purple, sparsely pubescent along the midrib about midlength, on pedicels $0.4-0.6 \mathrm{~mm}$ long, the tepals dimorphic, obovate, the outer three bilobed or at least distinctly obcordate, spreading, the inner three fimbriate and obtuse, erect, those of the outer whorl slightly longer than the inner, united about half of their length; stamens 9, exserted, the filaments 4-5 mm long, glabrous, white to rose, the anthers $1.2-1.8 \mathrm{~mm}$ long, oblong, yellow to golden; achenes brown, 4-4.5 mm long; $n=20$ (Hardham 1989).

Sandy, gravelly or clay soils in the Coast Ranges of Monterey and San Luis Obispo cos., California, eastward to southern San Benito and western Fresno cos., from 950-2400 ft elev, flowering from May-Aug (Sep).

\section{Key to the Varieties}

A. Outer tepals deeply bilobed; Santa Lucia Mountains eastward to the western slope of the Diablo, La Panza and Temblor ranges. 13a. var. biloba AA. Outer tepals emarginate or subcordate; eastern slope of the Diablo Range. 13b. var. immemora

Chorizanthe biloba is a well marked species of non-serpentine soils. It is generally taller and more erect than $C$. palmeri and the consistently spreading, emarginate to bilobed outer tepals quickly distinguish the two. Care must be taken in the field when collecting plants of the subsect. Petasata as $C$. biloba can occur close to other species of the taxon but not always on markedly different soil types. This is particularly true in the Cottonwood Pass area where C. biloba is on the non-serpentine soils while $C$. ventricosa is on the scattered serpentine outcrops. The same distribution pattern is seen at the foot of the Parkfield Grade to the north. On the eastern foothills of the Santa Lucia Mountains, C. biloba can be found near serpentine outcrops that harbor $C$. palmeri. To a degree, individuals of $C$. biloba tend to be more scattered and less concentrated than either $C$. palmeri or $C$. ventricosa. However, in at least three locations, Black Mountain, near Atascadero and near Bee Rock, Hardham has 
found $C$. biloba growing with C. rectispina and C. obovata.

Chorizanthe biloba Goodman, Ann. Missouri Bot. Gard. 21: 73. 1934, var. biloba. Chorizanthe palmeri S. Wats. var. biloba (Goodman) Munz, Aliso 4: 89. 1958.-TYPE: Paso Robles, San Luis Obispo Co., California, 1911, K. Brandegee s.n. (holotype: MO!; isotypes: BKL, DS, NESH, POM, RM, UC, US!).

Flowers with the outer whorl of tepals deeply bilobed, occasionally erose; $n=20$ (Hardham 1989).

Sandy, gravelly or clay soils on the eastern foothills of the Santa Lucia Mountains of Monterey and San Luis Obispo cos., California, eastward to the western foothills of the Diablo, La Panza and Temblor ranges, and in extreme western Fresno Co., from 950-2225 ft elev; flowering from May-Aug.

Representative Specimens: UNITED STATES. CALIFORNIA: Fresno Co.: Waltham Creek Canyon, 12 Jun 1938 , Eastwood \& Howell 5836 (CAS, ISC, RSA, UC). Monterey Co.: Jolon, 19 Jul 1910, K Brandegee s.n. (DS, UC, US); Pleyto, 5 Jun 1960, Hardham 6033 (CAS, RSA, SBBG); along Nacimiento River at San Miguel Creek, 10 Jul 1960, Hardham 6357 (CAS, RSA); The Indians, Santa Lucia Mountains, 15 Jul 1960, Hardham 6389 (CAS, RSA); San Antonio Valley, 12 Aug 1937, Hoover 2683 (NY, UC, US); Jolon, 4 Jun 1939, Hoover 4122 (DS, K, NY, UC, US); Sulphur Springs Canyon, $2.3 \mathrm{mi}$ NE of Mission Road, 15 Jun 1987, Reveal \& Broome 6451 (ARIZ, CAS, MARY, MICH, MO, NY, RSA, TCD, US); 4.5 mi S of Parkfield on Cholame Road, 25 Jul 1963, Twisselmann 8791 (CAS); Jolon, Jun 1880, Vasey 534 (GH, PH, US). San Luis Obispo Co.: $1.2 \mathrm{mi}$ W of Creston on Templeton Road, 9 Jun 1939, Ferris 9777 (BRY, CAS, DS, GH, IDS, MICH, POM, RM, RSA, UC, UT, WTU); W of La Panza Ranch, 16 Jun 1946, Hoover 6166 (CAS, OBI, OKL, UC); W edge of Carrisa Plain at top of grade leading to San Juan River, 16 Jun 1946, Hoover 6172 (CAS, OBI, OKL); Windmill Creek, 3 Jun 1969, Hoover 11366 (CAS, OBI, UC, US); along California Highway 58, $0.4 \mathrm{mi}$ SE of Shell Creek Road, 26 May 1988, Reveal 6910 (BRY, CAS, G, MARY, MO, NY, OSC, RSA, US, UTC, WIS); along California Highway 58, 1 mi w of Shell Creek Road, 26 May 1988, Reveal 6912 (BM, BRY, CAS, MARY, MEXU, MO, NY, OSC, RSA, SMU, US, WIS); near headwater of Palo Prieta Creek, $7 \mathrm{mi}$ S of Cholame, 15 May 1952, Twisselmann 141 (CAS); Cottonwood Pass, 16 Jun 1937, Winblad s.n. (CAS). A total of 85 collections are known to us.

The var. biloba (from the Latin bi-, two, lobus, lobes, alluding to the deeply cut outer lobes of the tepals) is the common expression of the species. It occurs through the western part of the species' range and approaches the disjunct var. immemora just to the south in Fresno Co. The bilobed condition of the outer tepals is sometimes difficult to observe in dried material, but if the tepals are softened and carefully spread, the nature of the apex can be readily observed.

It is remarkable that no aneuploidy has yet been observed in the var. biloba although there is considerable morphological variability within and between some populations.

We note the existence of a Winblad collection of Chorizanthe biloba supposedly made at Balch Park in Tulare Co. We suspect the sheet is mislabelled. As an historical fact, the species was first collected by Lobb (BM!), but we have no information as to where he found it.

Chorizanthe biloba Goodman var. immemora Rev. \& Hardham, var. nov. - TYPE: near Hernandez, San Benito Co., California, 17 Aug 1933, J. T. Howell 11551 (holotype: CAS!; isotypes: DS, F, GH, K, ND, NY, OKL, RSA, UC, US, WTU!).

A var. bilobis tepalis emarginatis vel subcordatis differt.

Flowers with the outer whorl of tepals emarginate or subcordate; $n=17-23$ (Hardham 1989). 
Sandy to gravelly soils on the eastern slope of the Diablo Range in southern San Benito and adjacent Monterey cos., California, from 2000-2400 ft elev, flowering from May-Aug (Sep).

Representative Specimens: UNITED STATES. California: Monterey Co.: Priest Valley, 15 Aug 1929, Rowntree s.n. (NO, SBBG). San Benito Co.: Lorenzo Creek, 1919, Bettys s.n. (JEPS); first ridge on Hernandez Road after leaving Hollister-King City Road, 31 May 1946, Hoover 6100 (CAS, OBI); Hernandez, 7 Jun 1903, Lathrop s.n. (DS, Z); $12.9 \mathrm{mi}$ from junction N of Bitterwater on road to New Idria, 1 Sep 1955, Raven 8816 (CAS, WS); along the Clear Creek Road, 0.4 mi S of the Coalinga Road near Hernandez, 27 May 1988, Reveal \& Hardham 6928 (MARY). A total of 12 collections are known to us.

Goodman (1934) originally identified Howell 11551 as Chorizanthe biloba, but referred Lathrop s.n. (DS) to his typical expression of C. obovata. Later, Goodman (1939) renamed the Howell specimen $C$. obovata f. prostrata when he established $C$. ventricosa but failed to take into account the Lathrop specimen. Subsequent collectors have determined their specimens of var. immemora (from the Latin immemoris, unmindful, alluding to the once studied but never resolved nature of the taxon) as C. palmeri, C. biloba or C. obovata, and nearly always with uncertainty. The curious nature of var. immemora was subsequently forgotten and the plant essentially ignored until our recent collections.

Hardham believes the highly variable cytological material she observed may be indicative of past hybridization. She found meiotic chromosomes of three size classes, lots of nucleoli and atypical pollen grains. More study is required.

The plant is exceedingly local and rare. It should be considered for protection under provisions of state and federal endangered species acts.

14. Chorizanthe ventricosa Goodman, Leafl. W. Bot. 2: 193. 1939. Chorizanthe palmeri S. Wats. var. ventricosa (Goodman) Munz, Aliso 4: 89. 1958. - TYPE: Mustang Grade, between San Lucas and Priest Valley, Monterey Co., California, 11 May 1936, Eastwood \& Howell 2452 (holotype: CAS!; isotypes: F, POM!).

Spreading and diffuse, spreading pubescent annual herbs (0.5) 1-5 dm high and 1-5 (7) $\mathrm{dm}$ across; leaves basal, oblanceolate, the blades (0.5) 1-3 (4) cm long, (2) 4-10 (12) mm wide, thinly pubescent on both surfaces, obtuse to rounded apically, gradually tapering to a pubescent petiole 0.3-1 (1.5) cm long; inflorescences cymose, the involucres in rather open clusters 2-6 cm across; bracts 2-3 at the first node, usually foliaceous, often with a whorl of bracts about midlength along the stem, $0.5-1.5 \mathrm{~cm}$ long and $1-4 \mathrm{~mm}$ wide, oblanceolate to elliptic, gradually becoming reduced above, linear-lanceolate, 4-12 (15) mm long, 1.5-5 mm wide, eventually scalelike, linear and aciculate above, acerose, the straight awns 1-3 mm long; involucres urceolate and strongly ventricose basally, 3-angled but 6-ribbed, greenish or reddish, corrugate, the tube $4-4.5 \mathrm{~mm}$ long, thinly pubescent with slender curly hairs, the hairs more concentrated on the ridges, the teeth spreading, 1-3 mm long, the shorter uncinate awns mostly $0.5-1 \mathrm{~mm}$ long, the longer anterior one often straight and mostly $2 \mathrm{~mm}$ long; flowers exserted beyond the involucre, cylindric, 4-4.5 mm long, the tube white to greenishyellow, the lobes red to maroon, sparsely pubescent along the midribs about midlength, on pedicels $0.5-0.6 \mathrm{~mm}$ long, the tepals dimorphic, oblong, the outer three broadly obcordate, slightly erose or at least wavy and rounded, spreading and recurved, the inner three narrower, fimbriate and truncate or somewhat bilobed, erect, those of the outer whorl slightly longer than the inner, united about half of their length; stamens 9, exserted, the filaments $3.5-4 \mathrm{~mm}$ long, glabrous, white to rose, the anthers 1-1.3 mm long, oblong, pink to red or maroon; achenes brown, 3-3.5 mm long; $n=20-22$ (Hardham 1989). 
Serpentine outcrops in the mountain ranges of southeastern Monterey and extreme southern San Benito cos., Caiifornia, south in extreme western Fresno Co. to the Parkfield Grade area and in the Cottonwood Pass area of San Luis Obispo Co., from 1675-3200 ft elev; flowering from May-Sep.

Representative Specimens: UNITED STATES. CALIFORnIA: Fresno Co.: range S of Jacalitos Creek, 13 Jun 1938 , Eastwood \& Howell 5853 (CAS, F, GH, ISC, LA, OKL, UC); 4 mi from Parkfield junction on second upgrade, 28 May 1941, Ferris \& Bacigalupi 10362 (CAS, DS, GH, RSA, WTU); along Parkfield Grade, 4.3 mi SW of California Highway 198 and $5.5 \mathrm{mi}$ NE of the summit, 27 May 1988, Reveal \& Hardham 6930 (BM, BRY, CAS, MARY, MO, NY, OSC, RM, RSA, US, UTC, WIS). Monterey Co.: Mustang Grade, 12 Jun 1938, Eastwood \& Howell 5809 (CAS, DS, GH, MICH, POM, RSA, SBBG, UC, US); Parkfield, 13 Jun 1938, Eastwood \& Howell 5891 (CAS, GH, OSC, RSA); on the Hidden Valley Ranch walk to Serrate Sandstone Ridge, 28 May 1965, Hardham 12615 (RSA, UCSB); Mustang Grade, $2 \mathrm{mi}$ W of the summit along California Highway 198, 2 Jun 1966, Holmgren \& Reveal 2622 (ARIZ, CAS, COLO, DAO, DAV, DS, GH, IDS, ISC, K, MARY, MIN, MO, MSC, NY, PENN, RM, RSA, TEX, US, UT, UTC); along the Parkfield-Coalinga Road N of Parkfield at milepost 6.8, 19 Jun 1987, Reveal \& Broome 6488 (ARIZ, BRY, CAS, MARY, MICH, MO, NY, RM, RSA, TCD, US, WIS). San Benito Co.: Lewis Creek, 14 mi NW of Priest Valley, 11 May 1936, Eastwood \& Howell 2479 (CAS). San Luis Obispo Co.: Cottonwood Pass, E of Cholame, 8 Apr 1961, Hardham 6793 (SBBG, RSA); W side of Cottonwood Pass, 29 May 1949, Hoover 7730 (CAS, DS, OBI, OKL, RSA, UC); $0.5 \mathrm{mi}$ SW of Yellow Mountain, 14 May 1937, Peterson 837 (RSA, UC). A total of 37 collections are known to us.

Chorizanthe ventricosa (from the Latin ventricosus, potbellied, bulging, alluding to the swollen base of the involucral tube) is most readily distinguished by its pronounced, basally ventricose involucral tube and by its narrow, usually erose, obcordate, spreading outer tepals paired with the shorter, fimbriate, erect inner tepals. Specimens of this species were unknown to Goodman prior to 1934 when he published his monograph on Chorizanthe so when Eastwood and Howell discovered the plant, its distinctiveness was noted immediately by Howell.

The species is closely related to Chorizanthe palmeri, and like that entity, is found only on serpentine outcrops where it often occurs in large numbers in dense patches. It is found to the east of $C$. palmeri and nowhere do the two overlap geographically.

15. Chorizanthe obovata Goodman, Ann. Missouri Bot. Gard. 21: 70. 1934.-TYPE: Price Canyon, San Luis Obispo Co., California, 1911, K. Brandegee 84 (holotype: MO!; isotypes: ARIZ, B, BKL, BM, CAN, E, F, G, GH, K, LE, NESH, NMC, ORE, POM, RM, UC, US!).

Chorizanthe obovata Goodman f. prostrata Goodman, Ann. Missouri Bot. Gard. 21: 71. 1934. - TYPE: hills near San Luis Obispo, San Luis Obispo Co., California, Jun 1878, Lemmon s.n. (holotype: MO!; isotypes: CM, F, PH!).

Erect to prostrate, spreading pubescent annual herbs (0.5) 1-3 (4) dm high and 1-4 (5) $\mathrm{dm}$ across; leaves basal, oblanceolate, the blades $0.5-2.5 \mathrm{~cm}$ long, 3-10 mm wide, thinly pubescent on the upper surface, soft-hirsute below, acute to rounded apically, gradually tapering to a pubescent petiole $0.5-2$ (3) $\mathrm{cm}$ long; inflorescences cymose, the involucres in open clusters 2-4 (6) $\mathrm{cm}$ across; bracts 2-3 at the first node, usually foliaceous, without a whorl of bracts about midlength along the stem, $0.5-1.5 \mathrm{~cm}$ long and $2-6(8) \mathrm{mm}$ wide, elliptic, abruptly reduced above and typically scalelike, linear, 2-10 mm long, 1-3 mm wide, aciculate and acerose, the straight awns 1-2 mm long; involucres urceolate and slightly ventricose basally, 3-angled but 6-ribbed, grayish, slightly corrugate, the tube 3-4 mm long, thinly to densely pubescent with curly hairs, the hairs longer on the ridges, the teeth erect to spreading, 1-2 $\mathrm{mm}$ long, the shorter uncinate awns mostly of the same length, $0.5-1 \mathrm{~mm}$ long, the longer anterior one straight and mostly $1 \mathrm{~mm}$ long; flowers exserted beyond the involucre, cylindric, 4-4.5 (5) $\mathrm{mm}$ long, the tube greenish-white to white, the lobes white or sometimes becoming 
tinged with pink at maturity, sparsely pubescent along the midribs about midlength, on pedicels $0.3-0.4 \mathrm{~mm}$ long, the tepals dimorphic, obovate, the outer three rounded or slightly obcordate, spreading, the inner three fimbriate and narrower, erect, those of the outer whorl about twice as long as the inner, united about half of their length; stamens (6) 9, mostly included, the filaments 4-4.5 mm long, glabrous, white, the anthers 0.9-1.1 mm long, oblong, yellow to golden; achenes brown, 3-3.5 mm long; $n=19-21$ (Hardham 1989).

Sandy or rarely calcareous soils in the Coast Ranges of Monterey and San Luis Obispo cos. south to Santa Barbara Co., California, from 50-4000 ft elev; flowering from May-Jul

Representative Specimens: UNITED STATES. CALIFORNIA: Monterey Co.: Bryson, 3 Jul 1963, Hardham 10922 (RSA, SBBG, UCSB). San Luis Obispo Co.: Atascadero, on Santa Barbara Road, 10 Jun 1959, Hardham 4881 (CAS, DAO, UC); upper Cuyama Valley, 8 Jul 1930, Hoffmann s.n. (JEPS, SBBG); 5 mi SE of Santa Margarita on road to Pozo, 2 Jun 1946, Hoover 6112 (CAS, DAO, DS, OBI, OKL, OSC); 6 mi S of San Luis Obispo, 13 Jun 1946, Hoover 6142 (CAS, DAO, DS, OBI, OKL, OSC, SD, UC); $4 \mathrm{mi}$ W of Nipomo, 10 Jul 1947, Hoover 7287 (CAS, DAO, OBI, RSA); Price Canyon, 3 mi N of Pismo Beach, 20 Jun 1987, Reveal \& Broome 6498 (ARIZ, CAS, MARY, MICH, MO, NY, RM, RSA, US, WIS); W of Indian Knob and N of Squire Canyon, 6 air mi NW of Grover City, 18 Jun 1987, Reveal et al. 6482 (ARIZ, BM, BRY, CAS, MARY, MICH, MO, NY, RM, RSA, TCD, US, WIS); along Summit Station Road, Nipomo Mesa, NW of Nipomo, 20 Jul 1973, Tilforth \& Dourley 956 (MICH, RSA). Santa Barbara Co.: 1.1 mi SW of mouth of Davy Brown Canyon, 2 Jun 1935, Axelrod 535 (RSA, UC); 0.4 mi E of junction of Old Miranda Pine Road and Smith Canyon Road, Sierra Madre Mountains, 3 Jun 1963, E.R. Blakley 5973 (RSA, SBBG); between Point Sal and Lions Head, Vandenberg Air Force Base, 22 Jul 1973, E.R. Blakley 7170 (SBBG); along Figueroa Mountain Road, 16 Jul 1965, Chandler 2595 (MICH, SBBG); near Mono Flat Ranger Station, 3 Jul 1923, A.L. Grant 1685 (JEPS, MO); E end of Hurricane Deck, San Rafael Mountains, 24 May 1962, Hardham 10460 (CAS, RSA, SBBG); San Marcos Pass, 16 Aug 1927, Hoffmann s.n. (JEPS, POM, SBBG); 4.5 mi NNW of Los Alamos, 18 May 1935, Lee 376 (RSA, UC); Mono Flat, 0.5 mi W of Camuesa, 7 Jun 1946, Mason 12822 (JEPS, OKL, UC); Figueroa Mountain Road S of Grass Mountain, San Rafael Mountains, 5 Jun 1954, Sharsmith 4418 (ARIZ, B, BM, BR, BRY, CAN, DAO, ID, IDS, ILL, LL, MIN, NY, OKL, RM, RSA, SMU, UC, US, UTC, WIS, WS). A total of 93 collections are known to us.

The distinctiveness of Chorizanthe obovata (from the Latin ob-, toward or to, and ovatus, egg-shaped, alluding to the shape of the outer tepals), once it was isolated by Goodman (1934), has not been challenged. Specimens gathered prior to 1934 were assigned a variety of names, but most were referred to $C$. palmeri or less often $C$. staticoides. The white flowers quickly distinguish this species from the remainder of those species of the $C$. palmeri complex having rather dense inflorescences. The spreading, obovate, outer tepals also distinguish the species. For the most part the plant grows on non-serpentine soils where it is often found in great numbers and over large areas. From a distance, the plants in full flower are rather spectacular against the straw-colored background so common on the hills where it grows.

The distribution of the species may be divided into two units, a northern one mainly in San Luis Obispo Co., and a second in the Santa Ynez and Sierra Madre mountains of Santa Barbara Co. The more southern plants have a slightly more robust aspect compared with the typical phase and are more likely to become pink when mature, but no distinction is proposed.

Hardham found an individual near See Canyon in southern San Luis Obispo Co. with only six stamens.

16. Chorizanthe blakleyi Hardham, Leafl. W. Bot. 10: 95. 1964. - TYPE: $1 \mathrm{mi}$ E of McPherson Peak, S of Hog Pen Spring, between the heads of Aliso Canyon and Mine Canyon, Sierra Madre Mountains, Santa Barbara Co., California, 29 Jun 1963, Blakley 6076 (holotype: CAS!; isotypes: B, GH, K, NY, RSA, SBBG!). 
Spreading to ascending, spreading pubescent annual herbs 0.5-1.5 dm high and 0.5-3 dm across; leaves basal, oblanceolate, the blades $0.5-2.5 \mathrm{~cm}$ long, $3-8 \mathrm{~mm}$ wide, thinly pubescent on both surfaces, acute to rounded apically, gradually tapering to a pubescent petiole $0.5-2$ $\mathrm{cm}$ long; inflorescences cymose, yellowish-green, the involucres in rather dense clusters 1-2 $\mathrm{cm}$ across; bracts 2, opposite, usually foliaceous, without a whorl of bracts about midlength along the stem, $0.5-1.5 \mathrm{~cm}$ long and $1.5-3 \mathrm{~mm}$ wide, oblanceolate, gradually reduced above and typically scalelike, linear, 3-8 $\mathrm{mm}$ long, $1-2 \mathrm{~mm}$ wide, aciculate and acerose, the straight awns 1-2.5 mm long; involucres urceolate and slightly ventricose basally, 3-angled but 6ribbed, yellowish-green, slightly corrugate, the tube 3-4.5 mm long, thinly pubescent with slightly appressed hairs, the hairs longer and more dense on the ridges, the teeth spreading, 1-3 mm long, the shorter uncinate awns mostly of the same length, $0.5-1.5 \mathrm{~mm}$ long, the longer anterior awn straight or slightly curved and mostly $2 \mathrm{~mm}$ long; flowers exserted beyond the involucre, cylindric, 5-6 mm long, the tube greenish-white to white, the lobes white, sometimes becoming pinkish at maturity, sparsely pubescent along the midribs about midlength, on pedicels $0.2-0.3 \mathrm{~mm}$ long, the tepals dimorphic, obovate, the outer three bilobed, erect, the inner three bilobed and erose, erect, the outer whorl slightly longer than the inner, united about two-thirds of their length; stamens 9, included, the filaments 5-5.5 mm long, glabrous, white, the anthers 1-1.2 mm long, oblong, yellow to golden; achenes brown, 3-3.5 mm long; $n=$ ca 19 (Hardham 1989).

Sandy or gravelly soil on the northern slopes and foothills of the Sierra Madre Mountains, Santa Barbara Co., California, from 2000-5000 ft elev; flowering from May-Jul.

Specimens Examined: UNITED STATES. CALIFORNIA: Santa Barbara Co.: near gate to the White Oak Ranch, Bates Canyon, 29 May 1964, Chandler 1863 (OKL, SBBG); near White Oak Guard Station in Bates Canyon, 29 May 1964, Chandler 1875 (SBBG); Schoolhouse Canyon, 29 May 1964, Chandler 1916 (GH, OKL, RSA, SBBG, UCSB); N of White Oak Guard Station in Bates Canyon, 18 May 1965, Chandler 2304 (SBBG); Bates Canyon Road, 1 mi N of White Oak Ranch Gate, 18 May 1965, Chandler 2313 (RSA, SBBG); mesa between Bates Canyon and Schoolhouse Canyon, 18 May 1965, Chandler 2322 (SBBG, US); lower Schoolhouse Canyon, 18 May 1965 , Chandler 2328 (SBBG, RSA, US); Aliso Canyon Road, W of Bitter Creek, Sierra Madre Mountains, 3 Jun 1965, Chandler 2392 (MICH, RSA, SBBG); White Oak Ranch area, Bates Canyon, 12 Jun 1968, Chandler 3802 (RSA); ridge top $1 \mathrm{mi} \mathrm{SE}$ of McPherson Peak, 29 Jun 1977, Fairfax s.n. (UCSB, USFS); W of Branch Canyon, 24 May 1988, Reveal 6880 (BM, BRY, CAS, G, MARY, MO, NY, OSC, RM, RSA, US, UTC, WIS); 1 mi NE of Aliso Park on a ridge E of Aliso Canyon, 22 Jun 1987, Reveal \& Broome 6522 (MARY); below White Oaks Guard Station in Bates Canyon, 4 Jun 1964, Smith 8452 (CAS).

This narrowly endemic species is found mainly in the pinyon-juniper woodlands on the foothills on the northern side of the Sierra Madre Mountains. The type was collected on the summit of the range where it is infrequent; what populations might exist between the foothills and crest are still unknown. Detailed field work in the area should be undertaken to ascertain the full distribution of Chorizanthe blakleyi (Elwood Robert "Jim" Blakley, 1924- , long-time collector associated with the Santa Barbara Botanical Garden). This is one of those species that might be a potential candidate for protection under provisions of state and federal endangered species legislation. We have cited all of the specimens we have examined to assist in this effort.

The bright yellowish-green branches and involucres quickly distinguishes Chorizanthe blakleyi from the remaining species in the subsect. Petasata. The white flowers ally this species with $C$. obovata but the two do not overlap geographically. 
17. Chorizanthe rectispina Goodman, Ann. Missouri Bot. Gard. 21: 72. 1934. - TYPE: McGinness, $25 \mathrm{mi}$ NE of San Luis Obispo, San Luis Obispo Co., California, 10 Jul 1876, Palmer 466 (holotype: MO!; isotypes: B, CAS, F, G, GH, ISC, LE, MIN, NY, PH, US, WU!).

Spreading to decumbent, appressed pubescent annual herbs 0.3-0.8 (1) dm high and 0.5-4 (5) $\mathrm{dm}$ across; leaves basal, oblanceolate to spatulate, the blades 0.5-1.5 (2) cm long, 2-6 mm wide, thinly pubescent on both surfaces, acute to rounded apically, gradually tapering to a pubescent petiole $0.5-2 \mathrm{~cm}$ long; inflorescences cymose, the involucres in open and scattered clusters $0.5-1.5 \mathrm{~cm}$ across; bracts 2, opposite, usually foliaceous, without a whorl of bracts about midlength along the stem, $0.5-1.5 \mathrm{~cm}$ long and $1.5-5 \mathrm{~mm}$ wide, oblanceolate to elliptic, gradually reduced above and scalelike, linear, 3-8 $\mathrm{mm}$ long, 1-2 $\mathrm{mm}$ wide, aciculate and acerose, the straight awns $0.5-1.5 \mathrm{~mm}$ long; involucres urceolate and slightly ventricose basally, 3-angled but 6-ribbed, grayish to reddish, slightly corrugate, the tube 2-2.5 (3) $\mathrm{mm}$ long, densely pubescent with appressed hairs, the hairs longer on the ridges, the teeth spreading, the shorter five 0.3-0.6 mm long with uncinate awns 0.3-0.5 mm long, the greatly elongated anterior tooth erect to slightly divergent, $2-3 \mathrm{~mm}$ long, the straight awn $1.5-2.5 \mathrm{~mm}$ long; flowers exserted beyond the involucre, cylindric, $3.5-4 \mathrm{~mm}$ long, the tube yellow, the lobes yellow or white, sparsely pubescent along the midribs about midlength, on pedicels $0.4-0.6$ $\mathrm{mm}$ long, the tepals dimorphic, obovate, the outer white lobes obovate to nearly orbicular, truncate to slightly bilobed, spreading, the inner yellow lobes broadly obovate, truncate and erose, erect, those of the outer whorl 3-4 times longer than those of the inner whorl, united about half of their length; stamens 9 , included, the filaments $1-1.5 \mathrm{~mm}$ long, glabrous, white, the anthers 0.5-0.6 mm long, oblong, yellow to golden; achenes brown, 3-3.5 mm long; $n=$ (18) 20 (22) (Hardham 1989).

Sandy to gravelly soils in the Coast Ranges of southern Monterey and northern San Luis Obispo cos., California, from $700-1700 \mathrm{ft}$ elev, flowering from May-Jul.

Representative Specimens: UNTTED STATES. CALIFORNIA: Monterey Co.: W side of Hames Valley, JolonBradley Road, 8 Jun 1961, Hardham 7298 (B, BM, CAS, COLO, DAO, E, ENCB, G, RSA, SBBG, SD, W); W side of Hames Valley, Jolon-Bradley Road, 27 Jun 1962, Hardham 10343 (ARIZ, B, BM, CAS, DAO, DAV, E, G, GH, ISC, MICH, MIN, MO, NO, RM, RSA, SBBG, SD, UC, UTC, W, WS); along Cross Road 2.5 mi NE of the Jolon Road, 19 Jun 1987, Reveal \& Broome 6497 (CAS, MARY, MICH, MO, NY, RSA, TCD, WIS); Pine Canyon, 2.5 mi NE of Lockwood, 27 May 1988, Reveal \& Hardham 6922 (BM, BRY, CAS, MARY, MO, OSC, RSA, WIS). San Luis Obispo Co.: Rocky Canyon, E of Atascadero, 6 Jun 1960, Buttenworth s.n. (SBBG, RSA); $7.5 \mathrm{mi}$ E of Santa Margarita on North Circuit Road, Park Hill District, 25 May 1955, Ferris 12833 (DS, RSA, UC); Black Mountain, 22 Jun 1957, Hardham 2279 (CAS, RSA); Atascadero on Santa Barbara Road, 19 Jun 1959, Hardham 4843 (CAS, DAO, ENCB, RSA, UC). A total of 24 collections are known to us.

As Goodman (1934) noted, Chorizanthe rectispina (from the Latin rectus, straight, and spina, spine, alluding to the long, straight anterior involucral awn) was long confused with C. uniaristata, but the two are well differentiated and not all that closely related as expressed in our removal of it and its relatives to a new subsection. In the field, $C$. rectispina is a spreading to decumbent plant with an open aspect. Unlike the remaining members of the subsect. Petasata, individuals of $C$. rectispina are never numerous so that the plants are never obvious from a distance. Individually, however, the brightly bicolored flowers are spectacular, and the long, sharp, anterior awn-along with the other awns on the involucre-can make the collecting of this species a painful experience.

The McGuiness Ranch was probably at the head of Rocky Canyon southeast of Atascadero along an old road between Creston and San Luis Obispo that was used to haul wheat. 
IVA(4). Chorizanthe Benth. ex R. Br. subsect. Uniaristatae Goodman, Ann. Missouri Bot. Gard. 21: 70. 1934.- TYPE: Chorizanthe uniaristata Torr. \& A. Gray, according to Art. 22.4 of the ICBN.

Plants spreading to ascending; leaves basal, oblanceolate; bracts foliaceous and similar to the leaves only reduced at the lower nodes, gradually reduced above and scalelike; involucres urceolate, slightly pubescent, without a scarious margin, the teeth of two sizes, awned; flowers white, included to slightly exserted from the involucre, sparsely pubescent without, the tepals monomorphic, linear-oblong, the outer lobes rounded with a minute cusp or 3 tceth or entire to emarginate or slightly bilobed, the inner lobes acute, entire to erose or even bilobed to fimbriate; stamens 3, attached at the base of the tepals.

A bispecific taxon in the Coast Ranges of Mendocino and Lake cos. south to the Transverse Ranges and Tehachapi Mountains of Kern and Santa Barbara cos., into the southern Sierra Nevada in Tulare Co., California, from 200-6650 ft elev, flowering (Apr) May-Aug (Sep).

\section{Key to the Species}

A. Anterior involucral awn uncinate; involucral tube $3-3.5 \mathrm{~mm}$ long; outer tepals entire or emarginate to slightly bilobed; inner tepals entire to erose or bilobed to slightly fimbriate. 18. C. clevelandii

AA. Anterior involucral awn straight; involucral tube 2-3 mm long; outer tepals cuspidate or 3-toothed; inner tepals entire.

19. C. uniaristata

As here defined, the subsect. Uniaristatae (from the Latin uni-, one, and aristatus, with awns, alluding to the one exceeding long anterior awn compared with the remaining five shorter ones) is restricted to those phylogenetically advanced species with three stamens. We have placed those species with nine stamens that Goodman (1934) referred to Unaristatae in a new subsection, Petasata.

18. Chorizanthe clevelandii C. Parry, Proc. Davenport Acad. Nat. Sci. 4: 62. 1884. - LeCTOTYPE: Allen [actually Houghs] Springs, Lake Co., California, Jun 1882, Cleveland s.n. (lectotype: ISC!, selected by Goodman, Ann. Missouri Bot. Gard. 21: 76. 1934; duplicates of the lectotype: GH, MO, NY, SD!).

Spreading to decumbent, appressed pubescent annual herbs 0.2-0.8 (1) dm high and 0.5-5 (7) $\mathrm{dm}$ across; leaves basal, oblanceolate, the blades 0.5-1.5 (2) $\mathrm{cm}$ long, 3-6 (8) $\mathrm{mm}$ wide, thinly pubescent on both surfaces but somewhat more densely so below than above, acute to rounded apically, gradually tapering to a pubescent petiole $0.5-2 \mathrm{~cm}$ long; inflorescences cymose, the involucres in small clusters $0.5-1.5 \mathrm{~cm}$ across; bracts 2 , opposite, usually foliaceous, the blades $0.5-1.5 \mathrm{~cm}$ long, $1.5-5 \mathrm{~mm}$ wide, oblanceolate to elliptic, gradually reduced above and typically scalelike, linear, 4-10 mm long, 1-2 (3) $\mathrm{mm}$ wide, aciculate and acerose, the straight awns 1-3 mm long; involucres urceolate and slightly ventricose basally, 3-angled but 6-ribbed, grayish to reddish, slightly corrugate, the tube 3-3.5 $\mathrm{mm}$ long, densely grayish pubescent with spreading hairs, the hairs longer on the ridges, the five smaller teeth widely spreading, $0.3-0.6 \mathrm{~mm}$ long with uncinate awns $0.3-0.5 \mathrm{~mm}$ long, the greatly elongated anterior tooth erect to slightly divergent, 3-6 mm long, the uncinate awn $2.5-4.5 \mathrm{~mm}$ long; flowers included or only slightly exserted beyond the involucre, cylindric, $2.5-3 \mathrm{~mm}$ long, the tube greenish-white, the lobes white, sparsely pubescent without along the midribs with the hairs not exceeding the tepals, on pedicels $0.3-0.5 \mathrm{~mm}$ long, the tepals linear-oblong, the 
outer lobes rounded, entire or emarginate to slightly bilobed, the inner lobes acute, entire to erose, slightly fimbriate or bilobed, about a third shorter than those of the outer whorl, united about two-thirds of their length; stamens 3, included, the filaments $2-2.5 \mathrm{~mm}$ long, glabrous, white, the anthers 0.3-0.4 mm long, oval, white; achenes brown, $2.5-3 \mathrm{~mm}$ long; $n=$ 21 (Hardham 1989).

Sandy to gravelly soils in the Coast Ranges from Mendocino and Lake cos. south to Santa Barbara Co., hence across the Transverse Ranges and the Tehachapi Mountains of Ventura and Kern cos. to the southern Sierra Nevada in Tulare Co., California, from 1400-6650 ft elev; flowering from (May) Jun-Aug (Sep).

Representative Specimens: UNITED STATES. CALIFORNIA: Kern Co.: S side of Black Mountain, Greenhorn Range, 9 Jul 1962, J. T. Howell 38371 (CAS, DAV, NY, RENO). Lake Co.: without location data, Jun 1886, $K$. Brandegee s.n. (ARIZ, NESH, PH, POM, RM); edges of springs on the N edge of the Binkley Ranch, Glenbrook Road, $1.3 \mathrm{mi}$ SW of the junction of Bottle Rock Road and $3 \mathrm{mi}$ W of the junction with California Highway 175 , 26 Jun 1978, Broome \& Cagle 2205 (CAS, MARY, MO, OSC, RSA); E side of lower end of Clear Lake, 9 Jun 1938, Hoover 3562 (DS, K, NY, UC, US, UTC, WS); Bartlett Flat, 21 Jun 1945, J. T. Howell 21198 (CAS, F, MIN); near Uncle Sam Mountain, Jul 1892, Jepson s.n. (JEPS, MIN, NY, UC); between Cobb Mountain and Adams Springs on the Binkley Ranch, 25 Jun 1933, Jussel 143 (CAS, GH, K, OKL, RSA, UC). Mendocino Co.: Rice Fork of the Eel River near the confluence with Bear Creek, 5 Jul 1928, M.O. Baker 3097b (CAS). Monterey Co.: Hanging Valley, $10.4 \mathrm{mi}$ SW of Arroyo Seco, 7 Jul 1962, Breedlove 3803 (CAS, UCSB); Tassajara Hot Springs, Jun 1901, Elmer 3245 (B, G, K, MIN, MO, ORE, POM, US, VT, Z); Jolon, Jun 1915, H.M. Hall 10033 (E, GH, UC, US); between Los Bueyes Creek and the Nacimiento River, 29 May 1960, Hardham 5920 (BRY, CAS, DAO, SBBG); head of Mission Creek, Santa Lucia Mountains, 8 Jul 1955, J. T. Howell 30572 (CAS, OKL, RSA, US). San Benito Co.: near Hernandez, 17 Aug 1933, Eastwood \& Howell 11552 (CAS, F, GH, K, OKL, UC). San Luis Obispo Co.: Franklin Creek, W of Adelaida, 26 May 1961, Hardham 7136 (B, CAS, W). Santa Barbara Co.: saddle between East and West Big Pine Mountain, San Rafael Mountains, 29 Jun 1961, E.R. Blakley 4513 (CAS, JEPS, RSA, SBBG). Santa Clara Co.: Santa Isabella Creek, E base of Mt. Hamilton, 21 May 1934, Sharsmith 1132 (DS, UC, WS). Sonoma Co.: Petrified Forest, 31 Aug 1888, Greene s.n. (NDG). Tulare Co.: 1.5 mi E of Johnsondale, 22 May 1962, J. T. Howell 37366 (CAS). A total of 89 collections are known to us.

When Parry (1884) proposed Chorizanthe clevelandii (Daniel Cleveland, 1838-1929, amateur naturalist and plant collector, long-time resident of San Diego) he cited several specimens, giving the location data for the lectotype selected by Goodman (1934) as having been collected at Allen Springs. An examination of Cleveland's specimens, and the correspondence between Parry and Cleveland, it is clear that the type was gathered at Houghs Springs, four miles east of Allen Springs. Cleveland traveled to Allen Springs for his health, exploring the nearby areas for unusual plants. Cleveland first found the species in 1881, sending a specimen to Parry in a letter dated 23 January 1882. Encouraged to collect more material, Cleveland did so, visiting Houghs Springs in June of the following year. His specimens were immediately sent to Parry with a letter postmarked Allen Springs. Assuming that Cleveland collected the new species here, Parry distributed duplicates of the type with this information on the label; he also published the same information when he proposed the species. When Cleveland prepared his own specimens, he gave the correct collection site and sent a duplicate to the Missouri Botanical Garden. There may be additional duplicates of the type that we have been unable to recognize, but given that Cleveland collected the species twice, it may be impossible to unequivocally determine all of the isotypes.

Chorizanthe clevelandii is the most widely distributed species of the genus endemic to California. The involucres readily adhere to clothing and fingers, and most likely to animal fur as well, thereby accounting for its broad distribution. The plant is found among grasses mainly in the oak woodlands and we propose that grazing animals have been largely responsible for its widespread distribution. 
19. Chorizanthe uniaristata Torr. \& A. Gray, Proc. Amer. Acad. Arts 8: 195. 1870.- TYPE: New Idria, San Benito Co., California, Jul 1861, Brewer 2739 (holotype: GH!; isotypes: UC, US!).

Spreading or ascending, mostly appressed pubescent annual herbs 0.2-0.6 (0.8) dm high and 0.5-4 (5) dm across; leaves basal, oblanceolate, the blades 0.5-1.5 (2) cm long, 2-8 mm wide, thinly pubescent on both surfaces but somewhat more densely so below than above, acute to rounded apically, gradually tapering to a pubescent petiole $0.5-2 \mathrm{~cm}$ long; inflorescences cymose, the involucres in small open clusters, $0.5-1.5 \mathrm{~cm}$ across; bracts 2 , opposite, usually foliaceous, the blades $0.5-1.5 \mathrm{~cm}$ long, $1.5-5 \mathrm{~mm}$ wide, oblanceolate to elliptic, gradually reduced above and typically scalelike, linear, 4-12 mm long, 1-2 (3) mm wide, aciculate and acerose, the straight awns $1.5-4 \mathrm{~mm}$ long; involucres urceolate and slightly ventricose basally, 3-angled but 6-ribbed, grayish to reddish, slightly corrugate, the tube 2-3 mm long, densely grayish pubescent with slightly appressed hairs, the hairs longer on the ridges, the five smaller teeth widely spreading, 0.3-0.6 mm long with uncinate awns 0.3-0.5 mm long, the greatly elongated anterior tooth erect to slightly divergent, 3-6 mm long, the straight awn 2.5-5.5 mm long; flowers included or only slightly exserted beyond the involucre, cylindric, 2-3 mm long, the tube greenish-white, the lobes white, sparsely pubescent without along the midribs with the hairs not exceeding the tepals, on pedicels $0.1-0.3 \mathrm{~mm}$ long, the tepals linearoblong, the outer lobes rounded but with a minute cusp or 3 teeth, the inner lobes acute, entire, just slightly shorter than those of the outer whorl, united about two-thirds of their length; stamens 3 , included, the filaments $1-2 \mathrm{~mm}$ long, glabrous, white, the anthers 0.4-0.5 mm long, oval, white; achenes brown, 2-3 mm long; $n=$ (39) 40 (41) (Hardham 1989).

Sandy to gravelly, talus or clay soils in the inner Coast Ranges of Contra Costa, Monterey, San Benito and Fresno cos. south through western Kern and San Luis Obispo cos., California, south to Santa Barbara Co. hence across the Transverse and Tehachapi ranges of southern Kern Co. to the southern Sierra Nevada in Tulare Co., from 2700-6150 ft elev, flowering from (Apr) May-Jul.

Representative Specimens: UNITED STATES. CALIFORnIA: Contra Costa Co.: Mt. Diablo, Jun 1884, Curran s.n. (F, GH, LE). Fresno Co.: Los Gatos Creek Road W of Coalinga, 29 May 1965, Hardham 12599 (RSA); Raisin City, 27 May 1937, Hoover 2322 (DS, NY, UC, US). Kern Co.: Walker Basin, 24 Jun 1891, Coville \& Funston 1090 (DS, K, NY, US); E of Bakersfield on road to Tehachapi, 12 Jun 1921, Ferris \& Duncan 2205 (CAS, DS, NY); "Skunk Well Canyon" near Mariannas Ranch, Temblor Range, 17 May 1953, Hoover 8315 (CAS, ILL, OBI, OKL, RM, UC, UTC, WIS, WS, WTU); 5 mi E of Bakersfield, 20 May 1962, J. T. Howell 37097 (CAS, DAV, NY, RENO); summit above Drake Ridge, Temblor Range, 25 Jun 1963, Twisselmann 8484 (CAS, RSA, SBBG). Kings Co.: junction of highways 41 and 33, 29 Apr 1949, Solheim \& Solheim 2511 (OKL). Monterey Co.: 3.7 mi N of San Antonio School, 12 May 1959, Hardham 4485 (CAS, SBBG); Lockwood-San Lucus Road, 3 Jun 1962, Hardham 10300 (CAS, DAO, RSA, SBBG); near Gonzales, Jul 1891, Norton s.n. (CAS, DS); above Jolon, Santa Lucia Mountains, 25 Jun 1945, Ripley \& Barneby 6967 (CAS, NY). San Benito Co.: along California Highway 25, 0.4 mi $\mathrm{N}$ of the Coalinga Road and 8.4 mi S of San Benito, 27 May 1988, Reveal \& Hardham 6926 (CAS, MARY, RSA). San Luis Obispo Co.: base of Caliente Mountain, Bill Washburn Ranch, 20 Jul 1957, Hardham. 2471 (CAS, DAO, RSA, SBBG); hills between San Juan Creek and Carrisa Plains, 13 May 1960, Hardham 5682 (CAS, RSA, SBBG, UC); Freeborne Mountain, 20 Jun 1963, Hardham 10839 (RSA, UCSB); along California Highway 58, 0.6 mi E of San Juan Creek between La Panza and Carrisa Plains, 26 May 1988, Reveal 6906 (CAS, MARY, MO, RSA). Santa Barbara Co.: below White Oaks Guard Station, Bates Canyon, 4 Jun 1964, C.N. Smith 8453 (CAS, GH, RSA, SBBG, W, SD). Santa Clara Co.: W side of the divide between Arroyo del Puerto and San Antonio Valley, Red Mountains, 25 May 1936, Sharsmith 3794 (DS, UC). Tulare Co.: Pixley Natural Area, 5 mi E of Pixley, May 1963, Zaninovich s.n. (CAS). Ventura Co.: above Camp Ozena, 2 Jun 1967, Chandler 3501 (RSA, SBBG); Tinto Creek, upper Cuyama River Valley, 11 Jun 1965, Hardham 12746 (UCSB). A total 86 collections are known to us. 
Chorizanthe uniaristata (from the Latin uni-, one, and aristatus, with awns, alluding to the one exceeding long anterior awn compared with the remaining five shorter ones) is the only polyploid among the species belonging to the subsections Petasata and Uniaristatae and appears to represent the terminal expression within the complex. It also has the smallest meiotic chromosomes observed by Hardham. We are uncertain as to its origin, but it is tempting to hypothesize an autoallopolyploidy origin involving $C$. clevelandii and $C$. rectispina.

IVA(5). Chorizanthe Benth. ex R. Br. subsect. Parryanae Goodman, Ann. Missouri Bot. Gard. 21: 78. 1934.-TYPE: Chorizanthe parryi S. Wats., according to Art. 22.4 of the ICBN.

Plants prostrate to spreading; leaves basal, oblanceolate to narrowly oblong or narrowly elliptic; bracts foliaceous and similar to the leaves only reduced at the lower nodes, scalelike above; involucres urceolate, grayish pubescent with spreading hairs, without a scarious margin, the teeth of two sizes, awned; flowers white to rose, partially exserted from the involucre, slightly pubescent without, the tepals erose, rarely some entire or denticulate apically, those of the outer whorl longer and broader than those of the inner one; stamens 9, attached at the base of the tepals.

A taxon of disjunct distribution in the Transverse and Peninsular ranges of southern California and in west central Baja California Norte, México, from 150-2500 (4000) ft elev; flowering Mar-Jun.

\section{Key to the Species}

A. Involucral teeth uncinate or if straight then the longer awns 1-1.5 mm long; plants of southern California.

20. C. parryi

AA. Involucral teeth straight, the longer awns $1.5-3 \mathrm{~mm}$ long; plants of Baja California.

21. C. inequalis

The subsect. Parryanae (Charles Christopher Parry, 1823-1890, western American collector) is a small, isolated taxon that appears to be an extension of and more closely related to the subsect. Pungentes than to the subsect. Uniaristatae as suggested by Goodman (1934).

\section{Chorizanthe parryi S. Wats.}

Prostrate to spreading, strigose annual herbs 0.2-0.8 (1) dm high and 0.5-4 (6) dm across; leaves basal, oblanceolate to narrowly oblong, the blades $0.5-2.5$ (4) $\mathrm{cm}$ long, 2-6 (12) mm wide, thinly pubescent on both surfaces but somewhat more densely so below than above, acute to rounded apically, gradually tapering to a pubescent petiole $0.5-2(3.5) \mathrm{cm}$ long; inflorescences cymose, the involucres in small open clusters $0.3-1 \mathrm{~cm}$ across; bracts 2 , opposite, usually foliaceous, the blades $0.5-1.5 \mathrm{~cm}$ long, $1.5-7 \mathrm{~mm}$ wide, oblanceolate to elliptic, gradually reduced above and typically scalelike, linear, $1-5 \mathrm{~mm}$ long, 1-2 mm wide, aciculate, the awns 0.4-1 mm long, straight; involucres urceolate and slightly ventricose basally, 3-angled but 6-ribbed, grayish to reddish, corrugate, the tube $1.5-2 \mathrm{~mm}$ long, grayish pubescent with the longest hairs on the ridges, the longer three teeth 1-3 mm long, divergent, with an uncinate or straight awn $0.5-1.5 \mathrm{~mm}$ long, the smaller three obscure, $0.5-1 \mathrm{~mm}$ long, divergent or recurved, with the awns $0.2-0.5 \mathrm{~mm}$ long; flowers slightly exserted beyond the involucre, cylindric, $2.5-3 \mathrm{~mm}$ long, the tube greenish-white, the lobes white, sparsely pubescent without along the midribs with the hairs not exceeding the tepals, on pedicels $0.3-0.5 \mathrm{~mm}$ long, the tepals slightly dimorphic, the outer lobes oblong to oblong-obovate, rounded, erose or rarely 
some entire to denticulate, the inner lobes linear-oblanceolate, acute, entire or denticulate, about a third shorter than those of the outer whorl, united about two-thirds of their length; stamens 9 , included, the filaments $2-2.5 \mathrm{~mm}$ long, glabrous, white, the anthers $0.2-0.3 \mathrm{~mm}$ long, oval, white; achenes brown, 2.5-3 mm long.

Sandy places in the foothills of the Transverse and Peninsular ranges of Los Angeles and western San Bernardino cos., California, south into Orange and western Riverside Co., from 300-2500 (4000) ft elev, flowering from May-Jul.

\section{Key to the Varieties}

A. Involucral awns uncinate 20a. var. panyi

AA. Involucral awns straight. 20b. var. fernandina

We follow the general practice of dividing Chorizanthe parryi into two varieties (Jepson 1923; Goodman 1934; Abrams 1944; Munz 1959, 1974).

20a. Chorizanthe parryi S. Wats., Proc. Amer. Acad. Arts 12: 271. 1877, var. parryi.-TYPE: near Crofton, San Bernardino Co., California, 1876, Parry \& Lemmon 370 (holotype: GH!; isotypes: B, CAS, F, G, ISC, K, MIN, MO, NEB, NY, RSA, VT!).

Involucral awns uncinate.

Sandy places on the flats near and in the foothills of the San Gabriel, San Bernardino and San Jacinto mountains of Los Angeles, San Bernardino and Riverside cos., California, from 300-2500 (4000) ft elev, flowering from MayJun.

Representative Specimens: UNITED STATES. CALIFORnIA: Los Angeles Co.: Mt. Lowe, Jun 1902, Grant 171 (ARIZ, CAS, DS, G, ILL, MICH, RM, UC); W side of mouth of Latigo Canyon, 3 mi NW of Point Dume, Santa Monica Mountains, 27 Apr 1957, Thomas 6689 (DS); San Gabriel Wash, 26 May 1932, Wheeler 744 (MIN, ND, OKL, RSA); Thompson Creek Dam, near Claremont, 27 May 1932, Wheeler 765 (MIN, ND, OKL, RSA, UC). Riverside Co.: Harford Springs County Park, Gavilan Hills, 15 May 1980, Boyd 277 (UCR); Riverside, 12 May 1905, K. Brandegee s.n. (ARIZ, NESH, NMC, POM, RM, UC); San Gorgonio Wash near Banning, Little San Bernardino Mountains, 24 Jun 1933, Epling \& Robison s.n. (DS, LA, MO, RSA, UC, US); flat N of town of Lake Elsinore, 6 Apr 1962, Hardham 8951 (CAS, DAO); San Gorgonio Pass at Cabazon, 5 Jun 1931, J. T. Howell 6658 (CAS, MO, OKL); Palm Springs, 25 Mar 1920, Jaeger 1058 (POM); Banning, 11 May 1903, M.E. Jones s.n. (CAS, DS, POM); 5 mi NE of Murietta, 19 May 1922, Munz \& Johnston 5359 (POM, UC); San Gorgonio, Apr 1889, Parry s.n. (ISC, MO, NY); along Whitewater River, $3.2 \mathrm{mi} \mathrm{N}$ of Whitewater P.O. and Interstate 10, 28 May 1980, Thorne \& Tilforth 54226 (MARY, RSA, UCR). San Bernardino Co.: near Redlands, E end of San Bernardino Valley, 15-23 May 1913, Jepson 5537 (BM, JEPS, RM); Colton, 27 Apr 1882, M.E. Jones 3181 (ARIZ, BM, BR, CAS, DS, LE, MIN, MO, MSC, NY, POM, RM, UC, US, UTC); near San Bernardino, May 1881, Parish \& Parish 827 (BM, BR, DS, G, ISC, LE, NEB, UC, US, WU); near San Bernardino, 3 Jun 1895, Parish 3674 (G, GH, LE, NDG, UC); San Bernardino Valley, 23 Apr 1906, Parish 5593 (LA, MIN, NMC, ORE, RM); San Bernardino Valley, 21 May 1917, Parish 11219 (ARIZ, POM, UC, WTU); Colton, 29 May 1882, Pringle s.n. (F, G, GH, GOET, K, LE, LL, MICH, MPU, NY, PENN, PH, US, VT); Devore, E of Cajon Creek, 23 May 1988, Reveal 6867 (BM, BRY, CAS, MARY, MO, NY, OSC, RSA, US, WIS); E of Claremont, 2 Jun 1921, F. Robinson 71 (OKL, POM, RM, UC); Scott's Canyon, $2.5 \mathrm{mi}$ SE of Loma Linda, 11 May 1952, Roos \& Roos 5650 (RSA, UCR, UCSB); Arrowhead Hot Springs, 9 May 1919, Spencer 1103 (CAS, GH, NY, POM). Unknown Co.: without location data, 1881, Parry 269 (BM, F, G, K, LE, NY, ORE, VT). A total of 135 collections are known to us.

The var. parryi (Charles Christopher Parry, 1823-1890, early botanical collector in the American West and a student of Oxytheca, Chorizanthe and related genera) today is an infrequently collected taxon. It is found in a part of southern California where available habitats are rapidly disappearing. Grave concern should be given to the long-term survival of the variety. Many of the locations where the plant was found along the foothills surrounding the greater 
Los Angeles area have been dramatically altered over the last half century, and in the few places where the var. parryi has survived the extent of the available habitat is exceedingly limited.

20b. Chorizanthe parryi S. Wats. var. fernandina (S. Wats.) Jepson, Man. Fl. Pl. Calif. 298. 1923. Chorizanthe fermandina S. Wats., Bot. Calif. 2: 481. 1880.-TYPE: San Fernando Canyon, Los Angeles Co., California, Jun 1879, Bush s.n. (holotype: GH!; isotypes: CAS, K, US!).

\section{Involucral awns straight.}

Historically in sandy places on the foothills of the San Gabriel Mountains, Los Angeles Co., and near Santa Ana, Orange Co., California, from 700-1100 ft elev, flowering from May-Jun. Possibly extinct.

Specimens Examined: UNITED STATES. CALIForniA: Los Angeles Co.: Ballona Harbor, 1 Apr 1901, Abrams 1217 (DS); Chatsworth Park, 4 Apr 1901, Abrams 1337 (DS, POM, RM); San Fernando Wash, 11 May 1913, Eastwood 3139 (CAS, GH, NY, UC, US); near Elizabeth Lake, without date, H.M. Hall 7396 (UC); Newhall, 3 Jun 1893, Hasse s.n. (DS, NY); near Castaic, 27 Apr 1929, Hoffmann s.n. (SBBG); Elizabeth Lake, 9 Jul 1928 , Hoffmann s.n. (SBBG); river bed, Los Angeles, Apr 1884, Lyon s.n. (CAS); river bed, Los Angeles, Jun 1884, Lyon s.n. (DS); Los Angeles Valley, 1884, Nevin 1053 (GH); Little Tujunga Wash, 3 May 1920, Ouley 577 (JEPS); San Fernando, Jun 1887, Parish 1987 (DS, F, ISC, JEPS, NDG, US); San Fernando, 1881, Parry 267 (F); San Fernando, Aug 1881, Parry 267 (GH); Los Angeles, 1882, Parry s.n. (NY); near San Fernando, May 1882, Parry s.n. (MO, US); San Fernando, 1883, Parry s.n. (F, NY); San Fernadino Valley, Jun 1887, Parry 1987 (NY); Little Tujunga Wash just above the junction with Big Tujunga, SW base of San Gabriel Mountains, 3 May 1920, Peirson 2120 (RSA); San Fernando, 23 May 1882, Pringle s.n. (CAN, CAS, E, F, G, GH, K, LE, MICH, MIN, NY, PENN, PH, US, VT, WU); San Fernando, near the reservoir, 1922, E.S. Spalding s.n. (RSA). Orange Co.: without location data, 1902, Geis s.n. (DS); near Santa Ana, 1902, Geis 541 (DS). San Bernardino Co.: without location data, Apr 1876, Lemmon s.n. (BM, G). Unknown Co.: without location data, 1881, Parry s.n. (NY); without location data, 1882, Parry s.n. (F, G, GH, K, LE, MIN, NEB, NY, ORE, US); without location data, May 1882, Parry s.n. (MIN, UC); without location data, 1883, Parry s.n. (US); without location data, 188-, Parry s.n. (B, F, ISC); without location data, 18-, Parry 267 (MIN); without location data, 18--, Parry s.n. (ISC).

It is likely that the var. fernandina (from San Fernando, the type location) is now extinct. The plant was last collected in 1929 near Castaic. Numerous field botanists have been trying to rediscover it, but all efforts have been unsuccessful. The best potential site where the plant might be found is in the Elizabeth Lake area. We have included all of the specimens we have seen in the hope that these data will help others in their efforts to relocate extant populations of the taxon.

21. Chorizanthe inequalis S. Stokes, Zoe 5: 60. 1900.-TYPE: San Telmo, Baja California Norte, México, 31 May 1893, Brandegee s.n. (holotype: UC!; isotype: DS!).

Prostrate to spreading, thinly strigose annual herbs $0.2-0.8 \mathrm{dm}$ high and $0.5-4 \mathrm{dm}$ across; leaves basal, oblanceolate to narrowly elliptic, the blades (0.5) 1-2.5 (3) cm long, 2-5 (7) mm wide, thinly pubescent on both surfaces, acute to rounded apically, gradually tapering to a pubescent petiole $0.5-2 \mathrm{~cm}$ long; inflorescences cymose, the involucres in small open clusters 0.3-1 cm across; bracts 2, opposite, usually foliaceous, the blades $0.3-1(1.5) \mathrm{cm}$ long, $1.5-7$ $\mathrm{mm}$ wide, oblanceolate to elliptic, rapidly reduced above and typically scalelike, linear, $1-5$ $\mathrm{mm}$ long, 1-1.5 mm wide, aciculate, the awns 0.5-1 mm long, straight; involucres urceolate and slightly ventricose basally, 3-angled but 6-ribbed, grayish to reddish, corrugate, the tube 2-3 $\mathrm{mm}$ long, grayish pubescent with the longest hairs on the ridges, the longer three teeth 2-2.5 mm long, divergent, with straight awns $1.5-3 \mathrm{~mm}$ long, the smaller three obscure, 0.5-1 
$\mathrm{mm}$ long, divergent, with the awns $0.2-0.7 \mathrm{~mm}$ long; flowers slightly exserted beyond the involucre, cylindric, $2-2.5 \mathrm{~mm}$ long, the tube greenish-white, the lobes white to rose, sparsely pubescent without along the midribs with the hairs not exceeding the tepals, on pedicels 0.3-0.5 mm long, the tepals erose, slightly dimorphic, the outer lobes oblong to oblongobovate, rounded, the inner lobes linear-oblanceolate, acute, about a third shorter than those of the outer whorl, united about two-thirds of their length; stamens 9 , included, the filaments 1.5-2 mm long, glabrous, white, the anthers $0.4-0.5 \mathrm{~mm}$ long, obovate, rose to red; achenes brown, $1.8-2 \mathrm{~mm}$ long; $n=19$.

Sandy places on mesas along the coast and in the adjacent foothills from near Colonet south to San Quintín, Baja California Norte, México, from $150-300$ ft elev, flowering from Mar-May.

Specimens Examined: MÉXICO. Basa California Norte: San Telmo, 31 May 1893, Brandegee s.n. (DS, UC); near El Rosario on mesa above the sea, 15 May 1952, Creighton 502 (COLO); $100 \mathrm{mi}$ S of Ensenada, 14 Apr 1949 , Dressler 573 (GH, MO); 48 mi N of El Rosario, 18 Apr 1949, Dressler 690 (MO); San Telmo de Abajo, 3 Jun 1976, Moran 23438 (GH, NY, RSA, SD, US); 4 km N of El Carricito, 3 Jun 1976, Moran 23439 (MICH, SD); 4 km W of Los Alisos, 5 Jun 1976, Moran 23485 (COLO, MO, RSA, SBBG, SD, UCR); Los Alisos, 5 Jun 1976, Moran 23494 (SD); Arroyo del Rosario, 10 km NE of El Rosario, 6 Feb 1977, Moran 23919 (MSC, SD); Mesa el Pabellón, 11 May 1978, Moran 25924 (ASU, DAV, ENCB, MO, SD); $2.5 \mathrm{~km}$ S of Johnson Ranch, N of Cabo Colonet, 3 Jun 1979, Moran 27566 (LA, SD, UCR, W); Arroyo El Socorro, 4 mi from the mouth, 25 Feb 1973, Moran \& Reveal 20277 (ARIZ, ASU, COLO, DAV, GH, LL, MO, NY, RSA, SD, US); without location data, 17 Apr 1886 Orcutt s.n. (US); without location data, May 1886, Orcutt s.n. (MIN, MSC); without location data, 14 May 1886, Orcutt 1369 (BM, F, G, NY, PH, US); Salada, 14 May 1886, Orcutt 1369 (ISC, MO, MSC, NEB, PH); San Quintín Bay, Jan 1889, Palmer 651 (F, GH, K, LE, NY, PH, US, WU); 16 km SE of El Rosario, 18 Apr 1958, Raven et al. 12480 (GH, K, UC); $3.1 \mathrm{mi}$ E of San Telmo and $9.1 \mathrm{mi}$ E of México Highway 1 at San Telmo de Abajo, 20 May 1988, Reveal 6833 (BM, BRY, CAS, G, MARY, MEXU, MO, NY, OSC, RSA, US, WIS); Socorro Canyon, from sign post to beach, 9 Apr 1931, Wiggins 5222 (F, GH, LA, MICH, NY, POM, RM, UC, US).

Chorizanthe inequalis (Latin in-, not, and aequalis, like, same, not the same as $C$. parryi) is clearly related to $C$. parryi var. fernandina and differs mainly in having longer awns on a longer involucral tube bearing slightly shorter flowers and mature achenes. The differences are reinforced by a sharp geographic disjunction, but one that is probably evolutionarily rather recent. We suspect that $C$. inequalis represents an isolate expression of the var. fernandina that evolved during the late Pleistocene when the California flora was further south than present. The two expressions subsequently evolved in isolation with the minor morphological differences the result. Taxonomically it might be argued that $C$. inequalis would be better treated as a subspecies of $C$. parryi. Until Stokes (1900) recognized the taxon, and to some degree even after, plants of $C$. inequalis were often identified as $C$. parryi, and the relationship has never been questioned. Our reluctance to reduce the species is our desire to hope that var. fermandina will be rediscovered so that it might be studied cytologically and compared with its Mexican relative.

The chromosome number for this species was determined by Reveal to be $n=19$; his voucher was Reveal 6833.

IVA(6). Chorizanthe Benth. ex R. Br. subsect. Procumbentes Goodman, Ann. Missouri Bot. Gard. 21: 84. 1934.-TYPE: Chorizanthe procumbens Nutt., according to Art. 22.4 of the ICBN.

Plants prostrate to decumbent; leaves basal, oblanceolate; bracts foliaceous and similar to the leaves only reduced at the lower nodes, scalelike above; involucres cylindric to slightly campanulate, thinly pubescent, without a scarious margin, the teeth occasionally of two sizes, 
awned; flowers white or yellow, exserted from the involucre, slightly pubescent without, the tepals entire, both whorls usually equal; stamens 9 , the filament basally united into a short tube.

A highly variable monospecific taxon of the hills and measas near the coast and inland foothills of southern California from Ventura, Los Angeles and western San Bernardino cos., California, southward to the San Quintín area of west-central Baja California Norte, México, from near sea level to $2500 \mathrm{ft}$ elev; flowering from Apr-Jun.

22. Chorizanthe procumbens Nutt., Proc. Acad. Nat. Sci. Philadelphia 4: 17. 1848.-TYPE: San Diego, San Diego Co., California, Apr 1836, Nuttall s.n. (holotype: PH!; isotypes: $\mathrm{BM}, \mathrm{GH}, \mathrm{K}$ !).

Chorizanthe uncinata Nutt., Proc. Acad. Nat. Sci. Philadelphia 4: 17. 1848.-TYPE: San Diego, San Diego Co., California, Apr 1836, Nuttall s.n. (holotype: PH!; isotypes: BM, GH, K, PH!).

Chorizanthe procumbens Nutt. var. albiflora Goodman, Ann. Missouri Bot. Gard. 21: 87. 1934.-TYPE: 2 mi E of Pala, San Diego Co., California, 30 Apr 1926, Munz 10372 (holotype: POM!).

Chorizanthe procumbens Nutt. var. mexicana Goodman, Ann. Missouri Bot. Gard. 21: 87. 1934. - TYPE: Tecate, Baja California Norte, México, 30 May 1932, Fosberg 8281 (holotype: MO!; isotypes: NO, OKL!).

Chorizanthe jonesiana Goodman, Ann. Missouri Bot. Gard. 21: 88. 1934. - TYPE: 29 miles southwest of Tiajuana, Baja California Norte, México, 13 Apr 1925, M.E. Jones s.n. (holotype: POM!; isotypes: DS, POM!).

Chorizanthe chaetophora Goodman, Ann. Missouri Bot. Gard. 21: 88. 1934.-TYPE: San Quintín Bay, Baja California Norte, México, Jan 1889, Palmer 652 (holotype: PH!; isotypes: ARIZ, F, GH, K, LE, MICH, NY, US!).

Prostrate to decumbent, thinly pubescent annual herbs 0.2-0.8 dm high and 0.5-4 (5) dm across; leaves basal, oblanceolate, the blades (0.5) 1-3 (4) cm long, (0.8) 1-7 (12) mm wide, thinly pubescent on both surface, acute to rounded apically, usually tapering to a pubescent petiole 0.5-2 (3) cm long; inflorescences cymose, the involucres in small, open clusters 0.3-1 cm across, greenish- or grayish-yellow; bracts 2, opposite, foliaceous at the lowermost nodes and similar to the leaves only more reduced, 3-10 (15) mm long, 1.5-5 (8) mm wide, linearoblanceolate to elliptic, rapidly reduced above and typically scalelike, $1-5 \mathrm{~mm}$ long, (0.3) 0.5-3 $\mathrm{mm}$ wide, linear and acicular, often acerose, the straight awns $0.2-1 \mathrm{~mm}$ long; involucres cylindrical or narrowly to broadly campanulate, 3-angled but 6-ribbed, greenish-yellow to reddish-green, faintly corrugate, the tube $1.5-3 \mathrm{~mm}$ long, thinly pubescent with spreading hairs, the longest hairs on the ridges and at the base, with a thin, hyaline margin between the teeth, the teeth equal and spreading, 1-2.5 mm long, or of two distinct sizes and usually divergent with thickened bases, 2.5-5 mm long, alternating with smaller teeth 1-2 mm long, the recurved to uncinate awns $0.2-0.5 \mathrm{~mm}$ long; flowers exserted from the involucre, cylindric, (1.7) $2-3 \mathrm{~mm}$ long, white or more commonly yellow, pubescent without nearly the entire length of the midrib with the hairs sometimes extending beyond the apex, on pedicels 0.3-0.7 mm long, the tepals monomorphic or nearly so, narrowly oblong to narrowly obovate, occasionally with the outer tepals slightly broader and longer than the inner ones, the lobes entire, united about two-thirds of their length; stamens 9 , included to slightly exserted, the filaments (0.3) 0.5-2.5 mm long, united into a pilose-ciliate tube $0.2-1 \mathrm{~mm}$ long, white, the anthers $(0.2)$ 0.5-0.7 mm long, oblong, cream to pale yellow; achenes brown, narrow, 1.5-2.5 mm long; $n=$ (19) 20 (21-23). 
Sandy to gravelly places on the mesas and foothills of the Santa Monica, San Gabriel and San Bernardino mountains of Ventura, Los Angeles and San Bernardino cos. south through western Riverside and Orange cos. to San Diego Co., California, and in Baja California Norte, México, from near the coast east to the Tecate Mountains area southward along the coast and in the mountains to the San Quintin area, from (15) $50-2500 \mathrm{ft}$ elev, flowering from Apr-Jun.

Representative Specimens: MÉXICO. BAJA CALIFORnIA NORTE: N slope of Cerro Blanco, 15 Jun 1969, Moran 16141 (MO, RSA, SD, UC, US); 0.5 mi W of Rancho el Criprés, 7 May 1973, Moran 20908 (RSA, SD, US); 10 mi E of Uruapan, 22 May 1973, Moran 21009 (ASU, CAS, COLO, ENCB, MEXU, SD, UCR); W of Rocky Point, Bahía San Quintín, 20 Apr 1975, Moran 21828 (COLO, GH, LL, MARY, MICH, MO, MSC, RM, RSA, SD, US, W); 5 mi NW of Bahía San Quintín , 21 Apr 1975, Moran 21843 (ARIZ, MEXU, RSA, SD, UC); 1 mi from San Telmo, 17 May 1975, Moran 21978 (MARY, RSA, SD, UCR); 6.5 mi S of Erendira, 19 May 1975, Moran 22016 (CAS, ENCB, LL, MICH, SD); El Coyote, Sierra San Pedro Martír, 3 May 1976, Moran 23082 (SBBG, SD); 3.5 km E of El Rodeo, 7 km N of Cabo Colonet, 3 Jun 1979, Moran 27599 (SD); Carisito, 29 May 1883, Orcutt s.n. (F, GH, VT); $14 \mathrm{~km} \mathrm{NW}$ of Colonia Guerrero, 4 Apr 1958, Raven et al. 12196 (GH, K, UC); on the NW edge of a volcanic ridge $6.7 \mathrm{mi}$ W of México Highway 1 at San Quintín, 20 May 1988, Reveal 6831 (BRY, CAS, MARY, MEXU, MO, NY, RSA, US); 3 mi E of Uruapan, 21 May 1988, Reveal 6836 (CAS, MARY, MO, RSA); along México Highway 3, $7.1 \mathrm{mi}$ SW of Francisco Zarco, 21 May 1988, Reveal 6844 (CAS, MARY, MEXU, MO, RSA); along the ridge SE of Pico Banda, 0.8 airline mi N of La Bufadora, 26 Mar 1988, Reveal \& Broome 6774 (BM, BRY, CAS, MARY, MICH, MO, NY, RM, RSA, US, WIS); along México Highway 1D, 8.7 mi N of Punta Piedra, 26 Mar 1988, Reveal \& Broome 6775 (BM, CAS, MARY, MO, NY, RM, RSA, US, WIS); along the dirt road from San Quintín to Cabo San Quintín, $7 \mathrm{mi}$ W and S of México Highway 1, 25 Mar 1988, Reveal et al. 6759 (ARIZ, ASU, BM, BR, BRY, CAS, F, GH, ILL, K, LE, MARY, MEXU, MICH, MO, NY, ORE, RM, RSA, US, TEX, UTC, WIS). low ridges SW of San Telmo, 25 Mar 1988, Reveal et al. 6764 (ARIZ, ASU, BM, CAS, F, GH, ILL, K, MARY, MICH, MO, NY, ORE, RM, RSA, US, UTC, WIS); coastal bluffs 20 mi S of Tia Juana near Rancho Cuevas, 3 Apr 1931, Wiggins 5116 (ARIZ, CAS, DS, GH, LA, LL, MICH, MO, NY, POM, RM, UC, US). UNITED STATES. CALfForniA: Los Angeles Co.: bluffs overlook ocean at Carlsbad, 1 May 1937, Barneby $372 / 37$ (K); Roscoe, 27 May-10 Jun 1906, Eastwood 258 (CAS, GH); near junction of Foothill Boulevard and Irwindale Avenue, Irwindale, 7 Apr 1986, LaPre \& Mulroy s.n. (UCR); Claremont, 13 May 1919, Munz 2790 (DS, POM); Arroyo Seco, San Gabriel Mountains, 21 May 1919, Peirson 446 (JEPS, RSA); Thompson Creek Dam near Claremont, 27 May 1932, Wheeler 766 (MO, ND, OKL, RSA). Orange Co.: Pelican Hill, Irvine Ranch, San Joaquin Hills S of Corona del Mar, 13 May 1981, Boyd s.n. (UCR); between Dana Point and Laguna Beach, 24 Apr 1937, Eastwood \& Howell 3938 (CAS, F, MICH, NY); 0.5 km W of Dana Point Harbor, 0.8 km SSW of the R.H. Dana School, Dana Point Headlands, 24 Apr 1983, F.M. Roberts 1006 (UCSB). Riverside Co.: above Elsinore, Santa Ana Mountains, 24 Apr 1937, Eastwood \& Howell 3911 (CAS); Santa Ana Mountains, San Juan Canyon near the Ortega Highway on road to Santiago Peak, 18 Jun 1935, Everett 7173 (NY, OKL, RSA); near Temecula Canyon at the intersection of U.S. Highway 395 and the road to Rainbow, 6 Apr 1962, Hardham 8949 (CAS, RSA, SBBG). San Bernardino Co.: N of Upland, 14 May 1953, Breitung 15057 (DAO); Highland Avenue, E of Upland, 11 Jun 1927, J. T. Howell 2481 (CAS); near San Bernardino, 20 May 1895, Parish 3663 (ARIZ, CAS, G, GH, LE, NDG, UC, US); San Bernardino Valley, 2 Jun 1906, Parish 5776 (BKL, LA, ORE, RM); San Bernardino Valley, May 1882, Parish \& Parish 826 (BR, DS, LE, WS); Colton, 1881, Pary 270 (E, F, GH, ISC, NY, US, VT); Lucerne Valley, 2 mi S of Lucerne on Bear Valley Road, 14 May 1966, S. Walker s.n. (UCR). San Diego Co.: near Potrero, 3 Jun 1903, Abrams 3737 (DS, E, F, G, GH, K, MIN, NY, PH, POM, UC); Witch Creek, Jun 1894, Alderson s.n. (DS, MICH, UC); San Diego, 25 May 1902, Brandegee 1638 (B, BKL, G, GH, K, LE, MICH, MIN, NY, POM, RM, UC, US); Point Loma, Jun 1906, K. Brandegee 29 (ARIZ, BM, CAN, COLO, DS, E, F, G, GH, K, L, MO, NESH, PH, POM, RM, UC, US, WTU); La Jolla, 23 May 1914, Clements \& Clements 49 (COLO, F, GH, MICH, MO, NEB, NY, PENN, PH, UC, UCSB); Point Loma, 21 Apr 1913, Eastwood 2874 (CAS, GH, NY, UC, US); Red Mountain Grade, 11 May 1937, Gander 3786 (SD); Kearney Mesa, 2 Apr 1962, Hardham 8938 (CAS, SBBG); 6.5 air mi SSE of Fallbrook, 3 mi E of Bonsal, 18 May 1973, Henrickson 9914 (CHSC, HSC, RSA); Soledad, 20 Apr 1882, M.E. Jones 3159 (B, BM, BR, CAS, DS, ILL, LE, MO, MSC, NY, POM, UC, US, UTC); mesas, San Diego, 8 May 1884, Orcutt s.n. (MICH, MIN, PENN); San Diego, 1875, Palmer 354 (BM, F, G, LE, NY); San Diego, 1882, Parry 270 (F, GH, MIN, NY, VT); Silver Strand, S of Coronado, 30 Mar 1935, Purer 6152 (CM, GH, RSA); 0.4 mi E of California Highway 188, $1.2 \mathrm{mi}$ N of Tecate, 21 May 1988, Reveal 6851 (CAS, MARY, RSA); along Rainbow Heights Road, $1 \mathrm{mi}$ E of Old U.S. Highway 395 in Rainbow, 22 May 1988, Reveal 6859 (CAS, MARY); near San Diego, 30 May 1916, Spencer 33 (GH, K, MICH, UC, US); $4.7 \mathrm{mi}$ E of the N end of El Capitan Lake near junction of road to Rancho Alegria, 15 Jun 1954, J.M. Tucker 2717 (ARIZ, DAO, DAV, MIN, WTU); foot of Cuca Grade above Rincon, Palomar Mountains, 14 Jun 1928, Wiggins 3090 (DS, LA, UC). Ventura Co.: Sespe, 11 May 1882, M.E. Jones s.n. (POM). A total of 260 collections are known to us. 
This subsection has proved to be a never ending source of frustration. Goodman (1934) recognized three species, as did Wiggins (1980) who provided an excellent key to them. We have vacillated from one to three and at this moment we are in our "it's impossible" stage and have given up trying to differentiate among them.

When Nuttall (1848) described Chorizanthe procumbens (from the Latin procumbens, prostrate, as to the growth habit) he mentioned a second species that he acknowledged was closely related; this he named $C$. uncinata. Bentham (1856) reduced the latter to synonymy where all subsequent authors have placed it. What Nuttall observed in the field was also detected by Goodman (1934) in the herbarium who redescribed Nuttall's C. procumbens as $C$. jonesiana. When Goodman did so, however, he applied the name $C$. procumbens to the expression Nuttall had called $C$. unicinata, and $C$. jonesiana to the expression Nuttall had termed $C$. procumbens.

The two do differ from one another. At their extremes, Chorizanthe procumbens, sensu Goodman is a small plant with a cylindrical involucre terminated by uncinate awns containing rather short flowers (1.7-2.3 mm long) with essentially equal tepals that are pubescent along the midribs where the hairs exceed the apex of the tepal. This is the more northern phase of the species. Chorizanthe jonesiana, or C. procumbens sensu Nuttall, is a large plant with a campanulate involucre terminated by straight or curved awns containing longer flowers (2.5-3 mm long) with slightly unequal tepals that are pubescent along the midribs where the hairs do not exceed the apex of the tepal. This is the more southern phase of the species.

Near the coast from San Diego to south of Ensenada both species as defined by Goodman (1934) can be found either singularly or together. Further to the east, in the mountains, the two extremes tend to be found less often growing together.

Our study of Chorizanthe procumbens complex demonstrated that wherever the two extremes occurred together one can find a series of intermediates. Such intermediates were not hybrids but represented different stages of development and maturity. The older or larger the individual, the closer it was to the concept of $C$. jonesiana. If an individual was subjected to stress (especially aridity), it tended to retain the aspect of $C$. procumbens sensu Goodman. Conversely, an individual subjected to less stress, even when rather immature, tends to resemble $C$. jonesiana.

Coupled with these observations are a myriad of chromosome numbers. Hardham (1989) found a series of aneuploid numbers ranging from $n=19-23$ with the tetraploid, $n=20$, the most common. What impact these aneuploids have on the variation cannot be determined at this time.

If one wished to distinguish between the two morphological extremes, it is critical to note that the type of Chorizanthe procumbens would encompass the $C$. jonesiana phase while $C$. uncinata would include the $C$. procumbens phase as circumscribed by Goodman (1934) and all recent authors (Abrams 1944; Munz 1959, 1974; Wiggins 1980). These authors have all failed to recognize the existence of the $C$. jonesiana expression in the San Diego area.

Goodman (1934) also recognized a third element in the extreme southern part of the complex's range that he termed Chorizanthe chaetophora. This plant has the aspect of $C$. jonesiana but differs in having a more grayish tinge to its stems, branches and pubescence compared to the greenish-yellow tinge of that expression. Like that species, $C$. chaetophora is a larger, more spreading plant with campanulate involucres bearing large flowers. These two expressions occur together on and in the vicinity of Mesa San Antonio del Mar. In this area, the plants closer to the sea or at lower elevations tend to be more like the type of $C$. chaetophora while those further inland or at higher elevations more more akin to $C$. jonesiana. Again it appears that the extremes are environmentally induced rather than distinct taxonomic 
units.

The differences in flower color emphasized by Goodman (1934) with the recognition of var. albiflora do not hold. In southern Riverside and northern San Diego cos. one can observe all stages of gradiation between white and yellow intermixed in a single population. Elsewhere an occasional plant will have white flowers, and some are so pale a yellow that the difference between that and white can only be told against a white background. Goodman's montane var. mexicana with its slightly more slender involucral awns is nothing more than a more slender, luxuriant form that can be found away from the coast in almost any population of the species from San Diego Co. southward.

IVA(7). Chorizanthe Benth. ex R. Br. subsect. Staticoideae Goodman, Ann. Missouri Bot. Gard. 21: 51. 1934.-TYPE: Chorizanthe staticoides S. Wats., according to Art. 22.4 of the ICBN.

Plants decumbent, spreading to erect; leaves basal, elliptic, oblong to oblong-ovate or ovate; bracts foliaceous and similar to the leaves only reduced at the lower nodes, scalelike above; involucres cylindrical, thinly pubescent, without a scarious margin, the teeth of two sizes, awned; flowers white to rose or red, slightly exserted from the involucre, slightly pubescent without, the tepals entire, those of the outer whorl equal or only slightly longer and broader than those of the inner one; stamens 6 or 9 , attached at the base of the tepals.

A taxon of five species of the Coast Ranges and Sierra Nevada from Monterey and Merced cos., California, south in the Peninsular Ranges to extreme north-central Baja California, México, and on the off-shore islands in southern California, from near sea level to 5600 (6000) ft elev, flowering from Apr-Aug.

\section{Key to the Species}

A. Lower foliaceous bracts soon deciduous or lacking.

B. Flowers 3-4 (5) mm long, slightly exserted from the involucre; involucres arranged in congested clusters; Coast Ranges from Monterey Co. south to the Transverse Ranges of Santa Barbara Co. eastward to western San Bernardino Co., Santa Catalina Island, and in the Peninsular Ranges of western Riverside and Orange cos. south along the immediate coast into San Diego Co. 23. C. staticoides

BB. Flowers 4.5-6 mm long, well exserted beyond the involucre; involucres solitary; San Jacinto Mountains of western Riverside Co., south through the Laguna Mountains of San Diego Co., California, to just south of the Mexican boundary in the Tecate Mountains.

24. C. leptotheca

AA. Lower foliaceous bracts persistent.

B. Flowers $4.5-6 \mathrm{~mm}$ long, well exserted beyond the involucre; involucral tube $3-4.5 \mathrm{~mm}$ long, pubescent with thin slender hairs; non-serpentine soils in the inner Coast Ranges and Sierra Nevada of Monterey and Merced cos., California, south to the Transverse and Tehachapi ranges of Santa Barbara, Ventura and Los Angeles cos. eastward to western San Bernardino and central Riverside cos. in the San Jacinto Mountains 25. C. xantii

BB. Flowers $2.5-3.5 \mathrm{~mm}$ long, slightly exserted from the involucre; serpentine soils of San Luis Obispo Co. or the off-shore islands in Santa Barbara Co., California.

C. Flowers 3-3.5 mm long; involucres 2.5-3 mm long, pubescent with slender hairs; bracts oblong-ovate to ovate; stamens 9; serpentine outcrops, San Luis Obispo Co. 26. C. breweri

CC. Flowers $2.5-3 \mathrm{~mm}$ long; involucres $2-2.5 \mathrm{~mm}$ long, sparsely pubescent with stout curled hairs; bracts lanceolate to oblong; stamens 6; Santa Cruz and Santa Rosa islands, Santa Barbara Co.

27. C. wheeleri

Goodman (1934) defined his subsect. Staticoides (from the Greek statikos, causing to stand, and eidos, like or similar to, alluding to the similarity of this species to plants of the genus Statice in the Plumbaginaceae) to include not only the five species noted herein, but 
Chorizanthe fimbriata as well. We prefer to place that species in the subsect. Flavae. As now circumscribed, the subsect. Staticoideae consists of a group of closely related species that are rarely sympatric and distinguished one from another on ecological and morphological differences. All of them probably have the same aneuploid chromosome number of $n=19$.

23. Chorizanthe staticoides Benth., Trans. Linn. Soc. London 17: 418. 1836.-TYPE: without location data, but probably from the Santa Lucia Mountains near Monterey, Monterey Co., California, "1833," Douglas s.n. (holotype: K!; isotypes: BM, CGE, GH, K, LE, MO, OXF!).

Chorizanthe nudicaulis Nutt., Proc. Acad. Nat. Sci. Philadelphia 4: 17. 1848. Chorizanthe staticoides Benth. var. nudicaulis (Nutt.) Jepson, Fl. Calif. 1: 394. 1913.-TYPE: Santa Barbara, Santa Barbara Co., California, 1842, Gambel s.n. (holotype: PH!; isotypes: K, $\mathrm{PH} !)$.

Chorizanthe discolor Nutt., Proc. Acad. Nat. Sci. Philadelphia 4: 17. 1848.-TYPE: San Diego, San Diego Co., California, 1842, Gambel s.n. (holotype: PH!; isotypes: BM, GH, $\mathrm{K} !)$.

Chorizanthe staticoides Benth. f. bracteata Goodman, Ann. Missouri Bot. Gard. 21: 54 . 1934. - TYPE: Red Reef Canyon, Topatopa Mountains, 2800-3500 ft elev, Ventura Co., California, 8 Jun 1908, Abrams \& McGregor 146 (holotype: DS!; isotypes: E, G, GH, NY, US, Z!).

Chorizanthe staticoides Benth. var. brevispina Goodman, Ann. Missouri Bot. Gard. 21: 55. 1934. - TYPE: near Deer Park, Monrovia Canyon, San Gabriel Mountains, Los Angeles, California, 10 Jun 1928, J. T. Howell 3876 (holotype: MO!; isotypes: B, CAS, GH, K, NY!).

Chorizanthe staticoides Benth. var. elata Goodman, Ann. Missouri Bot. Gard. 21: 55. 1934. - TYPE: Glen Ivy Trail to Santiago Peak, Santa Ana Mountains, Riverside Co., California, $4800 \mathrm{ft}$ elev, 14 Jun 1923, Munz 7085 (holotype: POM!; isotype: UC!).

Chorizanthe staticoides Benth. var. latiloba Goodman, Ann. Missouri Bot. Gard. 21: 57. 1934. - TYPE: Acton, Los Angeles Co., California, Jun 1902, Elmer 3689 (holotype: MO!; isotypes: COLO, DS, E, F, G, GH, K, MICH, MIN, POM, US, VT, WIS, Z!).

Chorizanthe chrysacantha Goodman, Ann. Missouri Bot. Gard. 21: 57. 1934. Chorizanthe staticoides Benth. subsp. chrysacantha (Goodman) Munz, Aliso 4: 89. 1958. - TYPE: bluffs along the coast, Laguna Beach, Orange Co., California, $50 \mathrm{ft}$ elev, 17 Apr 1920, Munz \& Harwood 3775 (holotype: POM!).

Chorizanthe chrysacantha Goodman var. compacta Goodman, Ann. Missouri Bot. Gard. 21: 58. 1934. - TYPE: beach bluffs between Laguna and Newport, Orange Co., California, 27 Apr 1928, Reed 5700 (holotype: POM!).

Erect to spreading or ascending, thinly pubescent annual herbs $0.5-6 \mathrm{dm}$ high and $0.5-3$ (5) $\mathrm{dm}$ across; leaves basal or slightly sheathing up the stems, oblong to oblong-ovate, the blades $0.5-3(8) \mathrm{cm}$ long, 3-10 (25) $\mathrm{mm}$ wide, thinly pubescent to glabrous on the upper surface, usually rather densely tomentose below, obtuse to rounded apically, usually tapering to a pubescent petiole 1-3 (4) cm long; inflorescences cymose, mostly flat-topped and open to densely branched, reddish or greenish; bracts 2 , opposite, reduced and scalelike to occasionally foliaceous at the lowermost nodes and similar to the leaves only more reduced, (1) 2-5 (10) $\mathrm{mm}$ long, 1-3 (6) $\mathrm{mm}$ wide, the foliaceous ones soon deciduous, obovate and short petiolate, otherwise linear and acicular, often acerose, the straight awns 0.5-2 mm long; involucres usually congested terminally and sometimes densely so, with a solitary one at the 
node of the dichotomies, reddish or greenish, often irregularly corrugate, the tube cylindrical, 3-angled but 6-ribbed, 3-4 (5) mm long, thinly pubescent with slender curly hairs to glabrate, the teeth spreading, 0.7-1.3 (1.5) $\mathrm{mm}$ long, the longer three with the anterior one longer and more erect than the others, these alternating with the three shorter and less prominent ones, the uncinate awns 0.5-1 mm long; flowers included to just slightly exserted, cylindric, 3-4 (5) $\mathrm{mm}$ long, rose to red, infrequently with white lobes, pubescent without nearly the entire length of the midrib with the hairs usually extending to the apex, sessile or on pedicels $0.1-0.2$ $\mathrm{mm}$ long, the tepals monomorphic to slightly dimorphic, oblong to obovate, with the outer tepals usually slightly broader and longer than the inner ones, the lobes rounded to obtuse or truncate apically, occasionally irregularly denticulate, united about half their length; stamens 9, mostly included, the filaments $2.5-4(4.5) \mathrm{mm}$ long, glabrous, reddish, the anthers 0.5-0.6 mm long, oblong, pink to red; achenes brown, narrow, 3-4 mm long; $n=19(20-21)$ (Hardham 1989).

Sandy to gravelly or rocky places mainly in the foothills and mountains of the coastal ranges of western California from Monterey Co. in the Santa Lucia Mountains south to the Santa Ynez Mountains of Santa Barbara Co. then eastwardly in the mountains and near the coast across Ventura and Los Angeles cos. to the San Bernardino Mountains of San Bernardino Co., south to the Santa Ana Mountains of Riverside and Orange cos., with a series of disjunct populations on Santa Catalina Island and along the coast and adjacent foothills of Orange and San Diego cos., from (10) 50-5600 (6000) ft elev, flowering from Apr-Jul.

Representative Specimens: UNITED STATES. CALIFORNIA: Los Angeles Co.: Sepulveda Canyon, Santa Monica Mountains, 16 Jun 1902, Abrams 2554 (BM, DS, E, F, G, GH, K, MIN, MO, NMC, NEB, NY, PH, POM, US, Z); Sierra Madre, 2 Jul 1902, Abrams 2637 (DS, E, F, GH, K, MIN, NY, POM); near Claremont, May 1904, C.F. Baker 4706 (E, G, K, MIN, NY, POM, US); Mandeville Canyon, Santa Monica Mountains, May 1929, Clokey \& Templeton 4491 (CM, G, GH, K, LE, MICH, MIN, MO, MONTU, ND, NO, NY, PENN, POM, RM, UC, US, WTU); Mandeville Canyon, Santa Monica Canyon, Apr 1929, Clokey \& Templeton 4494 (F, ILL, K, MARY, MIN, ND, NY, OKL, PENN, POM, UC); Los Alisos Canyon, 30 May 1931, Epling \& Dunn s.n. (BM, BR, GH, K, MARY, MIN, NO, NY, OKL); S end of Verdugo Canyon, Santa Monica Mountains, 21 Jun 1929, Ewan 3645 (DS, NO, OKL); Upper Millards Canyon, San Gabriel Mountains, 4 Jul 1932, Ewan 7586 (GH, MO, NO, PH); Higgins Canyon, Santa Monica Mountains, Apr 1933, Ewan 10932 (BM, ISC, NO, WTU); E end of Barley Flats, 23 Jul 1933, Ewan \& Dunn 7838 (GH, MO, NO, RSA); Pasadena, 17 Jun 1904, Grant s.n. (CAS, DS, E, F, ILL, MARY, MIN, NESH, NMC, NY, OKL, PH, POM, RM, UC, WIS); Santa Susanna Pass, 29 May 1931, J. T. Howell 6585 (CAS, RSA); near Claremont, 21 May 1926, M.E. Jones s.n. (CAS, DS, NY, US); San Dimas Canyon, 21 Apr 1920, Munz \& Hanwood 3715 (POM, RM, US); Sepulveda Canyon, Santa Monica Mountains, 15 May 1920, Munz \& Hanwood 3924 (DS, PH, POM, RM); San Francisquito Canyon, Jun 1887, Parish 1988 (DS, ISC, MO, UC); Mulholland Highway, $0.9 \mathrm{mi}$ W of Seminole Hot Springs, Santa Monica Mountains, 1 May 1962, Raven 17519 (DS, RSA, US); Castaic, near the junction of Charlie Canyon and Tapia Canyon roads, 24 May 1988, Reveal 6869 (BM, BRY, CAS, G, MARY, MO, NY, OSC, RM, RSA, UTC, WIS); Bouquet Canyon, San Gabriel Mountains, 14 May 1927, Stason s.n. (DS, GH, NY, UC, US); central part of Cape Canyon, Santa Catalina Island, 29 May 1968, Thorne \& Propst 37686 (ASU, GH, MO, RSA, SD); Soledad Canyon Road, $1.8 \mathrm{mi}$ NE of Solemint, 12-15 May 1961, Weiler \& Taylor 61113 (BR, ENCB, RM, TEX, UC); San Dimas Canyon, San Gabriel Mountains, 12 Jun 1932, Wheeler 821 (G, MIN, ND, OKL, RSA, UC); Santa Clara Valley, 1 mi W of Castaic Junction, 26 May 1936, Wolf 7829 (ARIZ, CAS, DS, GH, IDS, LA, MIN, NY, OKL, RSA, WS). Monterey Co.: Nacimiento-Ferguson Road, $0.8 \mathrm{mi}$ E of the Nacimiento Guard Station, 17 Jun 1978, Broome \& Cagle 2167 (CAS, MARY, RSA); Burro Trail, E slope of the Santa Lucia Mountains, 9 Jun 1909, K. Brandegee s.n. (DS, MO, NESH, RM, UC, US); Tassajara Hot Spring, Jun 1901, Elmer 3251 (COLO, DS, G, K, MICH, MIN, MO, ORE, US, VT, WIS, Z); 0.7 mi N of Tassajara Hot Springs, Santa Lucia Mountains, 8 Jul 1956, Ferris \& Ernst 13018 (CAS, DS, GH, NY, UC, WS); S trail to Cone Peak, Santa Lucia Mountains, 18 Jun 1955, Munz 20936 (CAS, NY, RSA); above Jolon, San Lucia Mountains, 25 Jun 1945, Ripley \& Barneby 6978 (CAS, NY); 0.2 mi S of Plaskett Camp on Plaskett Ridge, Santa Lucia Mountains, 11 Jun 1970, Twisselmann 16663 (CAS, DAO, RSA). Orange Co.: Corona del Mar, S of Newport Bay, 12 May 1932, L.M. Booth 1031 (JEPS, NO, POM, UC); Pelican Hill, Irvine Ranch, San Joaquin Hills S of Corona del Mar, 13 May 1981, Boyd s.n. (UCR); Elsinore Mountains, lookout at the top, 4 Jun 1944, N.C. Cooper 1323 (LA, RSA); bluffs along shore, Laguna Beach, 5 May 1916, Crawford s.n. (MO, POM, UC, US); Santa Ana Canyon, 0.7 mi W of Esperanza, 29 Apr 1935, Everett 6711 (ARIZ, DS, GH, OKL, RSA, WTU); hills near San Clemente, 
5 Apr 1962, Hardham 8957 (CAS); Santa Ana Canyon, 8 Jun 1927, J. T. Howell 2461 (CAS, RSA, US); 5 mi below Laguna, 25 Apr 1926, Mason 2913 (DS, GH, MO, NY, UC); Newport Bay, 25 Jun 1932, Wheeler 856 (ND, RSA). Riverside Co.: Bachelor Mountain, E end of Lake Skinner, 1 May 1986, Boyd 1812 (COLO, HSC, NY, RSA, TEX, UCR); Main Divide Truck Trail between El Cariso and San Mateo Canyon, Santa Ana Mountains, 2 Jun 1968, Lathrop 6955 (RSA). San Bernardino Co.: Day Canyon, San Bernardino Mountains, near Gaging Station, 24 May 1971, Benny \& Wainwright 504 (RSA); Etiwanda, May 1928, Fosberg 624 (PH); City Creek Road to Big Bear Lake, 28-30 Jul 1930, Hitchcock \& Goodman $17 \neq 8$ (MO, NY, OKL, RM); Barranca, 10 Jun 1929, Kraebel s.n. (SBBG, UCSB); Crofton Hills, Apr 1876, Lemmon 3101 (GII, JEPS); San Bernardino Valley, 2 Jun 1919, Parish 19294 (CAS, DS, GH, UC); without location data, 1876, Parry \& Lemmon 369 (CAS, F, G, ISC, JEPS, MIN, MO, NY, VT, WIS); Arrowhead Hot Springs, 7 May 1919, Spencer 1102 (CAS, GH, NY, POM); Crestline, San Bernardino Mountains, 12 Jul 1930, Templeton 1673 (BRY, L, NY, RSA); Chapman Ranch above Baldy Village, San Gabriel Mountains, 2 Jul 1967, Thorne \& Thorne 37245 (DAO, G, RSA, UC, Z). San Diego Co.: Torrey Pine, May 1926, Ackley s.n. (SBBG); S end of Torrey Pines State Reserve, 21 Apr 1971, Beauchamp 2208 (SD); 2.5 mi E of Encinitas on road to Olivenhain, 27 May 1937, Gander 3866 (POM, SD); 4 mi E of Carlsbad, 16 May 1954, Haig s.n. (RSA); San Diego, 1882, Parry s.n. (GH, ISC, MIN); Franklin Canyon, 6 May 1928, Thackery 305 (F, DS, MO, NY, SMU). San Luis Obispo Co.: 7.5 mi E of Santa Margarita on North Circuit Road, Park Hill District, 25 May 1955, Ferris 12832 (DS, RSA, UC, WTU); 8 mi E of Santa Margarita near Highway 178, 12 May 1938, Ferris \& Rossbach 9441 (DS, F, GH, MICH, ORE, RSA, UC, WTU); La Panza District, 2 Jun 1946, Hoover 6124 (CAS, OBI, OKL); La Panza Range, NW of Black Mountain along Indian Creek, 26 May 1988, Reveal \& Hardham 6915 (BRY, CAS, MARY, MO, NY, OSC, RSA, WIS); 3 mi S of U.S. Highway 101 on Cuesta Summit Road, 10 May 1962, Rodin 6875 (OBI, UCR); Atascadero-Morro Road, 27 Jun 1933, Winblad s.n. (ND, RM, UC). Santa Barbara Co.: Mountain Drive, Santa Barbara, 21 Aug 1904, Abrams 4116 (DS, NY, POM); head of Canyon del Cojo, 5.5 mi NE of Point Conception, Santa Ynez Mountains, 8 Jun 1960, E.R. Blakley 3471 (CAS, RSA); mesa between Bates Canyon and Schoolhouse Canyon, S side of Cuyama Canyon, 18 May 1965, Chandler 2325 (SBBG); Blockman's Ranch, 13 Jun-3 Jul 1906, Eastwood 459 (CAS, GH, NY, US); head of Manzana River and White Ledge, San Rafael Mountains, 29 May 1959, Hardham 4691 (CAS, RSA); Middle Camuesa Camp, Camuesa Canyon, 7 Jun 1946, Mason 12824 (OKL, SD, UC); Camino Cielo near Santa Ynez Peak, 27 Jun 1955, Pollard s.n. (ARIZ, CAS); Arroyo Burro Trail, San Roque Canyon, Santa Ynez Mountains, 7 Jun 1952, Pollard s.n. (CAS, RM, WS); Sierra Madre Mountains, along Sierra Madre Road, $1.3 \mathrm{mi}$ NW of the road to McPherson Peak and $5.6 \mathrm{mi}$ SW of the Bates Canyon Road, 21 Jun 1987, Reveal \& Broome 6519 (ARIZ, ASU, BM, BRY, CAS, MARY, MICH, MO, NY, RM, RSA, TCD, US, WIS); La Cumbre Trail in Mission Canyon, Santa Barbara, 21 Jun 1944, C.F. Smith 977 (SBBG, UCSB); Santa Barbara, 1865, Torrey 433 (GH, MIN, NY, US). Unknown Co.: without location data, 1831, Coulter 576 (E, TCD); without location data, 1881, Parry s.n. (F, G, LE, NY, ORE, UC, US). Ventura Co.: Point Mugu, 8 Jul 1931, Abrams \& Wiggins 412 (DS); North Fork of Matilija Creek, $1 \mathrm{mi}$ above Wheeler Hot Springs, Topatopa Range, 17 Jun 1941, Constance 2842 (BKL, CAN, CAS, DS, F, GH, IDS, ILL, MICH, MIN, ND, NO, NY, ORE, POM, RM, SBBG, UC, UCSB, US, UTC, WS, WTU); Camarillo, 27 Apr 1926, M.E. Jones s.n. (POM); Santa Paula, 1887-1888, Parry s.n. (MO, NY); Dry Lakes Ridge, Matilija-Sespe divide, Los Padres National Forest, 29 Jun 1965, Pollard s.n. (CAS, NO, SBBG); Pratt Canyon Trail, Ventura River Basin, 15 Jun 1945, Pollard s.n. (CAS, MO, RSA, SBBG); flood plain of the Ventura River N of the Baldwin Road crossing, Ojai Valley, 26 Jun 1969, Pollard s.n. (DAO, OSC, SBBG); Casitas Pass, Jul 1875, Rothrock 168 (F, GH, PH, US). A total of 579 collections are known to us.

Nowhere in our revision of Chorizanthe is there a more profound difference of opinion than that expressed in our treatment of the C. staticoides (Greek statikos, causing to stand, and eidos, like or similar to, alluding to the similarity of this species to plants of the genus Statice in the Plumbaginaceae) complex compared to that presented by Goodman (1934). We recognize five species; he had seven, adding $C$. discolor and $C$. chrysacantha to the list. Additionally, he recognized a series of infraspecific entities but we can maintain only one of his varieties.

Chorizanthe staticoides is one of the more widely distributed species among the California endemics in the genus, and it is one of the most variable. The Douglas type represents the northern phase and was probably collected in the Santa Lucia Mountains of Monterey Co. That expression extends from that county southward to southern San Luis Obispo Co. In the Transverse Ranges are three more or less isolated populations extending from the Santa Ynez Mountains eastwardly to the the San Bernardino Mountains. There are also three ex- 
pressions, but none is restricted to any one of the isolated regions. The reddish stemmed one is the most common (or at least the most commonly collected). It is found throughout the three ranges: the Sierra Madre-Santa Ynez mountains of Santa Barbara and Ventura cos.; the Santa Monica Mountains of Ventura and Los Angeles cos.; and the San Gabriel-San Bernardino mountains of Los Angeles and western San Bernardino cos. The greenish stemmed one is found mainly in the Santa Monica and San Gabriel Mountains. It was distinguished by Nuttall (1848) as $C$. nudicaule who based the name on a Gambel collection from Santa Barbara. In the western population of Ventura and Santa Barbara cos., some plants tend to have their lower foliaceous bracts remain on the plant longer than elsewhere. The involucres of such plants are somewhat smaller and more corrugate than the norm as well. This phase Goodman (1934) distinguished as f. bracteata.

There is an expression infrequently found in the San Gabriel, San Bernardino and Santa Ana mountains of southern California that tends to be rather tall and long-leaved. It has been typically collected in areas that had recently burned and probably represents an elongated sun form. Such plants are soon lost as the shrubs recover and the more typical shade expression of Chorizanthe staticoides results.

All of these expressions fall into a single species, Chorizanthe statioides. The one expression that is arguably distinguishable is the coastal form that occurs along the immediate coast in Orange and San Diego cos. This plant was initially called C. discolor (Nuttall 1848), but named again as $C$. chrysacantha by Goodman (1934). The two type collections were gathered at the extreme ends of the coastal range. Goodman considered the $C$. discolor phase to be a plant found just slightly inland from the immediate coast, and to be a bit more upright and generally smaller flowered. Chorizanthe chrysacantha was defined as a plant found only along the immediate coast and characterized by its low, spreading stature and and longer flowers. The coastal expressions differ from the bulk of $C$. staticoides to the north and east in having longer awns. None of these features is consistent. The two coastal expressions now have disjunct ranges probably due to recent habitat destruction and neither is currently common in the few places still available for such plants to survive in southern California.

Munz $(1959,1974)$ recognized the Orange Co. population as Chorizanthe staticoides subsp. chrysacantha, treating the coastal San Diego Co. expression, C. discolor, as a synonym of the typical expression of $C$. staticoides. Even though there are two disjunct coastal phases, we believe the two are not taxonomically distinct and if it is to be recognized, it should be considered a single taxon. According to the International Code of Botanical Nomenclature (Greuter et al. 1988), the epithet chrysacantha is available at both the subspecies and variety ranks, but discolor would be the correct name at the species rank.

We reject the use of infraspecific entities within Chorizanthe staticoides, and specifically the recognition of the $C$. discolor-C. chrysacantha expression at any infraspecific rank simply because it is only a local, ecologically induced form whose morphological distinctiveness quickly breaks down once plants away from that ecological setting are examined. In fact, in the case of the Orange Co. population, one can find the $C$. chrysacantha expression on the immediate coast, the $C$. discolor expression on the foothills just east of the coast, and this rapidly dissolves into the typical $C$. staticoides form on the foothills of the Santa Ana Mountains just to the east of the coastal foothills. Thus, all three expressions can be found in the one disjunct population in western Orange Co. while on the Santa Ana Mountains themselves, one finds only typical $C$. staticoides. 
24. Chorizanthe leptotheca Goodman, Ann. Missouri Bot. Gard. 21: 61. 1934.-TYPE: dry hills between Ramona and Ballena, San Diego Co., California, 19 Jun 1903, Abrams 3777 (holotype: MO!; isotypes: BM, CHSC, DS, E, F, G, GH, K, MO, NEB, NY, ORE, PH, POM, UC, US, Z!).

Erect to spreading, thinly pubescent annual herbs 0.5-3 (3.5) dm high and 0.5-3 (5) dm across; leaves basal, oblong to oblong-ovate, the blades $0.5-2(3) \mathrm{cm}$ long, $3-5$ (7) $\mathrm{mm}$ wide, thinly pubescent on the upper surface, usually rather densely tomentose on the lower, obtuse to rounded apically, usually tapering to a pubescent petiole $1-3(4) \mathrm{cm}$ long; inflorescences cymose, mostly flat-topped and openly branched, reddish; bracts 2 , opposite, reduced and scalelike to occasionally foliaceous at the lowermost nodes and similar to the leaves only more reduced, 3-4 $\mathrm{mm}$ long, $2-3 \mathrm{~mm}$ wide, the foliaceous ones ovate and short petiolate, otherwise linear and acicular, these $1-3 \mathrm{~mm}$ long, 0.7-1 $\mathrm{mm}$ wide, often acerose, the awns straight, $0.5-1 \mathrm{~mm}$ long; involucres usually somewhat congested terminally with a solitary one at the node of the dichotomies, reddish, smooth, the tube cylindrical, 3-angled but 6-ribbed, 3-4 mm long, thinly pubescent with slender curly hairs, without a scarious margin, the teeth spreading, 0.7-1.5 mm long, the longer three with one longer and more erect than the others, these alternating with the three shorter and less prominent ones, the awns 0.5-1 mm long, uncinate; flowers long exserted, cylindric, $4.5-6 \mathrm{~mm}$ long, rose to red, infrequently with white lobes, pubescent without nearly the entire length of the midrib with the hairs not extending to the apex of the tepals, sessile or on pedicels $0.1-0.2 \mathrm{~mm}$ long, the tepals monomorphic or more frequently dimorphic, narrowly oblanceolate, with the outer tepals slightly broader and occasionally longer than the inner ones, the lobes rounded apically, united about two-thirds of their length; stamens 9, mostly included, the filaments $4-6 \mathrm{~mm}$ long, glabrous, reddish, the anthers 0.5-0.6 mm long, oval to oblong, pink to red; achenes brown, narrow, 3-4 mm long; $n=19$.

Sandy to gravelly places in the mountains of southern California from the foothills near the southern base of the San Bernardino Mountains southward along the eastern edge of the Santa Ana Mountains and through the San Jacinto and Santa Rosa mountains of Riverside Co. into the mountains of central San Diego Co. and extreme north-central Baja California Norte, México, along the border from Otay Mesa to the Tecate Mountains, from (1200) 2000-5200 (6000) ft elev, flowering from May-Aug.

Representative Specimens: MÉXICO. BAJA CALIFORnIA NORTE: NE slope at NW base of Cerro el Dieciseis, 11 km SSE of Tecate, 24 Jun 1979, Moran 27672 (ARIZ, CAS, MO, NY, RSA, SD); 11 km E of Tecate, 7 Jun 1980, Moran 28698 (ENCB, MICH, MSC, NY, RSA, SBBG, SD, TEX); without location data, 2 Jul 1884, Orcutt s.n. (BM, F, G, NY, WS); Tecate Mountains, 2 Jul 1884, Orcutt s.n. (CM, MEXU, NY); 15 mi E of Tecate on road to Mexicali, 30 Jun 1962, Wiggins \& Thomas 432 (DS). UNITED STATES: CALIFORNLA: Riverside Co: Temescal Canyon, benches of Indian Wash S of Interstate 15, 22 Apr 1986, Boyd 1758 (COLO, HSC, NY, TEX, UCR); Hurkey Creek, Hemet Valley, 3 Jul 1932, Clary 991 (ARIZ, JEPS); E side of Dripping Springs Campground between Aguanga and Temecula, 22 May 1980, Erter \& Strachan 3491 (MARY, UC); Fuller's Mills Mountain, Jul 1901, H.M. Hall 2255 (CAS, UC); MacMullen Trail, E slope of San Jacinto Mountains, 14 Jun 1922, Jaeger s.n. (DS, US); $10 \mathrm{mi}$ SW of Cahuilla, 21 May 1927, Munz 10879 (POM, SBBG); 3 mi E of Fairview Avenue in Valle Vista, 23 May 1988, Reveal 6864 (BRY, CAS, MARY, MO, OSC, RSA, WIS); San Jacinto Mountains, along the road toward Lake Hemet Campground on the N shore of Lake Hemet 27 Jun 1987, Reveal \& Broome 6611 (ARIZ, CAS, MARY, MICH, MO, NY, RM, RSA, TCD, US, WIS); San Jacinto Mountains, 1 Jul 1934, Stokes 311 (CAS, DS, G, K, MICH, UC, US, UTC, Z). San Bernardino Co.: San Timoteo Canyon, S of Redlands, 22 May 1948, Roos 3863 (COLO, UCR); hills near the sanitarium, near Loma Linda, 1 Apr 1926, E.S. Spalding s.n. (RSA). San Diego Co.: Witch Creek, Jun 1894, Alderson s.n. (DS, GH, UC); Descanso, Jun 1910, K Brandegee s.n. (DS, UC, US); Campo, 4 Jul 1884, Cleveland s.n. (F, RSA, SD); S end of Cuyamaca Ranch along California Highway 79, 10 Jun 1941, D. Dunn 1271 (ENCB, LA, NY, SMU); between Campo and Canyon City, 22 May 1941, Gander 9312 (RSA, SD, UC); 8 mi S of Cuyamaca on California Highway 79, 15 Jun 1969, Holmgren \& Jensen 3573 (NY, US, 
UTC); along California Highway 188, $1.5 \mathrm{mi} \mathrm{N}$ of Tecate, 21 May 1988, Reveal 6846 (BM, BRY, CAS, MARY, MO, OSC, RM, RSA, US, UTC, WIS); at the summit of Cameron Truck Road, 1.2 mi NE of Buckman Springs Road, 21 May 1988, Reveal 6854 (BM, BRY, CAS, MARY, MO, NY, OSC, RM, RSA, US, UTC, WIS); Pine Hills, along East Grade Road (County Road S-7), $3.4 \mathrm{mi}$ NW of California Highway 76 near Lake Henshaw, 28 Jun 1987, Reveal \& Broome 6623 (CAS, MARY, NY); Pine Valley, Corte Madera Ranch, 3 Jul 1980, van der Werff 4010 (LA, SD). A total of 93 collections are known to us.

Chorizanthe leptotheca (from Greek leptos, thin, and theke, box, alluding to the narrow involucre) is found to the east of $C$. staticoides and basically the ranges of the two species do not overlap. Chorizanthe leptotheca has a longer flower and a longer and narrower involucre. Also the involucres are not as densely clustered as they are in C. staticoides. The form of the species found in the southern part of its range is a rather stunted expression on the granitic sands in the chaparral. To the north, where the plant is still found mainly on granitic soils, it is taller and more open in the pine forests of the San Jacinto Mountains. The distinction between $C$. leptotheca and $C$. staticoides is sometimes difficult to make, not only in the herbarium but in the field as well. The fact is that it requires some experience to detect the subtle difference between "exserted" and "slightly exserted" flowers, and one must accept that the measurements are not always diagnostic because at the extremes of both species the measurements overlap.

The chromosome count of $n=19$ reported here was obtained by Reveal and is vouchered by Reveal 6846, 6854 and 6856.

We have continued to maintain Chorizanthe leptotheca as a valid species and distinct from C. staticoides because if it were submerged all of the other species of the subsect. Staticoides would have to be reduced in rank as well. What we have attempted to do is maintain the distinctive and consistent expressions, reducing those that are not morphologically recognizable throughout its geographic range.

\section{Chorizanthe xantii S. Wats.}

Erect to infrequently spreading, thinly pubescent annual herbs (0.3) $0.5-2.5$ (3) dm high and $0.5-3$ (5) dm across; leaves basal or nearly so, oblong or oblong-ovate to ovate, the blades 0.3-1 (1.5) cm long, 3-8 (10) mm wide, thinly pubescent above, densely tomentose below, obtuse to rounded apically, usually tapering to a pubescent petiole 1-2 (3) cm long; inflorescences cymose, mostly flat-topped and openly branched, reddish; bracts 2 , opposite, rarely more, usually foliaceous at the lower nodes and similar to the leaves only more reduced, the blades 3-8 $\mathrm{mm}$ long, 2-6 mm wide, oblong-ovate to ovate and short petiolate, reduced at the upper nodes and scalelike, 1-4 mm long, 0.5-1 mm wide, linear and acicular, often acerose, the awns straight, $0.5-1 \mathrm{~mm}$ long; involucres in open clusters with a solitary one at the node of the dichotomies, reddish, smooth, the tube cylindrical, 3-angled but 6-ribbed, 3-4.5 mm long, thinly to densely pubescent with slender curly hairs, without a scarious margin, the teeth spreading, 0.7-1.5 mm long, the longer three with one longer and more erect than the others, these alternating with the three shorter and less prominent ones, the awns $0.5-1 \mathrm{~mm}$ long, uncinate; flowers long exserted, cylindric, 4.5-6 mm long, rose to red, infrequently with white lobes, pubescent without nearly the entire lenght of the midrib with the hairs not extending to the apex of the tepals, on pedicels $0.2-0.4 \mathrm{~mm}$ long, the tepals monomorphic to slightly dimorphic, narrowly oblanceolate, occasionally with the outer tepals slightly broader and longer than the inner ones, the lobes rounded apically, united about two-thirds of their length; stamens 9, mostly included, the filaments 4-6 mm long, glabrous, reddish, the anthers 0.5-0.6 $\mathrm{mm}$ long, oblong, pink to red; achenes brown, narrow, 4-4.5 $\mathrm{mm}$ long. 
Sandy to gravelly or rocky places on valley floors, foothills and mountains in the inner Coast Ranges from western Merced, eastern Monterey and San Benito cos. south to the Transverse Ranges of northern Santa Barbara and Ventura cos., hence eastward along the northern foothills of the San Gabriel and San Bernardino mountains to extreme southwestern San Bernardino Co., and then northward through the Tehachapi Mountains to central and eastern Kern Co. onto the foothills of the Sierra Nevada to Madera Co., with disjunct populations in southern Mono Co. and at the eastern end of the San Bernardino Mountains southward onto the eastern slopes of the San Jacinto Mountains in Riverside Co., California, from (200) 1000-5000 ft elev, flowering from Apr-Jul.

\section{Key to the Varieties}

A. Involucres sparsely pubescent; western San Bernardino Co. north. 25a. var. xantii AA. Involucres densely pubescent; eastern end of San Bernardino Mountains south to San Jacinto Mountains.

Chorizanthe xantii is the eastern, more arid expression of the $C$. staticoides complex. It is found in the inner Coast Ranges and the southern Sierra Nevada southward onto the more arid northern slopes of the San Gabriel and San Bernardino mountains. To a degree, $C$. xantii is generally found at a lower elevation and on a drier site than the adjacent, more mesic $C$. staticoides in the areas where the two occur in overlapping regions. A morphological distinction between the two species is not always easy to make. This is particularly true of plants found in central Ventura Co., in the Tejon Pass area, and in the Soledad area of Los Angeles Co. In the Sespe area of northern Ventura Co., however, C. xantii can be found elevationally above $C$. staticoides. Here as elsewhere $C$. xantii is a more erect and generally brighter pink plant comparted to the more spreading and duller C. staticoides.

We recognize two varieties in Chorizanthe xantii, following Goodman (1934).

25a. Chorizanthe xantii S. Wats., Proc. Amer. Acad. Arts 12: 272. 1877, var. xantii.-TYPE: near Ft. Tejon, Kern Co., California, 1858-1859, Xantus s.n. (holotype: GH! isotypes: NY, US!).

Involucres thinly pubescent; $n=19,21$ (Hardham 1989).

Range of the species except for that portion from the eastern end of the San Bernardino Mountains south to the San Jacinto Mountains.

Representative Specimens: UNITED STATES. CALIFORnIA: Fresno Co.: Kings River Canyon at Piedra, Barneby \& Howell 11421 (CAS); Los Gatos Creek Road W of Coalinga, 29 May 1965, Hardham 12601 (RSA); Alcalde Hills, 24 Mar 1986, Janeway \& Janeway 1407 (CHSC). Kern Co.: Cottonwood Creek, Greenhorn Mountains, 23 Apr 1932, Benson 3351 (DS, ND, UC, US); near Caliente, 24 Jun 1891, Coville \& Funston 1100 (DS, K, US); Lebec, 9 Jun 1942, Degener \& Peiler 16038 (CAS, MIN, NY, PH, RM); lower end of Cuddy Canyon, Mt. Pinos region, 16 Jun 1896, Dudley \& Lamb 4556 (DS, F, MARY, POM, UC, WTU); near Edison, 27 Apr 1937, Eastwood \& Howell 4003 (CAS, F, MICH, NY); McKittrick, 29 Apr 1905, Heller 7797 (BKL, DS, E, F, G, GH, ISC, L, MO, MSC, NY, PH, UC, US); 2.5 mi SE of Keene, Tehachapi Mountains, 25 Jun 1957, J. T. Howell 32765 (CAS, RSA, SMU); NE of Lake Isabella, 21 May 1962, J. T. Howell 37173 (CAS, DAV, RENO); along California Highway 155, $6.1 \mathrm{mi}$ W of Woody, 18 May 1983, McNeal 2811 (BRY, CPH, NY, OSC, UT); 4.9 mi S of Havilah Ranger Station on road from Caliente to Bodfish, 5 Jul 1956, Munz \& Balls 21878 (RM, RSA, SD, UC, UT); Tehachapi, Jun 1883, Parry s.n. (F, G, GH, K, MIN, VT); Erskine Creek, Apr-Sep 1897, Purpus 5027 (E, GH, K, MO, UC, US, Z); 2 mi SE of Keene, 25 Jun 1957, Rose 57113 (ARIZ, B, BRY, COLO, DAO, DS, G, GH, MICH, MIN, NY, RSA, SMU, UC, US, W); Kernville, 20 May 1962, Rose 62032 (CAS, COLO, DAV, ENCB, OBI, RM, TEX); NW of mouth of Adobe Canyon, Poso Hills, 19 Apr 1962, Twisselmann 7015 (CAS, RSA, SBBG); Pleyto Canyon, 1.3 mi below Neasons Flat, 3 Jun 1963, Twisselmann 8307 (CAS, RSA, SBBG). Kings Co.: Kettleman Hills, near Avenal, 1 May 1938, Hoover 3313 (UC, US). Los Angeles Co.: San Andreas Rift Valley, 0.5 mi WNW of Hughes Lake, 21 Jul 1958, Alava 2248 (DAO, LE, W); along California Highway 138, 15 mi SE of Palmdale, 27 Apr 1968, Fuchs 
13 (UNLV); Upper Shake Campground, 3 mi W of Lake Hughes, 11 Jul 1963, Thorne 32779 (BM, DAO, G, RSA); along Soledad Canyon Road, 2 mi W of Soledad Station, San Gabriel Mountains, 17 Jun 1971, Thorne \& Tilforth 39892 (E, RSA, UC). Madera Co.: San Joaquin Experiment Station, 10 Jun 1937, Biswell s.n. (NEB). Merced Co.: Piedra Azul Canyon, SW of Los Banos, 4 May 1940, Hoover 4376 (DS, K, LL, MICH, MIN, NY, RM, SMU, UC, US, WS, WTU); 2 mi NE of Ortijalta Peak, San Carlos Range, 5 Jun 1938, Lyon 1265 (MO, OKL, RM, UC, WTU). Mono Co.: near Benton Station along U.S. Highway 6, near foot of fan of Montgomery Creek, 31 May 1935, Robinson \& Lindner 20 (RSA). Monterey Co.: Lowe's Canyon, 15 mi NE of San Miguel, 15 May 1958, Hardham 3322 (CAS, DAO); Hidden Valley Ranch, Slack Canyon, along the trail to Serrate Sandstone Ridge, 28 May 1965, Hardham 12627 (CAS, RSA); near summit of Mustang Grade E of San Lorenzo Creek, 22 Jun 1963, J. T. Howell 39513 (CAS, DAO, ENCB). San Benito Co.: Bettys Ranch, Lorenzo Canyon, along the road to Hernandez Valley, 1925, Bettys s.n. (DAO, JEPS, MO, NY, WIS). San Bernardino Co.: Cajon Canyon, near Rock Candy Mouptain, San Gabriel Mountains, along California Highway 138, 29 May 1966, Holmgren \& Reveal 2606 (CAS, NY, US, UTC); Lone Pine Canyon, San Gabriel Mountains, 30 May 1921, Jepson 2419 (JEPS, NO, POM, RSA); Santa Ana River bottom, San Bernardino Valley, 15-23 May 1913, Jepson 5565 (JEPS, OKL); Crofton, 1876, Lemmon 94 (NY); Lone Pine Canyon, 17 Jun 1921, Munz 4654 (POM); near San Bernardino, 11 May 1901, Parish 4771 (DS, NY, US); San Bernardino, May 1882, Parish \& Parish 638 (BR, LE, MPU); without location data, 1876, Parry \& Lemmon 368 (BM, CAS, MIN, MO, PH, US); hills bordering the Mojave Desert, 25 May 1882, Pringle s.n. (CAN, E, F, G, GH, LE, MPU, NY, PENN, PH, US, VT, WU). San Luis Obispo Co.: 20 mi W of New Cuyama along California Highway 166, 12 May 1962, Breedlove 2776 (DS, UCSB); Cottonwood Pass, 8 Apr 1961, Hardham 6794 (CAS, RSA, SBBG, UCSB); San Juan River on the Pozo-Simmler Road, 4 Jun 1949, Hoover 7751 (CAS, DAO, DS, OBI, UC); N end of Elkhorn Plain, Temblor Range, 4 Jun 1967, Hoover 10608 (CAS, OBI, UC); along California Highway 58, 2.4 mi E of San Juan Creek between La Panza and Carrisa Plains, 26 May 1988, Reveal 6908 (BRY, CAS, MARY, MO, RSA, WIS); Caliente Range, Padrones Spring Canyon, 3 May 1957, Twisselmann 3463 (CAS). Santa Barbara Co.: Santa Barbara Canyon near its junction with the Cuyama River, 20 May 1960, E.R. Blakley 3462 (CAS, RSA, SBBG); W of Branch Canyon, S of the Cuyama Oil Fields, 24 May 1988, Reveal 6879 (BRY, CAS, MARY, MO, NY, OSC, RSA, UTC, WIS); S end of South Cuyama Oil Field, 24 May 1988, Reveal 6885 (BRY, CAS, MARY, MO, NY, RSA, WIS); along the Ballinger Canyon Road, $0.5 \mathrm{mi}$ E of California Highway 33, 24 May 1988, Reveal 6890 (CAS, MARY, MO, RSA). Tulare Co.: Three Rivers, 24 Jul 1905, K. Brandegee s.n. (UC); Kern River Canyon at Gold Lodge Creek, 23 Jun 1970, Howell \& True 46607 (CAS); near Black Park, Jul 1937, Winblad s.n. (CAS). Unknown Co.: Mojave Desert, 1884, Curran s.n. (PH, RSA, UC); without location data, 1883, Parry s.n. (B, F, G, LE, NEB, NY, ORE, UC, US); without location data, 1876, Parry \& Lemmon 368 (F, G, MIN, NEB, NY, VT). Ventura Co.: Ballinger Canyon, 0.5 mi E of California Highway 33, 7 May 1965, Chandlet 2165a (SBBG); 5 mi E of U.S. Highway 399 along road connecting U.S. Highway 399 with U.S. Highway 99, 4 Jun 1959, Haller 1420 (UCSB); Apache Creek, upper Cuyama River Valley, 13 May 1960, Hardham 5684 (UC); along the Lockwood Valley Road, 11.7 mi ENE of Ozena, 24 Jun 1987, Reveal \& Broome 6565 (ARIZ, CAS, MARY, MO, NY, RSA, TCD, WIS); 3 mi E of the Ventacopa Highway, Dry Canyon, 14 Jun 1956, Twisselmann 2998 (CAS). A total of 235 collections are known to us.

The distribution of Chorizanthe xantii var. xantii (Louis John Xantus de Vasey, 1825-1894, an Hungarian naturalist who collected in California and México while an employee in various capacities with the U.S. Government) as presented here has been sanitized to reflect what we consider to be more realistic than what might be construed from available herbarium specimens. Specifically we have deleted a collection supposedly gathered in Tempe, Maricopa Co., Arizona, in 1892 (Ramone \& Blaschka s.n., GH!) and a San Diego Co., California, collection found near the Mexican boundary (Parish 638, G) in June of 1880 . The numerous specimens from near San Bernardino and the Crafton Hills in San Bernardino Co. may be suspect as the collectors of such specimens were not always exact with their label data.

25b. Chorizanthe xantii S. Wats. var. leucotheca Goodman, Ann, Missouri Bot. Gard. 21: 60. 1934. Chorizanthe xantii S. Wats. subsp. leucotheca (Goodman) Munz, Fl. S. Calif. 676. 1974. - TYPE: Whitewater, Riverside Co., California, 11 May 1903, M.E. Jones s.n. (holotype: POM!; isotype: UC!).

Involucres densely white pubescent. 
Sandy to gravelly places in washes and along the lower foothills of the eastern San Bernardino Mountains southward onto the eastern slopes of the San Jacinto Mountains in Riverside Co., California, from (200) 1300-4000 ft elev, flowering from Apr-Jun.

Representative Specimens: UNITED STATES. CALFORnIA: Riverside Co.: Palm Cañon, Palm Springs, $30 \mathrm{Apr}$ 1913, Eastwood 3100 (CAS); Mission Creek Wash, 15 Apr 1926, Jaeger s.n. (POM); San Gorgonio Pass, 25 May 1914, Jepson 6065 (JEPS); E side of Mt. San Jacinto, San Jacinto Mountains, 22 May 1981, Lyman s.n. (UCR); Palms to Pines Highway, N slope of the Santa Rosa Mountains, 29 May 1937, Munz s.n. (POM); mesas near Palm Springs, 19 Apr 1907, Parish 6168 (DS); San Gorgonio, 1876, Parry \& Lemmon 368b (GH, K, NY); Whitewater Canyon, N of hatchery, 5 mi N of Interstate 10, 4 May 1986, Pitzer 199 (UCR); Whitewater, 8 May 1948, Roos 3827 (COLO, TEX, UCR); along Whitewater River, $3.2 \mathrm{mi} \mathrm{N}$ of Whitewater P.O. and Interstate 10, 28 May 1980, Thorne \& Tilforth 54223 (ARIZ, BRY, HSC, MARY, NY, RSA, TEX); Snow Creek Canyon, 1 mi below the hatchery, 25 May 1932, Wolf 3677 (DS, RSA, SD, UC, US, WTU). San Bernardino Co.: head of Dry Morongo Creek, Morongo Valley, 1 Jun 1941, Alexander \& Kellogg 2270 (BKL, DS, F, GH, ISC, K, MICH, MO, NY, ORE, POM, RM, SBBG, UC, US, UTC, WS, WTU); Morongo Valley, 11 Apr 1937, Haines \& Erickson s.n. (LA); 19 mi NE of Banning, $3 \mathrm{mi} \mathrm{N}$ of Morongo Valley, $2.3 \mathrm{mi}$ NW of California Highway 62 on the road to Big Morongo Canyon, 29 May 1971, Henrickson 5558 (UNLV); upper end of Desert Wash Trail, Morongo Valley, 21 Apr 1985, D.A. Hoover 372 (UCR). A total of 35 collections are known to us.

The var. leucotheca (from the Greek leukos, white, and theke, box, alluding to the densely white tomentose involucres) is maintained as a distinct entity primarily on the basis of its unique geographic range, being well removed from var. xantii, and the morphological consistency by which the taxon can be distinguished. The densely pubescent involucre which characterizes var. leucotheca is hinted at in scattered individuals of immature specimens of var. xantii and we suggest this is the result of neoteny. Takhtajan (1976) defines the term as meaning "an extension of early developmental phases into maturity." If this is so, it can be argued that the var. leucotheca is the result of a late Pleistocene isolation when the species was further south than at present. With the start of the Holocene and the northward migration of the species, a series of populations were isolated and survived the extreme warmth of the Hypsithermal on the edge of the Sonoran Desert. While the var. xantii continued northward onto the rapidly forming Mojave Desert and into the southern part of the Central Valley and south Coast Ranges where it reaches but does not cross the Salinas River, the southern expression was evolving into a rapidly maturing distinct variety that still maintained some of its juvenile characters.

26. Chorizanthe breweri S. Wats., Proc. Amer. Acad. Arts 12: 270. 1877.- TYPE: dry rocky hillsides, San Luis Obispo, San Luis Obispo Co., California, Apr 1861, Brewer 456 (holotype: GH!; isotypes: $\mathrm{K}, \mathrm{MO}, \mathrm{UC}$, US!).

Ascending to decumbent, thinly pubescent annual herbs (0.3) 0.5-1.5 (2) dm high and 1-5 (7) dm across; leaves basal, spatulate to ovate, the blades $0.5-2 \mathrm{~cm}$ long, 3-12 (15) $\mathrm{mm}$ wide, thinly pubescent on both surfaces but sometimes more so to densely tomentose below, obtuse to rounded apically, usually tapering to a pubescent petiole $1-3 \mathrm{~cm}$ long; inflorescences cymose, mostly flat-topped, open to rather densely branched, reddish; bracts 2, opposite, usually foliaceous at the lower nodes and similar to the leaves only more reduced, the blades 3-8 $\mathrm{mm}$ long, 2-6 $\mathrm{mm}$ wide, oblong to ovate and short petiolate, reduced at the upper nodes and scalelike, $1-5 \mathrm{~mm}$ long, $0.5-1 \mathrm{~mm}$ wide, linear and acicular, often acerose, the awns straight, 0.5-1 mm long; involucres in open terminal clusters with a solitary one at the node of the dichotomies, reddish, corrugate, the tube cylindrical, 3-angled but 6-ribbed, $2.5-3 \mathrm{~mm}$ long, thinly pubescent with slender curly hairs, without a scarious margin, the teeth spreading, 0.4-1.2 $\mathrm{mm}$ long, the longer three with one longer and more erect than the others, these 
alternating with the three shorter and less prominent ones, the awns 0.3-0.6 mm long, uncinate; flowers slightly exserted, cylindric, $3-3.5 \mathrm{~mm}$ long, white to rose or red, usually with white lobes, pubescent without along the upper half of the midrib with the hairs not extending to the apex of the tepals, on pedicels $0.4-0.5 \mathrm{~mm}$ long, the tepals monomorphic to slightly dimorphic, narrowly oblong to obovate, with the outer tepals usually slightly broader and longer than the inner ones, the lobes rounded apically, united about half their length; stamens 9 , mostly included, the filaments $2.5-3 \mathrm{~mm}$ long, glabrous, reddish, the anthers $0.4-0.5 \mathrm{~mm}$ long, oblong, pink to red; achenes brown, narrow, 2.5-3 mm long; $n=19$ (Hardham 1989).

Gravelly ar rocky places on serpentine outcrops in the coastal ranges of San Luis Obispo Co., California, from 200-2500 ft elev; flowering from (March) Apr-Jul.

Representative Specimens: UNITED STATES. CALIFORNIA: San Luis Obispo Co: Chorro, May 1909, K. Brandegee s.n. (UC, US); Atascadero Ranch, 1 May 1861, Brewer 894 (GH, ISC, K, MO, US); San Carpojoro, Jun 1912, Condit s.n. (UC); Pettitts, near San Luis Obispo, 19 May 1928, Eastwood 15167 (CAS, GH, K); hills NE of San Luis Obispo, 7 May 1936, Eastwood \& Howell 2247 (CAS, F, GH, NY, US); Cerro Alta, Santa Lucia Range, 13 May 1958, Hardham 3289 (CAS); Steiner Creek, 20 Jun 1958, Hardham 3716 (RSA, SBBG); Cuesta Cypress Forest, 3 Jun 1960, Hardham 5989 (CAS, DAO, RSA, SBBG, UC); Reservoir Canyon, 15 Jun 1946, Hoover 6144 (CAS, DS, OBI, OKL); "Poly Canyon," Santa Lucia Range, 14 May 1953, Hoover 8294 (BRY, CAS, ILL, OBI, OKL, RM, UC, UTC, WIS, WS, WTU); East Fork of Corral de Piedra Creek, Santa Lucia Range, 14 May 1965, Hoover 9359 (CAS, DAO, OBI, RSA); 1 mi SW of California Highway 227 on Price Canyon Road, 21 Mar 1977, Imper 82 (OBI); San Luis Obispo, 6 May 1882, M.E. Jones 3234 (BM, BR, CAS, DS, ILL, LE, MIN, MSC, NY, POM, RM, UC, US, UTC); Eagle Ranch, SW slope of Eagle Peak, 29 May 1979, Krantz s.n. (UCR); Santa Lucia Range, along the road to Cerro Alto, $0.7 \mathrm{mi}$ NW of U.S. Highway 101 at Cuesta Summit, 17 Jun 1987, Reveal \& Broome 6472 (ARIZ, CAS, MARY, MO, NY, RSA); NE of San Luis Obispo, 7 May 1936, Rose 36236 (B, G, MO, RM, UC, VT, W); NE side of Laguna Lake Park, 7 May 1982, Smeltzer \& Turnquist 109 (OBI); near the coast, 30 May 1892, Summers s.n. (CAS, K); $1.3 \mathrm{mi} \mathrm{N}$ of San Luis Obispo and $4 \mathrm{mi}$ E of U.S. Highway 101, 18 Apr 1947, Vestal \& Vestal s.n. (DS, WTU). A total of 44 collections are known to us.

Chorizanthe breweri (William Henry Brewer, 1828-1910, geologist and botanical collector for the Whitney Survey of California, 1860-1864) is restricted to serpentine outcrops mainly in the southern Santa Lucia Mountains of San Luis Obispo Co. An occasional specimen of $C$. xantii and $C$. staticoides can be found on serpentine, but it is not the norm. We suspect that C. breweri evolved from typical $C$. staticoides, differentiating out on serpentine outcrops. The two species are readily distinguishable even when they occur on nearly adjacent sites, as they do east of San Luis Obispo (Hardham 5947, CAS); as yet we have not found any sympatric populations.

27. Chorizanthe wheeleri S. Wats., Proc. Amer. Acad. Arts 12: 272. 1877.-TYPE: Santa Barbara [actually Santa Cruz Island], Santa Barbara Co., California, Jul 1875, Rothrock 62 (holotype: GH!; isotypes: F, ISC, LA, US!).

Chorizanthe insularis R. Hoffmann, Bull. S. Calif. Acad. Sci. 31: 56. 1932.-TYPE: $0.5 \mathrm{mi}$ NE of the main ranch, Santa Cruz Island, Santa Barbara Co., California, 12 Apr 1931, Hoffmann s.n. (holotype: SBBG!; isotypes: CAS, DS, F, G, GH, JEPS, LA, MO, NY, POM, UC, US!).

Erect to spreading, thinly pubescent annual herbs $0.5-2$ (2.5) dm high and 1-2 dm across; leaves basal, elliptic to oblong, the blades $0.5-2 \mathrm{~cm}$ long, 2-6 mm wide, thinly pubescent above, tomentose below, obtuse to rounded apically, usually tapering to a pubescent petiole $0.5-3$ $\mathrm{cm}$ long; inflorescences cymose, mostly flat-topped and openly branched, reddish; bracts 2 , opposite, usually foliaceous at the lower nodes and similar to the leaves only more reduced, the blades 5-12 mm long, 2-4 $\mathrm{mm}$ wide, oblong and short petiolate, reduced at the upper 
nodes and scalelike, $1-5 \mathrm{~mm}$ long, $0.5-1 \mathrm{~mm}$ wide, linear and acicular, often acerose, the awns straight, $0.5-1 \mathrm{~mm}$ long; involucres in rather dense terminal clusters, with a solitary one at the node of the dichotomies, reddish, corrugate, the tube cylindrical, 3-angled but 6-ribbed, 2-2.5 mm long, thinly pubescent with stoutish, recurved hairs, without a scarious margin, the teeth spreading, 0.3-0.8 (1) $\mathrm{mm}$ long, the longer three with one longer and more erect than the others, these alternating with the three shorter and less prominent ones, the awns $0.3-0.5$ $\mathrm{mm}$ long, uncinate; flowers exserted, cylindric, 2.5-3 mm long, white or more commonly rose or red with white lobes, glabrous except for a few scattered hairs about midlength along the midrib with the hairs not extending to the apex of the tepals, on pedicels $0.3-0.4 \mathrm{~mm}$ long, the tepals monomorphic to slightly dimorphic, oblong, with the outer tepals usually slightly broader and longer than the inner ones, the lobes rounded apically, united about half their length; stamens 6 , included, the filaments $1.5-2 \mathrm{~mm}$ long, glabrous, whitish, the anthers $0.3-0.4$ $\mathrm{mm}$ long, oblong, pink to red; achenes brown, narrow, 2.5-3 mm long.

Gravelly to rocky places on Santa Cruz and Santa Rosa islands, Santa Barbara Co., California, from 20-1300 (1800) ft elev; flowering from Apr-Jun.

Representative Specimens: UNTTED STATES. CALIFORNIA: Santa Barbara Co.: Santa Cruz Island, near Pelican Bay, 26 Apr 1930, Abrams \& Wiggins 66 (CAS, DS, F, GH, UC); Santa Cruz Island, above swimming hole, 16 Oct 1958, Balls \& Blakley 23742 (RSA, UC); top of ridge between Coches Prietos Canyon and Alberts Anchorage, Santa Cruz Island, 29 Apr 1960, E.R. Blakley 3307 (RSA, SBBG); Santa Cruz Island, 1 mi S of Prisoners Harbor, 15 May 1962, Breedlove 2812 (DS, RSA, UCSB); Pelican Bay, Santa Cruz Island, 6 Jun 1930, Clokey 4907 (ASU, GH, ILL, MARY, ND, NY, OKL, PENN, POM, UC); Santa Rosa Island, Elder Creek, 17 Apr 1929, Hoffmann s.n. (CAS, SBBG); Santa Rosa Island, between Ranch and Torrey Pines, 8 Apr 1930, Hoffmann s.n. (SBBG); Santa Cruz Island, Cochie Canyon, 12 Apr 1931, J. T. Howell 6300 (CAS, RSA); N of the Caire ranch house, Santa Cruz Island, 27 May 1927, Jepson 12075 (JEPS, VT, WIS); Pelican Bay, Santa Cruz Island, 22 Apr 1932, McMinn s.n. (UC, UTC, WS); Lady's Harbor, Santa Cruz Island, 10 Apr 1930, Munz \& Crow 11847 (GH, POM); Cañada del Puerto, Santa Cruz Island, 13 Jul 1964, Philbrick B64288 (SBBG); Cherry Canyon, 1 mi SE of Vail Ranch headquarters, Santa Rosa Island, 14 May 1965, Philbrick \& Broder B65984 (SBBG, UCSB); Cañada Islay, S side of Central Valley, $1 \mathrm{mi}$ W of Stanton Ranch, Santa Cruz Island, 16 Jun 1964, Philbrick et al. B6423 (SBBG, UCSB); Santa Cruz Island, Portezuelo Grade, 26 Apr 1960, Raven \& Smith 15198 (CAS, DAO, RSA, SBBG, TEX); North Ridge, N of the Biological Station in Central Valley, Santa Cruz Island, 23 Apr 1979, Thorne et al. 52461 (MARY, $\mathrm{MICH}, \mathrm{RSA})$. A total of 65 collections are known to us.

As here defined, Chorizanthe wheeleri (George Montague Wheeler, 1842-1905, explorer and topographic engineer with the U.S. Geographical Explorations and Geological Surveys West of the One Hundredth Meridian) is restricted to the off-shore islands of Santa Cruz and Santa Rosa. It was once thought that Rothrock's type came from the mainland at Santa Barbara but as he visited Santa Cruz Island, he likely found the species there instead (Steve Junak, per. comm.).

The description of Chorizanthe insularis by Hoffmann (1932) was largely due to his failure to realize that the Rothrock type came from the islands. Goodman (1934) reduced his species to synonymy under $C$. wheeleri stating that the two did not differ but still regarded the original type to have been collected at Santa Barbara. To support this conclusion, Goodman cited a 1929 collection from the city (Hoffmann s.n., CAS). We suspect this collection is mislabelled and a duplicate of the Santa Rosa Island collection he made in April we have cited above. We should note that Hoffmann's type was dated 1932 instead of 1931 . Based on a note on an isotype written by J. T. Howell, his collection (Howell 6300) was made at the same time and place that Hoffmann gathered the type.

Chorizanthe wheeleri probably evolved from that expression of $C$. staticoides found in the Santa Ynez Mountains that Goodman (1934) described as f. bracteata. The two are difficult to distinguish without determining the stamen numbers (six in $C$. wheeleri, nine in $C$. 
staticoides) or without noting the type of hair found on the involucre. On the island species the few hairs present are stout and curled while those of the mainland species are more numerous and much more slender.

A specimen supposedly collected at Carmello, near Monterey (Cessac s.n., MICH), in 1879 is most certainly Chorizanthe wheeleri. We assume the sheet is mislabelled.

IVA(8). Chorizanthe Benth. ex R. Br. subsect. Flavae Goodman, Ann. Missouri Bot. Gard. 21: 81. 1934.- TYPE: Chorizanthe flava Brandegee, according to Art. 22.4 of the ICBN.

Plants prostrate or spreading to erect; leaves basal, oblanceolate to obovate, spatulate or elliptic; bracts linear and scalelike; involucres cylindrical or narrowly campanulate to campanulate, thinly to densely pubescent, without a scarious margin but with a thin hyaline margin between the teeth, the teeth of two markedly different sizes, the larger ones prominent and awned, the smaller often obsolete and occasionally awnless; flowers yellow or bicolored with the tube yellow to yellowish-white and the lobes white to pink or rose to red, exserted from the involucre, glabrous or slightly pubescent without, the tepals entire or fimbriate to laciniate, the whorls slightly dimorphic; stamens 9 , attached at the base of the tepals.

A taxon of six species mainly of Baja California, México, ranging northward into southern California as far north as Riverside Co., from 200-5500 ft elev, flowering from (Dec) Feb-Jun (Jul).

\section{Key to the Species}

A. Plant sparsely pubescent, not glandular, tepals entire or if fimbriate then involucres campanulate.

B. Flowers bicolored, only the tube yellow; tepals entire or fimbriate.

C. Tepals entire, thinly pubescent.

D. Flowers 4-5 mm long; filaments $2-2.5 \mathrm{~mm}$ long; achenes $2.5-3 \mathrm{~mm}$ long; east of the coast in the San Quintín area south to east of El Rosario. 28. C. turbinata

DD. Flowers (6) 7-9 mm long; filaments $4-6 \mathrm{~mm}$ long; achenes $3.5-4 \mathrm{~mm}$ long; Sierra San Borja.

29. C. mutabilis

CC. Tepals fimbriate or laciniate, glabrous.

D. Tepal lobes pink to rose, oblong, fimbriate; flowers $4.5-6 \mathrm{~mm}$ long; filaments $2-3 \mathrm{~mm}$ long; involucral tube 3-4 mm long, central Baja California Norte between Cataviñá and Laguna Chapala. 30. C. rosulenta

DD. Tepal lobes white, broadly oblong to obovate, laciniate; flowers 4-6 (9) $\mathrm{mm}$ long; filaments 3-4 mm long; involucral tube 4-5 mm long; central Baja California Norte from near Laguna Chapala south to Desierto de Vizcaino in northwestern Baja California Sur. 31. C. pulchella

BB. Flowers yellow throughout, 4-6 mm long, glabrous; tepals entire; involucral tube $3-4.5 \mathrm{~mm}$ long, the smaller teeth awnless; central Baja California in the El Arco area. 32. C. flava

AA. Plants minutely glandular and thinly pubescent; tepals fimbriate or laciniate, rose to red at maturity, glabrous except for a few scattered hairs; flowers 6-9 (10) mm long; involucres cylindric, the tube 4-6 (7) mm long, sparsely to densely pubescent; southern California from Riverside Co. southward in northern Baja California Norte to Santa Cecilia. 33. C. fimbriata

The subsect. Flavae (from the Latin flavus, yellow, as to the flower color of the type) is composed of three species complexes that might conceivably be distinguished as additional subsections. Chorizanthe turbinata and $C$. mutabilis have entire, thinly pubescent tepals, while $C$. pulchella and $C$. rosulenta have glabrous, fimbriate or laciniate tepals. Based on our evaluation of characters, $C$. flava falls in with the latter two species even though its tepals are entire. The third group consists only of $C$. fimbriata. This species is both glandular as well as thinly pubescent. The tepals are fimbriate to laciniate and are glabrous except for a few scattered hairs. Except for $C$. mutabilis and $C$. pulchella, none of these species have overlapping ranges, and even in the exception just noted the species are found on different soil or microhabitats. 
28. Chorizanthe turbinata Wiggins, Contr. Dudley Herb. 3: 67. 1940.-TYPE: dry slopes along Socorro Wash, between San Quintín and El Rosario, Baja California Norte, México, 19 Apr 1931, Wiggins 5208 (holotype: DS!; isotypes: CAS, F, GH, LA, MICH, NY, POM, RM, UC, US, UTC!).

Spreading to erect, sparsely pubescent annual herbs 0.3-0.8 (1) dm high and 0.5-4.5 dm across; leaves basal, oblanceolate to narrowly spatulate, the blades $1-3 \mathrm{~cm}$ long, 3-8 $\mathrm{mm}$ wide, thinly pubescent on both surface, obtuse to rounded apically, tapering to a pubescent petiole $0.5-2 \mathrm{~cm}$ long; inflorescences cymose, the involucres in small open clusters $0.3-1 \mathrm{~cm}$ across, greenish or reddish; bracts 2, opposite, 2-5 mm long, 1-1.5 (2) $\mathrm{mm}$ wide, linear and acicular, often acerose, the awns straight, 1-2 mm long; involucres narrowly campanulate, 3-angled but 6-ribbed, green to rose or red, corrugate, the tube $2.5-4 \mathrm{~mm}$ long, thinly pubescent with spreading hairs mainly on the ridges, with a thin hyaline margin between the teeth, the teeth of two markedly distinct sizes, the longer three prominent and thickened toward the base, 2.5-6 mm long, divergent, with a straight awn 1-2.5 mm long, the alternating smaller teeth 0.3-0.5 mm long, divergent, the awns lacking or $0.3-0.5 \mathrm{~mm}$ long, straight; flowers exserted from the involucre, cylindric, $4-5 \mathrm{~mm}$ long, bicolored, the tube yellow, the lobes white to rose, thinly pubescent without nearly the entire length of the midrib with the hairs not extending beyond the apex of the tepals, on pedicels $0.2-0.4 \mathrm{~mm}$ long, the tepals slightly dimorphic, narrowly oblong, entire, the inner ones shorter and narrower, united about two-thirds of their length; stamens 9 , included, the filaments $2-2.5 \mathrm{~mm}$ long, white, glabrous, the anthers 0.5-0.6 mm long, oblong, yellowish; achenes brown, narrow, 2.5-3 mm long; $n=20$.

Local and uncommon in sandy to gravelly soil on the foothills and mesas just east of the ocean in the San Quintín area south to east of El Rosario, Baja California Norte, México, from $500-1600 \mathrm{ft}$ elev, flowering from (Jan) Apr-Jun.

Specimens Examined: MÉXICO. Baja CaLfornia Norte: 18 mi E of El Rosario, 12 Apr 1952, Gentry \& Fox 11695 (B, MICH); just N of Arroyo Socorro, 8 mi from the mouth, 15 Jan 1973, Moran 19369 (ARIZ, ASU, CAS, GH, LL, MO, RSA, SD, US, W); 3.6 mi W of El Ciprés, 16 Jan 1973, Moran 19385 (NY, SD, UC); 7 mi NE of Las Escobas, 21 Apr 1975, Moran 21861 (ARIZ, DAV, ENCB, MICH, RSA, SD); 6 mi NE of Las Escobas, 30 May 1975, Moran 22091 (SD); N slope above Arroyo de la Escopeta, 3 Jun 1975, Moran 22373 (CAS, SD); N slope of Cañada Pabellon, 10 May 1978, Moran 25872 (ARIZ, MO, MSC, RSA, SD); on a low mesa S of the mouth of Arroyo Socorro, 1.3 mi E of México Highway 1, 20 May 1988, Reveal 6825 (CAS, MARY); Cañada las Palomas, $3.4 \mathrm{mi}$ E of México Highway 1, on the mesa above Arroyo El Socorro, 24 Mar 1988, Reveal et al. 6751 (CAS, MARY, MO, NY, RM, RSA, US, WIS).

The geographic range of Chorizanthe turbinata (from the Latin turbinatus, top-shaped, alluding to the shape of the involucre) has not been greatly expanded since Wiggins (1940) described the species. This species seems to represent the next logical, evolutionary step from the kind of plants found in the subsect. Staticoideae. The differences are mainly in the enlarged involucre and the bicolored flowers of $C$. turbinat $a$ and the remaining species of the subsect. Flavae. In this species, as in the majority of the others, the narrow involucral tube expands abruptly apically into three thickened and divergent teeth terminated by long, straight awns, and three, highly reduced teeth that are either awnless or terminated with minute awns. The flowers have a yellow tube with initially white but soon (and typically) rose colored lobes. Like the members of subsect. Staticoideae, the tepals in C. turbinata and C. mutabilis are thinly pubescent along the midrib nearly the entire length of the tepal. 
Reveal determined the chromosome number of this species to be $n=20$; his voucher is Reveal et al. 6751.

29. Chorizanthe mutabilis Brandegee, Proc. Calif. Acad. Sci. II, 2: 203. 1889.-TYPE: San Enrique, Baja California Norte, México, 2 May 1889, Brandegee s.n. (holotype: UC!; isotypes: CAS, DS, F, GH, L, MO, NESH, NMC, NY, PH, POM, US!).

Prostrate to spreading, sparsely pubescent annual herbs 0.3-0.8 (1) dm high and 0.5-5 (6) $\mathrm{dm}$ across; leaves basal, oblanceolate to narrowly elliptic, the blades (1) $1.5-4 \mathrm{~cm}$ long, $3-8$ (10) $\mathrm{mm}$ wide, thinly pubescent on the upper surface, more densely so to nearly tomentose below, acute to rounded apically, tapering to a pubescent petiole $0.5-2 \mathrm{~cm}$ long; inflorescences cymose, the involucres in small open clusters $0.5-1 \mathrm{~cm}$ across, greenish or reddish; bracts 2 , opposite, 5-10 (12) mm long, 1-1.5 (2) mm wide, linear to linear-lanceolate and acicular, often acerose, the awns straight, 1-2 mm long; involucres campanulate, 3-angled but 6-ribbed, green, corrugate, the tube $3-5 \mathrm{~mm}$ long, pubescent with spreading hairs, with a thin hyaline margin between the teeth, the teeth of two markedly distinct sizes, the longer three prominent and thickened toward the base, 4-6 mm long, divergent, with a straight awn 0.5-1.5 mm long, the alternating smaller teeth $0.3-0.5 \mathrm{~mm}$ long, divergent, the awns $0.2-0.3 \mathrm{~mm}$ long, straight; flowers exserted from the involucre, cylindric, (6) 7-9 $\mathrm{mm}$ long, bicolored, the tube yellow, the lobes white to rose, thinly pubescent without nearly the entire length of the midrib with the hairs not extending beyond the apex of the tepals, on pedicels $0.2-0.4 \mathrm{~mm}$ long, the tepals monomorphic, oblong, entire, united about two-thirds of their length; stamens 9, included, the filaments 4-6 mm long, white, glabrous, the anthers $0.6-0.7 \mathrm{~mm}$ long, oval, yellowish; achenes brown, narrow, $3.5-4 \mathrm{~mm}$ long; $n=20$.

Local and uncommon in gravelly soil on the Sierra San Borja west of Bahía de los Angeles, east central Baja California Norte, México, from 1200-2550 ft elev, flowering from Feb-May.

Specimens Examined: MÉXICO. BAJA CALIFORnIA NORTE: $32 \mathrm{~km}$ E of Rosarito on road to San Borja, 27 Mar 1984, Breedlove 60976 (CAS); Rancho la Huerta, 18 Mar 1966, Moran 12768 (ARIZ, MICH, NY, RSA, SD, UC, US); Mesa la Huerta, 20 Mar 1966, Moran 12829 (DS, SD); $10.7 \mathrm{mi} \mathrm{N}$ of San Borja, 21 Mar 1988, Reveal et al. 6672 (BM, CAS, MARY, MICH, MO, NY, RM, RSA, US, WIS); $1.7 \mathrm{mi}$ N of San Borja, 21 Mar 1988, Reveal et al. 6679 (ARIZ, ASU, BM, BRY, CAS, F, GH, ILL, K, MARY, MICH, MO, NY, ORE, RM, RSA, TEX, US, UTC, WIS); $1 \mathrm{mi}$ W of Mission San Borja, 28 Mar 1977, G.L. Webster 21616 (TEX); 9 mi S of Higuera N of San Borja, 17 Feb 1962, Wiggins 16730 (DAO, DS, ENCB, SD).

The restricted distribution of Chorizanthe mutabilis (from the Latin mutabilis, changeable, the application uncertain) is probably due to a lack of botanical explorations in the more inaccessable areas south of Mission San Borja in the Sierra San Borja and the Sierra la Libertad to the east.

Reveal determined the chromosome number for this species to be $n=20$ based on Reveal et al. 6672 and 6679.

30. Chorizanthe rosulenta Rev., Phytologia 66: 95. 1989.-TYPE: along México Highway 1, $0.8 \mathrm{mi}$ SE of Jaraguay on Jaraguay Grade, Baja California Norte, México, $2700 \mathrm{ft}$ elev, 23 Mar 1988, Reveal et al. 6729 (holotype: MARY!; isotypes: ARIZ, ASU, BM, BRY, CAS, F, GH, K, MICH, MO, NY, ORE, RM, RSA, US, UTC, WIS!).

Spreading, sparsely pubescent annual herb 0.3-0.8 (1) dm high and 0.5-3 (3.5) dm across; leaves basal, narrowly oblanceolate, the blade $0.5-1.5$ (2) $\mathrm{cm}$ long, $2-4(5) \mathrm{cm}$ wide, thinly 
pubescent on the upper surface, more densely so to nearly tomentose below, acute apically, tapering to a pubescent petiole $0.5-2 \mathrm{~cm}$ long; inflorescences cymose, the involucres solitary throughout; bracts 2, opposite, 2-4 mm long, 0.8-1.2 $\mathrm{mm}$ wide, linear and acicular, often acerose, the awns straight, $0.5-1 \mathrm{~mm}$ long; involucres narrowly turbinate, 3-angled but 6ribbed, greenish to reddish, corrugate, the tube 3-4 $\mathrm{mm}$ long, thinly pubescent with curly hairs, with a minute hyaline margin between the teeth, the teeth of two markedly distinct sizes, the longer three prominent and thickened toward the base, $1.5-3 \mathrm{~mm}$ long, divergent, with a short curved awn $0.3-0.7 \mathrm{~mm}$ long, the alternating smaller teeth $0.2-0.4 \mathrm{~mm}$ long, divergent, awnless; flowers exserted from the involucre, cylindric, 4.5-6 $\mathrm{mm}$ long, the tube yellowish at the very base, otherwise rose-pink, the lobes rose-pink, glabrous, on pedicels 0.4-0.5 mm long, the tepals monomorphic, oblong, fimbriate basally, united about a third of their length; stamens 9, mostly included, the filaments $2-3 \mathrm{~mm}$ long, white, glabrous, the anthers $0.5 \mathrm{~mm}$ long, oval, yellowish-white; achenes brown, narrow, $3.5-4 \mathrm{~mm}$ long; $n=20$.

Local and common on volcanic gravelly soil from near Cataviñá to Laguna Chapala, Baja California Norte, México, from 1050-2700 ft elev, flowering from Feb-May.

Specimens Examined: MÉXICO. BAJA CALFORNIA NORTE: $10 \mathrm{mi}$ S of Rancho Santa Catarina on Cañoas Road, 28 Mar 1970, Moran 17034 (ARIZ, COLO, LL, MSC, RSA, PH, SD, UC); top of Jaraguay Grade, 24 Feb 1973, Moran \& Reveal 20254 (RSA, SD, US); $6.4 \mathrm{mi}$ SE of Jaraguay and $16.3 \mathrm{mi}$ NW of Nueva Chapala, above Arroyo Rincanado, 23 Mar 1988, Reveal et al. 6727 (ARIZ, BM, BRY, CAS, MARY, MICH, MO, NY, RM, RSA, US, WIS).

Chorizanthe rosulenta (from the Latin rosulentus, rose-pink, as to color of the tepals and in honor of C. Rose Broome, 1939- ) is most closely related to C. pulchella even though it has flowers that resembles those seen in immature specimens of C. fimbriata var. fimbriata (Reveal 1989a).

31. Chorizanthe pulchella Brandegee, Proc. Calif. Acad. Sci. II, 2: 203. 1889.- TYPE: San Sebastian, Baja California Norte, México, 28 Apr 1889, Brandegee s.n. (holotype: UC!; isotypes: $\mathrm{CAS}, \mathrm{GH}, \mathrm{PH}$ !).

Prostrate to spreading, sparsely pubescent annual herbs 0.3-0.8 (1) dm high and 0.5-8 (10) $\mathrm{dm}$ across; leaves basal, oblanceolate to spatulate, the blades (0.3) 0.5-1.5 cm long, 3-10 (15) $\mathrm{mm}$ wide, thinly pubescent on the upper surface, more densely so to nearly tomentose below, acute to obtuse or rounded apically, tapering to a pubescent petiole $0.5-2 \mathrm{~cm}$ long; inflorescences cymose, the involucres solitary throughout, greenish or reddish; bracts 2, opposite, 2-4 $\mathrm{mm}$ long, 0.7-1 mm wide, linear and acicular, often acerose, the awns straight, 0.4-0.8 mm long; involucres campanulate, 3-angled but 6-ribbed, green, corrugate, the tube 4-5 $\mathrm{mm}$ long, pubescent with curly hairs, with a thin hyaline margin between the teeth, the teeth of two markedly distinct sizes, the longer three prominent and thickened toward the base, 4-6 (9) $\mathrm{mm}$ long, divergent, with a straight awn $0.5-1.5 \mathrm{~mm}$ long, the alternating smaller teeth $0.3-0.5$ $\mathrm{mm}$ long, divergent, awnless; flowers exserted from the involucre, cylindric, 4.5-6 $\mathrm{mm}$ long, bicolored, the tube yellow, the lobes white, glabrous, on pedicels $0.4-0.5 \mathrm{~mm}$ long, the tepals monomorphic, broadly oblong to obovate, laciniate, united about two-thirds of their length; stamens 9, exserted, the filaments 3-4 mm long, yellow, glabrous, the anthers 0.6-0.7 mm long, oval, yellowish; achenes brown, narrow, 3.5-4 mm long; $n=20$ (Reveal \& Moran 1977).

Local and common in sandy to gravelly soil from near Laguna Chapala south to the Desierto el Vizcaino in central Baja California, México, from 200-3600 ft elev, flowering from Feb-May. 
Representative Specimens: MÉXICO. BAJA CALIFORnIA NORTE: 7-8 mi S of Punta Prieta, 29 Mar 1950, Gentry \& Cech 8858 (ARIZ, ASU, MEXU, MICH, RSA, SD, US); Mina Desengano, $16 \mathrm{mi}$ N of Punta Prieta, $30 \mathrm{Mar}$ 1950, Gentry \& Cech 8899 (ARIZ, MEXU, MICH, RSA, US); Aqua del Refugio, 1 Apr 1935, Harbison 11796 (DS, SD); 4 mi NW of Desengano, 3 May 1966, Moran 13123 (RSA, SD, UC); El Portezuelo, SE of Chapala, 9 Apr 1973, Moran 20395 (CAS, LL, MSC, RSA, SD); 2 mi S of El Crucero, 1 Feb 1973, Moran \& Reveal 19625 (ENCB, GH, MO, NY, SD, UC, US); 2 mi N of Yubay, 23 Feb 1973, Moran \& Reveal 20243 (RSA, SD, US); 15.2 mi W of Bahía de los Angeles on road to San Borja, 1 Feb 1960, D.M. Porter 194 (CAS, DS, G, GH, MEXU); 5.5 mi E of Parador Punta Prieta on road to Bahia de los Angeles, 21 Mar 1988, Reveal et al. 6657 (ARIZ, BM, BRY, CAS, MARY, MICH, MO, NY, RM, RSA, US, WIS); 23.5 mi E of Parador Punta Prieta on road to Bahía de los Angeles, 21 Mar 1988, Reveal et al. 6658 (BM, CAS, MARY, MICH, MO, NY, RM, RSA, US, WIS); 10.7 mi N of San Borja, 21 Mar 1988, Reveal et al. 6673 (CAS, MARY, MO, NY, RM, RSA, WIS); 1.8 mi W of San Borja, 21 Mar 1988, Reveal et al. 6680 (CAS, MARY, MO, NY, RM, RSA, US, WIS); 9.4 mi NW of México Highway 1 at Rosarito, 22 Mar 1988, Reveal et al. 6682 (ARIZ, ASU, BM, BR, BRY, CAS, F, GH, ILL, K, LE, MARY, MICH, MO, NY, ORE, RM, RSA, TEX, US, UTC, WIS); along Arroyo Punta Prieta, N of Punta Prieta, 23 Mar 1988, Reveal et al. 6714 (ARIZ, ASU, BM, BRY, CAS, MARY, MICH, MO, NY, RM, RSA, US, WIS); El Crucero, 23 Mar 1988, Reveal et al. 6715 (ARIZ, ASU, BM, BRY, CAS, F, GH, K, MARY, MICH, MO, NY, RM, RSA, US, WIS); Guerro Negro, along México Highway 1, 14 Apr 1967, S.N. Stephenson s.n. (MSC); 17 mi NW of Desengano on road to Bahía de San Luis Gonzaga, 3 mi N of México Highway 1, 6 Jun 1966, Verity s.n. (LA); 2.5 mi S of El Pedregoso, 22 mi S of Cataviñá, 30 Mar 1977, G.L. Webster 21699 (DAV); 34 mi N of Punta Prieta, between Laguna Seca Chapala and Punta Prieta, 15 Apr 1931, Wiggins 5344 (CAS, DS, GH, MICH, NY, POM, RM, UC, US, WTU); 15 mi E of Punta Prieta along road to Bahía de los Angeles, 26 Mar 1960, Wiggins \& Wiggins 15977 (DS, G, GH, K, MICH, RM, TEX, US); 10 mi W of Bahía de los Angeles, 28 Mar 1960, Wiggins \& Wiggins 16011 (ARIZ, BM, DS, G, GH, LE, MICH, RM, TEX, US, WTU); 18 mi S of Punta Prieta, 6 Apr 1963, Wiggins \& Wiggins 18190 (ARIZ, CAS, K, MICH, TEX). BAJA CALIFornia Sur: E base of Sierra de Placeros, $40 \mathrm{~km}$ SE of San Jose de Castro, 24 Mar 1984, Breedlove 60914 (CAS); deflated mesa, 24 km SE of Bahía Tortugas, 7 Mar 1985, Breedlove 62342 (CAS); Sierra Calvario, Sierra Vizcaíno, 10-15 Mar 1947, Gentry 7472 (ARIZ, DS, RSA, UC); 4 mi SE of San Jose de Castro, 5 Feb 1973, Moran \& Reveal 19821 (ASU, COLO, MEXU, SBBG, SD, UCR, US). A total of 66 collections known to us.

Brandegee's (1889) selection of the epithet pulchella (from the Latin pulchellus, beautiful, alluding to the large, bicolored flowers) for this species of Chorizanthe was most apropos for this species is certainly the most beautiful in the genus. The flowers are elegant, an intense, bright yellow in the throat topped by broad, white, laciniate tepals that sparkle in the early morning dew. On the red desert sands near Punta Prieta the numerous large tepals are displayed on spreading branches, and in the early morning when the flowers are fully open, the spreading masses dominate the desert floor. At higher elevation, as near Mission San Borja, the open flowers are not as large or as numerous, yet even here the plants are still striking.

The first published chromosome number for a species of Chorizanthe was that of C. pulchella as reported by Reveal \& Moran (1977). The count was confirmed by Reveal in 1989; his vouchers are Reveal et al. 6657, 6665, 6673, 6680, 6682, 6685, 6714, 6715 and 6722.

32. Chorizanthe flava Brandegee, Proc. Calif. Acad. Sci. II, 2: 202. 1889.-TYPE: Calmalli, Baja California Norte, México, 18 Apr 1889, Brandegee s.n. (holotype: UC!; isotypes: DS, F, GH, NY, PH!).

Chorizanthe vaseyi Bot. Gaz. 15: 64. 1890.-TYPE: in hilly country about $40 \mathrm{mi}$ from the ocean at Lagoon Head, Baja California Norte, México, 6-15 Mar 1889, Palmer 775 (holotype: US!; isotypes: GH, ISC, K, MO, NY, UC, US!).

Prostrate to spreading, sparsely pubescent annual herbs $0.3-0.8(1) \mathrm{dm}$ high and 0.5-5 (6) $\mathrm{dm}$ across; leaves basal, oblanceolate to spatulate, the blades (1) $1.5-4 \mathrm{~cm}$ long, (3) $5-15$ (20) mm wide, thinly pubescent on the upper surface, more densely so to nearly tomentose below, obtuse or rounded apically, tapering to a pubescent petiole $0.5-3 \mathrm{~cm}$ long; inflorescences 
cymose, the involucres solitary throughout or in small open clusters $0.5-1 \mathrm{~cm}$ across, greenish or reddish; bracts 2, opposite, 2-4 mm long, 0.7-1 mm wide, linear and acicular, often acerose, the awns straight, 0.5-1 mm long; involucres campanulate, 3-angled but 6-ribbed, green, corrugate, the tube 3-4.5 mm long, pubescent with spreading hairs, with a thin hyaline margin between the teeth, the teeth of two markedly distinct sizes, the longer three prominent and thickened toward the base, 3-5 (6) mm long, divergent, with a straight awn 1-1.5 mm long, the alternating smaller teeth 0.1-0.3 mm long, divergent, awnless; flowers exserted from the involucre, cylindric, 4-6 mm long, yellow, glabrous, on pedicels $0.4-0.6 \mathrm{~mm}$ long, the tepals monomorphic, oblong, entire and long attenuate, united about two-thirds of their length; stamens 9, exserted, the filaments $3-5 \mathrm{~mm}$ long, yellow, glabrous, the anthers $0.5-0.6 \mathrm{~mm}$ long, oval, yellowish; achenes brown, narrow, 4-4.5 mm long.

Local and uncommon in gravelly soil in the El Arco area of both states in central Baja California, México, from $550-1900 \mathrm{ft}$ elev; flowering from (Dec) Feb-Apr.

Representative Specimens: MÉXICO. BAJA CALFORNIA NORTE: top of grade between Barril and Calmalli, 5 Apr 1947, Harbison 41844 (COLO, MARY, RSA, SD); foot of Cuesta la Ley, 15 Mar 1966, Moran 12652 (ARIZ, CAS, MARY, RSA, SD, UC); Rancho las Palomas, 17 Mar 1966, Moran 12725 (COLO, DS, LL, MICH, SD); El Datillar, $8.5 \mathrm{mi} \mathrm{N}$ of Rancho Miramar, Sierra San Borja, 20 Mar 1966, Moran 12850 (NY, SD); Arroyo de la Purificación, 19 Feb 1973, Moran \& Reveal 20216 (ASU, CAS, ENCB, LL, MO, NY, RSA, SD, US); 2 mi NE of Las Lagunitas, 19 Feb 1973, Moran \& Reveal 20222 (COLO, SD, UC, UCR, US); near Calmalli, Jan-Mar 1898, Purpus 126 (DS, F, UC, K, MIN, US, WU); washes between Rancho Mesquital and Calmalli, 18 Apr 1931, Wiggins 5406 (CAS, DS, GH, MICH, NY, POM, RM, UC, US). BAna CaLjFornia SuR: Laguna del Gallo, 15 mi S of El Arco, 13 Mar 1950, Gentry 8806 (ARIZ, RSA); $32 \mathrm{~km} \mathrm{~S} \mathrm{of} \mathrm{México} \mathrm{Highway} 1$ at the El Arco junction, 20 May 1978, Lane \& Fnyell 2369 (ASU, ENCB, NY, TEX); $18 \mathrm{mi}$ NW of San Ignácio, 24 Mar 1980, Sanders 1201 (UCR); $22 \mathrm{mi}$ S of Pozo Aleman, 4 Mar 1935, Wiggins 7852 (DS, F, GH, UC, US); 15 mi S of El Arco, 22 Dec 1959, Wiggins \& Ernst 637 (DS, MEXU, MICH, RM, UC, US). A total of 22 collections are known to us.

Chorizanthe flava (from the Latin flavus, yellow, as to the color of the flowers) is an evolutionary extension of the general trend seen in the subsect. Flavae. Following the concepts of neotony it would appear that the yellow flower with its entire tepals should be the most advanced expression within the species complex that contains $C$. pulchella and $C$. rosulenta.

\section{Chorizanthe fimbriata Nutt.}

Erect to spreading, pubescent and minutely glandular annual herbs 1-3 (5) dm high and 1-2.5 dm across; leaves basal, elliptic to obovate or spatulate, the blades $0.5-3(3.5) \mathrm{cm}$ long, 2-10 (25) mm wide, thinly pubescent on the upper surface, sparsely tomentose below, obtuse or rounded apically, tapering to a pubescent petiole $0.5-3(5) \mathrm{cm}$ long; inflorescences cymose, the involucres solitary throughout or rarely in small open clusters $0.5-1 \mathrm{~cm}$ across, reddish; bracts 3 at the first node, otherwise 2, opposite, $1-5 \mathrm{~mm}$ long, 0.5-1 mm wide, linear and acicular, often acerose, the awns straight, 1-2 mm long; involucres cylindrical, 3-angled but 6-ribbed, reddish or greenish, finely corrugate, the tube 4-6 (7) $\mathrm{mm}$ long, sparsely to densely pubescent with spreading curly hairs, without a thin hyaline margin between the teeth, the teeth of two sizes, the longer and more prominent three 1-3 mm long, divergent, with a straight awn 1-2.5 (3) mm long, the alternating smaller teeth $0.3-1 \mathrm{~mm}$ long, divergent, the straight awn (0.3) 0.5-1.5 mm long; flowers exserted from the involucre, cylindric, 6-9 (10) $\mathrm{mm}$ long, bicolored, the tube yellow to yellowish-white, the lobes white to rose, the whole becoming dark rose to red with age, glabrous without except for a few to several scattered hairs about midlength along the midribs, on pedicels $0.1-0.2 \mathrm{~mm}$ long, the tepals monomorphic, oblong, fimbriate to laciniate, the outer ones usually longer, broader and more finely 
divided than the inner lobes, united about half of their length; stamens 9 , included, the filaments 3-8 $\mathrm{mm}$ long, whitish to reddish, glabrous, the anthers $0.5-0.7 \mathrm{~mm}$ long, oblong, pink to red; achenes brown, narrow, 3-4 mm long; $n=20,22$ (Hardham 1989).

Sandy to gravelly or rocky places in southern California from Riverside Co. southward to near Santa Cecilia east of El Rosario, Baja California Norte, México, from 100-5500 ft elev, flowering from Mar-Apr (Jul).

\section{Key to the Varieties}

A. Tepals fimbriate with the terminal segment linear to lanceolate, broader than the lateral segments; flowers 6-7 (8) $\mathrm{mm}$ long. 33a. var. fimbriata

AA. Tepals laciniate with the terminal segment linear, scarcely broader than the lateral segments; flowers 8-9 (10) $\mathrm{mm}$ long. 33b. var. laciniata

Goodman (1934) maintained Chorizanthe fimbriata and C. laciniata as distinct species, rejecting Jepson's (1913) reduction of the latter to the varietal rank. Goodman claimed that the two could be distinguished by the length of the tepals and involucre; we have found that neither of these features is diagnostic and we are forced to revert to the differentiation proposed by Jepson and others (Abrams 1944; Munz 1959) relating to the degree of division of the tepal lobes. It is true that the distribution of the two varieties is not wholly sympatric. Still, in portions of southern San Diego Co., California, and just across the border in northern México, mixed populations are common and individual plants cannot be easily placed. One aspect of this is that as the flowers dry the fine divisions of the tepals in these populations tend to become even finer so that an individual that might be more characteristic of var. fimbriata in the field would be rather typical var. laciniata in the herbarium.

Our placement of Chorizanthe fimbriata in the sect. Flavae differs from that proposed by Goodman (1934) who maintained it in sect. Staticoides. The cylindrical involucre would tend to support Goodman's view, but the strongly divided tepals and the southern distribution bespeaks of sect. Flavae. In both instances, however, $C$. fimbriata is somewhat out of place. The glandularity of the species would be unique in either subsection so that it might be appropriate to establish a monospecific subsection for $C$. fimbriata. We are reluctant to do so at this time preferring to await a subsequent monographer who would have an opportunity to study the perennial Chilean species so that evolutionary trends might be more accurately established than is the case presently.

33a. Chorizanthe fimbriata Nutt., Proc. Acad. Nat. Sci. Philadelphia 4: 17. 1848, var. fimbriata. - TYPE: San Diego, San Diego Co., California, Apr 1836, Nuttall s.n. (holotype: PH!; isotypes: BM, GH, K, PH!).

Plants 1-3 (3.5) dm high, 1-2.5 dm across; leaves elliptic to obovate or spatulate, the blades 1-3.5 cm long, 2-10 (25) mm wide; flowers 6-7 (8) $\mathrm{mm}$ long, the tepals with the upper margins divided and fimbriate with a linear to lanceolate, entire, elongated, terminal portion distinctly broader than the lateral segments; $n=20,22$.

Sandy to gravelly or rocky places in southern California from eastern Orange and western Riverside cos. south through San Diego Co. into northern Baja California Norte, México, as far as Santa Cecilia east of El Rosario, from 100-5500 ft elev; flowering from (Mar) Apr-Jun (Jul).

Representative Specimens: MÉXICO. BAJA CALfFornIA NORTE: along México Highway 1, 17.5 mi S of Santo Tomas, 6 Jun 1978, Broome \& J.L. Reveal 2126 (BRY, CAS, MARY, OSC, RSA, WIS); La Turquesa, 22 mi SE of El Rosario, 7 Feb 1947, Constance 3122 (CAS, COLO, DAO, DS, F, GH, K, LL, MEXU, MICH, MO, NY, 
SD, UC, US, WTU); 3.5 mi from Santa Cecilia, 24 Apr 1980, Davis \& Lightowlers 66895 (E); Tecate, 30 May 1932, Fosberg 8279 (DS, NO, PENN, POM, SBBG); between San Augustin and El Rosario, Mar 1947, Gentry 7620 (ARIZ, DS, MICH, RSA, SD, UC); 20-25 mi E of El Rosario, Sierra San Jose, along main road, 7 Apr 1950 , Gentry \& Cech 9029 (ARIZ, MICH, RSA, US); near Rancho Arenosa, 15 mi NW of San Fernando, 12 Apr 1947 , Harbison 41836 (DS, RSA, SD); Portezuelo de Jamau, Sierra Juárez, 9 May 1963, Moran 10985 (DS, SD, UC); La Turquesa, 24 Mar 1970, Moran 16865 (COLO, LL, MARY, MSC, RSA, SD); San Juan de Dios, 30 Apr 1973, Moran 20601 (CAS, ENCB, LL, RM, SD); $4.3 \mathrm{mi}$ W of El Arenoso, 24 Feb 1973, Moran \& Reveal 20268 (CAS, RSA, SD); $19.5 \mathrm{~km}$ SE of San Vicente, 5 Apr 1958, Raven et al. 12291 (ARIZ, CAS, DS, GH, LA); summit of Aguajito Grade, 2 km E of Rancho Aguajito, 18 Apr 1958, Raven et al. 12512 (DS, GH, RSA, UC); along México Highway 1, $2.8 \mathrm{mi}$ NNW of El Progresso, 18 May 1988, Reveal 6815 (BRY, CAS, MARY, MEXU, MO, NY, OSC, RSA, WIS); 3 mi E of Uruapan, 21 May 1988, Reveal 6837 (BM, BRY, CAS, G, MARY, MEXU, MO, NY, OSC, RM, RSA, SMU, US, UTC, WIS); along México Highway 3, $7.1 \mathrm{mi}$ SW of Francisco Zarco, 21 May 1988, Reveal 6843 (CAS, MARY, MEXU, MO, RSA, WIS); 0.5 mi ESE of Santa Cecilia, 24 Mar 1988, Reveal et al. 6730 (ARIZ, ASU, BM, BRY, CAS, F, GH, K, MARY, MICH, MO, NY, RM, RSA, US, UTC, WIS); 4.7 mi WSW of San Telmo, 25 Mar 1988, Reveal et al. 6767 (BM, CAS, MARY, MICH, MO, NY, RM, RSA, US, WIS); Rancho La Suerte, S end of Sierra San Pedro Martír, 2 Jun 1963, Thorne 31906 (BM, RSA, WIS); near Rancho el Criprés, 2 Jun 1963, Thorne 31972 (GH, K, MICH, RSA); Santo Tomas Grade, 5 Apr 1931, Wiggins 5177 (CAS, DS, F, GH, LA, LL, MICH, NY, POM, RM, UC, US, WTU); between Quail Springs and San Fernando, 11 Apr 1931, Wiggins 5273 (CAS, DS, GH, MICH, MO, NY, RM, UC, US, WTU); W of ranch house at Rancho San Jose, 6 May 1941, Wiggins 9763 (DS, MICH, UC, US); Valle Trinidad, 4 mi E of village, 3 Apr 1960, Wiggins \& Wiggins 16057 (DS, G, MICH, TEX). UNTTED STATES. CALIFornla: Orange Co.: Los Pinos Petrero, Santa Ana Mountains, 18 Jun 1935, Everett 7197 (ARIZ, DS, MO, OKL, RSA, WTU); $2 \mathrm{~km} \mathrm{~N}$ of California Highway 74, $1.1 \mathrm{~km} \mathrm{NNW}$ of El Cariso Campground, Santa Ana Mountains, 20 Jul 1982, F.M. Roberts 756 (UCSB). Riverside Co.: Bachelor Mountain, E end of Lake Skinner, 1 May 1986, Boyd 1817 (HSC, NY, RSA, TEX, UCR); San Mateo Canyon, 17 Jun 1946, Fiker 3583 (BA, IDS, ILL); 3 mi E of Murrieta, 18 May 1922, Munz \& Johnston 5318 (OKL, POM, UC); Los Alamos Canyon, Elsinore, 9 Jun 1947, M.M. Thompson 2068 (RSA); Rancho California, Mesa de Burro, Santa Rosa Plateau, 29 Aug 1975, Thorne et al. 47322 (RSA). San Diego Co.: Mission Hills, San Diego, 8 May 1903, Abrams 3426 (BM, DS, E, F, G, GH, K, LE, MIN, MO, NEB, NMC, NY, PH, POM, SMU, UC, US, Z); Point Loma, 16 Mar 1962, Bacigalupi et al. 8255 (JEPS, WS); San Diego, 25 May 1902, Brandegee 1631 (B, CAN, CAS, F, G, GH, K, LE, MIN, MSC, NY, POM, RM, UC, US); San Diego, 1906, K. Brandegee s.n. (BKL, DS, MIN, POM, RM, UNLV, US); La Jolla, 3 Jun 1914, Clements \& Clements 51 (COLO, F, GH, ILL, MO, NEB, NY, PENN, PH, UC, UCSB); Flinn Springs, 19 Jun 1932, Epling et al. s.n. (BM, CAS, DS, F, K, MARY, MIN, ND, NO, NY, RSA, UC, WTU); Lakeside, 8 May 1906, Grant 6872 (ARIZ, DS, MARY, POM, UC); 3 mi E of Bonsal, 18 May 1973, Henrickson 9915 (CHSC, ENCB, HSC, RSA, TEX); near Fallbrook, 15 May 1920, Munz \& Hanwood 3852 (DS, POM, RM, US); $10 \mathrm{mi}$ W of Dulzura, 15 May 1932, Munz \& Johnston 12618 (F, MO, MONTU, NO, POM, UC); San Luis Rey River, near Pala, 31 May 1897, Parish 4399 (BM, GH, JEPS, K, MO, MSC, NY, US, VT); San Diego, May 1882, Parry s.n. (F, GH, LE, MIN, MO, NY, ORE, UC, US, VT); San Diego, 29 Apr 1882, Pringle s.n. (CAN, F, G, K, LE, MIN, NY, PENN, PH, US, VT, WU); View Point Ranch, N side of Lake Hodges, 26 May 1935, Purer 6657 (BKL, CM, DS, MIN, ND, RSA, SD, WTU); along Rainbow Heights Road, $1 \mathrm{mi}$ E of Old U.S. Highway 395 in Rainbow, 22 May 1988, Reveal 6860 (BM, BRY, CAS, MARY, MO, NY, OSC, RM, RSA, US, UTC, WIS); Palomar Mountains, along East Grade Road (County Road S-7), 3.2 mi SE of Palomar Mountain, 28 Jun 1987, Reveal \& Broome 6621 (ARIZ, ASU, BM, BRY, CAS, F, MARY, MICH, MO, NY, RM, RSA, TCD, US, WIS); Mt. Helix, 3 mi E of La Mesa, 7 Jul 1935, Rose 35243 (MICH, MIN, NY, VT, W, WTU); near Old Spanish Lighthouse, Point Loma, 26 May 1931, Wolf 2062 (MARY, MONTU, NY, POM, RSA, UC). A total of 326 collections are known to us.

There are two collections of var. fimbriata (from the Latin fimbriatus, fringed, alluding to the cut tepal lobes) that we are disregarding. The first is a 1854 Thomas collection labelled "Rio Colorado," This collection was supposedly collected in Arizona, but this is unlikely and the plant was actually found in San Diego Co., California. The second is a M.E. Jones collection gathered in May 1882 at Pasadena in Los Angeles Co. This might have occurred as an ephermal weed or even a garden introduction, but as the plant has not been rediscovered this far north we have concluded it was collected elsewhere and mislabelled.

Hardham (1989) reported chromosome numbers for var. fimbriata ranging from $n=20-22$ with $n=20$ by far the most common. Reveal found only $n=20$ in the material he examined (vouchered by Reveal et al. 6730, 6733, 6767, Reveal 6815 and 6837). 
33b. Chorizanthe fimbriata Nutt. var. laciniata (Torr. in Parke) Jepson, Fl. Calif. 1: 394. 1913. Chorizanthe laciniata Torr. in Parke, Pacif. Railr. Rep. Parke, Bot. 7: 19. 1857.TYPE: San Felipe, Imperial Co., California, May 1855, Antisell s.n. (holotype: NY!; isotypes: GH, ISC!).

Plants 1-2 (2.5) dm high, 1-2 dm across; leaves obovate or spatulate, the blades $1-2(3) \mathrm{cm}$ long, 2-10 (15) $\mathrm{mm}$ wide; flowers 8-9 (10) $\mathrm{mm}$ long, the tepals with the upper margins divided and all laciniate with the elongated terminal segment scarcely broader than the lateral ones; $n=20$.

Sandy to gravelly or rocky places in southern California from southwestern Riverside cos. south through San Diego and western Imperial cos. into northern Baja California Norte, México, as far south as San Quintín, from $1300-4875 \mathrm{ft}$ elev; flowering from (Mar) Apr-Jun (Jul).

Representative Specimens: MÉXICO. BAJA CALIFORnIA NORTE: La Vinata Romero, 7 mi ESE of Santa Catarina, 24 Apr 1962, Broder 812 (DS, MEXU, UCSB, US); along the road to Rancho Mike and Rancho El Picacho, 5.9 mi SW of México Highway 3, Sierra San Pedro Martír, 20 May 1981, T.F. Daniel 1384 (ASU, MICH, NY); 40 km SE of La Rumorosa, Sierra Juárez, 18 May 1986, Levin et al. 1685 (ARIZ, SD); El Condor, 31 mi E of Tecate, 29 Jun 1962, Moran 9793 (DS, RSA, SD, UC); 2.5 mi NW of El Rodeo, 21 May 1967, Moran 13895 (ARIZ, RSA, SD); N slope of Cerro Blanco, 15 Jun 1969, Moran 16154 (RSA, SD); E slope of Cerro Bola, 6 Jun 1970, Moran 17809 (RSA, SD); Mission San Pedro Martír, 1 Jun 1975, Moran 22147 (CAS, SD); Arroyo Agua Grande, 9 km S of La Rumorosa, Sierra Juárez, 30 May 1982, Moran 30827 (ARIZ, SD); Tecate Mountains, 2 Jul 1884, Orcutt s.n. (CM, F, PENN, UC); 1.8 mi NW of Lazaro Cardenas, 20 Apr 1985, Thorne \& Charlton 60279 (BRY, MARY, NY, RSA, UC, UCR); 3 km S of La Rumorosa, 8 May 1985, Thome \& Wisura 60444 (MARY, RSA, UC, UCR); 0.5-2.3 mi S of El Condor, 9 May 1985, Thorne \& Wisura 60560 (CAS, MARY, RSA); 7 mi N of La Huerta, 15 May 1948, Wiggins 11854 (DS, SD, US). UNITED STATES. CALIFORNIA: Imperial Co.: E side of Mountain Springs Grade, 3 May 1930, Rowntree s.n. (SBBG). Riverside Co.: E side of Dripping Springs Campground between Aguanga and Temecula, 22 May 1980, Ertter \& Strachan 3489 (MARY, UC); below Anza Tablet, at head of Coyote Canyon, 31 May 1937, Munz 15116 (CAS, DS, GH, MO, POM, RM, UC); Aguanga, Jun 1882, Parish \& Parish 1612 (BM, F, G, MO, VT, WS); dry hills between Terwilliger Valley and Tule Canyon, San Jacinto-Santa Rosa mountains, 22 Aug 1967, Ziegler 220 (UCR). San Diego Co.: Jacumba, 31 May 1903, Abrams 3661 (DS, E, F, GH, K, MIN, NY, POM); Witch Creek, Jun 1894, Alderson s.n. (DS, NDG, POM, UC); San Luis Rey, Jul 1885, Brandegee s.n. (COLO, F, G); along Interstate $8,5.4 \mathrm{mi} \mathrm{W}$ of Campo Boulevard and $2.9 \mathrm{mi} \mathrm{E}$ of the Crestwood Road Exit to Live Oak Springs, 3 Jun 1978, Broome 2118 (BRY, CAS, MARY, MO, OSC, RSA, WIS); Potrero, 24 Jun 1884, Cleveland s.n. (F, SD, UC); head of Box Canyon near Mason Valley, 10 May 1932, Duran 3195 (BKL, BM, BR, CAN, DAV, DS, F, G, GH, ISC, K, LE, MARY, MIN, MO, MSC, NO, NY, POM, RM, SD, UC, US, UTC, WIS, WTU); Guatay Mountain, 26 Jun 1935, Epling \& Robison s.n. (ISC, LA, NO, SD); foot of Jacumba grade at Mountain Springs, 1 May 1932, Ferris \& Bacigalupi 8246 (DS, F, MICH, POM, SD, UC); 10 mi NW of Warner Hot Springs, 6 May 1932, Fosberg 8277 (LA, ND, NO, PENN, SBBG); along Cottonwood Creek, $1 \mathrm{mi}$ NW of Buckman Springs, 23 Jun 1938, Ownbey \& Ownbey 1658 (DAO, GH, F, MICH, MIN, NY, RM, US, WS); along California Highway 188, $1.5 \mathrm{mi}$ N of Tecate, 21 May 1988, Reveal 6847 (BM, BRY, CAS, MARY, MO, NY, OSC, RM, RSA, US, UTC, WIS); along Corral Canyon Road, $1.1 \mathrm{mi}$ W of Buckman Springs Road N of Lake Morena, 21 May 1988, Reveal 6852 (BM, BRY, CAS, G, MARY, MEXU, MO, NY, OSC, RM, RSA, US, UTC, WIS); 4.7 mi E of the N end of El Capitan Lake, 15 Jun 1954, J.M. Tucker 2712 (ARIZ, DAV, MIN); Smith's Mountain, Jun 1880, Vasey 535 (ISC, NY, PH, US); $0.5 \mathrm{mi}$ W of Canyon City on U.S. Highway 94 between Potrero and Campo, 28 Jun 1941, Wolf 10918 (DS, NY, OKL, RSA, WTU). A total of 194 collections known to us.

The flowers of var. laciniata (from the Latin laciniatus, finely fringed, alluding to the finely cut tepal lobe), in their extreme, are spectacular. The brilliant rose to red color coupled with the fine, almost hairlike divisions along the margins of the tepals can provide even the most jaded collector with a brief moment of wonder. The stems and branches are generally a darker red, and as the plants are often weedy in the deep sands along the margins of the yellowish-green chaparral, they are immediately obvious. 
As a small aside we should note that we have credited the publication of Chorizanthe laciniata to Torrey's 1857 paper in Parke's volume of the Explorations and Surveys for a Railroad from the Mississippi River to the Pacific Ocean. Stafleu and Cowan (1986) report the existence of a preprint that was likely available as early as 1856 and it may be that that was the first valid place of publication of the name.

Reveal counted the var. laciniata and found only $n=20$ (vouchered by Reveal 6847 and 6852).

IVB. Chorizanthe R. Br. ex Benth. sect. Acanthogonum (Torr. in Whipple) Torr. \& A. Gray, Proc. Amer. Acad. Arts 8: 197. 1870. Acanthogonum Torr. in Whipple, Pacif. Railr. Rep. Whipple, Bot. 4: 132. 1857.-TYPE: Acanthogonum rigidum Torr. in Whipple.

Plants prostrate to erect; leaves oblanceolate to elliptic or round; flowering stems slender, not disarticulating at each node; bracts awned; involucres cylindrical to campanulate, not ventricose basally, 3-, 5- or occasionally 6-toothed and 3-angled, without a scarious margin, the teeth short and uncinate or long and straight, sometimes with the anterior one more prominent; flowers solitary, rarely two, white to rose or yellow, the tepals thinly to densely pubescent, mostly long pedicellate; stamens 6 or 9, attached faucially at or near the top of the floral tube.

A small but variable section of five species each referred to a monospecific subsection, these widely distributed in western North America from Washington and Idaho south through California, Nevada and Utah into Arizona and northwestern México in Sonora and Baja California Norte, from -230 ft below sea level to $7800 \mathrm{ft}$ elev, flowering from Feb-Jul.

\section{Key to the Subsections}

A. Involucres urceolate to campanulate, 3-angled and 3-, 5- or 6-ribbed, the tube 1.5-3 mm long, not transversely corrugate; flowers densely pubescent, $1.5-2 \mathrm{~mm}$ long; stamens (6) 9.

B. Involucral teeth 5(6); flowers white to rose; embryo curved; awns uncinate, the longest 1-2 mm long; branches dark green or red; Central Valley of California south to extreme northern Baja California Norte, México. IVB(1). Parvatia (p. 176)

BB. Involucral teeth 3; flowers yellow.

C. Plants erect; involucres urceolate with the longer awns straight and on a tooth $5-10 \mathrm{~mm}$ long; embryo curved; branches green to dark green; widespread in the deserts of western Nevada and eastern California into southwestern Utah and western Arizona south to northwestern Sonora, México. ..

IVB(2). Acanthogonum (p. 179)

CC. Plants prostrate; involucres campanulate with the longer awns uncinate and on a tooth $1.8-2 \mathrm{~mm}$ long; embryo straight; branches yellowish-green and gray, endemic to San Diego Co., California.

IVB(3). Exolophyta (p. 182)

AA. Involucres cylindrical, 3-angled and 3- or 5-ribbed, the tube 3-4.5 mm long, flowers thinly pubescent, $1.5-2.5$ mm long; stamens 6 or 9 .

B. Involucral teeth 5, one much enlarged and leaflike, the tube finely corrugate; stamens 9; southeastern Washington and southwestern Idaho south through Oregon, eastern California and Nevada to southern California and southwestern Utah.

IVB(4). Ansata (p. 183)

BB. Involucral teeth 3, all equal, the tube markedly transverse corrugate; stamens 6; southeastern California and southern Nevada southward through western and central Arizona into northwestern México.

IVB(5). Chorizanthella (p. 186)

Goodman (1934) referred two of the species placed here in the sect. Acanthogonum (from the Greek acanthos, a prickly plant, and gony, node, alluding to the spiny bracts) to Chorizanthe and two others to Acanthogonum. Chorizanthe watsonii, C. corrugata and $C$. orcuttiana were retained in Chorizanthe while $C$. rigida and $C$. polygonoides were placed in 
Acanthogonum. When Torrey (1857) proposed Acanthogonum, he questionably placed $C$. comugata in his new genus. This practice ended when Torrey and Gray (1870) submerged the genus, noting that the discovery of both $C$. watsonii and $C$. polygonoides removed all unique features save the faucial position of the stamens. Parry (1884) defined the sect. Acanthogonum to include only the two species with curved embryos, $C$. polygonoides and the type of the taxon, $C$. rigida. As for $C$. comugata, $C$. watsonii and $C$. orcuttiana, or the species characterized by straight embryos, these were placed in a new section, Chorizanthella.

The sect. Acanthogonum may be characterized as a group of annual plants with long pedicellate flowers bearing stamens inserted on a floral tube. The existence of a curved embryo, which was used by Goodman $(1934,1955)$ as the basis for his recognition of Acanthogonum, is once again lowered in significance much as we have done with Chorizanthe spinosa and $C$. membranacea.

IVB(1). Chorizanthe R. Br. ex Benth. subsect. Parvatia Rev. \& Hardham, subsect. nov.TYPE: Chorizanthe polygonoides Torr. \& A. Gray.

A subsect. Acanthogono involucris 5(6) lobatis et embryoibus curvatis differt.

Plants prostrate, villous annual herbs; leaves oblanceolate to elliptic; inflorescences in small clusters; bracts similar to the basal leaves, awnless; involucres campanulate, 3-angled and 5(6)-ribbed, corrugate, the three prominent teeth spreading with uncinate awns, the two or three minor ones erect and straight awns; flowers white to rose, densely pubescent; stamens (6) 9; achenes dark brown to black, globose, the embryo curved.

A monospecific taxon mainly of the mountains surrounding the Central Valley of California from Modoc Co. south to Calaveras Co. in the Sierra Nevada and in the Coast Ranges from Lake Co. to Santa Barbara Co., then disjunct in the mountains and along the coast of western Riverside and San Diego cos., south into extreme northern Baja California Norte, México, from $100-4750$ ft elev; flowering from Apr-Jul.

When Torrey and Gray (1870) described Chorizanthe polygonoides, Gray (the actual author of the paper) characterized the species as an "insignificant weedy plant..." We have noted this in our selection of the subsectional name, Parvatia (from the Latin parvitis, insignificance, as the type species was characterized by its authors).

\section{Chorizanthe polygonoides Torr. \& A. Gray}

Prostrate, villous annual herbs $0.1-0.5 \mathrm{dm}$ high and 0.3-2 (2.5) dm across; leaves basal, oblanceolate to elliptic, the blades $0.3-1 \mathrm{~cm}$ long, $2-3 \mathrm{~mm}$ wide, thinly pubescent on both surfaces, acute to rounded apically, tapering to a pubescent petiole $0.5-1 \mathrm{~cm}$ long; inflorescences cymose, the involucres in small clusters $0.5-1 \mathrm{~cm}$ across even at the dichotomies, greenish or reddish; bracts 2, opposite, similar to the basal leaves, oblanceolate or narrowly elliptic to linear-lanceolate, $0.3-1 \mathrm{~cm}$ long, $1-3 \mathrm{~mm}$ wide, awnless; involucres campanulate, 3-angled but 5-6-ribbed, greenish or reddish, corrugate, the tube $1.5-2.5 \mathrm{~mm}$ long, thinly pubescent but more so on the teeth, the teeth of two sizes, the longer and more prominent three thickened toward the base, 1.5-3 mm long, spreading, with hooked awns 1-2 mm long, the smaller two or three spinelike, 1-2 mm long, erect or nearly so; flowers included to slightly exserted from the involucre, cylindric, 1.5-1.8 (2) $\mathrm{mm}$ long, white to rose, densely pubescent without, on slightly winged pedicels $0.5-0.8$ (1) $\mathrm{mm}$ long, the tepals monomorphic, oblong, obtuse to truncate or minutely emarginate, slightly spreading, united more than two-thirds of their length; stamens (6) 9, slightly exserted, attached to the top of the floral tube, the 
filaments 0.8-1 mm long, white to reddish, glabrous, the anthers $0.2-0.3 \mathrm{~mm}$ long, oval, reddish; achenes dark brown to black, globose, 2-2.5 mm long.

Local and widespread in sandy to gravelly places in the mountains of northern and central California in the foothills of the Sierra Nevada from Modoc Co. south to Calaveras Co. and across the Sacramento Valley to the Coast Ranges from Lake Co. to Santa Barbara Co., then disjunct to southern California in western Riverside and San Diego cos. southward into extreme northern Baja California Norte, México, from 100-4500 ft elev; flowering from Apr-Jul.

\section{Key to the Varieties}

A. Involucral tubes 2-2.5 mm long with the longer teeth $1.5-2 \mathrm{~mm}$ long; northern and central California south to Santa Barbara Co. 34a. var. polygonoides

AA. Involucral tubes 1.5-2 mm long with the longer teeth 2-3 mm long; southern California and Baja California Norte as far north as Riverside Co. 34b. var. longispina

Goodman (1934) initially did not differentiate between the southern and northern expressions of Chorizanthe polygonoides, but when he reviewed the genus Acanthogonum in 1955, he divided the species into two variants. The morphological distinction is rather weak but the geographic distinction absolute.

In the field the individual plants are often difficult to see. The plants, especially in poor conditions, are often inconspicuous, their dark red to almost blackish hue obscured against the volcanic gravel the species often can be found growing in. Even at full anthesis the plant can appear to be dried up and dead. It is likely for these reasons that many botanists fail to collect it.

In general flowers of this species have nine stamens. Individual flowers may have fewer stamens, but only one individual from El Dorado Co. was seen with six anthers consistently.

Chorizanthe polygonoides Torr. \& A. Gray, Proc. Amer. Acad. Arts 8: 197. 1870, var. polygonoides. - Acanthogonum polygonoides (Torr. \& A. Gray) Goodman, Ann. Missouri Bot. Gard. 21: 91. 1934. - TYPE: Reservoir Hill near Placerville, El Dorado Co., California, 1860-1867, Rattan s.n. (holotype: GH!; isotypes: ISC, K, NY, UC, US!).

Plants generally greenish; involucres with tubes $2-2.5 \mathrm{~mm}$ long, the longer and more prominent awns $1.5-2 \mathrm{~mm}$ long; $n=20$.

Local and widespread on volcanic soils in the mountains of the Sierra Nevada from Modoc Co. south to Calavaras Co., then across Sacramento Valley to the Coast Ranges on a variety of soil types and south from Lake Co. to Santa Barbara cos., California, 450-4700 ft elev; flowering from Apr-Jun.

Representative Specimens: UNTTED STATES. CALIFORnIA: Alameda Co.: Oakland Hills (Leona), 29 May 1891, K. Brandegee s.n. (UC). Amador Co.: road between Ione and Watts Station, $6.5 \mathrm{mi}$ N of Ione, 31 May 1962, Bacigalupi \& Heckard 8560 (JEPS); along California Highway 104, $1 \mathrm{mi} \mathrm{S}$ of the junction of Highway 16, $7 \mathrm{mi} \mathrm{N}$ of Ione, 28 Apr 1962, Hutchison 2365 (JEPS, US); E of Tonzi Road, $3.7 \mathrm{mi}$ W of California Highway 16 and E of Ione, 2 May 1974, McNeal 1446 (CPH). Butte Co.: W of Paradise along Neal Road, 26 Apr 1939, Heller 15382 (DS, MO, NY, PH, WTU); Butte College Campus, N of the junction of Pentz and Clark roads, 14 Apr 1982 , Jokerst 1529 (CHSC); Chico, May 1883, Parry s.n. (F, UC, US, VT); Paradise, 0.2 mi S of Bennett Road along South Libby Road, 3 Jun 1988, Reveal 7007 (BRY, CAS, MARY, MO, OSC, RSA, WIS); S side of Humbug Road, $2 \mathrm{mi}$ SW of Nimshew, 4 Apr 1984, Taylor \& Oswald 5392 (CHSC, MO). Calaveras Co.: Table Hills, near Sheep Ranch, 18-30 May 1895, Davy 1612 (UC). El Dorado Co.: S of Eight-mile House and E of Camino, 1 mi below U.S. Highway 50, 31 May 1962, Bacigalupi \& Heckard 8574 (JEPS, WTU); Placerville, 9 Apr 1938, Jepson 18627 (JEPS). Lake Co.: above Siegler Creek, S of Siegler Springs, near Clear Lake, without date, Anderson \& Smith 603 (DAO, ILL, OKL, SMU, TEX); between Cobb Mountain and Adams Springs on Binkley Ranch, 25 Jun 1933, 
Jussel 134 (CAS, OKL); hills about Scotts Valley, 6 mi NW of Lakeport, 28 May-2 Jun 1902, Tracy 1724 (UC, WTU). Marin Co.: Tamalpais, 14 Jun 1891, K. Brandegee s.n. (COLO, F, G, MIN, UC); Rock Springs, Mt. Tamalpais, 10 Jun 1962, Heermann 17409 (US, W); above Tiburon, 29 Apr 1950, Raven 1932 (DAO, RSA). Modoc Co.: Big Valley, 29 Jun 1894, Baker \& Nutting s.n. (GH, MIN, UC); 5 mi N of Lookout, 15 Jun 1940, Eastwood \& Howell 8300 (CAS, POM). Monterey Co.: The Indians, Santa Lucia Mountains, 23 Mar 1963, Keefe 636 (UCSB). Napa Co.: Mt. St. Helena, 6 Jun 1915, Eastwood 4665 (BM, CAS, GH); Palisades, 23 May 1937, Jussel s.n. (CAS, ISC); E side of Devilhead Road, Cedar Valley, 4 air mi S of Knoxville, 15 May 1965, J.M. Tucker 3827 (DAV, LA, RSA). Nevada Co.: Grass Valley, 25 May 1919, Heller 13199 (CAS, DS, F, G, GH, ILL, MO, NY, PENN, PH, RSA, UC, US, WIS, WTU); along California Highway 20 in Grass Valley between Sunset View and Alta Hill, 3 Jun 1988, Reveal 7008 (BM, BR, BRY, CAS, CLEM, G, K, MARY, MEXU, MO, NY, OSC, RM, RSA, SMU, US, UTC, WIS). Sacramento Co.: Folsom, 4 May 1928, Vortriede s.n. (CAS). San Luis Obispo Co.: between Bee Rock and the Nacimiento River, 7 May 1958, Hardham 3228 (CAS); 18 mi E of Creston on the La Panza Road, 6 May 1952, Hoover 8160 (CAS, OBI). Santa Barbara Co.: E of Juncal Public Campground, Santa Ynez River watershed, 8 May 1964, Chandler 1611 (DS, OKL, SBBG). Santa Clara Co.: Page Mill Road, 4 mi from California Highway 5, 25 Jun 1953, Hesse 1136 (DS). Shasta Co.: along the Whitmore Road, 7 mi NE of Millville, 23 Apr 1958, Bacigalupi et al. 6310 (JEPS). Solano Co.: $0.7 \mathrm{mi}$ S of Rio-Dixon Road on Cook Lane, 11.5 mi S of Dixon, 3 May 1967, Mc Caskill \& Cook 723 (ARIZ, CAS, DAO, DAV, DS, LA, MIN, RSA, UC, UTC, WTU). Sonoma Co.: $6.6 \mathrm{mi}$ W of Hopland, 15 May 1948, F.W. Hoffman 2705 (UC). Stanislaus Co.: along West Fork of Upper Dominici Creek, 1.5 mi W of La Grange, 7 Apr 1969, P.S. Allen 143 (DAV); near headwaters of Arroyo del Puerto, Red Mountains, Mount Hamilton Range, 18 May 1935, Sharsmith 3114 (UC). Tehama Co.: 9 mi E of Paynes Creek, 14 May 1954, Barneby \& Howell 11485 (CAS); SE of Vina along Pine Creek off Meridian and Barber roads on the Wurlitzer Ranch, 2 Apr 1978, Schlising 3215 (CHSC). Tuolumne Co.: 3 mi S of Chinese Camp, 9 May 1938, Hoover 3381 (UC, US); 1.2 mi from California Highway 108 along Cedar Springs Road toward Tuolumne City, 22 May 1971, Wiggins 21153 (DS). Unknown Co.: without location data, 1883, Parry s.n. (B, F, K, MIN, NY, ORE, UC, US). A total of 111 collections are known to us.

The var. polygonoides (Greek poly-, many, gony, knee, and -oides, resembling, having the aspect of species in the genus Polygonum, perhaps alluding to its weedy nature) is typically found on volcanic soils on the lower foothills of the Sierra Nevada and the Coast Ranges. In portions of its range, the variety is found in unusual edaphic situations, such as on Cretaceous sandstone at The Indians in Monterey Co. and on conglomerates at Bee Rock in San Luis Obispo Co., but nearly always in grassy areas in the open among shrubs. The plants are often locally restricted in their distribution so that individual populations can be widely dispersed over the entire range of taxon.

Reveal determined the chromosome number for var. polygonoides to be $n=20$; his voucher is Reveal 7007.

Chorizanthe polygonoides Torr. \& A. Gray var. Iongispina (Goodman) Munz, Aliso 4: 89. 1958. Acanthogonum polygonoides (Torr. \& A. Gray) Goodman var. longispinum Goodman, Leafl. W. Bot. 7: 236. 1955. Chorizanthe polygonoides Torr. \& A. Gray subsp. longispina (Goodman) Munz, Fl. S. Calif. 673. 1974. - TYPE: San Diego, San Diego Co., California, 25 Apr 1903, K. Brandegee 3412 (holotype: UC!; isotypes: B, CAN, CAS, DS, E, F, G, GH, K, L, MICH, MO, MSC, NY, POM, SBBG!).

Plants generally reddish; involucres with tubes $1.5-2 \mathrm{~mm}$ long, the longer and more prominent awns $2-3 \mathrm{~mm}$ long; $n=20$.

Local and uncommon on sandy to gravelly soil in the mountains of western Riverside and San Diego cos., California, southward into extreme northern Baja California Norte, México, and disjunct along the coast in the San Diego area, from $100-4750 \mathrm{ft}$ elev, flowering from Apr-Jun.

Representative Specimens: MÉXICO. BAJA CALIFORnIA NORTE: $1 \mathrm{mi}$ SE of Cerro Matomi, 4 May 1973, Moran 20819 (ARIZ, CAS, ENCB, MEXU, NY, RSA, SD, UC, US); 0.5 km S of El Condor, Sierra Juárez, 15 Apr 1979, Moran 27028 (MO, RSA, SD); 45 mi SE of Tecate, 14 May 1925, Munz 9603 (POM, UC, US); 48 mi SE of Tecate, 
14 May 1925, Peirson 5857 (DS, RSA, UC). UNITLD STATES. CALIFORNIA: Riverside Co.: Harford Springs County Park, Gavilan Hills, 2 Apr 1986, Boyd 1587 (HSC, NY, RSA, TEX, UCR); E side of Dripping Springs Campground near highway 79, between Aguanga and Temecula, 22 May 1980, Ertter \& Strachan 3490 (MARY); 0.2 mi NW of the Kenworthy Ranger Station, Garner Valley, San Jacinto Mountains, 1 May 1980, Sanders 1365 (UCR); Rancho California, Mesa de Burro, Santa Rosa Platcau, 29 Aug 1975, Thorne et al. 47305 (RSA). San Diego Co.: Cuyamaca Lake, 25 Jun 1903, Abrams 3890 (DS, GII, MO, NY, US); 1 mi S of road to Cuyamaca, E side of Lake Cuyamaca, Laguna Mountains, 26 May 1980, Ertter \& Strachan 3535a (MARY, UC); Kearney Mesa, 2 Apr 1962, Hardham 8936 (CAS, SBBG); E of a water tower, 5900 block, Kearney Villa Road, Kearney Mesa, 27 Apr 1978, Moran 25562 (ARIZ, DAV, MSC, RSA, SD); San Diego, Apr 1884, Orcutt s.n. (BM, ISC, ORE, US); mesas, San Diego, 21 Apr 1884, Orcutt s.n. (CM, F, NY, UC, VT); Cuyamaca Rancho State Park, 5 mi N of Descanso, 21 May 1988, Reveal 6857 (MARY); Miramar Naval Air Station, 25 Mar 1971, H.V. Witham 1285 (SD). A total of 70 collections are known to us.

The southern disjunct, var. longispina (from the Latin longus, long, and spinus, spine, alluding to the longer involucral awns compared to the typical variety), is not always morphologically distinct from the more northern var. polygonoides. The difference in involucral tube and awn lengths is such that overlapping does occur. The more northern plant is a more harsh plant to the touch than its southern counterpart, the difference being in the degree of compactness of the individual plants in both areas.

IVB(2). Chorizanthe R. Br. ex Benth. subsect. Acanthogonum (Torr. in Whipple) Rev. \& Hardham, comb. et stat. nov. Acanthogonum Torr. in Whipple, Pacif. Railr. Rep. Whipple, Bot. 4: 132. 1857. - TYPE: Acanthogonum rigidum Torr. in Whipple.

Chorizanthe R. Br. ex Benth. "Group" Campylosperma C. Parry, Proc. Davenport Acad. Nat. Sci. 4: 50. 1884. Chorizanthe sect. Campylosperma (C. Parry) Dammer, Nat. Pflanzenfam. 3(1a): 11. 1892, nom. superfl.-LECTOTYPE: C. rigida (Torr. in Whipple) Torr. \& A. Gray, indirectly selected by Dammer, Nat. Pflanzenfam. 3(1a): 11. 1892 and confirmed here.

Plants erect, sparsely pubescent; leaves basal and cauline, the basal ones broadly elliptic to obovate, the cauline ones linear to linear-lanceolate and awn-tipped; inflorescences in dense clusters on short shoots subtended by spine-tipped and ultimately hard and thornlike cauline leaves; bracts linear, aciculate, awn-tipped; involucres urceolate, 3-angled and 3-ribbed, corrugate, the prominent anterior tooth thickened basally and often expanding, lanceolate to narrowly elliptic, spreading, awn-tipped, the two smaller ones spreading, rarely expanding apically, short awned; flowers yellow, densely pubescent; stamens 9; achenes brown, globose, the embryo curved.

A common and widespread monospecific taxon of the desert regions of western Nevada and eastern California south to northwestern México, and east into southwestern Utah and western and southern Arizona, from - $230 \mathrm{ft}$ below sea level to $6000 \mathrm{ft}$ elev; flowering from Feb-Jun.

The sect. Acanthogonum has been variously defined. Torrey and Gray (1870) included all of the species recognized here except the as yet undescribed Chorizanthe orcuttiana, a concept followed by Watson (1877) and Hooker (1880). These authors defined the section on the position of the stamen attachment. Parry (1884) restricted its circumscription to just $C$. polygonoides and $C$. rigida, basing it on a combination of faucially inserted stamens and a curved embryo. This view was followed by Goodman $(1934,1955)$ when he reestablished Acanthogonum. Dammer (1892), by including Acanthogonum and its type in his sect. Campylosperna rendered his name a potential synonym of the sect. Acanthogonum. Dammer defined his section to include all of the annual species of Chorizanthe with curved embryos, establishing a definite rank for Parry's (1884) "Group" Campylosperma. Parry had recognized 
two sections within his "Group", Chorizanthella and Acanthogonum. By typifying Campylosperma on $C$. rigida, as we have done here, we can dispose of the name without jeopardizing other sectional names.

35. Chorizanthe rigida (Torr. in Whipple) Torr. \& A. Gray, Proc. Amer. Acad. Arts 8: 198. 1870. Acanthogonum rigidum Torr. in Whipple, Pacif. Railr. Rep. Whipple, Bot. 4: 133. 1857.-TYPE: Bill Williams River, Mojave Co., Arizona, 1854, Bigelow s.n. (holotype, NY!).

Erect, densely branched, spreading pubescent annual herbs 0.2-0.8 (1.5) dm high and 0.10.7 (1) dm across; leaves basal and cauline, the basal ones broadly elliptic to obovate, the blades $0.5-2.5 \mathrm{~cm}$ long, (3) $5-20 \mathrm{~mm}$ wide, thinly pubescent on the upper surface, more densely so to tomentose below, obtuse to rounded apically, on a pubescent petiole $0.5-3(4) \mathrm{cm}$ long, the cauline ones of two kinds, the lower one at the node solitary and soon deciduous, similar to the basal leaves only mucronate, the blades $1-2(2.5) \mathrm{cm}$ long, $5-15 \mathrm{~mm}$ wide, equally pubescent on both surfaces, awn-tipped with the awns mostly 2-4 mm long, the upper cauline leaf solitary at the node and persistent, sessile, linear to linear-lanceolate and bractlike, up to $1.5 \mathrm{~cm}$ long and $0.5-1.5 \mathrm{~mm}$ wide, becoming hard and thornlike with age; inflorescences cymose, the involucres in dense clusters in the axils of the bracts, these on short shoots and each subtended by the cauline leaves; bracts 2, subopposite to opposite, linear, 5-10 (12) mm long, 1-2 $\mathrm{mm}$ wide, the awns straight, 2-4 mm long; involucres urceolate, 3-angled but 3ribbed, greenish, corrugate, the tube $2-3 \mathrm{~mm}$ long, pubescent, the teeth of two sizes, the longer anterior one thickened toward the base, sometimes expanding and becoming lanceolate to narrowly elliptic, $5-10 \mathrm{~mm}$ long, spreading, with a straight awn $1-2.5 \mathrm{~mm}$ long, the smaller two teeth $2-5 \mathrm{~mm}$ long, spreading, rarely expanding and becoming narrowly lanceolate, the straight awns $0.5-1.2 \mathrm{~mm}$ long; flowers solitary or rarely 2 , included to slightly exserted from the involucre, cylindric, $1.5-1.8 \mathrm{~mm}$ long, yellow, densely pubescent without, on slightly winged pedicels $0.2-0.4 \mathrm{~mm}$ long, the tepals monomorphic, oblong, rounded, entire, slightly spreading, united more than two-thirds of their length; stamens 9 , slightly exserted, attached to the top of the floral tube, the filaments $0.5-1 \mathrm{~mm}$ long, yellowish, glabrous, the anthers 0.2-0.3 mm long, oval, yellowish; achenes brown, globose, (1.5) 1.8-2.2 mm long; $n=$ 19, 20 (Hardham 1989).

Common and widespread in sandy to gravelly or rocky places in western Nevada and eastern California in the desert regions south to northern Baja California Norte, México, and eastward across southern Nevada to southwestern Utah and western and southern Arizona to northwestern Sonora, México, from - 200 feet below sea level to $6000 \mathrm{ft}$ elev, flowering from Feb-Jun.

Representative Specimens: MÉXICO. BAJA CALIFORNIA NORTE: Calmalli, 25 Apr 1889, Brandegee s.n. (DS, F, G, GH, MIN, NY, PH, UC, US); NE side of Cocopa Mountains, $20 \mathrm{mi}$ SE of Mexicali, 22 Apr 1949, Gentry 8759 (ARIZ, RSA); along the dirt road from Agua de Higuera to San Borja, $1.7 \mathrm{mi}$ NNE of Agua de Higuera, $21 \mathrm{Mar}$ 1988, Reveal et al. 6664 (CAS, MARY); along an arroyo $2 \mathrm{mi} \mathrm{N}$ of Las Arrastras, 24 Mar 1960, Wiggins \& Wiggins 15927 (DS, G, LE, MEXU). SONORA: $1 \mathrm{mi}$ S of México Highway 2, $4 \mathrm{mi}$ E of Los Vidrios, NE part of the Pinacate Region, 19 Mar 1970, Felger et al. 19659 (ARIZ); San Luis on the Rio Colorado, 18 Feb 1959, Miranda 8901 (MEXU); $12 \mathrm{mi} \mathrm{NW}$ of Caborca, 10 Mar 1936, Shreve 7539 (ARIZ, F, MEXU, MICH). UNITED STATES. ARIzonA: Cochise Co.: Chiricahua Mountains, Aug 1881, Lemmon s.n. (BM, G). Coconino Co.: near Porter Springs, Pima, 10 Jul 1935, Maguire 10620a (NY, UTC). Maricopa Co.: along Bush Highway, 18 mi NE of Tempe, 9 Mar 1982, Daniel \& Parfitt 2015 (ASU, MICH); S side of Salt River Mountains, 28 Mar 1932, Gillespie 5525.5 (DS, GH, NY, POM, US); along Arizona Highway 87, $4 \mathrm{mi} \mathrm{N}$ of McDowell Road junction, $10 \mathrm{mi}$ E of Scottsdale, 25 Mar 1962, Russell 62-32 (DS, PH). Mohave Co.: Beaverdam, 17 May 1971, Higgins 4185 (ASU, BRY); N edge of Seegmiller Mountain, 11.5 air mi S of St. George, 25 May 1969, N.H. Holmgren 3338 (NY, US, UTC, WTU); 
Yucca, 14 May 1884, M.E. Jones 3904 (ARIZ, BKL, BM, BR, CAS, DS, F, G, MSC, NY, POM, RM, US, UTC, WU). Pima Co.: Cabeza Prieta Game Range, 7 Apr 1979, Lehto et al. 23576 (ASU, NY, OBI); Dripping Springs, Puerto Blanco Mountains, Organ Pipe Cactus National Monument, 15 Apr 1952, Parker 7923 (ARIZ, RSA, UC, US); near Tucson, 28 Apr 1883, Pringle s.n. (BR, E, F, G, GOET, K, LE, MICH, MO, NY, PENN, PH, US, VT, WU). Pinal Co.: 2 mi E of Apache Junction, 14 mi E of Mesa, 26 Mar 1960, Russell 11295 (MICH, OSC, SMU, WIS); near U.S. Department of Agriculture Station in Gila River Valley near Sacaton, 24 Apr 1930, Wolff \& Dana 1833 (MSC, SMU, US). Yavapai Co.: E end of Harcuvar Mountains, 13 May 1982, P. Schneider s.n. (UCR). Yuma Co.: S of the Gila River below Wellton, 31 Mar 1932, Fosberg 7485 (F, LA, NO, PENN); base of Telegraph Pass, 13 mi E of Yuma, Liguerta Mountains, 2 Mar 1958, C.T. Mason 1656 (ARIZ, CAS, DAO, UT); Gila Crossover below Imperial Dam, 15 Feb 1945, McMurry \& Phillips 2659 (ARIZ, NY, UC); Wayside Inn, W of Brown's Crossing, 10 Mar 1973, Pinkava \& McLeod 10316 (ASU, NY, US). CALIFORnIA: Imperial Co.: 0.5 mi N of U.S. Highway 80 on road to Blythe, 20 Mar 1958, Balls \& Everett 22897 (BM, RM, RSA); 8 mi N of Winterhaven, 18 Mar 1970 , C.L. Hitchcock 25692 (DAO, ID, G, NY, OKL, TEX, UT, WTU); $5 \mathrm{mi}$ N of Potholes, 13 Apr 1932, Johansen \& Ewan 7140 (BM, NO, TEX); Dos Palmas, 30 Mar 1922, Spencer 2147 (F, GH, MIN, PH). Inyo Co.: between Stovepipe Wells and Scotty's Castle, Death Valley National Monument, Jan 1931, Bryant 1828 (DS, RSA, UC); Silver Canyon, 1 Jun 1933, Duran 3454 (ARIZ, BM, DAO, DS, E, G, GH, LE, MO, NY, PENN, RSA, SD, TEX, UC, UTC); Death Valley, foot of Grapevine Mountains, near fork of Beatty Road, 16 Mar 1973, Holmgren \& Holmgren 6325 (BRY, ID, NY, UTC); $1.7 \mathrm{mi}$ NE of Poleta Mine, $3.3 \mathrm{mi}$ ESE of Laws, White Mountains, $12 \mathrm{Apr}$ 1986, Morefield \& McCarty 3405 (MARY, MO, RSA, UCR); Jubilee Pass, S end of Black Mountain, 6 Mar 1937, Train s.n. (ARIZ, COLO, DS, ILL, NEB, RSA, US). Kern Co.: plains at S base of Galileo Hill, 26 Apr 1966, Twisselmann 12009 (CAS, OSC, SBBG). Mono Co.: Chalfant Valley, along U.S. Highway 6, 18.5 mi S of Benton, 11 Jun 1976, Halse 1377 (DS, OSC). Riverside Co.: Deep Canyon, Coachella Valley, 14 Mar 1932, Munz 11998 (MO, MONTU, POM, UC); E side of Salton Sea, $1 \mathrm{mi} \mathrm{N}$ of Imperial County line, 24 Mar 1941, Wiggins 9583 (DS, GH, RM, RSA, UC, WTU); W edge of Maria Mountains, 17 mi from Blythe on Rice Road, 29 Apr 1932, Wolf 3094 (DS, RSA, SD, WTU). San Bernardino Co.: Poison (Salt Wells) Canyon, SW of Trona, 17 Apr 1940, Alexander \& Kellogg 1124 (DS, GH, NY, OKL, UC, UTC); 0.2 mi up the canyon from the spring, Sheep Springs Canyon, 24 Mar 1964, Hitchcock \& Muhlick 23295 (F, G, HSC, RM, UC, UT, WTU); Needles, 10 May 1884, M.E. Jones 5175 (BM, BR, CAS, DS, F, G, MIN, MSC, POM, US, UTC); Mojave Desert, May 1882, Parish \& Parish 229 (BR, G, ISC, LE, MPU, UC, US, WU); 28 mi SW of Amboy, 1 May 1949, Solheim \& Solheim 2551 (GH, OKL, RM, TEX); 8 mi SW of Bicycle Lake, 28 Apr 1935, Wolf 6530 (ARIZ, BRY, RM, RSA, WS); 8 mi N of Denning Springs, $6.4 \mathrm{mi}$ from the Amargosa River, 30 Apr 1935, Wolf 6611 (ARIZ, NY, OKL, RSA, WTU). San Diego Co.: Signal Mountain, 2 Apr 1903, Abrams 3172 (DS, GH, MIN, NY, POM); Colorado Desert, Apr 1889, Orcutt s.n. (B, MIN, MO, POM, US). NevadA Churchill Co.: E side of Black Butte, N of Hazen, 18 May 1980, Tiehm 5605 (CAS, MO, NY, RSA, UTC); SE side of the Desert Mountains, SW of the Rawhide turnoff from U.S. Highway 95 S of Fallon, 22 May 1980, Tiehm \& Birdsey 5690 (CAS, NESH, NY, UTC). Clark Co.: Kane Wash along U.S. Highway 93, $35 \mathrm{mi}$ NW of Glendale, 4 May 1952, RJ. Davis 5012 (IDS, WS, WTU); Moapa, 8 Apr 1905, Goodding 2197 (CM, E, GH, MIN, MO, NMC, NY, RM, UC); 6 mi NW of Indian Springs, 13 May 1937, C.L. Hitchcock 3100 (GH, MONTU, UC, WTU); Juanita Springs Ranch, $10 \mathrm{mi}$ S of Riverside, 16 Apr 1960, Tavares 503 (DAO, RM, UC, UTC). Esmeralda Co.: Gold Mountain, May-Oct 1898, Purpus 6010 (E, K, MIN, NY, SD, UC, US). Humboldt Co.: SE side of the Black Rock Range, 31 May 1983, Tiehm 7792 (CAS, NY). Lincoln Co.: $\mathrm{N}$ bajada of East Desert Range along road to Cabin Spring in Desert Valley, 12 May 1983, Ackerman 83-423b (UNLV); Pahranagat Valley, Hiko Range, 6 mi N of Hiko, 6 Jun 1980, Thorne \& Harrison 1008 (BRY, NY). Lyon Co.: Singatse Range, Ludwig, on the W side of the range, 10 Jun 1981, Tiehm 5881 (CAS, MO, NY, UTC). Mineral Co.: Candelaria, 1883, Shockley 329 (DS). Nye Co.: Steves Pass at the S end of Bare Mountain W of Crater Flat, 30 May 1980, Ertter \& Strachan 3569 (BRY, CAS, MARY, NESH, NY, UTC); Ash Meadows, 5 mi E of Highway 127 on road to Ash Meadows Ranch, 1 May 1970, Reveal \& Henderson 2163 (NTS, RENO, RSA); 2.9 mi S of U.S. Highway 95 along Nevada Highway 16, 4 Apr 1978, M.J. Williams 78-12-4 (BRY, NESH, NY). Washoe Co.: SE of Winnemucca Lake, mine area NW of Black Warrior Peak, 2 May 1978, Tiehm 4066 (CAS, MARY, MO, NY, RENO, RSA, UNLV, UTC). UTAH: Washington Co.: St. George, 4 Apr 1931, Cottam 5652 (BRY, MIN, UT); E slope of Black Hill, St. George, 13 Apr 1942, Gould 1543 (ARIZ, NY, OKL, UC); St. George, 1875, Palmer s.n. (BM, E, F, G, LE, NY); Terry's Ranch, Beaverdam Wash, 3 May 1966, Welsh 5281 (BRY, ISC). A total of 728 collections are known to us.

Chorizanthe rigida (from the Latin rigidis, stiff, inflexible, alluding to the rigid secondary leaves) is certainly one of the most distinctive species of the genus and for avid collectors of late spring and early summer desert annuals one of the most painful. The exceedingly compact and dense inflorescence with its suppressed secondary branches has left a plant composed 
of a series of leaves and bracts subtending a closely arranged series of bracteated and involucrated flowers. The narrow upper cauline, awn-tipped leaves dry and hardened as the plant passes from full anthesis to fruit producing an individual fully as spinose as any cactus. This function probably has a dual role. First, it is an obvious protective measure in an area where grazing animals are the rule. Second, as any field botanist can testify, the mature plants will easily break off their root stock and will adhere to clothing so that the fruit-rich plants can be carried away from their original síte.

IVB(3). Chorizanthe R. Br. ex Benth. subsect. Exolophyta Rev. \& Hardham, subsect. nov.TYPE: Chorizanthe orcuttiana C. Parry.

A subsect. Acanthogono plantis prostratis cum involucralis aristis uncinatis et embryoibus rectis differt.

Plants prostrate, villous annual herbs; leaves basal and cauline, the basal ones narrowly oblanceolate, the cauline ones oblanceolate and awnless; inflorescences cymose, in small clusters; bracts linear, aciculate, awn-tipped; involucres campanulate, 3-angled and 3-ribbed, faintly corrugate, the three teeth about equal sized, spreading, the awns uncinate; flowers yellow, densely pubescent; stamens 9; achenes dark brown, narrow, the embryo straight.

A rare, local and probably extinct monospecific taxon of coastal mesas and hills in San Diego Co., California, from Point Loma to near Del Mar, from 200-400 ft elev; flowering from Mar-May.

The subsect. Exolophyta (from the Greek exoles, utterly destroyed, ruined, and phyton, plant, alluding to the fact that this species is probably extinct due to habitat destruction) is established for a single species, Chorizanthe orcuttiana (proposed to honor Charles Russell Orcutt, 1864-1929, a professional natural history collector in San Diego and editor of The WestAmerican Scientist), that is now probably extinct. Repeated efforts by numerous excellent field botanists associated with various endangered and threatened species programs have attempted to rediscover the species but to no avail.

The species bears a strong resemblance to Chorizanthe procumbens and especially the jonesiana expression. That plant has a broadly campanulate involucre but with six teeth and a reduction to three teeth by suppression of the minor teeth is not difficult to imagine. Also, it has a yellow, densely pubescent flower, and as is seen in the chaetophora expression of $C$. procumbens, $C$. orcuttiana has a grayish cast to its pubescence. The placement of the stamens on the upper portion of the floral tube is unlike the case found in $C$. procumbens. In that species the filaments are united into a pilose-ciliate staminal tube that is not attached to the short floral tube. Again, the evolution of a flower with the staminal tube adhering to an elongated floral tube is not hard to imagine.

If there was a plant that might have come about as the result of hybridization involving a species similar to Chorizanthe procumbens and one close to $C$. polygonoides, that product would not be unlike $C$. orcuttiana. Significantly, $C$. orcuttiana is a octoploid $(n=40)$ and both of the above mentioned species are tetraploids $(n=20)$. At some of the historical sites where $C$. orcuttiana was found, both of the tetraploids were found in the general area.

In the field, Hardham found Chorizanthe orcuttiana to be nearly always half-buried in soft sand while $C$. procumbens and $C$. polygonoides were restricted to the more gravelly sites or where the sand was more firm.

We are not suggesting that Chorizanthe orcuttiana is a hybrid between $C$. procumbens and $C$. polygonoides for we have not demonstrated that. Until an extant population of $C$. orcuttiana can be located and the biology of the species investigated in detail, we can not resolve the 
problem. We must state, however, that $C$. orcuttiana is certainly a good species and even without actual studies to document the point, we are certain it is an alloautopolyploid and not a simple $F_{1}$ hybrid.

36. Chorizanthe orcuttiana C. Parry, Proc. Davenport Acad. Nat. Sci. 4: 54. 1884.-TYPE: sandy soil on Point Loma, San Diego Co., California, 12 Mar 1884, Orcutt s.n. (holotype, ISC!; isotypes: ISC, PH, UC!).

Prostrate, villous annual herbs 0.1-0.5 dm high and 0.3-2 (2.5) dm across; leaves basal, the basal ones narrowly oblanceolate, the blades $0.5-1.5 \mathrm{~cm}$ long, 2-3.5 (5) $\mathrm{mm}$ wide, thinly pubescent on both surfaces, acute apically, on a pubescent petiole $1-2 \mathrm{~cm}$ long; inflorescences cymose, the involucres in small clusters $0.5-1 \mathrm{~cm}$ across; bracts 2 , opposite, often of two types, the laminar one essentially similar to the basal leaves, oblanceolate, $0.3-1 \mathrm{~cm}$ long, $1-3 \mathrm{~mm}$ wide, awnless, this opposite a greatly reduced, linear, 1-2 mm long, 0.3-0.6 mm wide, acicular bract terminate by a short, straight, 0.6-1 mm long; involucres campanulate, 3-angled but 3-ribbed, greenish, faintly corrugate, the tube 1.8-2 $\mathrm{mm}$ long, pubescent, the three teeth all of one size, prominent and thickened toward the base, 1.8-2 mm long, spreading, with uncinate awns $0.6-1 \mathrm{~mm}$ long; flowers included to slightly exserted from the involucre, cylindric, 1.5-1.8 mm long, yellow, densely pubescent without, on pedicels $0.8-1.1 \mathrm{~mm}$ long, the tepals monomorphic, narrowly oblanceolate, obtuse to truncate, entire, slightly spreading, 9 , slightly exserted, attached to the top of the floral tube, the filaments $0.5-0.8 \mathrm{~mm}$ long, yellowish, glabrous, the anthers $0.2-0.3 \mathrm{~mm}$ long, oval, reddish; achenes dark brown, narrow, $2-2.2 \mathrm{~mm}$ long; $n=(38-39) 40$ (42) (Hardham 1989).

Historically rare, local and now probably extinct in loose sandy soil on mesas and hills near the coast from Point Loma northward to near Del Mar, San Diego Co., California, from 200-400 feet ft elev; flowering from Mar-May.

Specimens Examined: UNITED STATES. CALfFoRnLA: San Diego Co.: Point Loma, 25 Apr 1897, Brandegee s.n. (MIN, NY, ORE, POM); Point Loma, 25 Apr 1897, Brandegee \& Cleveland s.n. (UC); Point Loma, 28 Apr 1905, Brandegee s.n. (POM, SD); San Diego, May 1906, Brandegee s.n. (BKL, NY); Point Loma, 28 Apr 1905, K. Brandegee s.n. (DS, RM, US); Point Loma, on hill NE from Brotherhood Grounds, 28 Apr 1905, K. Brandegee s.n. (UC); Point Loma, 10 Apr 1906, K. Brandegee 218 (ARIZ, B, BM, BR, CAS, DS, E, F, G, GH, K, LA, LE, MO, MPU, NY, ORE, POM, RM, UC, US, WIS, Z); Point Loma, $10 \mathrm{Apr}$ 1906, K. Brandegee s.n. (POM); Point Loma, 17 Mar 1883, Cleveland s.n. (SD); lighthouse, San Diego, Mar 1884, Cleveland s.n. (DS); San Diego, Mar 1884, Cleveland s.n. (CAS); Point Loma, 13 Mar 1884, Cleveland s.n. (F); near Mussel Beach, 12 Mar 1884, Cleveland \& Orcutt s.n. (SD); Point Loma, near building, Apr 1884, Cleveland \& Orcutt s.n. (UC); Kearney Mesa, 13 Mar 1935, Gander 140.11 (SD); 2.5 mi E of Encinitas on road to Olivenhain, 4 May 1938, Gander 5479 (OKL, RM, SD); Del Mar, 4 Apr 1962, Hardham 8941 (CAS, DAO, RSA, SD, SBBG); Point Loma, 4 Apr 1962, Hardham 8945 (CAS, DAO, RSA, SBBG, SD); near intersection of Balour Drive and Encinitas Boulevard, Encinitas, 7 Apr 1978, Oberbauer s.n. (SD); San Diego, Mar 1884, Orcutt s.n. (BM); San Diego, 24 Mar 1884, Orcutt s.n. (MICH); Point Loma, 21 Apr 1884, Orcutt s.n. (CAS, CM, F, NY, US, VT); San Diego, Apr 1884, Orcutt s.n. (F, G, GH, K, MO, NY, ORE); mesa at Point Loma, 2 Apr 1884, Orcutt s.n. (ISC); Point Loma, 28 Mar 1914, Parish 9111 (DS, JEPS); without location data, 1881, Parry s.n. (MO); Point Loma, May-Oct 1898, Purpus s.n. (UC); without location data, without data, Unknown s.n. (MIN).

IVB(4). Chorizanthe R. Br. ex Benth. subsect. Ansata Rev. \& Hardham, subsect. nov. - TYPE: Chorizanthe watsonii Torr. \& A. Gray.

A subsect. Acanthogono involucris cylindricis et quinque lobatis cum unico ligulatis differt.

Plants spreading to erect, densely canescent-strigose annual herbs; leaves basal or nearly so, oblanceolate; inflorescences cymose, in small clusters; bracts laminar and oblanceolate below, reduced and linear above, aciculate, awn-tipped; involucres cylindric, 3-angled and 
5-ribbed, faintly corrugate, the anterior tooth prominent, leaflike, thickened toward the base and lanceolate, the remaining four small, linear and erect, the awns uncinate; flowers yellow, thinly pubescent; stamens 9 ; achenes brown, narrow, the embryo straight.

Local and common in sandy to gravelly places in the western United States from southeastern Washington and southwestern Idaho southward through Oregon; eastern California and Nevada to southwestern Utah and northwestern Arizona, and into southern California as far south as Riverside Co. and as far west as San Luis Obispo and Santa Barbara cos., from 1000-7800 ft elev, flowering from Apr-Aug.

The subsect. Ansata (from the Latin, ansatus, having a handle, alluding to the long and expanded anterior lobe), and its only species Chorizanthe watsonii, is one of two northern expressions of the sect. Acanthogonum that can be found mainly in the cold desert and sagebrush scrub of the Great Basin. It follows the arid grasslands across from the south end of the Sierra Nevada through the Tehachapi Mountains and the Transverse Ranges to the southern part of the inner Coast Range. To the north, the species seems to have also followed the grassland, entering onto the Palouse Prairie in eastern Washington and adjacent Idaho. To the south, as at the east end of the San Bernardino Mountains and on the foothills of the San Jacinto Mountains in Riverside Co., California, the species is widely scattered. The modern distribution pattern of $C$. watsonii indicates that it migrated northward into its present range during late Pleistocene and early Holocene times. The species followed the northwardly expanding cold desert flora, extending itself in the grasslands both to the north and east. Its less hardy relatives in the sect. Acanthogonum either remained in place in the chaparral or were restricted to the warmer and more southerly deserts.

37. Chorizanthe watsonii Torr. \& A. Gray, Proc. Amer. Acad. Arts 8: 199. 1870.-TYPE: Humboldt Mountains, Pershing Co., Nevada, 1865, Torrey 435. (lectotype, NY!, selected by Ertter \& Tiehm, Brittonia 35: 29. 1983; duplicate of the lectotype: GH!).

Spreading to erect, rather densely canescent-strigose annual herbs $0.2-1(1.5) \mathrm{dm}$ high and across; leaves basal or nearly so, the blades oblanceolate, (0.3) $0.5-1.5$ (2) cm long, $2-4$ (5) $\mathrm{mm}$ wide, thinly floccose to sparsely tomentose on the upper surface, more densely so below, acute apically, on a pubescent petiole (0.5) 1-2.5 (3) $\mathrm{cm}$ long; inflorescences cymose, the involucres in small clusters $0.5-1 \mathrm{~cm}$ across, otherwise solitary; bracts 2 , opposite, the laminar ones oblanceolate, (5) 8-15 (20) mm long, (1) 2-4 mm wide, linear-lanceolate, becoming reduced above and scalelike, acicular, the slightly curved awns $0.5-1 \mathrm{~mm}$ long; involucres cylindric, 3-angled but 5-ribbed, green, finely corrugate, the tube 3-4.5 mm long, pubescent, the anterior tooth thickened toward the base, 2-6 mm long, narrowly lanceolate, erect, with an uncinate awn 0.6-1 mm long, the remaining four teeth 1-2 mm long, linear, erect, with uncinate awns 0.4-0.8 (1) mm long; flowers included to slightly exserted from the involucre, cylindric, $1.5-2.5 \mathrm{~mm}$ long, yellow, thinly pubescent without, on pedicels $1.5-2.5 \mathrm{~mm}$ long, the tepals monomorphic, oblong, acute, entire, united about two-thirds of their length; stamens 9 , slightly exserted, attached to the top of the floral tube, the filaments $0.8-1 \mathrm{~mm}$ long, white, glabrous, the anthers $0.2-0.3 \mathrm{~mm}$ long, oval, yellow; achenes brown, narrow, 2.5-3 mm long.

Local and common in sandy to gravelly places in the grasslands and sagebrush scrub, often extending to the margins of conifer woodlands, from southeastern Washington and adjacent southwestern Idaho south through central and eastern Oregon, eastern California and Nevada to Washington Co., Utah, Mohave Co., Arizona, and in scattered locations in Riverside Co., California, then westward along the northern edge of the San Bernardino and San Gabriel mountains to the Santa Ynez Mountains of Santa Barbara Co. and onto the inner Coast Ranges in San Luis Obispo Co., from 1000-7800 feet ft elev, flowering from Apr-Aug. 
Specimens Examined: UNITED STATES. ARIzona: Mohave Co.: Chloride, 14 Apr 1903, M.E. Jones s.n. (POM). CAlifornia: Inyo Co.: Westgard Pass, White Mountains, 27 Jun 1930, Duran 517 (ARIZ, B, BM, BR, BRY, CAS, DAV, DS, E, F, G, GH, K, LA, LE, MIN, MO, NO, NY, ORE, RM, RSA, SD, UC, US, UTC, WIS, Z); Wildrose Canyon, Panamint Mountains, Death Valley National Monument, 3 Jun 1937, Gilman 2577 (POM); China Lake Naval Weapons Center, at Coso Hot Springs, 22 Apr 1978, Zembal 428 (RSA). Kern Co.: Mojave, 13 May 1913 , Eastwood 3235 (CAS, GH, UC, US); Cuddy Valley, near Mt. Pinos, Jun 1905, H.M. Hall 6355 (UC); N shore of Lake Isabella, 21 May 1962, Rose 62033 (BRY, CAS, RSA); Tejon Ranch, meadow near summit of the SW end of Catskin Basin, head of Spanish Needle Creek, 3 Jun 1965, Twisselmann 10918 (CAS, RSA, SBBG). Lassen Co. Baxter Creek, S of Susanville, 17 Jun 1961, Hardham 7499 (CAS, SBBG, UCSB). Los Angeles Co.: between Palmdale and Littlerock, 5 May 1947, Howe 1596 (SD); 2.5 mi S of Llano, San Gabriel Mountains, 11 May 1973 , Thorne 43467 (DS, NY, RSA). Mono Co.: 1.5 mi below mouth of Pellisier Creek near road, $1.5 \mathrm{mi}$ SW of Mt. View and Proctor Mine, White Mountains, 19 Apr 1986, Morefield \& McCarty $3+56$ (BRY, MARY, MO, RSA, TEX, UCR); lower end of Twin Lakes, W of Bridgeport, 3 Aug 1945, Wiggins \& Rollins 521 (CAS, DS, GH, MICH, RSA, UC, UTC, WTU). Riverside Co.: Agua Caliente, Apr 1882, Parish \& Parish 1201 (BM, BR, DS, F, G, ISC, MIN, MO, NY, PH, US, WU); along Whitewater River, $3.2 \mathrm{mi} \mathrm{N}$ of Whitewater Post Office, 28 May 1980, Thorne \& Tilforth 54225 (RSA). San Bernardino Co.: 7 mi S of Box "S" Ranch, 9 Jun 1932, Munz \& Hitchcock 12776 (F, MIN, MONTU, POM); hills bordering the Mojave Desert, 25 May 1882, Pringle s.n. (CAS, E, F, G, GH, K, LE, MIN, MPU, NY, PENN, PH, US, VT, WU); W of Big Bear City, San Bernardino Mountains, 14 Jun 1979, Thorne et al. 53050 (BRY, MARY, NY, RSA). San Luis Obispo Co.: between San Juan River and Carrisa Plain, 6 May 1950, Hoover 7889 (CAS, DS, OBI, OKL, UC). Santa Barbara Co.: along the Ballinger Canyon Road, $0.5 \mathrm{mi}$ E of California Highway 33, 24 May 1988, Reveal 6891 (CAS, MARY, RSA). Tulare Co.: 1.5 mi E of Johnsondale, 22 May 1962, J. T. Howell 37384 (CAS, DAV); San Hill Ridge, along U.S. Forest Service Road 22S82, 5 Jun 1972 , Shevock 1912 (CAS). Ventura Co.: 2.2 mi SW of Gorman, 1 Jun 1978, Gustafson 962 (RSA); 3.6 mi S of Pine Mountain Summit along California Highway 33, 4 Jun 1965, Keefe 944 (UCSB). IDAHO: Ada Co.: 2 mi S of Regina, 18 Jun 1943, Christ 14116 (NY). Bingham Co.: near Middle Butte, $2.5 \mathrm{mi}$ E of Idaho Highway 26 on T-4, Idaho National Engineering Laboratory, 18 Jun 1982, Cholewa 987 (ID). Blaine Co.: 1 mi NNE of Picabo, 12 Jun 1980, Packard \& Grimes 80-86 (NY). Butte Co.: S side of Cedar Butte, S of Atomic City, 10 Jun 1980, Grimes et al. 1628 (NY, WTU). Camas Co.: 0.2 mi SE of Divide Reservoir, Mt. Bennett Hills, 20 Jul 1978, Ertter 2400 (NY). Canyon Co.: Big Willow, 31 May 1910, Macbride 159 (CM, E, G, GH, ILL, MIN, MO, NEB, RM, US). Elmore Co.: Rattlesnake Creek, near Dixie, 24 Jun 1916, Macbride \& Payson 2848 (GH, MO, RM, US). Gooding Co.: along a dirt road 3.5 air mi NE of Bliss, 18 Jun 1975, Beveridge \& Ertter 75-13 (ID); City of Rocks, 25 mi NW of Gooding, 14 Jun 1941, Christ 12361 (ID, NY). Lincoln Co.: Shoshone, 10 Jun 1893, Palmer 128 (BKL, CAS, CGE, F, GH, MO, NY, PH, RM, UC, US, Z). Owyhee Co.: 5 mi S of Grasmere, 21 Jun 1956, W.H. Baket 14053 (ID, WTU); Three Creek, 2 Jul 1912, Macbride \& Payson 1875 (E, GH, ID, MIN, RM, US, WS). Twin Falls Co.: Roseworth Reservoir, 26 Jun 1937, Christ \& Ward 8022 (ID, NY). Washington Co.: Weiser, 7 Jul 1899, M.E. Jones s.n. (POM). NevadA: Carson City Co.: Eagle Valley, 15 Jun 1902, C.F. Baker 1092 (G, GH, MO, NDG, NY, POM, US). Douglas Co.: 0.5 mi E of Slater's Mine, Pine Nut Range, 10 Jul 1983, Williams et al. 83-90-3 (BRY, CAS, NESH, NY, UTC). Elko Co.: intersection of the Sunflower Flat Road and the highway at Wildhorse Reservoir, 26 Jun 1981, Grimes et al. 2154 (ASU, BRY, CAS, NY, WTU); SE foothills of the Independence Mountains, $1.2 \mathrm{mi}$ W of Dinner Station, 11 Jun 1972, Holmgren \& Holmgren 5861 (BRY, ID, MONTU, NY, UTC, WTU); Horse Creek, $2.5 \mathrm{mi}$ E of the Jackpot Road on the road from Rock Springs to Goose Creek, 31 May 1986, Tiehm \& Williams 10535 (ID, NY, ORE, RM, RSA). Esmeralda Co.: Candelaria, without date, Shockley 291 (NDG). Eureka Co.: 2 mi N of Beowawe, 10 Jun 1941, A.H. Holmgren 1038 (DAO, GH, MO, NY, RM, UC, UTC, WS); Carlin Canyon, 1.8 air mi NW of Palisade, 18 Jun 1979, Tiehm \& Birdsey 5037 (BRY, MO, NY, RSA, UTC). Humboldt Co.: Singas Creek, Santa Rosa Range, NE of Winnemucca, 22 Jun 1967, Gentry \& Davidse 1605 (ARIZ, ASU, BRY, COLO, DAO, DS, GH, ILL, ISC, MIN, NY, OSC, RM, RSA, TEX, UC, UTC, W, WS, WTU); W side of Sugarloaf Hill, Martin Creek drainage, 2 Jul 1978, Grimes \& Packard 1216 (ASU, COLO, MO, NY, OSC, RENO, UC, UT, UTC, WTU); Pine Forest Range, $11 \mathrm{mi} \mathrm{N}$ of Leonard Creek Ranch, 1 Jul 1964, Holmgren \& Reveal 1234 (DAO, GH, NY, TEX, UTC, WS, WTU); Calico Mountains, wash at NE end of High Rock Lake, 25 May 1982, Tiehm \& Williams 7015 (CAS, MO, NY, RM, RSA, UTC). Lander Co.: Reese River Valley, near the mouth of Veatch Canyon, 27 Jun 1978, Goodrich 11591 (BRY, RM, UTC). Lincoln Co.: Newman Canyon along U.S. Highway 93 W of Caliente near the roadside rest, 25 May 1980, Tiehm \& Williams 5712 (CAS, NESH, NY, UTC); Clover Mountains, 6.2 mi from Caliente on the Ella Mountain Road, 23 Jun 1983, Tiehm \& Williams 7972 (BRY, CAS, CM, COLO, DAO, IDS, MIN, NEB, NESH, NY, RSA, UTC, WTU). Lyon Co.: above Desert Creek, Sweetwater Mountains, 5 Jun 1986, Breedlove et al. 62640 (CAS); 0.5 mi W of Nevada Highway 22 on Risue Road., 21 Jun 1978, Pinzl 1868 (NY). Mineral Co.: Miller Mountain, 22 Jun 1882, Shockley 291 (JEPS). Nye Co.: Mid Valley, 19 May 1966, Beatley 3702 (DS, NTS, RENO, UNLV); Indian Valley, $16 \mathrm{mi}$ S of the Reese River Ranger Station, 7 Jul 1945, Maguire \& Holmgren 25675 (GH, NY, UC, UTC); N end of Shoshone Mountain at the drainage divide 
on Buckboard Mesa Road, 4 Jun 1968, Reveal 1121 (DS, NTS, NY, RENO); 3.5 mi N of U.S. Highway 6 along the Salsberry Wash Road at the S end of the Toquima Range, 27 May 1978, M.J. Williams 78-63-5 (MARY, NY, RENO). Pershing Co.: N end of the Trinity Range along the road to Sulphur, 28 Jun 1980, Tiehm 6123 (CAS, NY, RSA, UTC). Storey Co.: Virginia Range, Six Mile Canyon E of Virginia City, 13 May 1979, Tiehm \& Larson 4838 (NY, UTC); Long Valley Creek, S of Lockwood, 12 May 1978, M.J. Williamis 78-42-5 (MARY, NY, RENO, UNLV). Washoe Co.: along Nevada Highway 81, $1.5 \mathrm{mi} \mathrm{S}$ of pass, 20 air mi NW of Gerlach, 9 Jul 1980, Holmgren \& Holmgren 9580 (BRY, NY, RM); Empire City, 19 Jun 1882, M.E. Jones 2995 (BM, BR, CAS, DS, LE, MIN, MO, MSC, NO, NY, OKL, PH, POM, RM, UC, US, W); $2.2 \mathrm{mi} \mathrm{N}$ of Indian Springs on road to Massacre Lakes, 23 Jun 1984, Tiehm et al. 8759 (BRY, NY, ORE, RM, RSA, UTC, WTU). White Pine Co.: Egan Range, Robinson Summit along U.S. Highway 50, 14 Jul 1983, Pinzl 5478 (NY). OrEGON: Baker Co.: near Willow Creek, 17 Jun _- Cusick 1974,(E, F, G, K, MIN, MO, MSC, NDG, UC, US); between Huntington and Lime, 19 Jun 1932, Wann 4636 (UTC). Crook Co.: 5 mi S of Redmond, 19 Jun 1925, M.E. Peck 13847 (PH, WILLU). Harney Co.: E side of Trout Creek Mountains, $3.2 \mathrm{mi} \mathrm{W}$ of Little Wildhorse Creek road, 2 Jul 1981, Ertter 4355 (BRY, CAS, NY, RSA, TEX, UTC, WTU); base of Stein's Mountain, 30 May 1885, Howell s.n. (BM, BR, CAN, F, G, LE, MIN, NY, ORE, OSC, PH, US, WS, WTU, WU). Lake Co.: Corral Creek Reservoir E of Warner Peak, Hart Mountain National Antelope Refuge, 5 Jul 1981, Erter 4400 (NY, UTC); $32 \mathrm{mi}$ E of Christmas Valley on road to U.S. Highway 395, 1 Jul 1984, Wright \& Gross 1751 (OSC). Malheur Co.: 3 mi W of Harper, 7 Jun 1959, Cronquist 8350 (CAS, DAO, DS, GH, ID, ILL, MICH, MIN, NY, OKL, RM, RSA, SMU, TEX, UC, UTC, VT, WS); Malheur Valley, near Harper Ranch, 8 Jun 1896, Leiberg 2225 (BR, CAS, GH, NY, OKL, ORE, UC, US); UTAH: Washington Co.: Lytle Ranch, Beaverdam Wash, 31 May 1985, Higgins 15535 (BRY). WASHINGTON: Douglas Co.: Wilson Creek, Jun 1893, Sandberg \& Leiberg s.n. (BKL, ILL, ISC, MIN, NY, MO, POM, UC, WIS); junction of Crab Creek and Wilson Creek, 21 Jun 1893, Sandberg \& Leiberg 258 (B, BR, GH, K, L, LE, NY). Franklin Co.: Pasco, 25 May 1899, C.V. Piper 2960 (GH, NY, US, WS, Z). Grant Co.: $6.5 \mathrm{mi} \mathrm{N}$ of the E end of Vantage Bridge, 15 May 1980, Naas \& Naas 4017 (WS). Yakima Co.: near Morgan's Ferry, Yakima River, 8 Jun 1884, Suksdorf 445 (GH, WS). A total of 361 collections are known to us.

As reported by Ertter and Tiehm (1983), Gray had before him a variety of specimens when he (as Torrey \& A. Gray) proposed Chorizanthe watsonii (Sereno Watson, 1826-1892, early Great Basin collector and later curator at the Gray Herbarium at Harvard University) in 1870. Unfortunately, Ertter and Tiehm selected as a lectotype the one specimen Gray likely never saw, a Torrey specimen now at NY. Gray, who described this species without the aid of his long-time collaborator, received from Torrey a series of fragments from specimens in his possession, most notably portions of Torrey 435 and Stretch s.n.. There is no evidence that Gray actually examined the sheet although he did provide it with an annotation.

What Gray had in his possession was a series of specimens gathered by Sereno Watson to which he assigned a single number, 1046. These Gray labelled and distributed, sending specimens from different locations to different individuals or herbaria. The current location of these specimens was listed by Ertter and Tiehm (1983). A specimen at BM which they did not see is without location and date and therefore cannot be associated with any one collection site.

Ertter and Tiehm (1983) argued that because the Torrey specimen was in fruit, and fruiting characters were described, that the lectotype ought to be that specimen. They acknowledged that the Watson collection from Humboldt Lake would have been a reasonable choice, and had we had the opportunity to make a selection, this would have been our choice.

IVB(5). Chorizanthe R. Br. ex Benth. subsect. Chorizanthella (C. Parry) Rev. \& Hardham, comb. et stat. nov. Chorizanthe sect. Chorizanthella C. Parry, Proc. Davenport Acad. Nat. Sci. 4: 53. 1884.-LeCTOTYPE: Chorizanthe corrugata (Torr. in Blake) Torr. \& A. Gray, selected here.

Plants erect, thin tomentose annual herbs; leaves basal or nearly so, round-ovate; inflorescences cymose, in small clusters; bracts linear to linear-lanceolate and aciculate, awn-tipped; 
involucres cylindric, 3-angled and 3-ribbed, distinctly transverse corrugate, the three teeth lanceolate, all equal sized, spreading, the awns uncinate; flowers white, thinly pubescent; stamens 6; achenes brown, narrow, the embryo straight.

Local and common in sandy to gravelly places in the Mojave and Sonoran deserts of southeastern California and southern Nevada southward through western Arizona to northwestern México, from $-230 \mathrm{ft}$ below sea level to $3000 \mathrm{ft}$ elev; flowering from Feb-May.

The subsect. Chorizanthella (the genus Chorizanthe and the Latin diminutive -ella, little, alluding to a small portion of the genus) is restricted to a single species, Chorizanthe corrugata.

38. Chorizanthe corrugata (Torr. in Blake) Torr. \& A. Gray, Proc. Amer. Acad. Arts 8: 198. 1870. Acanthogonum corrugatum Torr. in Blake, Pacif. Railr. Rep. Blake, Bot. 5: 354. 1857. - TYPE: near Fort Yuma, Yuma Co., Arizona, Dec 1853, Thomas s.n. (holotype, NY!).

Erect, thinly tomentose annual herbs 0.3-1.5 dm high and 0.3-1 dm across; leaves basal or nearly so, the blades round-ovate, (0.5) 0.8-1.5 (2) cm long, (3) $5-15$ (20) mm wide, thinly floccose to tomentose on the upper surface, more densely so to tomentose below, obtuse to rounded apically, on a pubescent petiole 0.5-2 (3) $\mathrm{cm}$ long; inflorescences cymose, the involucres in small clusters $0.5-1 \mathrm{~cm}$ across, otherwise solitary; bracts 2 , opposite, linear to linear-lanceolate, $2-7 \mathrm{~mm}$ long, $1-2.5 \mathrm{~mm}$ wide, acicular, the slightly curved awns $0.5-1 \mathrm{~mm}$ long; involucres cylindric, 3-angled but 3-ribbed, green to tan, markedly transverse corrugate, the tube 3-4 $\mathrm{mm}$ long, glabrate, the three teeth all of one size, prominent and thickened toward the base, $2-4.5 \mathrm{~mm}$ long, often lanceolate, spreading, with uncinate awns $0.6-1 \mathrm{~mm}$ long; flowers included to slightly exserted from the involucre, cylindric, $2-2.5 \mathrm{~mm}$ long, white, thinly pubescent without, on pedicels $0.8-1.1 \mathrm{~mm}$ long, the tepals monomorphic, oblong, acute, entire, the outer ones slightly longer than the inner, united about two-thirds of their length; stamens 6 , slightly exserted, attached to the top of the floral tube, the filaments $0.8-1 \mathrm{~mm}$ long, white, glabrous, the anthers 0.4-0.5 mm long, oval, cream; achenes brown, narrow, 2.5-3 mm long; $n=19$ (Hardham 1989).

Local and common in sandy to gravelly places from the Death Valley region in the Mojave Desert of Inyo Co. south into the Sonoran Desert to Imperial and San Diego cos., California, and into northern Baja California Norte, México, then eastward across both deserts into Clark Co., Nevada, western Arizona probably as far as Maricopa Co. and northwestern Sonora, México, from $-230 \mathrm{ft}$ elev below sea level to $3000 \mathrm{feet} \mathrm{ft}$ elev; flowering from Feb-May.

Representative Specimens: MÉXICO. BAJA CALIFORNIA NORTE: NE side of Cocopa Mountains, 20 mi SE of Mexicali, 22 Apr 1949, Gentry 8702 (ARIZ, RSA, SBBG, US); Sierra de las Pintas, 24 Apr 1949, Gentry 8740 (ARIZ, RSA, US); W slope of the Sierra de los Cucapas, 1 Mar 1970, Moran 16777 (SD); 18 mi S of San Felipe, $18 \mathrm{Mar}$ 1960, Wiggins \& Wiggins 15818 (DS). SONORA: Sierra Extrana, SW part of the Pinacate Region, $17 \mathrm{Mar}$ 1970, Felger 19050 (ARIZ); 0.5 NE of the Sierra del Rosario, Gran Desierto, 11 Mar 1973, Felger et al. 20752 (ARIZ); $12 \mathrm{mi} \mathrm{NW}$ of Caborca, $10 \mathrm{Mar}$ 1936, Shreve 7540 (ARIZ, F, MEXU, MICH); $8.6 \mathrm{mi}$ NW of Caborca, 10 Mar 1936, Wiggins 8272 (ARIZ, DS, US). UNITED STATES. ARIZONA: Maricopa Co.: Sentienel, 24 Mar 1924, Orcutt 91 (US). Mohave Co.: near Fort Mojave, Apr 1884, Lemmon \& Lemmon s.n. (G, K, US); Davis Dam, Kathrine Campground, 11 Apr 1968, Pinkava et al. 12582 (BRY, ASU). Pima Co.: 15 mi S of Bates Well, 17 Mar 1945, Gould et al. 2982 (ARIZ, CAS, UC). Unknown Co.: without location data, 1876, Palmer 642 (G, ISC, MIN, NY, US); Colorado Valley, 1876, Palmer 642 (GH, LE, WU). Yuma Co.: Cabeza Prieta Game Range, along Camino El Diablo at the W edge of the Pinacate Lava Flow, $14.7 \mathrm{mi}$ E of Tule Well, 13 Mar 1983, Daniel \& Buttenwick 2688 (ASU, NY); hills near Dome, 6 Mar 1927, Harrison \& Belden 3615 (ARIZ, US); Telegraph Pass area E of Yuma, 25 Mar 1973, Higgins 6330 (ASU, NY); Cabeza Prieta Game Range, Pinacate Lava flow, 11 Apr 1978, Lehto \& Reeves 22525 (ASU, NY, OBI); Cabeza Prieta Game Range, 7 Apr 1979, Lehto et al. 23575 (ASU, BRY, NO, NY); 7 mi S of Wellton, 30 Mar 1941, Munz 16610 (DS, POM, WS, WTU); 0.4 mi W of Liguerta along 
U.S. Highway 80, 3 Feb 1973, Pinkava 10079 (ASU, NY, US). CALIFornta: Imperial Co.: 3 mi SW of Imperial Dam, 18 Mar 1941, Alexander \& Kellogg 1961 (DS, GH, UC, UTC); arroyo E of Laguna Palo Verde at NE base of Palo Verde Mountains, 4.5 mi S of Palo Verde, 18 Feb 1958, Bacigalupi \& Hutchison 6156 (JEPS, MIN, RM, UTC, WTU); $8 \mathrm{mi} \mathrm{N}$ of Winterhaven, $18 \mathrm{Mar}$ 1970, C.L. Hitchcock 25693 (COLO, DAO, G, ID, NY, OKL, OSC, RM, TEX, UC, UT, WTU); Picacho Road, 2 mi S of Picacho, 29 Mar 1973, Holmgren \& Holmgren 6548 (DAO, NEB, NY, OSC); Badlands S of Painted Gorge, 9 Mar 1986, Sanders et al. 6227 (HSC, OBI, UCR). Inyo Co.: Ashford Mill, Death Valley region, 22 Apr 1939, Gilman 3594 (POM); Salt Spring, Death Valley National Monument, 24 May 1915, Parish 10016 (DS, UC, USFS); Wingate Pass, S end of Panamint Range, 12 Mar 1937, Train s.n. (ARIZ, CHSC, COLO, DS, ILL, NEB, OSC). Kern Co.: Randsburg, 4 Apr 1935, Clokey \& Templeton 5669 (UC). Riverside Co.: $1 \mathrm{mi} \mathrm{N}$ of Riverside Mountains, $4 \mathrm{mi} \mathrm{S}$ of Vidal, $30 \mathrm{Mar}$ 1978, Faulkner 409 (BRY, UCR); Little Chuckwalla Mountains, 1.5 mi E of Graham Pass Road, 24 Mar 1983, Helmkamp 383-8 (HSC, UCR); 20 mi N of Ogilby along the road to Blythe, 20 Mar 1966, C.L. Hitchcock 24304 (DAV, DS, MARY, UC, WTU); Palen Valley, 15 mi NE of Desert Center, 23 Mar 1973, Holmgren et al. 6489 (ASU, CPH, ID, MONTU, NY, RENO, UT, UTC); Painted Canyon, near Mecca, 12 Apr 1927, Peirson 7175 (DS, POM, SBBG); E side of the Salton Sea at the mouth of Salt Creek, 24 Apr 1983, Sanders 3801 (COLO, UCR, UTC); W edge of Maria Mountains, $17 \mathrm{mi}$ from Blythe on the Rice Road, 29 Apr 1932, Wolf 3096 (DS, RSA, US, WTU). San Bernardino Co.: 4 mi from Parker on the Needles Road, 22 Apr 1928, Ferris 7205 (DS, NY); 1.1 mi E of Vidal Junction along the road to Parker and Earp, 19-25 Mar 1958, Ferris \& Bacigalupi 13272 (DS, JEPS, NY, RM, WS, WTU); 1 mi NE of Amboy, 7 May 1978, Henrickson 16864 (RSA, SD, UCR); $4.5 \mathrm{mi}$ S of Ibex Pass, 10 Mar 1973, Thorne et al. 42631 (NY, BM, RSA). San Diego Co.: Borrego Springs, 17 Apr 1895, Brandegee s.n. (NY, ORE); outside the E edge of Borrego State Park, 17 Mar 1962, Hitchcock \& Muhlick 22209 (F, NY, WTU); Arroyo Seco del Diablo, Carrizo Badlands, 9 Mar 1986, Jonsson \& Clemons 1338 (SD); Palo Verde Wash, Anza Borrego Desert State Park, 17 Mar 1985, Levin 1531 (SD, UCR); Colorado Desert, Apr 1889, Orcutt s.n. (B, MICH, MIN, MO, POM, US). NEvADA: Clark Co.: 0.5 mi SW of Davis Dam, Newberry Mountains, 25 Apr 1976, Holland 1064 (UNLV); Lake Mead, Callville Bay, 30 Apr 1983, K. Thorne 2417 (BRY, NESH). A total of 249 collections are known to us.

Chorizanthe corrugata (from the Latin corrugatus, wrinkled, ridged, alluding to the outer surface of the involucral tube) is one of the most distinctive species of the genus. In spite of the large number of collections we have seen, the full extent of its distribution needs to be confirmed by careful botanizing along the margins of its known range. The species is clearly restricted to the warm deserts of the Southwest so that its northern boundary is probably well established. The eastern and southern boundaries need work. We have seen only one collection from Maricopa Co., but as it was gathered by a collector notorious for his poor label data (Thomas 1969), it needs confirmation. We have seen a M.E. Jones collection of C. corrugata supposedly found at Rincon in Dona Ana Co., New Mexico at POM, yet it is dated 30 Apr 1884 when Jones was in Coconino Co., Arizona (Lenz 1986). In this instance we are assuming the location data are wrong but that the date is correct.

The narrow, transversely corrugate involucral tube is diagnostic. The thickened and spreading teeth atop the tube are similar to those found elsewhere in the sect. Acanthogonum but usually the teeth are unequally sized. A further indication that Chorizanthe corrugata is probably the evolutionary endpoint within the section is the reduction in stamen number from nine to six. However, it should be noted that Hardham has found in individual flowers four to eight stamens on occasion.

IVC. Chorizanthe R. Br. ex Benth. sect. Fragile Rev. \& Hardham, sect. nov.-TYPE: Chorizanthe brevicomu Torr. in Emory.

\section{A sect. Herbaceae caulibus fragilibus et staminibus tres differt.}

Plants spreading to erect; leaves oblanceolate to narrowly elliptic or spatulate; flowering stems slender, disarticulating at each node; bracts short awned; involucres cylindrical, slightly ventricose basally, 3-angled and 6-ribbed, without a scarious margin, the teeth short and uncinate; flowers greenish-white to white or pale yellowish-white, glabrous; stamens 3, at- 
tached faucially at near the top of the floral tube.

A bispecific section widely distributed in arid regions in western North America from southern Oregon and Idaho southward to northwestern México, and along the coast of western South America from extreme southern Perú south to central Chile, $-200 \mathrm{ft}$ below sea level to $9200(10,000) \mathrm{ft}$ elev; flowering from Oct-Jul.

\section{Key to the Species}

A. Involucral tube not ventricose basally, sparsely strigose; plants thinly pubescent; plants of North America. . 39. C. brevicornu

AA. Involucral tube ventricose basally, densely strigose; plants densely pubescent; plants of South America. 40. C. commissuralis

The morphological differences between the North and South American members of the sect. Fragile (from the Latin fragilis, easily broken, as to the disarticulating stems and branches) are minimal yet sufficient enough to unquestionably retain both at the species rank. Chorizanthe brevicomu is the most widely distributed taxon in North America, and C. commissuralis is the most widely distributed species of the genus in South America. It is likely that the latter is a recent introduction, and probably arrived in the late Pleistocene at about the same time that Oxytheca dendroidea did (Reveal 1978; Ertter 1980; Shields \& Reveal 1988).

\section{Chorizanthe brevicornu Torr. in Emory}

Spreading to erect, thinly pubescent annual herbs 0.5-3 (5) dm high and 0.5-3 dm across; leaves basal, oblanceolate to narrowly elliptic or spatulate, the blades (1) $1.5-3$ (4) cm long, 1-10 $\mathrm{mm}$ wide, pubescent on both surfaces but usually more so below than above, acute to rounded apically, tapering to a pubescent petiole $0.5-2 \mathrm{~cm}$ long; inflorescences cymose, the involucres solitary at each node; bracts 2 , opposite, similar to the basal leaves at the lower nodes only reduced $0.3-1(1.5) \mathrm{cm}$ long, 1-2.5 mm wide, becoming scalelike above, linear and acicular, short awned; involucres cylindric, 3-angled but 6-ribbed, green, the tube 3-5 mm long, thinly strigose, the teeth $0.4-1.2 \mathrm{~mm}$ long, spreading, divergent, the awn uncinate; flowers included, cylindric, $2-4 \mathrm{~mm}$ long, greenish-white to white or pale yellowish-white, glabrous, on short pedicels $0.1-0.3 \mathrm{~mm}$ long, the tepals monomorphic, linear to narrowly oblanceolate, acute, entire, united nearly three-quarters of their length; stamens 3 , slightly exserted, attached near the top of the floral tube, the filaments 2-3.5 mm long, white, glabrous, the anthers 0.3-0.4 mm long, oval, white to pale yellow; achenes dark brown, narrow, 3-4 mm long; $n=19-21,23$ (Hardham 1989).

Widespread and common in sandy to gravelly places in western North America from southern Idaho and southeastern Oregon south through eastern California, Nevada and western Utah to Arizona and northwestern México, -200 below sea level to $9200(10,000)$ ft elev; flowering from (Feb) Mar-Jul.

\section{Key to the Varieties}

A. Leaves oblanceolate to narrowly elliptic, 1-3 (5) mm wide; involucres distinctly ribbed; Mojave and Sonora deserts. 39a. var. brevicornu

AA. Leaves broadly oblanceolate to spatulate, $5-10 \mathrm{~mm}$ wide; involucres obscurely ribbed; Great Basin Desert and Snake River Plains. 39b. var. spathulata 
Goodman (1934) maintained the two varieties recognized here at the species rank. Rydberg (1912) described the northern expression using a name proposed by Small but not published by him. Rydberg (1917) and Abrams (1944) maintained the two as distinct species, but Munz $(1958,1959)$ and Hitchcock (1964) reduced Chorizanthe spathulata to an infraspecific rank under $C$. brevicornu where we prefer to maintain it.

39a. Chorizanthe brevicornu Torr. in Emory, Bot. Mex. Bound. 2: 177. 1858, var. brevicornu.-TYPE: on the Gila River, Arizona, Mar 1852, Parry s.n. (holotype: NY!).

Plants $0.5-3$ (5) dm high, 0.5-3 dm across; leaves oblanceolate to narrowly elliptic, the blades 1.5-3 (4) cm long, 1-3 (5) mm wide, acute, on rather indistinct petioles; involucres distinctly and prominently ribbed at maturity; $n=19-21,23$ (Hardham 1989).

Common in sandy soil on the Mojave and Sonora deserts of southeastern California from southern Mono Co. south to Baja California Norte, México, eastward across southern Nye and Clark cos., Nevada, to Arizona from Mohave to Yuma cos., eastward into Maricopa, Pima and Pinal cos. and in northwestern Sonora, México, from $-200 \mathrm{ft}$ below sea level to $7500 \mathrm{ft}$ elev; flowering from Feb-Jun (Jul).

Representative Specimens: MÉXICO. BAJA CALIFORNIA: NORTE: Cuesta de Jarhuai and vicinity, Laguna Seca, 6 Apr 1950, Gentry \& Cech 8999 (ARIZ, MICH, US); 2.5 mi S of Okies Landing, 2 Mar 1966, Moran 12387 (DS, RSA, SD); Arroyo Santa Catarina, 5 mi N of the mouth, 26 Mar 1970, Moran 16925 (ARIZ, ENCB, RSA, SD, UC); along the dirt road from Agua de Higuera to San Borja, E of Sierra El Principio, 21 Mar 1988, Reveal et al. 6666 (CAS, MARY); $5 \mathrm{mi}$ SW of S end of Bahía de San Luis Gonzaga, 24 Mar 1960, Wiggins \& Wiggins 15911 (ARIZ, DS, G, MICH, TEX). SONORA: $1.5 \mathrm{~km} \mathrm{~N}$ of Cerro Sombrero, SW part of the Pinacate Region, $12 \mathrm{Mar}$ 1970, Felger et al. 18896 (ARIZ); NE slope of Cerro del Pinacate at Red Cone Camp, 24 Apr 1985, Sanders \& Neisess 5651 (RSA, UCR); 41 mi SW of Sonoyta on road to Punta Penasca, 15 Mar 1936, Wiggins 8369 (DS, GH, MICH, UC, US). UNITED STATES. ARIZONA: Coconino Co.: above Bass Camp, Colorado River Mile 108, Grand Canyon National Park, 30 Apr 1979, Phillips et al. 79-275 (MNA). Gila Co.: flat N of Lower Ruin Ridge, Tonto National Monument, 5 May 1962, R.L. Burgess 432 (ASU); hills about Canyon Lake, Apache Trail, 3 May 1935, Nelson \& Nelson 1752 (G, GH, K, MO, NY, RM, UC). Graham Co.: 3 mi S of Pima, 9 Apr 1935, Maguire et al. 10616 (ARIZ, NY, UTC); near Fort Thomas, 17 Apr 1940, Pebbles 14586 (ARIZ, POM). Maricopa Co.: Papago Park, Tempe, 24 Mar 1932, Gillespie 5433 (DS, GH, NY, POM, UC, US); $2.2 \mathrm{mi}$ WNW of junction of Canal Service Road and the access road to the SE part of White Tanks Mountains Regional Park, 30 Mar 1968, Keil 3035 (ASU, CM, COLO); $2.5 \mathrm{mi} \mathrm{N}$ of McDowell Road Junction along Beeline Highway, 13 Mar 1960, Russell 11185 (MICH, SMU, WIS). Mohave Co.: Elbow Canyon, 6 May 1978, Coombs \& Bundy 2458 (ARIZ, BRY, ASC, ASU); $5 \mathrm{mi} \mathrm{S}$ of the Utah border along Highway 15, 21 Apr 1973, Higgins 6657 (CHSC, MSC, NY); 25 mi W of Kingman, 21 Mar 1968, C.L. Hitchcock 25619 (DAO, ID, UC, WTU); Fort Mojave, Apr 1884, Lemmon \& Lemmon s.n. (G, K, UC, US); Beaverdam River, 3 Apr 1934, Maguire et al. 4764 (GH, MO, RM, UC, UTC). Pima Co.: Ajo, NW of the mine pit, 17 Mar 1945, Gould et al. 2949 (ARIZ, CAS, NY, UC, US); Dripping Springs, Puerto Blanco Mountains, Organ Pine Cactus National Monument, 15 Apr 1952, Parker 7912 (ARIZ, MIN, RM, RSA, US, WS); near Tucson, 28 Apr 1883, Pringle s.n. (BR, E, F, G, GOET, K, MICH, MO, NY, PENN, PH, US, VT). Pinal Co.: 2.3 mi S of Chui Chuischu, Papago Indian Reservation, 6 Apr 1973, Lehto et al. 10622 (ASU, NY, US); $1 \mathrm{mi}$ above Coolidge Dam, small canyon on the S side of San Carlos Lake, 2 Apr 1935, Maguire 10411 (ARIZ, BRY, NY, UTC, WTU); 20 mi W of Casa Grande, 19 Mar 1935, Nelson \& Nelson 1218 (G, GH, K, MO, NY, PH, RM, SMU, UC, UTC, WTU). Yavapai Co.: Vulture Mountains, W of Wickenburg, 24 Mar 1979, P.C. Fischer 6058 (ARIZ, ASU); arroyo E of Interstate Highway 17 at the Rock Springs Exit, 15 May 1973, Spellenberg et al. 3107 (ASU, ENCB, NY). Yuma Co.: along the road to Martinez Lake, 4 Mar 1973, Halse \& Bird s.n. (ARIZ, OSC); $20 \mathrm{mi}$ Nof Dome, 24 Mar 1970, C.L. Hitchcock 25772 (DAO, ID, NY, OKL, TEX, WTU); along Gila River Road, $3 \mathrm{mi}$ NE of Wellton, 22 Mar 1933, Wiggins 6604 (DS, MICH, UC, US). CALIFORNIA: Imperial Co.: Signal Mountain, 2 Apr 1903, Abrams 3169 (DS, E, F, GH, K, MO, NY, PH, POM); Cargo Muchacho Mountains, large canyon at the SE end, $5.4 \mathrm{mi}$ NE of Interstate 8 off Sidewinder Road and Power-line Road, 6 Feb 1986, Boyd 1221 (HSC, NY, RSA, UCR); 5 mi NW of Coyote Wells, 12 Mar 1968, C.L. Hitchcock 25447 (COLO, DAO, DS, ID, NY, RM, UC, WTU); Jacumba Mountains, 3 air mi SW of Ocotillo, 27 Mar 1974, Holmgren \& Holmgren 7507 (ASU, COLO, CPH, DAO, NEB, NY, RENO, UT). Inyo Co.: between Shoshone and Silver Lake, 14 Jun 1930, Ferris 8007 (DS, MO, POM, UC); Death Valley, foot of the Grapevine Mountains near fork of Beatty Road, 16 Mar 
1973, Holmgren \& Holmgren 6326 (BRY, NY, UTC, WTU); Bishop Creek, 28 May 1958, J. T. Howell 33550 (CAS, DAV); Lava Crater Canyon, S of Wingate Wash, Panamint Range, 9 Mar 1937, Train s.n. (ARIZ, COLO, DS, ILL, NEB, OSC, RSA, US). Kern Co.: $7 \mathrm{mi} \mathrm{N}$ of Mojave along California Highway 14, 11 May 1977, R. Gustafson 168 (RSA, SBBG); N shore of Lake Isabella, 21 May 1962, Rose 62034 (MICH, OBI, RSA, TEX); El Paso Range, canyon N of El Paso Peak, 7 May 1962, Twisselmann 7056 (CAS, ENCB, SBBG). Los Angeles Co.: Palmdale, 14 Jun 1927, Hoffmann s.n. (SBBG); $0.5 \mathrm{mi} \mathrm{N}$ of Bob's Gap, N slope of Holcomb Ridge, 2.5 mi S of Llano, San Gabriel Mountains, 11 May 1973, Thorne 43467 (DS, NY, RSA). Mono Co.: Chalfant Valley, along U.S. Highway 6, $18.5 \mathrm{mi}$ S of Benton, 11 Jun 1976, Halse 1376 (OSC). Riverside Co.: between Cathedral City and Rancho Mirage, 20 May 1980, Erter \& Strachan 3474 (BRY, CAS, NY, WTU); Little Maria Mountains, 2.3 mi above Midland Post Office, 19-25 Mar 1958, Ferris \& Bacigalupi 13259 (DS, GH, JEPS, NY, RM, TEX, WTU); Cottonwood Spring, 30 Mar 1940, C.L. Hitchcock 5876 (DS, GH, MO, NY, RM, RSA, UC, UTC, WS, WTU); Palen Valley, 15 mi NE of Desert Center, 23 Mar 1973, Holmgren et al. 6492 (ASU, ID, MONTU, NY); 7-8 mi E of Mecca, Mecca Hills, 29 Mar 1963, Thorne 32388 (BM, DAO, RSA). San Bernardino Co.: $52 \mathrm{mi}$ W of Needles on road to Barstow, 5 Apr 1953, Carter \& Chisaki 3236 (ARIZ, BRY, COLO, DAO, DS, GH, ID, IDS, K, LL, NY, OKL, RM, RSA, SD, SMU, UC, US, UTC, WIS, WS, WTU); $13 \mathrm{mi}$ SW of Needles along U.S. Highway 66, 30 Apr 1958, Everett \& Balls 23045 (BM, DAV, RSA, W); along California Highway 247, $28.6 \mathrm{mi}$ SE of California Highway 18 in Lucerne Valley, 24 Apr 1982, McNeal 2613 (BRY, CPH, NY); Carlyle Mine, Pinto Mountains, E of Twenty-nine Palms, 22 Mar 1940, Munz 15738 (DS, ISC, POM, UC, UTC, WTU); 0.3 mi N of Interstate Highway 15 at the Razor Exit, 18 Mar 1988, Reveal \& Broome 6641 (CAS, MARY, MO, NY, RM, RSA). San Diego Co.: 2 mi NW of California Highway 78 on Narrows Road, Borrego Valley, 11 Mar 1962, Breedlove 1871 (DS, SBBG, UCSB); Borrego Spring, 9 Apr 1932, Epling \& Robison s.n. (DS, LA, ND, NO, NY, RSA, UC); junction of Borrego Springs Road with California Highway 78, 18 Mar 1964, Hitchcock \& Muhlick 23138 (F, HSC, UC, WS, WTU); Anza Borrego Desert State Park, Lower Borrego Valley, Split Mountain, 24 Mar 1974, Holmgren \& Holmgren 7487 (COLO, CPH, DAO, NEB, NY, RENO, UT); Colorado Desert, Apr 1889, Orcut s.n. (B, DAO, GH, MICH, MIN, MO, POM, US). San Luis Obispo Co.: Prefumo Canyon, 19 Jun 1978, Koutnik 524 (DAV); Polytechnic Canyon between Santa Margarita and San Luis Obispo, 1 May 1914, R. Reed s.n. (JEPS). NEvADA: Clark Co.: Kyle Canyon, Spring Mountains, 1 May 1937, Clokey 7495 (CAS, DS, NY, UC, UTC, WTU); W slope of McCullough Mountains, 16 mi W of Searchlight, 11 May 1964, Cronquist 9976 (BRY, NY, UTC); along the Virgin River, 3.5 air mi SW of Riverside Bridge, 5 May 1975, Holmgren \& Holmgren 7882 (BRY, ID, MONTU, NY, OSC, UTC, WTU); 15 mi E of Glendale, 19 May 1933, Maguire \& Blood 4366 (GH, MO, RM, UC, UTC); shore of Lake Mead near Boulder Dam, 2 May 1938, Train 1570 (ARIZ, GH, NY, RENO). Esmeralda Co.: Roosevelt Wells, 1 May 1977, Tiehm \& Williams 3093 (RENO) Lincoln Co.: Pahranagat Valley, 2 mi S of Alamo along U.S. Highway 93, 1.5 mi E of Buckhorn Ranch Road, 1 Jun 1980, Thorne \& Welsh 931 (BRY, NY). Nye Co.: Beatty Wash, 5 mi E of U.S. Highway 95, below N end of Yucca Mountain, 28 Apr 1970, Beatley \& Reveal 10243 (NTS, RSA); 4 mi SW of Beatty, 28 May 1945, Maguire \& Holmgren 25211 (DS, GH, NY, UC, US, UTC, WS, WTU); near the intersection of the road to Death Vally and road to Rhyolite, 1 Jul 1981, Williams \& Tiehm 81-98-2 (BRY, CAS, MO, NESH, UTC). UTAH: San Juan Co.: Hall's Crossing, 30 Apr 1966, Reveal 717 (G, MIN, NY, VT); Washington Co.: Diamond Valley, 19 May 1902, Goodding 881 (G, MO, RM, US); 3 mi N of St. George along U.S. Highway 18, 26 May 1983, Higgins \& Welsh 13431 (BRY, NY); St. George, 1875, Palmer s.n. (BM, F, LE, NY); near St. George, 1874, Parry 230 (GH, MO, NY); without location data, 1874, Parry 230 (CM, F, G, GH, K, MIN, NY, PH); S end of Initial Mesa, 20 Apr 1985, K. Thorne 3709 (BRY, NY, RM). A total of 905 collections are known to us.

The distribution of var. brevicornu (from the Latin brevis, short, cornu, horn, alluding to the short involucral teeth) does not appear to overlap that of var. spathulata. We have seen a few collections from outside the normal ranges but these were collections gathered by individuals who were not always exact with their label data. In Inyo Co., California, where the two varieties can be found, the var. brevicomu is found on the desert foothills at low elevations while the var. spathulata is found in the pinyon-juniper communities at higher elevations in the adjacent mountains.

39b. Chorizanthe brevicornu Torr. in Emory var. spathulata (Small ex Rydb.) C.L. Hitchc., Univ. Wash. Publ. Biol. 17(2): 103. 1964. Chorizanthe spathulata Small ex Rydb., Bull. Torrey Bot. Club 39: 309. 1912. Chorizanthe brevicomu Torr. in Emory subsp. spathulata (Small ex Rydb.) Munz, Aliso 4:89. 1958. - TyPE: Big Butte Station, Butte Co., Idaho, 23 Jun 1893, Palmer 230 (holotype: NY!; isotypes: US, WIS!). 
Plants 0.5-2 (3) dm high, 0.5-2 dm across; leaves broadly oblanceolate to broadly spatulate, 1-2 cm long, 5-10 mm wide, round, on distinct petioles; involucres rather obscurely ribbed at maturity; $n=19$ (Hardham 1989).

Common on mainly sandy to gravelly soil in the Great Basin of eastern California from northern Inyo Co. northward to southeastern Oregon in Lake, Malheur and Harney cos., eastward into western and northern Nevada and onto the Snake River Plains of southern Idaho as far east as Butte Co., from 2400-9200 $(10,000) \mathrm{ft}$ elev; flowering from (Apr) May-Jul.

Representative Specimens: UNITED STATES. CALIFornia: Inyo Co.: $1.5 \mathrm{mi} \mathrm{N}$ of New York Butte, Inyo Mountains, 17 Jul 1942, Alexander \& Kellogg 3114 (DS, GH, OKL, UC, UTC); Westgard Pass, 27 Jun 1930, Duran 2793 (ARIZ, BM, DAO, E, G, GH, ILL, MO, NY, SD, TEX, UC, UTC, VT); $0.6 \mathrm{mi}$ E of the entrance to the narrows, Westgard Pass, 8 Jul 1956, Everett \& Balls 21937 (BM, CAS, E, OSC, RSA, UT); Wild Rose Canyon, Panamint Range, 20 Jun 1931, Hoffmann 438 (CAS, SBBG); $1.4 \mathrm{mi}$ NW of Poleta Mine, 4 mi ESE of Laws, White Mountains, 11 Apr 1986, Morefield \& McCarty 3392 (BRY, HSC, MARY, MO, RSA, TEX, UCR); Thorndyke's, Wild Rose Canyon, Panamint Range, Death Valley National Monument, 7 Jul 1937, Munz 14862 (CAS, GH, MO, POM, UC); White Top Cabin, Cottonwood Mountains, Death Valley National Monument, 2 Jun 1982, P.M. Peterson 552 (ARIZ, BRY, RSA, UNLV); 2 mi NE of Willow Spring, Last Chance Mountains, 20 Jun 1955, Roos 6459 (DS, RSA, SD, UC, UCR); Bishop Creek, 5 mi SW of Bishop, 28 May 1958, Rose 58112 (BRY, CAS, DAO, E, G, GH, MIN, NY, RSA, SMU, UC, WS). Mono Co.: Cottonwood Springs Canyon, $1.6 \mathrm{mi}$ E of U.S. Highway 6, above ranch, 22 Apr 1978, C. Cowan 1157 (UCSB); near Mill Creek, NW side of Mono Lake, 4 Jul 1941, Hoover 5418 (UC, US); moraine E of Convict Lake, Convict Creek Basin, 9 Jun 1962, Major \& Bamberg 801 (CAS, COLO, DAV, UC); Owens River above Whiskey Creek, 8 Jul 1934, Peirson s.n. (JEPS, NO, POM); 1 mi N of California Highway 31 along the Bridgeport Canyon Road, 9 Jun 1962, Reveal \& Reveal 105 (CAS, NY, PH, RM, RSA, TEX, UC, UT, UTC, WTU). IDAHO: Ada Co.: $30 \mathrm{mi}$ S of Regina, 25 May 1943, Christ $51-39$ (ID). Blaine Co.: Picabo, 3 Jul 1916, Macbride \& Payson 3024 (CAS, CM, DS, E, GH, K, MO, NY, POM, RM, UC, US, WU). Butte Co.: along Big Lost River, $1.8 \mathrm{mi}$ SW of Idaho Highway 20-26 on T-12, Idaho National Engineering Laboratory, 24 Jun 1981, Cholewa 832 (ID); $5 \mathrm{mi}$ E of Arco, 31 May 1951, Christ 51-162 (ID, WTU); Big Butte, 28 May 1938, R.J. Davis 183 (IDS, NY). Elmore Co.: $3 \mathrm{mi} \mathrm{W}$ of Hammett, 24 Jun 1937, Christ \& Ward 7808 (NY, UC). Jefferson Co.: Idaho National Engineering Laboratory, 4r.5 mi ESE of Circular Butte, 16 Jun 1983, Henderson \& Cholewa 6541 (ID, NY, RM). Lincoln Co.: 6 mi N of Shoshone, 15 Jul 1944, Christ 14444 (NY); Shoshone, 18 Jul 1911, Nelson \& Macbride 1171 (CAN, DS, E, G, GH, MIN, MO, RM, WS). Owyhee Co.: Murphy, 4 Jul 1911, Macbride 1033 (CAN, DS, E, F, G, GH, MIN, MO, NY, POM, RM, SMU, UC, US, UTC, WS, WTU); $10 \mathrm{mi}$ S of Bruneau, 29 May 1946, Maguire \& Holmgren 26233 (GH, NY, UC, UTC). NEvADA: Churchill Co.: 0.8 mi NE of Bradys Hot Spring, 23 May 1978, Tiehm 4264 (MARY, MO, NY, RENO, UNLV); Hot Springs Mountain, 3.5 air mi SE of Desert Peak, 16 Jun 1983, Tiehm 7917 (CAS, NY, RSA, UTC). Esmeralda Co.: S end of Magruder Mountain, Silver Peak Range, 5 Jul 1945, Maguire \& Holmgren 25634 (DS, GH, NY, UC, US, UTC, WS, WTU); Magruder Mountains, $1.4 \mathrm{mi} \mathrm{N}$ of summit of Tule Canyon Road, 26 Jul 1983, Tiehm \& Nachlinger 8224 (BRY, IDS, NY, OSC, RSA, UTC). Eureka Co.: 2 mi N of Beowawe, 10 Jun 1941, A.H. Holmgren 1037 (DAO, NY, UTC). Humboldt Co.: 5 mi NW of Valmy, 21 Jun 1978, Mozingo \& Kartesz 78-80 (NESH). Lyon Co.: N edge of Bodie Hills along road from Sweetwater Flat to Mud Spring Valley, $0.7 \mathrm{mi}$ E of Sonoma, 26 Jun 1980, Messick 1082 (HSC). Mineral Co.: Hawthorne, 23 Jun 1882, M.E. Jones s.n. (BM, DS, NY, POM, UTC); upper Truman's Meadow, 12 Jul 1978, Williams \& Lott 78-210-15 (NY, UNLV). Nye Co.: saddle of D Road, S Kawich Range, 28 Jun 1969, Beatley 9234 (NTS, NY, RENO); $\mathrm{S}$ end of the Monitor Mountains, $2.3 \mathrm{mi} \mathrm{N}$ of U.S. Highway 6, 9 Jun 1976, Holmgren \& Holmgren 8159 (ASU, BRY, NY, RENO, RSA, UTC, WTU). Pershing Co.: NW of Lovelock, Trinity Mountains, 9 Jun 1943, Ripley \& Barneby 5631 (CAS). Washoe Co.: near Big Bend of the Truckee, May 1868, Watson 1044 (GH, NY, US). Oregon: Harney Co.: 16 mi S of Wagontire, 16 Jun 1937, M.E. Peck 19434 (ID, UC, WILLU, WTU). Lake Co.: Alkali Lake, 27 Jun 1961, Hardham 7982 (CAS, SBBG, UCSB); N end of Alkali Lake, 23 Jun 1941, M.E. Peck 20891 (NY, OSC, UC, WILLU). Malheur Co.: 15 mi SW of Rome, 15 Jun 1949, M.E. Peck 25715 (CAS, WILLU). A total of 137 collections are known to us.

The broad leaves which characterize this species are sometimes not present on individual specimens and the ability to distinguish the var. spathulata (from the Latin spathulatus resembling a broad, flat spoon, alluding to the shape of the leaves) from its more southern relative, var. brevicomu, can be troublesome. There are other features that are diagnostic, but these are sometimes difficult to use. The leaves of var. spathulata are distinctly petiolate 
whereas those of var. brevicomu are hardly much more than a slightly less expanded blade. Unfortunately, if the leaves have fallen away, the petioles are usually gone as well. The involucres of var. brevicomu are slightly shorter (generally 3-4 $\mathrm{mm}$ long versus typically 4-5 $\mathrm{mm}$ long) and more distinctly ribbed than those of var. spathulata. Even so, this is a general trend and not necessarily consistent throughout the range. Even the length of the involucre is highly variable and the full range $(3-5 \mathrm{~mm})$ can be found in scattered individuals of both varieties.

40. Chorizanthe commissuralis Rémy in Gay, Fl. Chil. 5: 287. 1851-1852. - TYPE: "Que se cria en los lugares secos de Guanta, Copiapo, cerca de Chanarcillo, etc.," but specimens without location data and exact date, Chile, Gay s.n. (lectotype to be selected and sought at P; duplicates of Gay specimens seen at F, GH, K!).

Spreading to erect, densely pubescent annual herbs $0.5-3 \mathrm{dm}$ high and $0.5-2 \mathrm{dm}$ across; leaves basal, oblanceolate to narrowly oblong, the blades $1-3 \mathrm{~cm}$ long, $1-3 \mathrm{~mm}$ wide, pubescent on both surfaces but usually more so below than above, acute apically, tapering to an indistinct pubescent, $0.5-1 \mathrm{~cm}$ long; inflorescences cymose, the involucres solitary at each node; bracts 2 , opposite, similar to the basal leaves at the lower nodes only reduced, $0.3-1 \mathrm{~cm}$ long, $1-2$ $\mathrm{mm}$ wide, becoming scalelike above, linear and acicular, short awned; involucres cylindric, 3-angled but 6-ribbed, green, the tube 3-4 mm long, strigose, the teeth 0.4-1 mm long, spreading, divergent, the awn uncinate; flowers included, cylindric, $2-4 \mathrm{~mm}$ long, greenish-white to white or pale yellowish-white, glabrous, on short pedicels $0.1-0.3 \mathrm{~mm}$ long, the tepals monomorphic, linear to narrowly oblanceolate, acute, entire, united nearly three-quarters of their length; stamens 3, slightly exserted, attached to the top of the floral tube, the filaments 2-3.5 $\mathrm{mm}$ long, white, glabrous, the anthers $0.3 \mathrm{~mm}$ long, oval, white to pale yellow; achenes dark brown, narrow, 3-4 $\mathrm{mm}$ long.

Widespread and locally common in sandy to gravelly places in southwestern South America from extreme southern Perú southward to central Chile, from 100-4000 ft elev, flowering from Oct-Jan.

Representative Specimens: CHILE. Aconcagua: San Felipe, without date, Hohenocker 816 (BM, GOET, LE); San Felipe, 1862, Philippi s.n. (G). Antofagasta: SE of Taltal, 25 Nov 1925, I.M. Johnston 5078 (BA, GH, K); 2 km S of Chincolco on road to Fundo "El Sobrante," 9 Nov 1970, Simon 291 (RSA); Taltal, Oct 1925, Werdermann 860 (CAS, B, BM, E, F, G, GH, K, MO, NY, Z); $10 \mathrm{~km}$ E of Taltal along the railroad, 13 Oct 1938, Worth \& Morrison 15809 (G, GH, K). Atacama: near Puerto de Chanaral on hills back of El Barquito, 28-29 Oct 1925, I.M. Johnston 4779 (GH); 8 km E of Copiapo, 20 Nov 1925, I.M. Johnston 4970 (GH, K); NW of Copiapo, 20 Nov 1925, I.M. Johnston 5031 (BA, GH); Chanarcillo, Sep 1885, Philippi s.n. (ISC). CopLAPO: Bandurrias, 1885, Geisse s.n. (GH). CoouimBo: Illapel, Feb 1912, Geisse s.n. (Z); Matancilla, near Illapel, Nov 1912, Geisse s.n. (Z); Vicuna, Cuesta del Churqui, 12 Oct 1940, Looser 4242 (GH); Los Chiches, 3 km W of Vicuna on road to La Serena, 27 Sep 1939, Wagenknecht 18443 (F, G, GH, MO, SMU, UC); $5 \mathrm{~km}$ from Vicuna along the road to La Serena, 3 Nov 1938, Worth \& Morrison 16349 (GH); Pajonales Pass, 10 Oct 1965, Zollner 4284 (L); valley of the Rio Seco los Choros, 21 Sep 1975, Zollner 8325 (MO). PERÚ. TARATA: between Tacna and Tarata on W side of pass, $1 \mathrm{~km}$ below Palquilla, 28 Nov 1964, Hutchison \& Wright 7191 (UC). A total of 32 collections are known to us.

The South American annual Chorizanthe commissuralis (from the Latin commissura, joint, juncture, alluding to the disarticulating stems and branches) was described a few years before its North American counterpart, but the exact year that Remy's (1851-1852) treatment of Polygonaceae was published in Gay's Historia fisica y política de Chile ... Botánica is uncertain (Stafleu \& Cowan 1976). Nonetheless, it was unequivocally published before Torrey (1858) proposed $C$. brevicomu, and should one wish to regard the two as the same species, then $C$. commissuralis would have priority. 
IVD. Chorizanthe R. Br. ex Benth. sect. Clastoscapa Rev. \& Hardham, sect. nov.-TYPE: Chorizanthe interposita Goodman.

A sect. Herbaceae caulibus fragilibus et staminibus novem differt.

Plants spreading to ascending; leaves linear; flowering stems slender, disarticulating at each node; bracts awned; involucres cylindrical, 3-angled and 3-ribbed, without a scarious margin, the teeth short and uncinate; flowers bicolored, the tube yellow, the lobes white to rose or copper, glabrous; stamens 9, attached at the base of the lobes at the top of the floral tube on a thickened rim.

A monospecific section widely distributed but rarely collected in Baja California, México, from 30-2300 ft elev; flowering from Jan-Apr.

The only species of the sect. Clastoscapa (from the Greek klastos, broken into pieces, and skapos, stem, alluding to the easily disarticulting stems and branches) was known to Goodman (1934) only from a single specimen yet he was able to conclude that Chorizanthe interposita was significant in the evolutionary history of the genus and its related genera. It was this specimen that led him to submerge Lastarriaea into Chorizanthe. Our evaluation of characters has shown that not only is $C$. interposita not related to Lastarriaea (that genus is actually much closer to C. brevicornu) but the species is well isolated from the rest of the taxa within the subg. Amphietes.

41. Chorizanthe interposita Goodman, Ann. Missouri Bot. Gard. 21: 32. 1934. - TYPE: San Quintín, Baja California Norte, México, 19 Apr 1886, Orcutt s.n. (holotype: MO!).

Spreading to ascending, thinly pubescent annual herbs $0.2-1 \mathrm{dm}$ high and $0.5-3 \mathrm{dm}$ across; leaves basal, linear, the blades $0.5-3 \mathrm{~cm}$ long, $0.2-0.8 \mathrm{~mm}$ wide, hirsute along the margins, acute apically, tapering to an indistinct petiole; inflorescences cymose, the involucres solitary at each node; bracts 3 , similar to the basal leaves only reduced, narrowly lanceolate, 0.4-1 $\mathrm{cm}$ long, 0.2-0.8 (1) $\mathrm{mm}$ wide, erect or nearly so, the awns $0.5-1 \mathrm{~mm}$ long; involucres cylindric, 3-angled but 3-ribbed, greenish or reddish, the tube 3-6 mm long, hirsute, the teeth 1.5-3 $\mathrm{mm}$ long, erect except for the spreading awn-tipped upper portion, the uncinate awns 0.5-1 $\mathrm{mm}$ long; flowers slightly exserted, cylindric, 3-4 mm long, bicolored, the tube yellow, the lobes white to pink, rose or copper, glabrous, on pedicels $0.5-1 \mathrm{~mm}$ long, the tepals monomorphic, narrowly oblanceolate, acute, entire, united more than three-quarters of their length; stamens 9, included, attached to the base of lobes at the top of the floral tube on a thickened rim, the filaments $0.5-0.6 \mathrm{~mm}$ long, white, glabrous, the anthers $0.2-0.3 \mathrm{~mm}$ long, oval, red to maroon; achenes brown, narrow, 3-4 mm long.

Widespread and probably common on sandy to gravelly soils in Baja California, México, along the coast and in the foothills and mountains from near Punta Colonet south into the Desierto el Vizcaíno, from $30-2300 \mathrm{ft}$ elev, flowering from Jan-May.

Representative Specimens: MÉXICO. BAJA CALIFORnIA NORTE: Ascension, 18 Apr 1889, Brandegee s.n. (DS, F, MIN, UC); 6 mi E of La Vuelta, 18 Mar 1966, Moran 12762 (MARY, RSA, SD); Arroyo Santa Catarina, 5 mi N of its mouth, 26 Mar 1970, Moran 16924 (ARIZ, ENCB, MO, RSA, SD, UC, US); N of Arroyo Seco, 8 mi from the mouth, 15 Jan 1973, Moran 19370 (ENCB, RSA, SD, UC); San Juan de Dios, 30 Apr 1973, Moran 20600 (GH, LL, MO, RSA, SD, UC, US, W); 2 mi N of San Antonio del Mar, 19 May 1975, Moran 22010 (ASU, CAS, ENCB, SD); 2 km W of Cerro Solo, 5 May 1979, Moran 27160 (MO, RSA, SD); Arroyo Léon, 5 mi N of Punta Prieta, 1 Feb 1973, Moran \& Reveal 19630 (SD, US); Arroyo el Socorro, 4 mi from its mouth, 25 Feb 1973, Moran \& Reveal 
20278 (ARIZ, SD, UC, US); $23.5 \mathrm{mi}$ E of México Highway 1 and $17.5 \mathrm{mi}$ W of Bahía de los Angeles, $21 \mathrm{Mar}$ 1988, Reveal et al. 6660 (BM, CAS, MARY, MO, NY, RM, RSA, US, WIS); $13.2 \mathrm{mi}$ W of San Borja, $9.4 \mathrm{mi}$ NW of México Highway 1 at Rosarito, 22 Mar 1988, Reveal et al. 6683 (BM, CAS, MARY, MICH, MO, NY, RM, RSA, US, WIS); Arroyo Rosarito, $0.5 \mathrm{mi}$ W of México Highway 1, $2.7 \mathrm{mi}$ SW of Rosarito, $22 \mathrm{Mar} 1988$, Reveal et al. 6695 (CAS, MARY, RSA); along México Highway 1, 5 mi S of Punta Prieta and $1.8 \mathrm{mi} \mathrm{N}$ of Rinconada, 23 Mar 1988, Reveal et al. 6706 (CAS, MARY, MO, NY, RM, RSA); along México Highway 1 near Puerto Chapala, 23 Mar 1988, Reveal et al. 6723 (CAS, MARY, RSA); 6.5 mi E of El Rosario, 24 Mar 1988, Reveal et al. 6741 (CAS, MARY, RSA); $5.6 \mathrm{mi} \mathrm{N}$ of El Consuelo and $3.8 \mathrm{mi} \mathrm{S}$ of Costa Rica, $24 \mathrm{Mar}$ 1988, Reveal et al. 6747 (CAS, MARY, MO, RSA); 5 mi S of Rosarito, 30 Mar 1977, G.L. Webster 21837 (DAV). Basa CaLfFonRIA SuR: 3 mi SE of San Andres, 5 Feb 1973, Moran \& Reveal 19794 (SD). A total of 47 collections are known to us.

We suspect that Chorizanthe interposita (from the Latin inter, between, positus, placed, alluding to the supposed intermediate position the species represented between Chorizanthe and Lastarriaea) is much more widespread and common than the above distribution and exsiccata would lead one to conclude. Of the 47 collections we have seen during this study, 38 were collected jointly or individually by Reid Moran or Reveal, both of whom were interested in documenting the distribution of the species. In the field the plants are a dark green or red and to the casual observer it appears to be past flowering. Even if one looks closely, the easily fragmenting stems and branches (when the plant is dry) only augment the supposition that the plant is dead. Still, even when the plant is in full flower and does not crumble, the rose to copper tinged tepals are difficult to detect so that the plant does not appear even to be in flower!

The easily broken stems and branches, coupled with the awn-tipped bracts and involucres, mean that the fragments can be easily dispersed by grazing animals and even human beings. We are uncertain if the lack of specimens prior to the Moran era of botanical explorations in Baja California was due to a failure to realize the plant was in flower or the range has expanded greatly as a result of domesticated animal grazing.

\section{ACKNOWLEDGMENTS}

We thank curators and staff of the following herbaria for loans or for arranging access to their collections during visits: A, ARIZ, ASC, ASU, B, BKL, BM, BR, BRY, CAN, CAS, CGE, CHSC, CM, COLO, CPH, CS, DAO, DAV, DS, E, ENCB, F, G, GB, GH, GOET, HSC, ID, IDS, ILL, IND, ISC, JEPS, K, KANS, KSC, L, LL, M, MARY, MICH, MIN, MNA, MO, MONTU, MPU, MSC, ND, ND-G, NEB, NESH, NMC, NO, NTS, NY, OBI, OKL, OKLA, ORE, OSC, OXF, P, PENN, PH, POM, RENO, RM, RSA, SBBG, SD, SFSU, TCD, TEX, UC, UCR, UCSB, UNLV, US, USFS, UT, UTC, VT, W, WILLU, WIS, WS, WTU, WU, and Z. Individuals interested in obtaining a printout of our available herbarium data may request a copy by contacting the senior author. Funding for field work has been made possible through a variety of sources. We wish to thank Dr. Edward E. Terrell for reviewing the manuscript. This is Scientific Article A-4944, Contribution 7987, Maryland Agricultural Experiment Station.

\section{LTTERATURE CITED}

Abrams, L. 1944. Illustrated flora of the Pacific States. Vol. 2. Stanford Univ. Press, Stanford.

Bentham, G. 1836. On the Eriogoneae, a tribe of the order Polygonaceae. Trans. Linn. Soc. London 17: 401-420. 1856. "Eriogoneae," pp. 5-28. In: A. de Candolle (edit.), Prodromus systematis naturalis regni vegetabilis. Vol. 14. Victor Masson, Paris.

Brandegee, T. S. 1889. A collection of plants from Baja California. Proc. Calif. Acad. Sci. II, 2: 117-215. 
Brizicky, G. K. 1969. Subgeneric and sectional names: Their starting points and early sources. Taxon 18: 643-660. Curran, K. 1885. Classification of the Eriogoneae as affected by some connecting forms. Bull. Calif. Acad. Sci. 1: 272-275.

Dammer, U. 1892. Polygonaceae. Nat. Pflanzenfam. 3(1a): 1-36.

Eastwood, A. 1903. New species of western plants. Bull. Torrey Bot. Club 30: 483-502. 1949. "In Portu Bodega." Leafl. W. Bot. 5: 162-167.

Ertter, B. J. 1980. A revision of the genus Oxytheca Nutt. (Polygonaceae). Brittonia 32: 70-102. 35: $28-29$.

\& A. Tiehm. 1983. Lectotypification of Chorizanthe watsonii (Polygonaceae: Eriogonoideae). Brittonia

Goodman, G. J. 1934. A revision of the North American species of the genus Chorizanthe. Ann. Missouri Bot.

Gard. 21: 1-102.

1939. A new species of Chorizanthe. Leafl. W. Bot. 2: 193-195.

1955. The genus Acanthogonum, tribe Eriogoneae. Leafl. W. Bot. 7: 234-235.

1957. The genus Centrostegia, tribe Eriogoneae. Leafl. W. Bot. 8: 125-128.

Greene, E. L. 1891. New and noteworthy species. X. Pittonia 2: 161-173.

Greuter, W. (edit.). 1988. International code of botanical nomenclature. Regnum Veget. 118: 1-328.

Hardham, C. B. 1964. A new California Chorizanthe. Leafl. W. Bot. 10: 95-96.

1989. Chromosome numbers of some annual species of Chorizanthe and related genera (Polygonaceae: Eriogonoideae). Phytologia 66: 89-94.

Heller, A. A. 1909-1914. Catalogue of North American plants north of Mexico. Edition 3. Published by the author, Lancaster.

Hitchcock, C. L. 1964. Chorizanthe. Univ. Wash. Publ. Biol. 17(2): 103-104.

Hoffmann, R. 1932. Notes on the flora of the channel islands off Santa Barbara, California. Bull. S. Calif. Acad. Sci. 31: 46-60.

Hooker, J. D. 1880. "Polygonaceae," pp. 88-105. In: G. Bentham \& J. D. Hooker, Genera plantarum. Vol. 3. L. Reeves and Co., London.

Hoover, R. F. 1966. Miscellaneous new names for California plants. Leafl. W. Bot. 10: 337-350.

Howell, J. T. 1937. A Russian collection of California plants. Leafl. W. Bot. 2: 17-20.

Jepson, W. L. 1913. Polygonaceae. Fl. Calif. 4: 376-428.

1923. Manual of the flowering plants of California. Student Store, Berkeley.

Lenz, L. W. 1986. Marcus E. Jones. Rancho Santa Ana Botanic Garden, Claremont, California.

McKelvey, S. D. 1955. Botanical explorations in the Trans-Mississippi West, 1790-1850. Arnold Arboretum, Jamaica Plain, Massachusetts.

Munz, P. A. 1958. California miscellany. IV. Aliso 4: 87-100. 1959. A California flora. Univ. California Press, Berkeley. 1968. Supplement to A California Flora. Univ. California Press, Berkeley. 1974. A flora of Southern California. Univ. California Press, Berkeley.

Nuttall, T. 1848 . Descriptions of plants collected by Mr. William Gambel in the Rocky Mountains and Upper California. Proc. Acad. Nat. Sci. Philadelphia 4: 7-26.

Parry, C. C. 1884. Chorizanthe R. Brown. Revision of the genus, and rearrangement of the annual species-with one exception, all North American. Proc. Davenport Acad. Nat. Sci. 4: 45-63. 1885. Notes on Chorizanthe lastarrica, Parry. W.-Amer. Sci. 1: 29-31.

1889. Chorizanthe, R. Brown. Review of certain species heretofore improperly characterized or wrongly referred; with two new species. Proc. Davenport Acad. Nat. Sci. 5: 174-184.

Raven, P. H. 1963. Amphitropical relationships in the floras of North and South America. Quart. Rev. Biol. 38: 151-177.

Rémy, J. 1851-1852. "Poligoneas," 263-293. In: C. Gay, Historia física y política de Chile ... Botánica. Vol 5, part 3. E. Thunot y Ca., Paris.

Reveal, J. L. 1968. "The subgeneric concept in Eriogonum (Polygonaceae)," pp. 229-249. In: J. E. Gunckel (edit.), Current topics in plant science. Academic Press, New York. $169-190$. 1978. Distribution and phylogeny of Eriogonoideae (Polygonaceae). Great Basin Naturalist Mem. 2:

1989a. A new species of Chorizanthe (Polygonaceae) from Baja California Norte, México. Phytologia 66: $95-97$. 66: $199-220$.

1989b. Notes on selected genera related to Chorizanthe (Polygonaceae: Eriogonoideae). Phytologia 
\& C. B. Hardham. 1989. Three new monospecific genera of Polygonaceae subfamily Eriogonoideae from California. Phytologia 66: 83-88. $227-235$

\& R. Moran. 1977. Miscellaneous chromosome counts of western American plants-IV. Madroño 24:

Rose, J. N. 1890. Notes on some western plants. Bot. Gaz. 15: 63-66.

Rydberg, P. A. 1912. Studies on the Rocky Mountain flora. XVII. Bull. Torrey Bot. Club 39: 301-328. 1917. Flora of the Rocky Mountains and adjacent plains. Published by the author, New York.

Shields, O. \& J. L. Reveal. 1988. Sequential evolution of Euphilotes (Lycaenidae: Scolitantidini) on their plant host Eriogonum (Polygonaceae: Eriogonoideae). Biol. J. Linn. Soc. 33: 51-93.

Stafleu, F. A. (edit.) 1978. International code of botanical nomenclature. Regnum Veget. 97: 1-457.

\& R. S. Cowan. 1986. Taxonomic literature-II. Sti-Vuy. Regnum Veget. 115: 1-926.

Stokes, S. G. 1900. A new Chorizanthe from Lower California. Zoe 5: 60.

Takhktajan, A. 1976. "Neoteny and the origin of flowering plants," pp. 207-219. In: C. Beck (edit.), Origin and early evolution of angiosperms. Columbia Univ. Press, New York.

Thomas, J. H. 1969. Botanical explorations in Washington, Oregon, California and adjacent regions. Huntia 3: 5-62.

Torrey, J. 1857a. "Botanical report," pp. 1-28. In: J. G. Parke, Explorations and surveys for a railroad from the Mississippi River to the Pacific Ocean. Vol. 7, part 3. U.S. Government Printing Office, Washington, D.C. 1857b. "Report on the botany of the expedition," pp. 59-182. In: A. W. Whipple, Explorations and surveys for a railroad from the Mississippi River to the Pacific Ocean. Vol. 4, part 5. U.S. Government Printing Office, Washington, D.C.

1857c. "Descriptions of plants collected along the route," pp. 359-370. In: W. P. Blake, Explorations and surveys for a railroad from the Mississippi River to the Pacific Ocean. Vol. 5, part 2. U.S. Government Printing Office, Washington, D.C.

1858. "Botany of the boundary," pp. 1-78. In: W. H. Emory, Report on the United States and Mexican boundary survey. Vol. 2. A. O. P. Nicholson, Washington, D.C.

\& A. Gray. 1870. A revision of the Eriogoneae. Proc. Amer. Acad. Arts 8: 146-200.

Voss, E. G. (edit.) 1983. International code of botanical nomenclature. Regnum Veget. 111: 1-472.

Watson, S. 1877. Descriptions of new species of plants, with revisions of Lychnis, Eriogonum and Chorizanthe. Proc.

Amer. Acad. Arts 12: 246-278.

1880. Geological Survey of California ... Botany. Vol. 2. John Wilson and Son, Cambridge.

1882. Contributions to American botany. Proc. Amer. Acad. Arts 17: 316-382.

Wiggins, I. L. 1940. New and poorly known species of plants from the Sonoran Desert. Contr. Dudley Herb. 3: 65-84. . 1980. Flora of Baja California. Stanford Univ. Press, Stanford.

\section{INDEX TO NAMES}

Acanthogonum, 100, 179

corrugatum, 187

polygonoides, 177

longispinum, 178

rigidum, 180

Chorizanthe, 100

Acanthogonum, 175, 179

Amphietes, 113

andersonii, 122

angustifolia, 126

eastwoodae, 126

Anisogonum, 115

Ansata, 183

biloba, 137

biloba, 138

immemora, 138

blakleyi, 141

brevicornu, 189

brevicornu, 190

spathulata, 191

breweri, 163

Campylosperma, 179 chaetophora, 151

Chorizanthe, 108

Chorizanthella, 186

chrysacantha, 155

compacta, 155

Clastoscapa, 194

clevelandii, 144

commissuralis, 193

Chorizanthopsis, 108

corrugata, 187

cuspidata, 127

cuspidata, 128

marginata, 128

villosa, 129

diffusa, 122

nivea, 122

discolor, 155

douglasii, 118

albens, 124

hartwegii, 130

Eriogonella, 110

Eriogonellopsis, 115
Euchorizanthe, 108, 115

Exolophyta, 182

fernandina, 149

fimbriata, 171

fimbriata, 172

laciniata, 174

flava, 170

Flavae, 166

Fragile, 188

Herbaceae, 115

howellii, 131

inequalis, 149

insularis, 164

interposita, 194

jonesiana, 151

laciniata, 174

Legnota, 116

leptotheca, 158

membranacea, 111

mutabilis, 168

nivea, 122

nortonii, 118 
nudicaulis, 155

obovata, 140

prostrata, 140

orcuttiana, 183

palmeri, 135

biloba, 138

ventricosa, 139

Parryanae, 147

parryi, 147

fernandina, 149

parryi, 148

Parvatia, 176

Petasata, 134

polygonoides, 176

longispina, 178

polygonoides, 177

procumbens, 151

albiflora, 151

mexicana, 151

Procumbentes, 150

pulchella, 169 pungens, 123

cuspidata, 128

diffusa, 122

hartwegiana, 125

hartwegii, 130

nivea, 122

pungens, 124

robusta, 130

Pungentes, 120

Quintaria, 108

rectispina, 143

rigida, 180

robusta, 130

rosulenta, 168

spathulata, 191

spinosa, 109

Staticoideae, 154

staticoides, 155

bracteata, 155

brevispina, 155

chrysacantha, 155 elata, 155

latiloba, 155

nudicaulis, 155

stellulata, 117

Suffrutices, 108

turbinata, 167

uncinata, 151

uniaristata, 146

Uniaristatae, 144

valida, 132

vaseyi, 170

ventricosa, 139

villosa, 129

watsonii, 184

wheeleri, 164

xantii, 160

leucotheca, 162

xantii, 161

Eriogonella, 100, 110

spinosa, 109 


\section{$2 \mathrm{BHL}$ Biodiversity Heritage Library}

Hardham, C B and Reveal, James L. 1989. "A revision of the annual species of Chorizanthe (Polygonaceae: Eriogonoideae)." Phytologia 66, 98-198. https://doi.org/10.5962/bhl.part.10123.

View This Item Online: $\underline{\text { https://www.biodiversitylibrary.org/item/47410 }}$

DOI: https://doi.org/10.5962/bhl.part.10123

Permalink: https://www.biodiversitylibrary.org/partpdf/10123

\section{Holding Institution}

New York Botanical Garden, LuEsther T. Mertz Library

\section{Sponsored by}

The LuEsther T Mertz Library, the New York Botanical Garden

\section{Copyright \& Reuse}

Copyright Status: In copyright. Digitized with the permission of the rights holder.

Rights Holder: Phytologia

License: http://creativecommons.org/licenses/by-nc-sa/3.0/

Rights: https://biodiversitylibrary.org/permissions

This document was created from content at the Biodiversity Heritage Library, the world's largest open access digital library for biodiversity literature and archives. Visit BHL at https://www.biodiversitylibrary.org. 